Universidade de São Paulo

Faculdade de Filosofia, Letras e Ciências Humanas

Departamento de Sociologia

Programa de Pós-Graduação em Sociologia

\title{
A Teoria Crítica e Max Weber
}

Caio Eduardo Teixeira Vasconcellos

Tese apresentada ao Programa de Pós-Graduação em Sociologia do departamento de Sociologia da Faculdade de Filosofia, Letras e Ciências Humanas, como requisito à obtenção do grau de doutor, sob orientação do Prof. Dr. Ricardo Musse.

Versão corrigida em outubro de 2014

São Paulo

2014 
Universidade de São Paulo

Faculdade de Filosofia, Letras e Ciências Humanas

Departamento de Sociologia

Programa de Pós-Graduação em Sociologia

A Teoria Crítica e Max Weber 
Para o Tales, o Iuri e o Gabriel. 


\section{Agradecimentos}

Ao professor Ricardo Musse, meu orientador desde antes do mestrado, por inumeráveis e decisivos motivos. Aos professores Marcos Alvarez e Antonio Flávio Pierucci pelas sugestões absolutamente certeiras para os rumos desta pesquisa. Ao professor Alex Demirovic, meu orientador nos tempos de Alemanha. Aos funcionários do Departamento de Sociologia da Universidade de São Paulo - em especial, ao Vicente.

Por etapas, aos meus queridos amigos. Ao pessoal do "Weber clandestino” da São Francisco - em especial, ao Danilo, Flávio, Chico, à Bianca, Bruna e Rita (estas duas últimas, reprovadas por falta). Da conexão Marburg-Berlin-Osasco: ao Arthur, Carise, Felipe, ao maduro Gabriel, Júlia, Krista, Luís, Mariana e ao Victor. Ao Maurício, com destaque; ao Emanuel, com maior ainda (embora ele também merecesse ficar de fora da lista...).

Aos mais velhos Bruno, Carlos, Cronópio, Eduardo, Fernando, Fábio, Ilan, Rica, Ugo e Vladimir; à Anouch, Bruna, Gabi, Luana, Maria, Natália, Patrícias e, em especial, à Rafaela - que o feliz acaso tornado cotidiano se estenda para além de todo e qualquer prazo!

Aos meus pais, às minhas irmãs, aos meus cunhados e, finalmente, aos meus sobrinhos!

Esta pesquisa foi financiada por recursos da Capes, do Cnpq, do DAAD e da Fapesp. 


\section{Resumo:}

O objetivo desta pesquisa é interpretar as relações entre os autores da primeira geração da teoria crítica - Max Horkheimer, Theodor Adorno e Herbert Marcuse - com a sociologia de Max Weber. Usualmente, elas são analisadas visando destacar as suas semelhanças e as suas continuidades. Todavia, para reconstruir a maneira pela qual esses frankfurtianos incorporaram certa temática weberiana, será necessário ressaltar as suas divergências e suas rupturas não apenas dos frankfurtianos com Weber, mas inclusive entre eles mesmos. Mais que uma simples operação de transposição conceitual, a apropriação crítica ao pensamento de Weber é ainda um eixo em torno do qual se pode interpretar aspectos particulares da teoria social de Horkheimer, de Adorno e de Marcuse.

Palavras-chave: Teoria crítica; Max Weber; Max Horkheimer; Theodor Adorno; Herbert Marcuse.

\section{Abstract:}

Keys-word: Critical theory; Max Weber; Max Horkheimer, Theodor Adorno; Herbert Marcuse.

The main aim of this research is to study the relationship between the authors of the first generation of critical theory - Max Horkheimer, Theodor Adorno and Herbert Marcuse - with the sociology of Max Weber. Usually, they are analyzed in order to highlight their similarities and their continuities. However, to reconstruct the way in which these frankfurtians incorporated certain Weberian theme, is also necessary to highlight their differences and their breaks not only the frankfurtians with Weber, but even among themselves. More than a simple conceptual transposition, critical to the thought of Weber ownership is still an axis around which to interpret particular aspects of social theory Horkheimer, Adorno and Marcuse. 
"Todo abismo é navegável a barquinhos de papel"

Guimarães Rosa 
Índice

Introdução.

Contenda sobre meios e fins. Horkheimer e Weber na década de 1930.

A teoria crítica versus uma ciência empírica.

A racionalidade ocidental ante novos interesses. 35

Do sofrimento imerecido...

... à uma nova fraternidade? $\quad 66$

O desencantamento do mundo como mito. Crítica à dominação da natureza em cena. $\quad 77$

Das portas do capitalismo moderno ao preanimismo. 82

$\begin{array}{ll}\text { Mundo desencantado? } & 109\end{array}$

O antissemitismo em seus aspectos mágicos e religiosos. 127

Apêndice - A razão e seus descalabros. Weber e a Eclipse da razão. 142

$\begin{array}{ll}\text { A dialética negativa de Adorno em Weber. } & 159\end{array}$

$\begin{array}{ll}\text { Crítica ao positivismo. } & 164\end{array}$

As constelações e os tipos ideais. 172

$\begin{array}{ll}\text { Críticas ao valor. } & 189\end{array}$

Weber e a ratio em sua irracionalidade. Uma interpretação de Marcuse. 195

$\begin{array}{ll}\text { A sociedade afluente e seus entraves. } & 199\end{array}$

“Espírito coagulado” e suas cicatrizes. 208

Capitalismo moderno e sua política. 
Referências bibliográficas. 


\section{Introdução.}

Desde o aparecimento do termo com Maurice Merleau-Ponty, o conceito de marxismo weberiano sempre se distinguiu de uma simples historiografia das ideias. O uso desse conceito aspirava não apenas apontar para mudanças teóricas e conceituais no interior do marxismo, mas ao mesmo tempo interpretar processos históricos e sociais mais amplos. Nesse sentido, a incorporação de certos temas weberianos entre autores marxistas indicaria uma transformação radical das possibilidades interpretativas e políticas do marxismo no século XX.

A esse respeito, de acordo com Merleau-Ponty, o pensamento social europeu do início do século passado encontrava-se em uma situação de crise que espelhava antinomias para as quais se enveredava a sociedade moderna. Max Weber, em quem o entendimento aprendeu a duvidar de si, escancarou os impasses das sociedades modernas ao dissolver a ingênua unidade imediata entre o pensamento e a ação, e compreender que a história é o lugar natural da violência e do conflito. A partir de então, o marxismo só foi rigoroso e consequente quando absorveu em suas formulações uma teoria da compreensão histórica, isto é, no momento em que abandonou as ilusões de um desenlace necessário do saber absoluto, transformando-se uma reflexão sobre as vicissitudes que marcam a relação entre a representação ideal da sociedade e a sua história real. Em As aventuras

\section{da dialética:}

Os conjuntos inteligíveis da história não rompem suas amarras com a contingência, e o movimento pelo qual ela se volta sobre si mesma para tentar apreender-se, dominar-se, fazer-se razão tampouco tem qualquer garantia. A história comporta fatos dialéticos, significações esboçadas, não é um raciocínio ordenado; como um interlocutor desatento, deixa o debate se desviar, esquece no meio do caminho os dados do problema. As épocas históricas se deixam agrupar em torno de uma interrogação sobre a possibilidade do homem, para a qual cada uma dá a fórmula, e não em torno de uma solução cuja manifestação seria a história. ${ }^{1}$

Os autores da chamada Escola de Frankfurt assumem um papel de destaque nessas transformações. Jürgen Habermas afirma que durante o período de crítica à razão instrumental, Theodor Adorno e Max Horkheimer perceberam a necessidade de buscar em um nível mais

1 Merleau-Ponty, Maurice. As aventuras da dialética; p. 22-23; 
profundo os fundamentos da crítica à reificação e de ampliar a razão instrumental convertendo-a em uma categoria do processo histórico universal da civilização ocidental². Via Georg Lukács - que teria abarcado o processo de racionalização weberiano na categoria marxista da coisificação - a apropriação da sociologia de Weber pelos autores da primeira geração da Escola de Frankfurt foi o ponto de partida conceitual para a realização dessa tarefa.

Seja por meio da equivalência entre a fórmula adorniana do mundo administrado e a metáfora weberiana da rija crosta de aço, seja pela ampliação do tema da racionalização para além do contexto histórico do nascimento do sistema econômico capitalista, a convergência teórica entre esses pensadores teria desencadeado um processo de redefinição profunda dos pressupostos conceituais até então vigentes entre os autores da teoria crítica. Em Teoria do agir comunicativo:

Horkheimer e Adorno estão diante do seguinte problema: por um lado, combatem a posição de Lukács para quem a racionalização aparentemente plena do mundo encontra seu limite ao deparar com o caráter formal de sua própria racionalidade - seja por via empírica, mediante uma referência às formas de manifestação de uma reificação penetrante da cultura e da natureza interior; seja por via teórica, mediante a comprovação de que também o idealismo objetivo cultivado pelo marxismo de matriz hegeliano simplesmente dá continuidade à linha do pensamento identitário, reproduzindo em si mesmo a estrutura da consciência reificada. Por outro lado, Horkheimer e Adorno radicalizam a crítica de Lukács à reificação. Consideram não apenas "aparente" a racionalização plena do mundo, e portanto necessitam de um universo conceitual que lhes permita denunciar o todo - nada menos do que isso - como sendo o inverídico. ${ }^{3}$

Dessa forma, pode-se afirmar que as transformações no interior do enfoque teórico desses frankfurtianos, desencadeadas a partir da publicação da Dialética do Esclarecimento (doravante DE), são acompanhadas pela presença marcante de preocupações compartilhadas, em larga medida, com a sociologia de Weber. Isto é, questões acerca do papel da ciência e da formalização da razão, dos rumos da civilização ocidental e da racionalidade moderna, da burocratização da sociedade e das relações que se estabelecem entre os indivíduos e a sociedade, etc., configuram os principais interesses desses autores.

Segundo Seyla Benhabib essa incorporação da temática weberiana pela teoria crítica deve ser avaliada sob o signo de uma aporia teórica. A partir da década de 1940, os frankfurtianos

2 Habermas, Jürgen. Teoria do agir comuncativo; p. 641.

3 Ibidem; p. 650. 
passariam a descrever as sociedades modernas no capitalismo pós-liberal como um arranjo completamente administrado, uma espécie de sociedade unidimensional no qual já não mais haveria espaço para qualquer tipo de contradição estrutural, onde não haveria nenhuma dinâmica histórica intrínseca e, por fim, nenhuma possibilidade objetiva de emergência de outra configuração social. Esse desenlace se expressaria no surgimento de um novo paradigma de crítica. Em termos gerais, ele é descrito da seguinte maneira: a crítica imanente se converteria em dialética negativa, a crítica desfetichizante em crítica da cultura e, por fim, a crítica como diagnóstico de crise se reduziria a uma filosofia retrospectiva da história, com propósitos utópicos. Por outros termos, o que Benhabib tenta demonstrar é que o pensamento dos frankfurtianos, malgrado suas intenções, teria se descolado do movimento geral das sociedades. Contrariamente ao que se realizara nos anos do materialismo interdisciplinar, a teoria crítica enveredava-se em aporias que bloqueavam a possibilidade de uma teoria social. Em "A crítica à razão instrumental":

Essa “critica totalizante” desencadeou uma ruptura radical com a concepção de teoria crítica de 1937. A história da relação da humanidade com a natureza não revela uma dinâmica emancipatória, como Marx gostaria que acreditássemos. O desenvolvimento das forças produtivas, o domínio crescente da humanidade sobre a natureza, não é acompanhado por uma diminuição da dominação interpessoal; ao contrário, quanto mais racionalizada é a dominação da natureza mais sofisticada e difícil de reconhecer torna-se a dominação social. ${ }^{4}$

Entretanto, ainda que o diálogo seja evidente, uma confrontação mais detida com os textos dos frankfurtianos parece desautorizar qualquer aproximação imediata. Pode-se depreender daí, portanto, que, de um lado, embora alguns aspectos da teoria social de Weber sejam incorporados pelos frankfurtianos, isso não se dá como uma mera transposição conceitual, mas de maneira crítica. E, consequentemente, a própria compreensão acerca da modernidade capitalista mostra indícios de diferir entre Weber e os frankfurtianos ${ }^{5}$. De outro, é possível perceber ainda divergências existentes

4 Benhabib, Seyla. “A crítica à razão instrumental”; p. 81.

5 A esse respeito, Martin Jay afirma: “Contudo, o que Weber denominava 'racionalização' era muito diferente do que pretendia dizer o Institut. Em síntese, para Weber, a autoridade racional-legal significava a obediência a um sistema de regras coerente e abstrato, estabelecido mediante acordo ou imposição e implementado por uma equipe burocrática. A obrigação se dava para com as leis, não os homens. A burocracia compunha-se de funcionários escolhidos por procedimentos regulares, com base na competência administrativa. A calculabilidade, a eficiência e a impessoalidade eram as características básicas desse padrão de autoridade”. Jay, Martin. A imaginação dialética; p. 171. Ainda segundo Jay, a hipostasia da relação entre "meios e fins" e a crença na possibilidade de uma ciência social "isenta de valores" seriam outras das "teses” weberianas com as quais os "frankfurtianos" se distanciavam. 
entre a crítica aos conceitos weberianos realizados por Horkheimer, das formuladas por Adorno e das feitas por Marcuse. A partir disso, pode-se reconstruir um rico debate teórico e conceitual de maneira mais atenta às nuances que marcam as relações que esses autores estabelecem com Weber. Mais do que simples sutilezas conceituais, pode-se analisar essas discrepâncias como divergências que se erigem a partir de formas distintas de compreender e de criticar as sociedades modernas. Isto porque, cada qual a seu modo, esses autores procuraram articular suas críticas e suas considerações a respeito da sociologia weberiana à uma reflexão que não perde de vista as vicissitudes e a especificidade histórica das sociedades capitalistas pós-liberais.

Posto isso, esta tese de doutorado se estrutura da seguinte maneira. No primeiro capítulo, o objetivo será discutir a apropriação de certas categorias weberianas por Horkheimer durante os anos de 1930. Nesse sentido, inicio minhas discussões a partir da reconstrução da crítica metodológica do frankfurtiano a Weber. De acordo com Horkheimer, sobretudo por seu conceito de possibilidade objetiva e por suas concepções a respeito da neutralidade axiológica nas ciências sociais, o pensamento de Weber se classificaria entre as correntes da chamada teoria tradicional. Ao associar a possibilidade de imputação causal no âmbito das ciências da cultura ao grau de racionalização das ações e das relações sociais, o sociólogo de Heidelberg não conseguiria ultrapassar as contradições peculiares às sociedades capitalistas.

No polo oposto, a teoria crítica identifica nesse tipo específico de racionalização a manifestação própria de um sujeito ilegítimo, qual seja, a sociedade moderna. Os critérios formais de racionalidade teriam sido forjados em conformidade com os imperativos heteronômicos ditados pela totalidade social. Transformados em uma espécie de segunda natureza, tais elementos atuariam vigorosamente para a conservação da ordem social existente. Todavia, ao prescindir de uma 
organização substancialmente racional do sistema de produção e distribuição da riqueza social, as sociedades modernas permaneceriam presas às incoerências ocasionadas pelo influxo de forças socioeconômicas ainda indômitas.

De acordo com Horkheimer, recuperar o ímpeto progressista da razão e da cultura seria a aposta para superar tais entraves e construir uma sociedade mais humana. Para tanto, mostra-se central a crítica ao moderno conceito de autoridade. Mais uma vez, o diálogo com Weber é mobilizado. O interesse do frankfurtiano volta-se, sobretudo, para uma discussão com a sua noção de sofrimento imerecido e com as suas reflexões a respeito da falta de sentido das produções socioculturais modernas.

No segundo capítulo, o alvo será perscrutar as relações da DE e de Eclipse da Razão com o pensamento de Weber. A intenção principal seria analisar os motivos que levaram Adorno e Horkheimer a privilegiar uma discussão distinta da realizada na década anterior como sugerir alguns elementos das diferenças entre esses dois autores no tocante à sociologia weberiana. Tentar interpretar a maneira pela qual algumas dessas transformações teóricas repercutiram no diálogo com a sociologia weberiana me pareceu um caminho profícuo. As mudanças de enfoque sobre determinados conceitos e uma abordagem distinta a certos aspectos do pensamento weberiano contribuem tanto para a análise da relação com Weber quanto para a compreensão do próprio pensamento dos frankfurtianos.

Dessa forma, a discussão principal gira em torno da relação dos frankfurtianos com o conceito weberiano de desencantamento do mundo em DE. Esse processo histórico-religioso de longuíssima duração é identificado com o próprio projeto do esclarecimento. Seja pelas diferentes análises de sua atuação e de seus resultados no passado mágico-religioso da civilização ocidental, seja pelo diagnóstico de um novo processo de reencantamento fetichista do mundo social moderno, ou ainda nas tentativas dos frankfurtianos em interpretar os mecanismos de funcionamento do antissemitismo, esse conceito de Weber é examinado a partir de uma perspectiva dialética. A 
questão não seria somente reexaminar os momentos-chave da formação da moderna civilização europeia, mas sobretudo revelar a sua irracionalidade imanente, as suas potencialidades malbaratadas e especular a respeito de um outro destino para o capitalismo tardio.

Inicialmente, procurei reconstruir alguns aspectos da sociologia da religião de Weber. De maneira geral, o objetivo foi contrastar as análises weberianas do processo de abstração que remontaria às origens das ações mágico-religiosas e agudizou-se com as doutrinas religiosas monoteístas com as realizadas por Adorno e Horkheimer. Conquanto as suas categorias sejam facilmente reconhecíveis e todo o trajeto do esclarecimento possa ser pensado à luz da sociologia weberiana, a apropriação dos frankfurtianos é bastante particular.

Por fim, julguei conveniente diferenciar a discussão estabelecida em DE com a realizada por Horkheimer em Eclipse da Razão. Ainda que o sejam trabalhos muito próximos, há certa especificidade no tratamento da sociologia de Weber no livro escrito exclusivamente por Horkheimer. Para tanto, redigi um apêndice ao segundo capítulo de minha tese no qual tentei trazer à tona essas diferenças.

No terceiro capítulo, concentrei-me na análise da presença de Weber nos ensaios e trabalhos tardios de Adorno. Novamente, uma análise comparativa com as questões apresentadas nos dois primeiros capítulos será fundamental. Em termos gerais, as reflexões metodológicas de Weber voltam ao centro das discussões. Porém, não apenas os conceitos weberianos serão distintos dos discutidos na incursão de Horkheimer da década de 1930 como a própria avaliação adorniana será sensivelmente diferente.

Por fim, o último capítulo desta tese versará a respeito da leitura de Marcuse a respeito da sociologia weberiana. Para tanto, o principal texto analisado foi o "Industrialização e capitalismo na obra de Max Weber”. Além desse artigo, também foi preciso interpretar algumas questões apresentadas principalmente nas seguintes obras de Marcuse: A Ideologia da Sociedade Unidimensional e Eros e Civilização. De modo geral, as críticas e análises de Marcuse recaem 
sobre (a) uma forma específica de contágio entre o conceito weberiano de razão ocidental e os pressupostos materiais e culturais das sociedades modernas, (b) a complexa relação entre as formas racionalizadas de domínio e a ascensão de lideranças carismáticas nas modernas democracias de massa e, finalmente, (c) uma reavaliação realizada por Marcuse do novo papel desempenhado pelo ascetismo intramundano nas sociedades industriais avançadas. Além desses pontos, (d) julguei ser necessário redigir um item a respeito das considerações de Marcuse sobre a ciência, a técnica e o trabalho no capitalismo avançado. 


\section{Cap. 1 - Contenda sobre meios e fins. Horkheimer e Weber na década de 1930.}

\section{A teoria crítica versus uma ciência empírica.}

Em “Teoria tradicional e teoria crítica”, a sociologia de Weber encontra-se classificada entre as correntes do pensamento que compreendem a teoria em seu sentido tradicional. De acordo com Horkheimer, o conceito de possibilidade objetiva, desenvolvido a partir da polêmica com Eduard Meyer e baseado em teorias como as do fisiólogo Von Kries, e dos juristas e economistas Merkel, Liefmann e Radbruch, transportaria para a interpretação histórica e sociológica o modelo científico atuante nas ciências da natureza. Abstraindo ou ignorando qualquer reflexão a respeito de seu entrelaçamento ao processo vital da sociedade, a ciência assim concebida acomoda-se à parcialidade e ao acanhamento do papel que lhe é relegada no atual quadro da divisão do trabalho. Por meio de deduções baseadas em operações matematizantes, acredita estar de posse de um saber que conseguiria amplo acesso à ordem do mundo. No entanto, contenta-se com o conjunto desordenado e irracional de faticidades que se avoluma ante a observação imediata.

Ainda que o pensamento tradicional seja inseparável dos reais progressos técnicos da era capitalista e seu modo de funcionamento se imagine eterno ${ }^{6}$, ele já não mais atende à função real e nem ao que significa a ciência atualmente para a existência humana, pois, para tanto, ela deve se impregnar do interesse por um estado racional ${ }^{7}$. A respeito de Weber, Horkheimer afirma:

Segundo esse autor, do mesmo modo que para o especialista em direito penal, a

6 A esse respeito, em “Observações sobre ciência e crise”, Horkheimer discute a transformações históricas sofridas pela ciência, sobretudo nas décadas que antecederam a eclosão da primeira guerra mundial. Já convém ressaltar que a avaliação de Horkheimer do papel da ciência é bastante complexo. Não se trata meramente de condenar a priori a ciência moderna, mas de compreendê-la tendo em vista sua relação com a totalidade da vida social. Nesse sentido, menos do que uma censura abstrata e peremptória, Horkheimer elabora uma argumentação a fim de interpretar o contexto sócio-histórico no qual ela está inserida. $\mathrm{O}$ anuviamento de suas potencialidades é resultado da forma pela qual as relações sociais se efetivam nesse momento histórico concreto - algo com o que a ciência se relaciona dialeticamente. Segundo Horkheimer: "Na medida em que o interesse por uma sociedade melhor, que ainda predominava no Iluminismo, foi substituído pelo empenho em consolidar a eternidade do presente, um elemento obstrutivo e desorganizador se apoderou da ciência. Se os resultados científicos tiveram aplicação útil na indústria, ao menos parcialmente, por outro lado ela fracassava exatamente diante do problema do processo social global, que antes da guerra já dominava a realidade através das crises cada vez mais acentuadas e das lutas sociais daí resultantes. (...). A raiz dessas falhas, porém, não reside absolutamente na ciência em si, mas nas condições sociais que impedem o seu desenvolvimento e que acabaram conflitando com os elementos racionais imanentes à ciência." Idem. "Observações sobre ciência e crise”; p. 9.

7 Idem. "Teoria tradicional e teoria crítica”; p. 131-132. 
explicação para o historiador não consiste na enumeração mais completa possível de todas as circunstâncias ai presentes, mas em destacar a conexão entre certos componentes do acontecimento, para a continuação do processo histórico, e, por outro lado, os processos individuais determinantes. Esta conexão, por exemplo, o julgamento de que uma guerra foi desencadeada pela ação política de um estadista decidido, pressupõe logicamente que, no caso de esta política não ter sido levada a cabo, não se daria o efeito explicado por ela, mas outro. A afirmação de uma determinada causa histórica implica sempre que, no caso de sua não-realização, devido a regras de experiência conhecidas, e sob as circunstâncias vigentes, ocorreria um outro determinado efeito. As regras da experiências, neste caso, não são outra coisa que formulações do nosso saber a respeito dos nexos econômicos, sociais e psicológicos. Com sua ajuda construímos o percurso provável, omitindo ou incluindo a ocorrência que deve servir para explicá-lo. Opera-se com preposições condicionais, aplicadas a uma situação dada. Pressupondo-se as circunstâncias a, b, c, e, d, deve-se esperar a ocorrência q; desaparecendo p, espera-se a ocorrência r, advindo g, então espera-se a ocorrência s, e assim por diante. Esse calcular pertence ao arcabouço lógico da história, assim como ao da ciência natural. É o modo de existência da teoria em sentido tradicional. $^{8}$

Antes de prosseguir, entretanto, convém trazer ao lume alguns elementos metodológicos da sociologia de Weber. Em “Estudos críticos sobre a lógica das ciências da cultura”, a discussão se estabelece a respeito da pertinácia da imputação causal no âmbito das disciplinas que se ocupam da vida social. Embora o trabalho seja em alguma medida distinto do presente nas ciências da natureza, a história - e os seus saberes vizinhos - para ser pensada como algo além da mera crônica de personalidades e de eventos memoráveis requer que os acontecimentos sejam convertidos em objeto de uma ciência empírica.

Como passo primeiro e fundamental, deve-se distinguir clara e sistematicamente os problemas relacionados à suposta relação causal entre determinado fato histórico e a ação de homens concretos das perguntas ou das indagações a respeito do sentido ou do significado em termos de uma responsabilidade ética. De modo direto, a tarefa consiste em enquadrar as ações humanas numa reflexão que contraste os meios historicamente disponíveis e adequados com os fins e os objetivos visados pelos agentes. Não para balizar qualquer valorização das personalidades e dos fenômenos culturais, mas sim para compreender a ação dos atores no contexto sócio-histórico no qual eles se inserem. Segundo Weber:

Quando se afirma que uma determinada proposição matemática é “correta”, não há nenhum interesse em proposições como, por exemplo, o modo como se deu "psicologicamente" este conhecimento ou, por exemplo, se a "fantasia matemática", na sua potência máxima, só foi possível como fenômeno concomitante a determinadas anormalidades do "cérebro matemático". Tampouco significa, evidentemente, perante o

8 Ibidem; p. 129. 
fórum da "consciência”, a consideração de que o próprio “motivo”, avaliado eticamente de acordo com os ensinamentos da ciência empírica, teria sido completamente condicionado causalmente, ou, no caso de um juízo de valor sobre o valor estético de uma obra mal feita, nada interessa ao conhecimento se sua produção poderia ser concebida como sendo determinada da mesma maneira que a Capela Sistina. A análise causal de modo algum nos proporciona um juízo de valor, e um juízo de valor não é, em absoluto, uma explicação causal. E é exatamente por essa razão que a avaliação de um processo - por exemplo, o da "beleza” de um fenômenos natural - se situa numa esfera diferente da de sua explicação causal e, consequentemente, também a referência à "responsabilidade” do agente histórico perante a sua consciência ou perante a qualquer tribunal divino ou humano, bem com toda e qualquer intromissão do problema filosófico da "liberdade" na metodologia da história, eliminaria por completo o seu caráter de ciência empírica, o que também seria o caso se alguém quisesse introduzir milagres em séries causais. ${ }^{9}$

Diante da emaranhada infinitude de elementos atuantes nos fenômenos sociais, a ferramenta primordial da ciência é a abstração ${ }^{10}$. Pela trama dos seus conceitos, o fenômeno bruto tornado objeto da ciência é despojado de algumas de suas características concretas a fim de que os cientistas possam manejá-los consoante suas pretensões teóricas.

O conhecimento possível será sempre parcial e sem aspirações totalizantes. De acordo com Weber, esta condicionalidade das asserções científicas é comum a todas as áreas do saber. Se não há condições de formular juízos absolutamente seguros no âmbito das ciências da cultura, a incapacidade não advém da especificidade de seu objeto, mas do fato de se lidar sempre com a complexidade de um processo concreto. Do mesmo modo que é impossível antecipar exatamente em quantos fragmentos uma rocha se partirá ao colidir com o solo ou prenunciar de maneira inconteste as intempéries meteorológicas, a conduta humana só é apreensível conceitualmente com um grau variável de incerteza. No entanto, diferentemente dos processos naturais, apenas o comportamento humano ofereceria condições de ser compreendido internamente. Precisamente por seu caráter significativo, as ações e as relações sociais descortinam-se ao conhecimento científico

9 Weber, Max. "Estudos críticos sobre a lógica das ciências da cultura"; p. 163.

10 De acordo com Turner e Factor, esse processo de abstração se compõem em dois procedimentos, quais sejam, o isolamento e a generalização. O tratamento conceitualmente adequado dos eventos históricos seria pautado, portanto, segundo Turner e Factor: “Utilizando os termos de Weber, deve-se 'isolá-los' e 'generalizá-los'. Isolar é considerar uma relação causal nos termos de certo conjunto particular de condições, isolando-as assim da 'infinidade de condições' remanescentes que devem ser deixadas de lado. Generalizar é descrever em termos gerais. Ambos tipos de abstrações são requeridos no julgamento de possibilidade objetiva.” Turner, Stephen e Factor, Regis. "Objective possibility and adequate causation in Weber's methodological writings"; p. 12. Ainda consoante Turner e Factor, quanto ao procedimento de isolamento dos demais fenômenos, não se deve entender que a existência dos fenômenos determinantes de algum acontecimento histórico não são a sua causa suficiente, isto é, a atuação dos mesmos elementos em uma outra situação histórica não significa que os resultados obtidos antes se reproduziriam automaticamente. 
em chances sensivelmente maiores de previsibilidade e de calculabilidade. Em "Knies e o problema da irracionalidade”:

\begin{abstract}
Conhecimento empírico no âmbito do "espírito" e naquele da "natureza” "exterior", dos processos "dentro de" nós e daqueles "fora de" nós, está sempre atado aos meios da "formação conceitual", e a essência de um "conceito" é logicamente a mesma nos dois âmbitos "substantivos". A peculiaridade lógica do conhecimento "histórico", em oposição àquela, em sentido lógico, "científico-natural”, não tem nada a ver com a distinção entre o "psíquico" e o "físico", entre a "personalidade" e a "ação" por um lado, e o "objeto da natureza" morto e o "processo natural mecânico" por outro. E menos ainda devem ser identificadas a "evidência" da "empatia" a "vivências" internas "conscientes" factuais ou potenciais - uma qualidade meramente fenomenológica da "interpretação" - com uma "certeza” especificamente empírica dos processos "interpretáveis”. - Uma "realidade” física ou psíquica, ou uma abrangendo ambas, é formada por nós como "indivíduo histórico" porque e na medida em que pode "significar" algo para nós; - comportamento ("ação") humano interpretável "com sentido" é apreendido de modo específico por nosso interesse causal na explicação "histórica” de tal "indivíduo" porque é determinável através de "valorações" e "significados". ${ }^{11}$
\end{abstract}

Retrospectivamente, as ciências da cultura acompanhariam o périplo traçado pelos agentes.

O homem de ação pondera, conforme seu conhecimento a respeito das condições externas que lhe cerca, quais caminhos conduzem ao futuro que lhe interessa atingir. Idealmente, introduz um nexo causal para se assegurar que, dentro dos diversos desdobramentos possíveis, ele possa desencadear resultados consoantes com suas expectativas. Por seu turno, o pesquisador parte de uma situação mais vantajosa. Já cônscio dos eventos subsequentes, ele deve escolher dentre os inúmeros fenômenos e acontecimentos históricos, os fatos decisivos e as relações causais determinantes para a efetivação de tal constelação. Por tais meandros, abre-se ao cientista o conjunto das possibilidades de atuação com o qual o agente se depara. Quanto maior for o grau de clareza e de discernimento acerca dos objetivos visados e dos meios apropriados para a execução de uma dada ação histórica isto é, quanto mais imune ela for às coerções físicas e psíquicas de toda ordem e aos afetos que perturbam e condicionam o juízo a respeito da equação bem equilibrada entre meios e fins -, mais compreensível ela se torna à interpretação científica.

No âmbito das ações plenamente racionais haveria perfeita transparência para o analista. Por meio do recurso a regras universais da experiência, as ciências da cultura tornam-se capazes de não apenas examinar o passado histórico e mergulhar na particularidade de um acontecimento

11 Weber, Max. “Knies e o problema da irracionalidade.”; p. 34. 
específico, mas de formular máximas e apreender a legalidade própria de certos eventos e

fenômenos sociais. A dedução dos eventos subsequentes é pensada em uma linha de continuidade na qual a racionalidade da ação desempenha um papel essencial. As possibilidades de efetivação do transcurso de uma ação social são crescentes na medida em que os agentes se comportam de tal maneira. Embora não unívoco ou definitivo, delineia-se assim um método para permitir desvelar as cadeias causais pelas quais os acontecimentos históricos são articulados. Concomitantemente, a pesquisa histórica cria as condições necessárias para mensuração e comparação de diferentes perspectivas de análise e para averiguação de suas conclusões. Segundo Weber:

\begin{abstract}
Mas, consideremos agora estes "juízos de possibilidade” - isto é, as afirmações sobre o que aconteceria no caso de haver a eliminação ou a modificação de determinadas condições - mais precisamente perguntamos, num primeiro momento, de que maneira poderemos chegar, de modo propriamente dito, a eles? Não pode haver dúvida nenhuma de que, em todos estes casos, se se procede mediante isolamento e generalização; isto significa que decompomos o “dado" em seus "elementos” até que cada um deles possa ser incluído numa "regra de experiência”, e, portanto, possa ser constatado qual resultado era o "esperado" de cada um, considerando "isoladamente” segundo uma "regra da experiência”, e dada a presença de outras condições. Portanto, o "juízo de possibilidade”, no sentido em que nós o usamos, sempre significa, pois, a referência a regras de experiência. A categoria de "possibilidade", consequentemente não se usa aqui na sua forma negativa, ou seja, no sentido de que expressa o nosso "não-saber” ou o nosso "saber incompleto" em oposição ao juízo assertórico ou apodítico; pelo contrário, ela implica a referência a um saber positivo sobre as "regras do acontecer" e, portanto, como se costuma dizer, com referência ao nosso conhecimento "nomológico". ${ }^{2}$
\end{abstract}

Do lado oposto, as ações e os eventos históricos seriam praticamente incompreensíveis na exata medida em que se afastem do tipo ideal de uma ação racional. De acordo com Weber, não apenas o objeto das ciências da cultura praticamente se desintegra ante tais circunstâncias. As noções de racionalidade da ação e de liberdade subjetiva coadunam-se internamente em sua argumentação ${ }^{13}$. As afirmações que pretendem equiparar a noção de liberdade a qualquer tipo de irracionalidade ou de incalculabilidade da conduta humana são vigorosamente combatidas pela sociologia weberiana. Marcados essencialmente pela ausência de determinações objetivas e eternamente sujeitos às contrariedades da contingência histórica, os indivíduos só são capazes - e

12 Idem. "Estudos críticos sobre a lógica das ciências da cultura”; p. 200.

13 Segundo Gabriel Cohn: “O estabelecimento de relações causais entre cursos de ação está, portanto, intimamente ligado à questão da racionalidade da própria ação. Mas, como a circunstância das ações terem causas não deriva de quaisquer atributos objetivos intrínsecos ao mundo mas da própria capacidade dos homens de criarem a racionalidade como valor e orientarem suas ações em consonância com isso, fica de pé a idéia de que a causalidade não é a marca da servidão dos agentes às exigências 'objetivas', mas de sua própria liberdade, ainda que 'subjetiva' da sua autonomia, no sentido que Weber concede ao termo.” Cohn Gabriel. Crítica e resignação; págs. 123-124. 
apenas precariamente - de sobrepujar o cego acaso mundano quando incorporam um universo de valores em suas ações e em suas relações sociais. Por mais quebradiços que sejam, esses vínculos passam a responder, necessariamente, também às demandas de coerência lógica interna e de ausência de contradição. Somente assim os agentes conseguem conformar o seu destino às exigências de racionalidade oriundas da aspiração a um objetivo ou a um fim específico. Preservados da demasiada instabilidade de elos puramente afetivos ou tradicionais, ao dotar de significado as práticas sociais com as quais os agentes se defrontam, estabelece-se a possibilidade de pensar os indivíduos como sujeitos autônomos.

A personalidade dos sujeitos, portanto, não deve ser vista como um enigma insolúvel. A autonomia dos indivíduos resguarda sua essência nessa constância da relação interna com determinados valores e significados últimos da vida. Se é possível falar em liberdade e autonomia humanas, elas não se equiparam à brutal imperscrutabilidade de sentimentos e de afetos. As fantasias em torno da necessidade do devir natural ou das sombras de uma concepção “romântico-naturalista” da existência são completamente distantes dos verdadeiros motivos que tornam a vida humana em algo não-heteronômico.

A ação realmente livre não zomba da imputação causal. O livre-arbítrio não advém da imprevisibilidade da atuação dos elementos mais misteriosos refugiados no obscuro e indiferenciado subsolo da vida vegetativa ${ }^{14}$, mas mostra-se presente com as ponderações próprias dos indivíduos não condicionadas por pressões externas ou internas aos agentes. A insensatez da atuação desses humores apenas dá vazão a atitudes que entram em contradição com as suas reais intenções. Esta vivência corriqueira de uma ação que se movimenta nos bastidores e predispõem os homens a se comportarem de forma distinta do querer conscientemente formulado não tem nada de autônoma. Em vez de garantir a sacralidade do modo especificamente humano de conduta, ela os mantém atrelados às reações próprias dos animais ${ }^{15}$. Em "Knies e o problema da irracionalidade”:

14 Weber, Max. "Knies e o problema da irracionalidade”; p. 31.

15 Ibidem; p. 30. 
Na análise do comportamento humano, nossa demanda causal pode encontrar uma satisfação qualitativamente diferente, a qual simultaneamente acarreta uma coloração qualitativamente diversa do conceito de irracionalidade. Para sua interpretação podemos, pelo menos em princípio, colocar-nos a meta de não apenas torná-lo “concebivelmente possível” no sentido da concordância com nosso saber nomológico, mas de “compreendê-lo”, isto é, encontrar um "motivo" concreto "revivenciável internamente”, ou um complexo destes, ao qual o imputamos com um grau diverso de univocidade, dependendo da fonte material disponível. Em outras palavras: por princípio, a ação individual, por sua interpretatividade significativa - até onde esta alcança -, é especificamente menos "irracional” do que o processo individual da natureza. ${ }^{16}$

É interessante começar a analisar as posições de Horkheimer. Também para o frankfurtiano o conhecimento nas ciências sociais e humanas traria, a princípio, resultados mais promissores e confiáveis do que o proveniente da investigação de processos naturais. Se não o são, se a sociologia tem de se a ver reiteradamente com os dessabores das contradições entre suas asserções teóricas e o curso das sociedades capitalistas, essa deficiência não está obrigatoriamente atrelada à falta de argúcia e de capacidade intelectual de seus representantes. Na verdade, trata-se da expressão de uma cisão que caracteriza as formas de sociabilidade existentes até o presente.

O antagonismo entre os indivíduos e a sociedade, cuja forma de expressão se modifica historicamente, atravanca as legítimas aspirações científicas pelos eventos futuros. Para que fosse possível predições seguras ${ }^{17}$, o próprio ordenamento social deveria ficar à merce de escolhas que não se confundem com a prosaica equação entre meios e fins. A razão e a vida social se tornarão transparentes na medida em que os homens não mais ajam como membros de um organismo irracional ${ }^{18}$, isto é, tão somente quando se ultrapassar os limites impostos pelo modo de produção

16 Ibidem; p. 28.

17 Embora a edição disponível no Brasil pela editora Perspectiva do ensaio "Zum Problem der Voraussage in den Sozialwissenschaft" (1933) utilize o termo "previsão" no título do artigo, como bem chamou a atenção Stefan Fornos Klein, a tradução mais adequada seria "predição". Nesse artigo, Horkheimer utiliza-se de dois termos, quais sejam, o "Voraussage" (cujo sufixo "sage" advém do verbo "sagen", i.e., dizer) e "Voraussicht" (com o sufixo derivado da palavra visão - Sicht - em alemão). Fornos Klein, Stefan. A universidade e a sociologia segundo Max Horkheimer. p. 110. A observação crítica não é apenas um preciosismo acadêmico, mas há uma questão substantiva de fundo. A observação crítica não é apenas um preciosismo acadêmico, mas há uma questão substantiva de fundo. Enquanto a previsão científica designaria uma relação com leis abstratas, por meio das quais seria possível sustentar julgamentos de que, dada determinadas condições, deveriam muito provavelmente desencadear alguns acontecimentos na realidade. Tal postura científica seria bastante comum sobretudo nas ciências naturais. As predições, por outro lado, lidariam com fatos concretos. Horkheimer volta suas atenções precisamente a esse tipo de conhecimento das ciências sociais. Segundo Horkheimer: "No entanto, não consigo concluir daí que, por esta razão, predições concretas para o futuro, como, por exemplo, as que Marx tentou, devam ser quase impossíveis, mas, em todo caso, de pouco valor científico. Pois, as leis não são a meta da atividade científica, são meros meios auxiliares; o importante é passar das fórmulas legais abstratas para os julgamentos existenciais concretos, e estes, em todo o domínio das ciências naturais, nunca incluem apenas passado ou presente, mas sempre também o futuro.” Horkheimer, Max. “Do problema da previsão nas ciências sociais”; p. 91.

18 Idem. "Teoria tradicional e teoria crítica”; p. 139. 
capitalista, e a vida social ser transformada em resultado da espontaneidade consciente de indivíduos livres ${ }^{19}$. Enquanto se continuar a reboque de uma economia que multiplica crises e exacerba contrastes e diferenças sociais de forma imanente, a consonância entre a teoria sociológica e os acontecimentos sociais será sempre precária e inautêntica. Em "Do problema da previsão nas ciências sociais”:

Para a sociologia, não obstante, ela tem sua importância. Com efeito, é inexato que a predição somente seja possível quando a ocorrência das condições necessárias depende propriamente daquele que prediz, mas a predição se torna mais provável quanto mais as circunstâncias condicionais dependerem da vontade dos homens, ou seja, quanto mais o resultado predito não for produto da natureza cega, mas efeito de decisões racionais. (...). Antes, estas predições são tão imprecisas, porque os fatos sociais ainda não são de modo nenhum os produtos da liberdade humana, mas resultados naturais da atuação cega de forças antagônicas. O modo como a nossa sociedade mantém e renova sua vida se assemelha mais à evolução de um mecanismo natural do que a um modo cônscio de agir. Por isso, o sociólogo opõe-se a ela como a um acontecimento que lhe é essencialmente estranho. É atingido por ele, de uma certa forma até participa dele, mas sua tarefa consiste em aceitá-lo como observador, registrá-lo, descrevê-lo e, se possível, explicá-lo. Certamente, os fatos sociais são produzidos por intermédio de pessoas mas, apesar disso, elas os experimentam como eventos independentes delas e fatais. ${ }^{20}$

Precária, pois as sociedades modernas não são organizadas a partir de critérios substancialmente racionais. A administração da economia e da política, a formação subjetiva dos indivíduos, a constituição e o funcionamento das esferas culturais, isto é, todos os momentos que compõem a totalidade da vida coletiva sofrem, igualmente, pelas incoerências daquilo que foi constituído pela modernidade capitalista como formalmente racional.

Ao descrever o enredo dessa rústica razão, é certo que as vertentes tradicionais da sociologia conseguem captar - e muitas vezes com grande perspicácia - determinados elementos essenciais dessas sociedades. Porém, elas são cotidianamente surpreendidas por fenômenos que não se comportam de acordo com os parâmetros imaginados em sua trama conceitual. Ademais, ainda que a própria gnosiologia dominante se veja impelida a tematizar sobre a recorrente disjunção entre suas

19 Também para Horkheimer a liberdade humana não se confunde com a irracionalidade de um arbítrio indeterminado. No entanto, por outro lado e diferentemente de Weber, ela tampouco pode ser pensada apenas em termos de uma racionalidade formal. A esse respeito, segundo Horkheimer: "Pois a verdadeira liberdade humana não pode equiparar-se nem com a incondicionalidade nem com a mera arbitrariedade, porém é idêntica, por decisão racional, ao domínio da natureza dentro e fora de nós. Conseguir que este estado de coisas se torne característico da sociedade é tarefa não apenas do sociólogo, mas também dos esforços progressistas da humanidade em geral. E, assim, o empenho do sociólogo em atingir a predição exata transforma-se no esforço político em prol da realização de uma sociedade racional.” Idem. “Do problema da previsão nas ciências sociais”; p. 94.

20 Ibidem; p. 93. 
considerações teóricas e a empiria, a ciência ordenadora ilude-se com uma insossa superfície ao pressupor como supra-histórico o coetâneo desarranjo entre sujeito, objeto e teoria. Por meio de suas categorias coisificadas se busca apenas expressar cada vez melhor o mundo miserável que se apresenta aos olhos dos cientistas ${ }^{21}$.

O desemprego e a malversação de forças produtivas, as crises econômicas, as guerras e a militarização dos governos e o atual estado das massas são tidos equivocadamente como consequências de uma limitação de natureza técnica, e não como desfecho das inadequadas condições da estrutura social de produção ${ }^{22}$. No período histórico no qual os órgãos humanos se converteram em apêndices rasteiros de ferramentas e de maquinarias, a expansão desbragada do poder humano sobre a vida em sociedade confundiu-se no celerado trote de suas pernas. A humanidade passou a contemplar um espetáculo mesquinho. A possibilidade de determinar racionalmente o curso dos acontecimentos deu lugar a uma prática intelectual que se jacta em registrar pormenorizadamente aquilo que lhe rodeia, mas se cala diante da tarefa de transformar o mundo. Segundo Horkheimer:

\begin{abstract}
A totalidade do mundo perceptível, tal como existe para o membro da sociedade burguesa e tal como é interpretável em sua reciprocidade com ela, dentro da concepção tradicional do mundo, é para seu sujeito uma sinopse de faticidades; esse mundo existe e deve ser aceito. O pensamento organizador concernente a cada indivíduo pertence às reações sociais que tendem a se ajustar às necessidades de modo mais adequado possível.
\end{abstract}

21 Idem; p. 135.

22 Nesse sentido, diferentemente do que Honneth afirma em Kritik der Macht, o papel da teoria crítica não me parece se restringir à função de uma consciência mais ampla dos processos sociais, cuja principal - e talvez única tarefa fosse relembrar os homens do seu real protagonismo na construção do mundo social. Segundo Honneth: "Horkheimer sustenta-se implicitamente sobre o pressuposto de uma filosofia da história, quando ele expõe como as conquistas do trabalho social tornam o processo emancipatório possível, por meio do qual o mundo humano livra-se do poder esmagador da natureza e que conduziu a um estado de uma natureza dominada e levou a civilização cada vez mais enriquecida. Mas para tal situação a teoria tradicional - e esse é o aspecto que interessa a Horkheimer - permanece cega; (...) a teoria tradicional concebe-se, com grande equívoco, como 'pura' teoria. Portanto, Horkheimer pode considerá-la, em uma maneira que lembra o jovem Marx, que não apenas o seu objeto específico, mas também o seu próprio modo pelo qual ela entra em contato com a realidade são preformados pelo correspondente estado das forças produtivas, isto é, pelo acumulo de controle efetivo sobre os processos naturais e sociais.” Honneth, Axel. Kritik der Macht; p. 13-14. A meu ver, essa é também uma das incumbências da teoria crítica, sem se reduzir, no entanto, a isso. Na verdade, tal como a ciência tradicional, a teoria crítica é uma expressão das contradições imanentes de um processo social que se concebe como um fenômeno natural. O pensamento tradicional segue em linha de continuidade com essa concepção equivocada da vida social. A teoria crítica, por outro lado, relevaria não apenas o caráter histórico, ou seja, como resultado da interação entre o trabalho humano e a natureza, mas também os aspectos contraditórios de todo o processo. Não se trata de pensar a teoria crítica como uma visão de conjunto da forma pela qual os homens se relacionam com os outros homens e com a natureza, mas portadora de reivindicações por uma alteração substancialmente racional - isto é, qualitativamente distinta - dessas interações. 
Porém, entre indivíduo e sociedade existe uma diferença essencial. O mesmo mundo que, para o indivíduo, é algo em si existente e tem que captar e tomar em consideração é, por outro lado, na figura que existe e se mantém, produto da práxis social geral. O que percebemos em nosso meio ambiente, as cidades, povoados, campos e bosques trazem em si a marca do trabalho. Os homens não são apenas um resultado da história em sua indumentária e apresentação, em sua figura e seu modo de sentir, mas também a maneira como vêem e ouvem é inseparável do processo de vida social tal como ele se desenvolveu através dos séculos. Os fatos que os sentidos nos fornecem são pré-formados de modo duplo: pelo caráter histórico do objeto percebido e pelo caráter histórico do órgão receptivo. Nem um nem outro são meramente naturais, mas enformados pela atividade humana, sendo que o indivíduo se autopercebe, no momento da percepção, como perceptivo e passivo. ${ }^{23}$

Inautêntica, pois o pressuposto da convergência eventual entre a teoria e a empiria é a ilegitimidade da sociedade em assumir o papel ativo de sujeito. Embora recoberta de vacilos e inúmeros pontos cegos, tal harmonia não é um simples acaso metafísico, mas se erige em bases sociais falsas. Seus momentos mais cintilantes, aqueles nos quais as indagações científicas entram em ressonância quase perfeita com o senso comum, não se livram da opacidade e do caráter turvo que acompanham toda e qualquer atividade no interior do ordenamento social.

Um consórcio inconsciente de práticas sociais e de atividades econômicas fomenta a síntese da experiência comum a todos os indivíduos. Sem basear sua onipresença em nenhum tipo de coordenação prévia, a racionalidade resultante do trabalho social é reencontrada nos gabinetes e nos laboratórios universitários, condicionando internamente tanto o objeto da ciência quanto o sujeito cognoscente. A aparência de universalidade é reforçada pela percepção subjetiva mais corriqueira. Os homens são cercados de mercadorias por todos os lados e sua capacidade de imaginação estiola-se diante de uma realidade formada por indústrias, conglomerados habitacionais, agências administrativas e departamentos de entretenimento.

Ainda assim, essa correspondência da percepção cotidiana não afasta plenamente o caráter cindido do todo. A antiga ilusão liberal de que os indivíduos isolados, ao buscarem a realização de seus interesses egoístas, manteriam a vida social em parâmetros razoáveis de civilidade já não convence a mais ninguém. Se tal desencanto não fosse suficiente, o ocaso do período liberal adiciona ao conjunto um grau ainda maior de irracionalidade. A dinâmica que acumula assombrosamente riqueza material e poder político é responsável também pela esterilidade dos

23 Horkheimer, Max. “Teoria tradicional e teoria crítica”; p. 151. 
últimos tempos. Sob condições capitalistas, o trabalho continua a produzir não apenas mercadorias,

mas também a realidade que escraviza de forma crescente e a miséria e a violência que aterrorizam

toda a humanidade. Em “Teoria tradicional e teoria crítica”:

O modo burguês de economia não é orientado por nenhum planejamento nem é orientado conscientemente para um objetivo geral, apesar da perspicácia dos indivíduos concorrentes; a vida do todo resulta numa figura deformada, como que por acaso, mesmo assim sob enormes atritos. As dificuldades internas que acompanham os conceitos mais elevados da filosofia kantiana, principalmente o Eu da subjetividade transcendental, a apercepção pura ou original e a consciência em si testemunham a profundidade e sinceridade de seu pensamento. O duplo caráter destes conceitos kantianos, que mostram por um lado a máxima unidade e orientação, e, por outro lado, algo de obscuro, de inconsciente, de intransparente, define exatamente a forma contraditória da atividade humana nos últimos tempos. A ação conjunta dos homens na sociedade é o modo de existência de sua razão; assim utilizam suas forças e confirmam sua essência. Ao mesmo tempo este processo, com seus resultados, é estranho a eles próprios; parece-lhes, com todo o seu desperdício de força de trabalho e vida humana, com seus estados de guerra e toda miséria absoluta, uma força imutável da natureza, um destino sobre-humano. ${ }^{24}$

Ao mesmo tempo, essa aturdida e improba harmonia, interpretada de maneira idealista por

Kant, é tanto o que permite à ciência tradicional legitimar suas operações e seus resultados quanto a

marca de sua não-verdade. Se já não é necessário permanecer nos céus do idealismo para

compreender a conexão pela a qual os saberes tradicionais retiram sua validade possível, tampouco

se justifica eternizar os procedimentos científicos burgueses. Embora não se abandone sem mais tais

práticas tradicionais, é premente reconhecer e superar o seu enviesamento.

A questão não se circunscreve em restringir ou eliminar os inconvenientes de um método

científico particular, mas a particularidade da própria razão que o fundamenta ${ }^{25}$. O anseio pelo novo

24 Ibidem; págs. 135-136.

25 Em Kritik der Macht, Honneth afirma que o pensamento de Horkheimer seria dependente de uma filosofia da história, arbitrária e sem comprovação empírica. Segundo Honneth: "Por seu turno Horkheimer só é coerente quando atrela a teoria crítica aos mesmos modos de atividades da espécie humana, dos quais apesar de seu auto-entendimento a teoria tradicional também deve ser desdobrada. Ambos os tipos de teoria seriam então formas de expressão igualmente dependentes do processo civilizatório de dominação da natureza; no qual, no entanto, a teoria crítica seria admitida como um saber esclarecido mais realista sobre o potencial de desenvolvimento das forças produtivas. Horkheimer apresenta essa interpretação sobretudo onde ele fala de uma tendência inerente do processo de trabalho à 'preservação, melhoria e desenvolvimento da vida humana'; a teoria crítica é, então, ela mesma a consciência do direcionamento imanente desse desenvolvimento.” Honneth, Axel. Kritik der Macht; p. 17. No entanto, diferentemente do que Honneth leva a crer, a teoria crítica e a tradicional não são expressões de um processo monolítico e unidimensional de dominação da natureza, do qual a teoria crítica seria a consciência mais abrangente e correta. Na verdade, esse processo comporta em si mesmo inúmeras contradições que cristalizam posturas práticas e teóricas com diferentes sentidos e significados. Segundo Fornos Klein: "A diferença que haveria, em meu entendimento, no modo como a teoria crítica da sociedade apresenta o curso da história consiste em seu entendimento eminentemente teórico, e não filosófico. O que se quer dizer com isso? Que o viés da filosofia pressuporia um telos histórico, algo que não é admitido na teoria social de Horkheimer: ele afirma que apresenta ou procura apontar as tendências existentes no processo social concreto, sempre fundamentadas sobre fatos - ou seja, de maneira materialista - e enfatizando sua dialética. Na medida em que grande parte dos problemas foram postos pela filosofia, e constituídos em um contexto histórico-filosófico (geschichtsphilosophisch), o seu conteúdo 
dita as regras do comportamento crítico. O desenrolar histórico não lhe é alheio. Seus conceitos e suas categorias carregam consigo o protesto radical contra a efetividade social. O mecanismo econômico triunfante necessita ser examinado a partir de um juízo existencial abrangente.

Prenhe de enlevo e de ardil, o capitalismo moderno e seus fenômenos associados são adequadamente conceitualizáveis quando não se perde de vista a totalidade de sua formação. Para além das correias da especialização acadêmica, o pensamento crítico deve ser capaz de interpretar a articulação entre o processo socioeconômico e o restante do tecido social ${ }^{26}$. As chagas do período inumano se revelam como fruto do conjunto dessa constelação. Sem desrespeitar seus preceitos reguladores, as sociedades capitalistas conduzem a humanidade a uma necessidade cega e sem sentido. Cabe à teoria crítica e aos esforços de superação dessa paralisia não apenas desvelar o caos vigente por trás da aparente normalidade, mas principalmente participar ativamente da luta pela sua radical transformação. Segundo Horkheimer:

A consideração que isola as atividades particulares e os ramos de atividade juntamente com os seus conteúdos e objetos necessita, para ser verdadeira, da consciência concreta da sua limitação. É preciso passar para uma concepção que elimine a parcialidade que resulta necessariamente do fato de retirar os processos parciais da totalidade da práxis social. $^{27}$

Por si só, a ciência tradicional não oferece mais muito auxílio para essa missão. Para Horkheimer, até mesmo em seus elementos mais recônditos, ela demonstra sua adesão à autopreservação e à reprodução contínua do existente ${ }^{28}$. Se no passado ela foi capaz de cristalizar uma atitude socialmente avançada ao se ocupar com a crítica às sociedades e aos privilégios feudais e com a formulação de ideais iluministas, há muito o pensamento tradicional transformou-se em trincheira de defesa das amarras forjadas pela ordem jurídica, política e cultural. Para se ir além

continua sendo de interesse, mas passam a ser abordados sob uma outra visada, em um debate crítico, que leva a sua crítica também para o aspecto epistemológico.” Fornos Klein, Stefan. A universidade e a sociologia segundo Max Horkheimer; p. 140.

26 De acordo com Martin Jay, o conceito de totalidade assume um aspecto crítico e não mais afirmativo na teoria crítica de Horkheimer. Segundo Jay: "Pois, como Horkheimer desconfiava do meta-sujeito absoluto, seja idealista ou marxista, ele era também implicitamente crítico ao conceito expressivista de totalidade empregado por Lukács para superar as antinomias do pensamento burguês. A noção de um unificado criador genérico da história era, como ele afirmou, uma ficção idealista. (...). Em contraste, para Horkheimer o materialismo sempre reconhecia a existência de um objeto natural irredutível à objetivação de um sujeito criador e resistente a todas as tentativas de dominá-lo conceitualmente. Jay, Martin. Marxism and totality; p. 214.

27 Horkheimer, Max. “Teoria tradicional e teoria crítica”; p. 132.

28 Ibidem; p. 131. 
desse estado de coisas, faz-se necessário traduzir no interior da prática acadêmica as reivindicações e as demandas por uma sociedade emancipada ${ }^{29}$. Não basta simplesmente priorizar uma temática específica ou balizar as formas e os objetivos de atuação dos movimentos de contestação política. O intelectual crítico relaciona-se com os grupos progressistas de forma dinâmica. Por certas vezes, suas contribuições são desprezadas ou vistas com grande desconfiança.

Todavia, com agudeza e perspicácia, ele não deve se furtar em produzir um conhecimento sobre a sociedade que se choque com alguns interesses mais imediatos das camadas populares e da classe dos trabalhadores. Em uma época na qual se encontra propensão à resignação mesmo entre aqueles que sofrem com o destemperamento da exploração econômica ${ }^{30}$, a radicalidade de um pensamento intransigente é a única segurança que a verdade pode ambicionar. Ante tal configuração, os termos útil, produtivo e valioso não podem fazer parte de seu vocabulário. O conhecimento crítico se pauta por outras premissas. Ele se norteia pela construção de uma sociedade emancipada. Segundo Horkheimer:

O especialista "enquanto" cientista vê a realidade social e seus produtos como algo exterior e "enquanto" cidadão mostra o seu interesse por essa realidade através de escritos políticos, de filiação a organizações partidárias ou beneficentes e participação em eleições, sem unir ambas as coisas e algumas outras formas suas de comportamento, a não ser por meio da interpretação ideológica. Ao contrário, o pensamento crítico é motivo pela tentativa de superar realmente a tensão, de eliminar a oposição entre a consciência dos objetivos, espontaneidade e racionalidade, inerentes ao indivíduo, de um lado, e as relações do processo de trabalho, básicas para a sociedade, de outro. O pensamento crítico contém um conceito de homem que contraria a si enquanto não ocorrer esta identidade. Se é próprio do homem que seu agir seja determinado pela razão, a práxis social dada, que dá forma ao modo de ser (Dasein), é desumana, e essa desumanidade repercute sobre tudo o que ocorre na realidade. Sempre permanecerá algo exterior à atividade intelectual e material, a saber, a natureza como uma sinopse de fatos ainda não dominados, com os quais a sociedade se ocupa. Mas neste algo exterior incluem-se também as relações constituídas unicamente pelos próprios homens, isto é, seu relacionamento no trabalho e o desenrolar de sua própria história, como um prolongamento da natureza. Essa exterioridade não é contudo uma

29 Helmut Dubiel afirma a esse respeito de Horkheimer: “(...) a ciência 'crítica' vê a politização interna da ciência (pela crítica à ideologia), analisando-a e inserindo no trabalho teórico a consciência de sua própria politização.” Dubiel, Helmut. Wissenschaftsorganisation und politische Erfahrung; p. 72.

30 De acordo com Wolfgang Bonß as principais reflexões teóricas de Horkheimer, sobretudo durante a década de 1930, surgiriam na necessidade de compreender a crescente contradição entre o antigo potencial revolucionário do proletariado e a sua progressiva integração ao capitalismo. Segundo Bonß: “(...) o aparente declínio da consciência de classe, o crescente papel de atitudes conservadoras e reacionárias e a evidente influência regressiva de tradições culturais deveriam ser elucidadas.” Bonß, Wolfgang. "The program of interdisciplinary research and the beginnings of critical theory”; p. 112. Movimento que, de acordo com Ricardo Musse, reflete-se na própria compreensão da Escola de Frankfurt a respeito da natureza da relação entre teoria e prática. Segundo Musse: “Comportamento e conhecimento orientados para a emancipação, para a transformação da totalidade social, a teoria crítica não configura, entretanto, uma prerrogativa exclusiva de uma classe, de um partido ou mesmo de uma intelligentsia.” Musse, Ricardo. De socialismo científico a teoria crítica; p. 76 
categoria supra-histórica ou eternas - isso também não seria a natureza no sentido aqui assinalado -, mas sim o sinal de uma impotência lamentável, e aceitá-la seria anti-humano e anti-racional. $^{31}$

Novamente, está-se diante de algo absolutamente distinto das elaborações weberianas. Para Weber deve haver uma completa cisão entre o papel do cientista e o do homem de ação. Nada seria mais pernicioso do que a contaminação dessas duas esferas. Sob risco evidente de atropelar o único valor que deve ser observado nas universidades - o da probidade intelectual ${ }^{32}$-, o homem de ciência precisa se despojar de suas convicções políticas e morais bem antes de adentrar a antessala de seu gabinete. Quem é capaz de suportar o cotidiano estafante de uma especialidade científica, quem se submete às aflições de uma atividade penosa não pode aspirar encontrar na pretensa verdade sobre a natureza ou em algum ideal normativo o confortável refúgio de suas inquietações intelectuais. Apenas poucos inebriados conseguem se contentar com os seus sóbrios resultados e com o acaso que circunda seu cotidiano profissional. A eles, a ciência não oferece nada além da possibilidade de tornar os homens cônscios das condições e das implicações de suas escolhas e de seus atos. A decisão acerca de quais objetivos atingir extrapola irremediavelmente os seus direitos.

\section{Em “Ciência como vocação”:}

Mas a política também não tem lugar, no que concerne aos docentes. E, antes de tudo, quando eles tratam cientificamente de temas políticos. Mais do que nunca a política está, então deslocada. Com efeito, uma coisa é tomar uma posição prática, e outra coisa é analisar cientificamente as estruturas políticas e as doutrinas de partidos. Quando, numa reunião pública, se fala de democracia, não se faz segredo da posição pessoal adotada e a necessidade de tomar partido de maneira clara, se impõe, então, como um dever maldito. As palavras empregadas numa ocasião como essa não são mais instrumentos de análise científica, mas constituem apelo político destinado a solicitar que os outros tomem posição. Não são relhas de arado para revolver a planície imensa do pensamento contemplativo, porém gládios para acometer os adversários, ou numa palavra, meios de combate. Seria vil empregar as palavras de tal maneira em uma sala de aula.(...). O verdadeiro professor se impedirá de impor, do alto de sua cátedra, uma tomada de posição qualquer, seja abertamente, seja por sugestão - pois a maneira mais desleal é evidentemente a que consiste em "deixar os fatos falarem”. ${ }^{33}$

Pois não seria evidente e nem necessário que uma atividade sujeita às leis do progresso seja a morada de algo dotado de sentido ${ }^{34}$. Primeiramente, o trabalho do cientista deve se resignar diante

31 Horkheimer, Max. “Teoria tradicional e teoria crítica”; p. 140.

32 Weber, Max. "Ciência como vocação”; p. 51.

33 Ibidem; págs. 38-39.

34 A esse respeito, Pierucci afirma: "Eis aí uma razão suficiente para sentirmos vertigem: o conhecimento científico progride sem parar, Weber não tem a menor dúvida quanto a isso. Ele não só não tem um paradeiro, como não tem parada. Seu desenvolvimento é 'progresso' no sentido técnico da palavra, e isso quer dizer que a lógica interna da 
da absoluta efemeridade e precariedade de seus achados. A fim de que a ciência avance continuamente, há sempre à sua espreita a premência de superação até mesmo dos teoremas mais sofisticados. A incerteza e a insegurança também se multiplicam entre seus partidários. Embora sem diligência e sem desvelo não haja pesquisa científica bem sucedida, a inspiração - também essencial para a prática intelectual - prefere não raramente a despreocupada intuição do diletante à fatigosa labuta do especialista. Somada a essa alta propensão à frustração subjetiva, não se é possível elaborar qualquer critério objetivamente válido de hierarquização dos valores. Das convicções mais arrepiantes à sensibilidade moderna aos ideias mais sublimes surgidos com o iluminismo não há escolha racional possível. O preço a ser pago é o mesmo de outrora. São os antigos deuses e demônios que continuam a governar as escolhas. Mesmo despidos da sacralidade e sujeitos às profanações de uma época desencantada, suas seduções permanecem poderosas.

No mesmo sentido, para Weber é essencial reconhecer o mais fundamental ensinamento que a consideração empírica do mundo pode nos proporcionar. As ciências da cultura só lidam com visões de mundo na medida em que as considera objeto de suas preocupações. Não para formular uma mais autêntica e substancialmente racional, mas sim para compreender de forma neutra e desapaixonada a influência que elas desempenham nos motores internos de uma ação ou de uma relação social. Segundo Weber:

Os cientistas podem - e devem - mostrar que tal ou qual posição adotada deriva, logicamente e com toda certeza, quanto ao significado de qual ou tal visão última e básica do mundo. Uma tomada de posição pode derivar de uma visão única do mundo ou de várias, diferentes entre si. Dessa forma, o cientista pode esclarecer que determinada posição deriva de uma e não de outra concepção. Retomemos a metáfora que há pouco nos valemos. A ciência mostrará que, adotando tal posição, certa pessoa estará a serviço de tal Deus e ofendendo tal outro e que, se se desejar manter fiel a si mesma, chegará, certamente, a determinadas consequências íntimas, últimas e significativas. Eis o que a ciência pode proporcionar, ao menos em princípio. Essa mesma obra é o que procuram realizar a disciplina especial que se intitula filosofia e as metodologias próprias das outras disciplinas. Se estivermos, portanto, enquanto cientistas, à altura da tarefa que nos incumbe (o que, evidentemente, é preciso aqui pressupor) poderemos compelir uma pessoa a dar-se conta

esfera científica a arrasta de modo irreversível a acumular um estoque sempre maior e sempre mais atualizado de conhecimento sobre o mundo. (...). Seu percurso é revolucionário, ascendente e unidirecional, mas não se consuma, não tem repouso, provisório que é, sempre, limitado que é, sempre, especializado que é, sempre, e por isso parcial. Sempre. Nunca total, nunca totalizante nem definitivo. Nessa constante e progressiva auto-superação reside, para Weber, o 'problema de sentido' da ciência. Quem não entender isso, 'melhor fará se permanecer alheio ao trabalho científico.” Pierucci, Flavio. O desencantamento do mundo; págs. 157-158. 
do sentido último de seus próprio atos ou, quando menos, ajudá-la em tal sentido. ${ }^{35}$

Para Horkheimer, o pensamento não pode se perder nessa dualidade. A representação intelectual que separa integralmente o pensar e o ser, o entendimento e a sensibilidade, a teoria e a prática social cristaliza a própria condição atual das sociedades capitalistas. Ela é válida apenas quando se pretende permanecer dentro de uma ordem social que fora transformada em um mecanismo quase-natural. Ao se ousar ir além, o caráter contraditório do todo deixa de ser escamoteado e o dualismo que caracteriza a ciência tradicional mostra-se como algo possível de ser superado.

O trabalho social constitui a totalidade da sociedade. Contudo, ele não é desempenhado conforme um plano conscientemente elaborado. Em alguma medida, os homens não se esquecem do fato de que a sociedade fora construída a partir da sua atividade. Porém, a reação mais trivial é o estranhamento entre a ação humana e os seus resultados. O mundo se afigura em sua imediaticidade como produto do capital e não como consequência da vontade coletiva da associação de seres racionais. Trata-se dos movimentos prostrados de um autômato, cujo objetivo não se coaduna com anseios humanos, mas sim com a produção ampliada de mais-valia.

Diante de tais disparates, a teoria crítica necessita recuperar o potencial emancipatório inscrito no próprio pensamento. Sem se confundir com qualquer compreensão ideológica de seu lugar, como, por exemplo, a ideia de uma intelligentsia que acredita pairar acima das divisões de classe $^{36}$, o intelectual crítico explicita claramente seus interesses. Por meio da interpretação rigorosa do presente histórico, ele deve defender tenazmente a fantasia que conduz à uma sociedade sem exploração econômica e sem dominação política. Segundo Horkheimer:

35 Weber, Max. “Ciência como vocação”; p. 46.

36 Segundo Horkheimer: “A teoria crítica está em contradição com o conceito formalístico do espírito, no qual se baseia tal representação de intelligentsia. Segundo ela existe só uma verdade e os predicados positivos de lealdade e coerência interna, racionalidade, anseio de paz, liberdade e felicidade não podem ser atribuídos no mesmo sentido a qualquer outra teoria e práxis. Não existe teoria da sociedade nem mesmo a teoria do sociólogo generalizador, que não inclua interesses políticos, e por cuja verdade, ao invés de manter-se numa reflexão aparentemente neutra, não tenha que se decidir ao agir e pensar, ou seja, na própria atividade histórica concreta. É inconcebível que o intelectual pretenda previamente realizar, ele próprio, um trabalho intelectual difícil, para só depois poder decidir entre metas e caminhos revolucionários, liberais ou fascistas. Há décadas a situação não é mais propícia para isso. A vanguarda necessita da perspicácia para a luta política e não de lições acadêmicas sobre a sua pretensa posição social.” Horkheimer, Max. “Teoria tradicional e teoria crítica”; p. 149. 
O futuro da humanidade depende da existência do comportamento crítico que abriga em si elementos da teoria tradicional e dessa cultura que tende a desaparecer. Uma ciência que em sua autonomia imaginária se satisfaz em considerar a práxis - à qual serve e na qual está inserida - como o seu Além, e se contenta com a separa

ção entre o pensamento e a ação, já renunciou à humanidade. Determinar o conteúdo e a finalidade de suas próprias realizações, e não apenas nas partes isoladas mas em sua totalidade, é a característica marcante da atividade intelectual. Sua própria condição a leva à transformação histórica. Por detrás da proclamação de "espirito social” e “comunidade nacional” se aprofunda, dia a dia, a oposição entre indivíduo e sociedade. A autodeterminação da ciência se torna cada vez mais abstrata. O conformismo do pensamento, a insistência em que isso constitua uma atividade fixa, um reino à parte dentro da totalidade social, faz com que o pensamento abandone a sua própria essência. ${ }^{37}$

Evidentemente, a questão não se esgota numa querela em torno de meros problemas metodológicos. Ora, tampouco a teoria tradicional é um desdobramento imanente de um processo intracientífico - as relações entre as suas hipóteses e os fatos se realizam na indústria e não na cabeça dos cientistas $^{38}$. A teoria crítica advoga em favor de uma nova ideia de verdade. Ela baseia suas proposições na consciência da total indissociabilidade entre os conceitos de lógica e de racionalidade do processo histórico concreto. Embora não deva mais ser pensada em chave idealista, que pressupõe uma concepção liberal e abstrata de indivíduo ${ }^{39}$, a possível identidade entre os sujeitos e os objetos se efetivará no futuro, quando as bases da sociedade forem radicalmente transformadas. Sem cair nas tentações da produção de um saber que se imagina absoluto, romper o sombrio pacto do intelectual com o mundo inumano significa encarar a vida social como uma obra inconclusa. Não porque se espere candidamente que as suas arestas sejam aparadas, mas sim que a construção de uma sociedade emancipada requer esforços contínuos e persistentes visando a real melhoria das condições de vida de todos os indivíduos - que não deve ser confundida com o simples aumento dos padrões de consumo. Segundo Horkheimer:

O pensamento não inventa estórias a partir de sua própria fantasia, antes exprime a sua função interior. Em seu percurso histórico os homens chegam à gnose do seu fazer e com isso entendem a contradição encerrada em sua própria existência. A economia burguesa estruturou-se de tal forma que os indivíduos, ao perseguirem sua própria felicidade, mantenham a vida da sociedade. Contudo essa estrutura possui uma dinâmica em virtude da qual se acumula, numa proporção que lembra as antigas dinastias asiáticas, um poder fabuloso, de um lado, e, de outro, uma impotência material e intelectual. A

37 Ibidem; p. 162.

38 Ibidem; p. 130.

39 A esse respeito, segundo Martin Jay: “O indivíduo deveria ser entendido como mediado por uma totalidade não-idêntica, nunca como um ponto final em si mesmo. Ao enfatizar o momento negativo do processo dialético, os autores da teoria crítica fomentaram uma consciência crítica que parecia ausente tanto no marxismo humanista como no científico.” Jay, Martin. “The Frankfurt School's critique of marxist humanism.”; p. 27 
fecundidade original dessa organização do processo vital se transforma em esterilidade e inibição. Os homens renovam com seu próprio trabalho uma realidade que os escraviza em medida crescente e os ameaça com todo tipo de miséria. A consciência dessa oposição não provém da fantasia, mas da experiência. ${ }^{40}$

Isto posto, pode-se afirmar que onde Weber enxergava ser a condição necessária para o exercício da sociologia enquanto ciência empírica e, ao mesmo tempo, fundamentava a liberdade e a autonomia humana corresponde para Horkheimer às contorções peculiares de heteronomia de um sujeito ilegítimo. É interessante ressaltar que, no interior da própria sociologia weberiana, essa associação entre a racionalidade da ação e a liberdade humana pode ser lida a partir de um desenlace contraditório. O amplo processo histórico que culminou na formação das sociedades modernas, que atingiu o mais alto grau de racionalidade formal em suas instituições, libertando o pensamento científico e a produção cultural de amarras religiosas, permitindo à economia e à política se organizarem a partir de critérios internos de legalidade, paradoxalmente condenou-se ao destino mais imperscrutável.

Incapazes de responsabilizar por seus infortúnios qualquer poder misterioso, os indivíduos modernos parecem ter apenas uma e desastrosa saída - resignarem-se a suportar indefinidamente as agruras de uma vida penosa e sem sentido a espera de um novo profeta. Mas, como se invertessem uma ainda esperançosa profecia de Kafka, a de que o salvador chegará quando não for mais esperado, já se sabe de antemão que ele não virá. Em A ética protestante:

O puritano queria ser um profissional - nós devemos sê-lo. Pois a ascese, ao se transferir das celas dos mosteiros para a vida profissional, passou a dominar a moralidade intramundana e assim contribuiu [com a sua parte] para edificar esse poderoso cosmos da ordem econômica moderna ligado aos pressupostos técnicos e econômicos da produção pela máquina, que hoje determina com pressão avassaladora o estilo de vida de todos os indivíduos que nascem dentro dessa engrenagem - não só dos economicamente ativos - e talvez continue a determinar até que cesse de queimar a última porção de combustível fóssil. Na opinião de Baxter, o cuidado com os bens exteriores devia pesar sobre os ombros de seu santo apenas “qual leve manto que se pudesse despir a qualquer momento”. Quis o destino, porém, que o manto virasse uma rija crosta de aço \{na célebre tradução de Parsons: iron cage $=$ jaula de ferro . No que a ascese se pôs a transformar o mundo e a produzir no mundo os seus efeitos, os bens exteriores deste mundo ganharam poder crescente e por fim irresistível sobre os seres humanos como nunca antes na história. ${ }^{41}$

É justamente este o desafio que Horkheimer propõe elucidar - as sociedades modernas

40 Horkheimer, Max. “Teoria tradicional e teoria crítica”; p. 142.

41 Weber, Max. A ética protestante e o “espírito” do capitalismo; p. 165. 
terem se tornado uma fatalidade. Tal desenredo não deve continuar a ser aceito como natural e nem permanecer incompreensível. Conquanto ainda não se consiga predizer de maneira inequívoca o que se pode esperar do futuro, os indícios parecem ser fortes e desalentadores. Prometendo manter coeso o todo contraditório, a argamassa cultural realiza diuturnamente o seu trabalho. Para dinamitar e despedaçar esta marcha soturna e monótona, os aspectos culturais que fomentam um comportamento resignado não devem continuar com a palavra final.

A disputa no interior da cultura, esse feixe complexo de elementos que atuam para a manutenção ou para a dissolução dos regimes sociais, é uma aposta para disparar o rastilho. Fazer valer seus aspectos progressistas, orientar seus procedimentos por princípios substancialmente racionais e fomentar o debate crítico e intransigente a respeito de tudo que é tido como natural e inquestionável são as condições necessárias para se criar uma sociedade justa, culturalmente diferenciada e harmônica. Em "Sobre o conceito de verdade”:

Mas o domínio sobre a natureza não é exercido segundo um plano e intenção uniformes, mas constitui tão somente um meio para indivíduos, grupos e nações, que o empregam na luta entre si e que, ao desenvolvê-lo, ao mesmo tempo o limitam crescentemente e o conduzem a fins destrutivos. Por isso, os representantes deste espírito, com sua capacidade crítica e seu pensamento evoluído, ainda não se tornaram realmente seu senhor, mas são conduzidos pelas constelações alternantes da luta geral, as quais, embora produzidas pelos próprios homens, os defrontam como forças imprevisíveis do destino. Esta dependência aparentemente necessária, que se evidencia cada vez mais em forma de tensões e crises destrutivas, de miséria e ruína geral, se converte, para a maior parte da humanidade, numa incompreensível fatalidade. ${ }^{42}$

Assim, mais do que contrastar as proposições dos autores no que tange à natureza do conhecimento teórico e à prática profissional do intelectual, é fundamental discutir as origens dessas divergências. Para compreendê-las em sua integridade, acredito que se faça necessário relacioná-las às suas respectivas interpretações das sociedades modernas. Nesse sentido, convém perscrutar o modo pelo qual Weber e Horkheimer analisaram as bases e alguns desdobramentos da razão ocidental. Inicialmente, analisarei os diferentes diagnósticos a respeito da imbricação da razão com os interesses materiais e ideais de classes e grupos sociais. Se para Weber essa relação é examinada sob a perspectiva do florescimento do capitalismo moderno, Horkheimer investiga a questão em um

42 Horkheimer, Max. “Sobre o problema da verdade”; págs. 143-144. 
momento histórico posterior, qual seja, o de dissolução da fase liberal do capitalismo.

\section{A racionalidade ocidental ante novos interesses.}

Em “Introdução do autor”, Weber chama atenção para o ineditismo da forma de razão consolidada com a modernidade capitalista. O texto multiplica-se em indagações a respeito da peculiaridade cultural ocidental ou, diretamente, por quais motivos os produtos da moderna civilização europeia assumiram, com direito, um desenvolvimento de significado universal. Para além da violência e da imposição de crenças e de valores que marcou - e marca - a história dessa civilização, Weber questiona-se acerca do que distingue as produções socioculturais ocidentais de todas as demais $^{43}$ e, desse modo, possibilita que elas se estabeleçam como as construções formalmente mais racionais. Quais os fundamentos permitiram à administração do Estado e à condução dos partidos políticos, ao funcionamento da ciência, à ordenação da economia e à organização do trabalho e da indústria terem sido estruturados por critérios eminentemente racionais apenas no Ocidente? De maneira homóloga, por que somente nesse lugar e nesse momento histórico conheceu-se manifestações artísticas racionalizadas?

O exemplo histórico mais bem acabado da atuação desse tipo de racionalização se encontra, provavelmente, na própria definição weberiana de capitalismo moderno. Se os problemas das sociedades capitalistas assumem posição central na obra de Weber $^{44}$, o conceito de racionalismo ocidental pode ser interpretado como sua principal contribuição para a interpretação da peculiaridade histórica da modernidade ${ }^{45}$. Como já aparecera em A ética protestante, a

43 A respeito, Gabriel Cohn é cirúrgico: “A análise comparativa não opera, então, na busca do que seja comum a várias ou todas configurações históricas, mas, pelo contrário, procurará trazer à tona o que é peculiar a cada uma delas. Nas análises a que Weber se dedicaria posteriormente, essa visão comparativa ir-se-ia apurando cada vez mais, orientada pela busca daquilo que é específico ao mundo ocidental moderno - a presença de um capitalismo organizado em em moldes racionais e a racionalização da conduta em todas as esferas da existência - em termos da busca, em outras configurações históricas, de traços que não fossem congruentes com essa racionalização especificamente europeia da vida.” Cohn, Gabriel. “Introdução”; p. 15.

44 Cohn, Gabriel. Crítica e resignação. Max Weber e a teoria social; p. 118.

45 Segundo Schluchter: "De início, ele primeiramente interessou-se com a peculiaridade da moderna economia europeia, mas ampliando ele também lidou com a particularidade da moderna ciência europeia, arte, política e lei resumidamente, com toda estrutura da moderna cultura europeia. Podemos ir além: essas análises de toda uma configuração de uma manifestação cultural específica com seu possível significo histórico-mundial impeliu a comparação e mesmo a confrontação com alternativas. No curso de suas análises, o tema do capitalismo 
compreensão weberiana do capitalismo moderno o distingue substancialmente do impulso imediato para a aquisição, do capitalismo aventureiro, das formas de acumulação de capital que se efetivaram por vias abertamente violentas e não-racionalizadas.

O capitalismo politicamente orientado floresceu nas mais distintas épocas. Transitando da pura irracionalidade à apropriação bruta, o capitalismo assim constituído desenvolveu empresas econômicas como empreendimentos regulares, promoveu um vasto e importante comércio internacional e, inclusive, produziu instituições financeiras de porte. Entretanto, segundo Weber, ele mostrou-se incapaz de promover a moderação racional do impulso irracional de ganho ilimitado. É precisamente isso que individualiza o Ocidente. A moderna disposição em dominar pelo cálculo não encontrou paralelo em nenhum outro lugar. Apenas para o Ocidente, o balanço comercial das empresas assumiu importância vital.

Ainda que fosse preciso reiteradamente aquietar o seu entusiasmo, o mais relevante não seria tanto a sede insaciável e apressada pelo lucro, mas manter vigente as condições necessárias para realizá-lo de maneira contínua. A preocupação não se resume, portanto, em tornar o saldo comercial positivo. A duras penas, o capitalista aprende a lidar com seus negócios com uma curiosa parcimônia. Ao lado da cautela em não esgotar por um só lance as fontes e os recursos de sua riqueza material, internaliza-se um tipo de conduta que garante às suas volições pecuniárias uma sobrevida que se estenderia até que cessasse de queimar a última porção de combustível fóssil ${ }^{46}$. Segundo Weber:

Onde a aquisição capitalista é obtida racionalmente, a ação correspondente é ajustada por cálculo em termos de capital. Isso significa que a ação adaptada à utilização sistemática dos recursos ou dos serviços pessoais como meio de aquisição, de modo que, ao término de um período de negócios, o balanço da empresa, em termos de dinheiro, (ou, no caso de empresa permanente, o valor monetário estimado de seus bens) exceda o capital, isto é, o valor estima dos meios materiais de produção utilizados para a aquisição na troca. Não importa que isso envolva uma quantidade de bens in natura confiados a um caixeiro viajante, cuja renda pode ser outros bens in natura adquiridos em troca ou que envolva uma empresa manufatureira cujos ativos sejam prédios, máquinas, liquidez monetária, matéria-prima, produtos completa ou parcialmente acabados, tudo contabilizado contra os compromissos. O fato importante é que o cálculo do capital é sempre feito em dinheiro, quer pelos modernos métodos de contabilidade, quer por qualquer outro método, por mais

transformou-se no do racionalismo.” Schluchter, Wolfgang. The rise of western rationalism; p. 9.

46 Idem. A ética protestante e o “espírito” do capitalismo; p. 165. 
primitivo e grosseiro que seja. Tudo é feito em termos de balanços: um balanço inicial no começo da empresa; outro antes de qualquer decisão individual, como cálculo de sua provável lucratividade e um balanço final para apurar o lucro obtido. ${ }^{47}$

Tal disposição, entretanto, não surgiu por motivos econômicos e tampouco se iniciou com a modernidade capitalista. Embora seja o período no qual esse tipo de racionalização atingira o seu ápice, Weber remete sua formação a um processo histórico-religioso de longuíssima duração. Trata-se de certas consequências inesperadas de uma ética que, ainda vestida em trajes religiosos, dotou de significado a conduta de vida racional e moldou os homens consoante uma rígida disciplina cotidiana. O grande processo de desencantamento do mundo, onde se manteve fiel a sua coerência lógica interna diante das demandas desencadeadas pelo sentimento de inaudita solidão interior do indivíduo ${ }^{48}$, agiu a fim de eliminar a espontaneidade do gozo impulsivo em favor de uma metodização ética da vida.

Lutando contra uma muralha de hábitos, a internalização desse novo espírito não se deu pacificamente, mas foi cravejada de espinhos. Quando se saiu vitorioso, ele esvaziou de sentido o desfrute da vida em favor da valorização do trabalho ascético como um dever a ser cumprido independentemente de qualquer espécie de recompensa. Essa caçada sem descanso tornou racional uma conduta na qual o ser humano existe para o seu negócio e não o contrário. A ideia de que apenas o trabalho profissional mundano, único meio apropriado para a ab-reação dos afetos de angústia religiosa ${ }^{49}$, generalizou-se pelo Ocidente. Seu efeito social mais evidente foi ter transformado a atividade profissional em um fim em si mesmo e não como o meio de satisfação de necessidades, constituindo dessa maneira o comportamento ideal dos sujeitos econômicos modernos. De acordo com Weber:

O capitalismo hodierno, dominando de longa data a vida econômica, educa e cria para si mesmo, por via da seleção econômica, os sujeitos econômicos - empresários e operários - de que necessita. E entretanto é justamente esse fato que exibe de forma palpável os limites do conceito de "seleção" como meio de explicação de fenômenos históricos. Para que essas modalidades de conduta de vida e concepção de profissão adaptadas à peculiaridade do capitalismo pudessem ter sido "selecionadas", isto é, tenham podido sobrepujar outras modalidades, primeiro elas tiveram que emergir, evidentemente, e

47 Idem. "Introdução do autor”; págs. 9-10.

48 Idem. A ética protestante e o “espírito” do capitalismo; p. 95.

49 Ibidem; p. 102. 
não apenas em indivíduos singulares isolados, mas sim como um modo de ver portado por grupos de pessoas. Portanto, é essa emergência de um modo de ver que se trata propriamente de explicar. ${ }^{50}$

Uma das portas de entrada mais importantes dessa grande transformação foi aberta pela ascese religiosa. Se outrora o ascetismo fora confinado em monastérios ou apenas encontrado no fanatismo de virtuoses, ele passou a inundar quase a totalidade da existência humana dos puritanos, tornando-se uma realidade efetivamente intramundana. Essa nova postura tornou-se o componente ativo integrante de toda vida, de toda hora e de toda ação. A reforma protestante - e, em especial, o calvinismo com as doutrinas da predestinação e do particularismo da graça - deixou sem morada uma atitude ante a divindade que aparentava ser mais condizente com a emaranhada complexidade de desejos e de interesses embrenhados na ação humana. A tradicional acumulação progressiva de obras meritórias isoladas tornou-se pecaminosa demais para a autoinspeção sistemática dos puritanos.

Nada que se faça na Terra é suficientemente valoroso para alterar os desígnios perfeitos e transcendentes de deus. A dádiva de estar no seleto grupo dos eleitos deveria ser comprovada durante todos os momentos de suas existências. Uma postura benevolente aos prazeres macula-se, irremediavelmente, pela corrupção das criaturas, e tão somente a vida regrada em suas minúcias poderia significar a eternidade. O amor ao próximo cristão deixou de ser encarado pelo piedoso prisma da compaixão diante dos pecadores. Sob a impassível coação de uma teologia racional, qualquer condescendência fora intelectualmente concebida como a mais crassa heresia, como sinônimo da falta de amor e de respeito por deus. Segundo Weber:

Um dique foi erguido para impedir que a ascese continuasse a desbordar da vida cotidiana em meio ao mundo, e àquelas naturezas internalizadas e passionalmente sérias que até então haviam fornecido ao monacato os seus melhores representantes agora era ensinado que se devotassem a ideais ascéticos dentro da vida profissional mundana. Só que o calvinismo, na seqüência de seu desenvolvimento, acrescentou a isso um aporte positivo: a idéia da necessidade de uma comprovação da fé na vida profissional mundana. Fornecia assim [a amplas camadas de naturezas com pendor religioso] o estímulo positivo da ascese e, uma vez ancorada sua ética na doutrina da predestinação, a aristocracia espiritual dos monges situada além e acima do mundo cedia lugar à aristocracia espiritual dos santos no mundo desde toda a eternidade predestinados por Deus, aristocracia essa que com seu character indelebilis \{caráter indelével\} está separada do resto da humanidade, constituído de réprobos desde toda a eternidade, por um abismo em princípio intransponível e ainda

50 Ibidem; p. 48. 
mais inquietante em sua invisibilidade do que o do monge medieval apartado do mundo um abismo sulcado com áspera agudez em todos os sentimentos sociais. ${ }^{51}$

Essa longa jornada, fora também acompanhada e dependente de certas condições socioeconômicas não negligenciadas por Weber. Conquanto os motivos religiosos e as querelas teológicas sejam essenciais em sua conceitualização e, ademais, as éticas econômicas das religiões de salvação nunca terem sido interpretadas como simples reflexo ou como consequências diretas de interesses materiais, a tese contrária é igualmente parcial ${ }^{52}$. Há um intrincado entrelaçamento entre as ideias e as condutas de vida atadas aos dogmas e aos ritos religiosos e a maneira pela qual determinados grupos e estratos sociais conduziam a sua vida prática e suas atividades políticas e econômicas ${ }^{53}$.

Pois, se as visões de mundo orientam os interesses - ideais ou materiais - a certos atalhos ou descaminhos, seria também inegável o enredamento das considerações teóricas aparentemente mais sublimes e mais transcendentes às condições de vida na Terra. Desvelar a pré-história religiosa dos fenômenos que atuaram no surgimento das formas de sociabilidade modernas não é o bastante. Para se compreender o tipo de racionalização sedimentada no Ocidente é essencial traçar o complexo quadro de dependência mútua, recorrente e insofismável entre essas esferas. Sem cair na tentação de

51 Ibidem; págs. 110-111.

52 A esse respeito, segundo Schluchter: "Precisamente há sim, com direito, uma constituição histórica tanto materialista quanto idealista. Apenas se se persegue essa dialética em dupla perspectiva, pode-se atingir alguma 'verdade histórica', tão somente assim no campo, no processo de mediação entre objetivos, caminhos e interesses em diversas formas de sociedade. Com isso, deve-se manter o olhar orientado igualmente sobre os centros e as periferias, sobre as 'elites' e as 'massas': de um lado, sobre os portadores das ideias e dos interesses dominantes e os seus antagonistas e, por outro, sobre os seus possíveis 'seguidores'. Especialmente na sociologia da religião weberiana aparece essa constelação em especial destaque: de um lado, na oposição entre ortodoxia e heterodoxia e, por outro, na entre a 'união' de virtuosos e a religiosidade da massa.” Schluchter, Wolfgang. Rationalismus der Weltbeherrschung; p. 12.

53 É interessante observar também que para Weber a ação religiosa é, primordialmente, orientada por objetivos e aspirações mundanas. Os fins transcendentes para um mundo extramundano são resultado de desdobramentos posteriores e muito específicos. Isto porque, em primeiro lugar, das ações mágicas mais primitivas às religiões de salvação, as promessas se orientaram sobretudo por questões eminentemente terrenas, para que "vás muito bem e para que vivas muitos e muitos anos sobre a face da Terra". As religiões primitivas ou cultivadas, as proféticas e as não proféticas responderam sempre às demandas de saúde, de longevidade e de riqueza. De acordo com Weber, mesmo entre as formas de religiosidade cujos bens de salvação seriam de caráter extramundano, a situação apresenta-se de modo muito menos transcendente do que aparenta à primeira vista. Na verdade, os fieis encontrariam o conforto psicológico às suas angústias quando se portavam cotidianamente consoante certos desígnios divinos, ao observarem meticulosamente alguns rituais sagrados, ou se afastarem radicalmente do mundo e de suas ordens. Mais do que a intangibilidade de objetivos que, muitas das vezes, se realizariam apenas após a morte, eram tais práticas que provocavam por elas mesmas os estados e os sentimentos desejados por seus seguidores. O sentido de uma vida religiosa se daria, portanto, pelo significado que determinadas atitudes assumiam aos olhos dos indivíduos. 
tentar descortinar os pressupostos materiais camuflados pelas ideias religiosas - uma abordagem

absolutamente equivocada para analisar o pensamento weberiano -, o objetivo aqui é apenas

apontar a confluência de fenômenos socioculturais variados ${ }^{54}$. Segundo Weber:

Os diversos estados religiosos ou mágicos que imprimiram psicologicamente seu caráter sobre uma religião podem ser sistematizados desde os mais variados pontos de vista. Não é este o lugar de empreender semelhante intento. O que aqui nos interessa, conectando ao que foi dito mais acima, é indicar, de um modo totalmente geral, que o tipo de estado imanente de bem-aventurança ou renascimento a que uma religião aspira como bem supremo tem que ser necessariamente distinto, evidentemente, segundo o caráter do estrato que constituía o sujeito mais importante da religiosidade em questão. As classes dos cavalheiros belicosos, os camponeses, os negociantes, os intelectuais literariamente educados mostram nesse aspecto, como é natural, tendências diferentes, que por si só,s, como se mostrará, estão bem distantes de determinar univocadamente o caráter psicológico da religião, mas que, no entanto, influíram nele de modo durável. ${ }^{55}$

Embora sujeitas a assumir afinidades eletivas com múltiplas formas de religiosidade, de acordo com Weber, as camadas burguesas frequentemente se mostraram mais afins a condutas de vida baseadas em um racionalismo prático e cotidiano. Contrariamente aos camponeses, cuja atividade econômica esteve atrelada à maior dependência das intempéries da natureza e, portanto, tendiam a desenvolver uma religiosidade carregada de elementos mágicos e ritualísticos, os comerciantes, os artesãos, os profissionais liberais sempre desconfiaram, ao menos intuitivamente, que as causas de seu bem-estar e de seus ganhos pecuniários pudessem ser reportadas a atuação de alguma potência misteriosa.

54 É interessante sublinhar que Horkheimer parece compreender a relação entre as religiões e a vida material de uma maneira bastante próxima da weberiana. As ideias religiosas assumem para o frankfurtiano uma legalidade própria que não as reduz à simples mistificação ou falsificação de relações econômicas. Conquanto as últimas sejam determinantes para se interpretar os diferentes períodos históricos e os movimentos sociais em geral, a religião bem como as demais esferas culturais - podem desempenhar, sob determinadas condições sócio-históricas, um papel decisivo para a compreensão da dinâmica social. Segundo Horkheimer: "É verdade que a religião recebe todo o seu conteúdo mediante a assimilação psíquica de acontecimentos terrenos, mas nisto ela adquire sua própria forma, que reage, por outro lado, à predisposição psíquica e ao destino dos homens e constitui uma realidade no conjunto da evolução humana. Vale o mesmo para as idéias de moral, de arte e de todos os outros campos culturais. Embora, por exemplo, a consciência moral, o senso e a concepção do dever tenham desenvolvido uma ligação muito estreita com a coação e a necessidade dos mais diversos tipos e devam mesmo ser interpretadas em larga medida como força interiorizada, como a leis exterior incorporada à alma, elas, no entanto, representam, afinal, na estrutura psíquica dos indivíduos, forças específicas, com base nas quais eles não só se submetem ao existente, mas também, em certas circunstâncias, se opõem a ele.” Horkheimer, Max. “Autoridade e família”; p. 184. Porém, como aponta Lutz-Bachmann, o seu interesse pelas religiões tem objetivos completamente distintos dos de Weber. Segundo Lutz-Bachmann: “A análise de Horkheimer sobre a religião, sobretudo a cristã, percorre o conjunto do seu pensamento e não se separa de sua questão principal. (...). Quando Horkheimer discute o problema do limite da capacidade de conhecimento humano sob o pano de fundo da crítica ao conhecimento de Kant e Schopenhauer, a pergunta sobre a religião é posta; ela mostra-se objetivamente ligada ao problema da verdade, em conexão com o colpso identificado por Horkheimer de toda a possibilidade de metafísica após o fim do sistema da filosofia hegeliana. Quando o problema da filosofia da história e a fronteira de uma fundamentação filosófica positiva da ação é tematizada, a pergunta sobre a religião é levantada.” Lutz-Bachmann. “Humanität und Religion”; p. 108.

55 Weber, Max. "Einleitung”; p. 251. 
Por outro lado e em contraste com as camadas de guerreiros belicosos, o burguês típico nunca sentiu grande necessidade de devotar suas preces contra a irracionalidade do seu destino. Ante o caráter ordinário que marca sua forma de existência, uma atitude economicamente responsável sempre lhe fora mais útil. Os temores advindos das incertezas do desfecho de uma guerra são mais dramáticos e, verdadeiramente, de uma qualidade distinta quando comparado com as agruras que um comerciante pode enfrentar em sua batalha do dia a dia. Bastante distante de qualquer misticismo, é certo que os estratos guerreiros também voltavam seus interesses para uma realidade intramundana. Porém, a sua típica conduta de vida se orienta por outros pressupostos. Face às fantásticas aventuras e aos insondáveis desafios que um herói enfrenta durante sua existência, a capacidade de dominar racionalmente o mundo por intermédio do trabalho parece algo muito menos palpável e bem pouco atraente, quando não indigno e desprezível ${ }^{56}$. A respeito das camadas burguesas, Weber afirma:

Comum a todos estes tipos foi a tendência à racionalidade prática do estilo de vida, condicionada pelo maior aleamento da dependência econômica da natureza. Sua existência inteira repousa sobre a dominação e o cálculo técnico ou econômico da natureza e dos homens, por mais primitivos que sejam seus meios. Também entre eles pôde a técnica de viver herdada se estereotipar no tradicionalismo, como continuamente tem ocorrido por todas as partes. Mas sempre subsistiu entre eles, ainda que fossem em graus muito distintos, a possibilidade de que surgisse uma regulamentação ética racional da vida, em conexão com a tendência ao racionalismo técnico e econômico. ${ }^{57}$

É interesse salientar que Weber diferencia o típico comportamento religioso no interior das classes burguesas. Quanto se constituíra em estratos sociais profundamente privilegiados, a burguesia tendia a se filiar a uma religiosidade bastante próxima à peculiar das camadas guerreiras ou aristocráticas, no que pese os fortes contrastes em um numeroso conjunto de elementos.

O ordenamento ético e sistemático da vida passava tão distante da realidade de sua atividade econômica como as elaborações teológicas a respeito do além de sua conduta religiosa. Os grandes

56 A esse respeito, Weber afirma: "Não é costume a nobreza guerreira e todas as forças feudais tornarem-se facilmente sustentáculos de uma ética religiosa racional. A maneira de viver do guerreiro nem tem afinidades eletivas com a ideia de uma Providência bondosa, nem com a de exigências éticas sistemáticas por parte de um deus transcendente. (...). Aceitar uma religião que trabalha com tais concepções e vergar-se perante o profeta ou o sacerdote tem, forçosamente, que parecer vil e indigno a um herói guerreiro ou a um homem distinto - quer seja o aristocrata romano, ainda no tempo de Tácito, quer seja o mandarim confucionista. Sair vencedor da morte e das irracionalidades de destino humano é para o guerreiro uma questão de todos os dias.”. Idem. "Sociologia das Religiões”; págs. 129-130.

57 Idem. "Einleitung"; p. 256-257. 
comerciantes da Antiguidade e da Idade Média, os portadores de fortunas financeiras exorbitantes, os magnatas mercantis caracterizavam-se sobretudo pela ocasionalidade de um modo específico de ganhar dinheiro, sem desenvolver ou sem se basear no funcionamento regular de uma empresa capitalista moderna $^{58}$. Eles podiam ser fervorosamente religiosos, mas a natureza de sua devoção se voltava exclusivamente a esse mundo terreno e era completamente alheia a qualquer noção profética. A multiplicação de suas reservas se realizava mais pelo financiamento de mercadores viajantes desprovidos de maiores recursos, pelo fornecimento de crédito às metrópoles durante o capitalismo colonial a fim de cobrir os gastos das políticas expansionistas do que pelo modo racional de um empreendimento contínuo e formalmente pacífico de obtenção de lucro. Mesmo quando contemporâneos às modernas seitas protestantes, o comportamento econômico típico da burguesia abastada se vinculava às exigências do capitalismo politicamente orientado, gerando inclusive suspeitas e estranhamentos religiosos mútuos. Segundo Weber:

Os grandes e distintos comerciantes da Holanda protestante eram, na qualidade de arminianos, adversários do rigorismo ético calvinista. Cepticismo ou serenidade forma e são, em toda a parte, uma atitude muito frequente dos grandes comerciantes e grandes prestamistas perante a religião. Cepticismo ou serenidade foram e são, em toda a parte, uma atitude muito frequente dos grande comerciantes e grande prestamistas perante a religião. ${ }^{59}$

Algo sensivelmente distinto se verifica com relação à pequena-burguesia. Portadora de novos e modestos capitais, apenas um comportamento rigorosamente racionalizado e sóbrio - no sentido moderno dos termos - possibilitaria a ampliação de seus parcos recursos. Dedicada principalmente às incipientes indústrias ou ao comércio, a nascente pequena-burguesia urbana ${ }^{60}$ não

58 Idem. "Sociologia das Religiões"; p. 136.

59 Ibidem; p. 137.

60 A especificidade da cidade ocidental é também um elemento essencial para Weber. Existindo em pureza quase típico-ideal ao norte dos Alpes, as cidades ocidentais são provavelmente os locais nos quais a burguesia tenha espelhado e expressado seu estilo de vida do modo mais fiel. Para além de critérios meramente econômicos ou referentes apenas ao maior adensamento populacional, Weber compreende as cidades como um espaço capaz de organizar a vida coletiva de uma maneira bastante particular. como ponto de afluência de forasteiros desde suas primeiras formas de existência, as cidades ocidentais se estruturaram como uma comunidade de relativa acefalia político-administrativa, na qual os membros de clãs das mais diversas origens se viam obrigados a conviver pacificamente entre si. Os elementos mágicos e ritualísticos ligados aos clãs e às tribos ou eram abandonados às portas das cidades, ou eram resguardados à vida privada de seus praticantes. Quando foi verdadeiramente digna de tal termo, a sua vida pública se assentou ao romper com limitações mágicas e religiosas e ao garantir grande igualdade de oportunidades para os seus cidadãos. Contrariamente ao que se passou na China ou na Índia, onde a confraternização entre os habitantes era condicionada pela permanência viva de tabus e de interditos religiosamente orientados, a integração dos cidadãos à comunidade urbana baseava-se em sua qualidade de indivíduos, e não como pertencentes a determinadas tribos ou castas. O cidadão pertencia juridicamente ao seu clã de origem na China e se 
possuía reservas suficientes para a participação nos empreendimentos coloniais, na pirataria, na

grande agiotagem ou nas guerras ${ }^{61}$. Os riscos e as incertezas inerentes ao exercício de tais atividades

lhes era um crasso contrassenso.

O lucro possível só poderia ser conquistado com a rigorosa, intransigente e mesquinha contabilidade, por meio da qual o saldo das vendas deveria superar necessariamente os custos envolvidos. A sua conduta religiosa típica também se deixa perceber por outros fundamentos. A vida sacra e temente a Deus se articula por uma racionalização ética - sistemática e pormenorizada -, cujos princípios norteadores foram estabelecidos por revelações proféticas. Embora as condições gerais de existência da pequena-burguesia não garanta inequivocamente a uma forma racionalizada de religiosidade ${ }^{62}$, na medida em que se conseguiu romper definitivamente com as concepções mágicas e encantadas da relação entre os homens e a divindade, a possibilidade do protestantismo angariar seguidores nesse estrato social foi sempre crescente. Segundo Weber:

Mas a classe pequeno-burguesa tende efectivamente, como se compreende, com relativo vigor - e, na verdade, por razões que se prendem com o seu modo de vida económico - para a religiosidade de ética racional, sempre que se encontrem reunidas as condições da respectiva génese. É evidente que a vida do pequeno-burguês, sobretudo do artesão e do pequeno comerciante urbanos, está muito mais longe da sujeição à Natureza que a dos camponeses, de modo que, para aquele, a dependência da influência mágica exercida sobre os espíritos irracionais da Natureza não pode desempenhar o mesmo papel

via obrigado a observar zelosamente o culto aos seus antepassados. Na Rússia, a imigração da aldeia não eliminava os vínculos jurídicos atrelados à sua condição anterior de camponês. Na Índia, antes de mais nada, a filiação à casta sobrepujava qualquer outro elo especificamente urbano. Qualitativamente diferente de tudo isto, Weber destaca o ritual de comensalidade de São Pedro com irmãos não-circuncisos, destacado pelo apóstolo Paulo na Epístola aos Gálatas, inaugura uma relação nova - e particular ao Ocidente - entre os habitantes citadinos. Segundo Weber: “Na China, foi o clã exógamo e endofrátrico, e na Índia, desde a vitória dos reis patrimoniais e dos brâmanes, foi ainda por cima a casta endógama e exclusiva, em virtude de determinados tabus, que impediam qualquer união dos cidadãos urbanos em uma relação associativa, baseada em igualdade jurídica geral, sacra e civil, em conúbio, comensalidade e solidariedade diante do exterior. (...). Os habitantes de uma cidade indiana não têm nenhuma possibilidade de realizar, como tais, banquetes culturais comuns, enquanto os chineses, em virtude de sua organização em clãs e da importância predominante do culto aos antepassados, não têm nenhum motivo para isto. (...). Ao contrário, já para a polis da Antiguidade, segundo a tradição, um componente do ato (real ou fictício) do calonia (sinecismo) era a substituição dos prítanes individuais, que serviam para os banquetes cultuais das associações acolhidas, pelo prítane da cidade, originalmente indispensável para toda polis, que era o símbolo da comensalidade dos clãs urbanos, como conseqüência de sua confraternização.” Idem. "A dominação não-legítima (Tipologia das cidades)"; p. 429-430.

61 Idem. "Sociologia das Religiões"; p. 138.

62 Segundo Weber: “A mera existência de artesãos e de pequenos burgueses nunca bastou, porém, para dar origem, só por si, a uma religiosidade ética, ainda que de um tipo muito geral. Vimos, pelo contrário, como o tabu das castas conjugado com a crença na transmigração das almas influenciou e estereotipou a ética dos artífices indianos. Somente onde tenha surgido uma religiosidade própria de comunidade confessional - e, em especial, quando esta seja racionalmente ética -, é que, então, ela pôde conquistar adeptos urbanos, como era de supor, e depois, em determinadas circunstâncias, influenciar duradouramente o modo de viver desses sectores. Foi o que aconteceu, efectivamente.” Ibidem; p. 143. 
que para os rurais. E que, pelo contrário, as suas condições de existência económica têm um caráter essencialmente mais racional, isto é, são mais acessíveis ao cálculo e à influência exercida com finalidades racionais. Além disso, a sua existência económica leva o artesão, nomeadamente, e também o negociante, em determinadas condições específicas, a pensar que a honradez é do seu próprio interesse, que o trabalho dedicado e o cumprimento do dever devem encontrar a sua "recompensa” e também "valem” o seu justo salário. ${ }^{63}$

Ora, se Weber correlaciona a forma de religiosidade típica do protestantismo ao modo e ao estilo de vida das camadas pequeno-burguesas urbanas, com Horkheimer a questão se desloca obviamente para um momento histórico posterior. Com o capitalismo tardio, os grupos sociais beneficiados pela exploração do trabalho humano alteraram sua fisionomia. O pequeno empresário do liberalismo foi suplantado por camarilhas de caciques que usurparam os postos de comando nos grandes trustes industriais e nos governos dos diversos estados nacionais ${ }^{64}$. Não obstante as fontes e as vítimas do lucro renovado continuarem as mesmas, a economia já não se dinamizaria preferencialmente pela concorrência entre os proprietários individuais em torno do melhoramento tecnológico dos meios de produção, mas pelo agravamento das tensões internacionais e pelo acirramento do abismo entre as classes sociais no interior das nações ${ }^{65}$.

Embora com uma abordagem um tanto distinta, o frankfurtiano também reconhece a reforma protestante e as suas concepções acerca do trabalho profissional e da disciplina cotidiana como um elemento essencial para interpretar as sociedades modernas. Entretanto, suas considerações apontam

63 Ibidem; p. 141.

64 Em "Kultur und Ideologie", Taubes estabelece uma interessante argumentação pela qual ele visa discutir a maneira que Marx, Weber e Adorno interpretariam a questão da ideologia nas sociedades modernas. Voltarei com mais vagar a esse artigo, mas, por ora, convém trazer à tona um ponto específico. Grosso modo, Taubes afirma que Weber não fora capaz de interpretar verdadeiramente a concretude - isto é, a sua vinculação com a dinâmica das classes sociais - do destino histórico das sociedades capitalistas modernas. Segundo Taubes: “As análises de Weber, mas também a sua prognose, ganham sua força com a constelação da própria sociedade industrial, que tanto no Oriente como no Ocidente intensificou as potencialidades de dominação ao extremo. Seja quando Weber descreve o que é, seja quando sua análise mantinha valor de prognose, seria impossível polemizar contra isso. Outra coisa, porém, é a sua complicidade com o curso da história, que o seduzia a elevar o acontecer ao destino. Weber conhecia exatamente, como testemunha claramente uma carta encontrada em seu espólio endereçada a Robert Liefmann, o espectro de conceitos coletivos. Para Weber, coletivos não são 'nada a não ser as chances, que tipos determinados de ações específicas encontrarem-se com ações de determinados indivíduos humanos. Nada além disso...'. Quem sabe isso, deveria dar os nomes sempre que fala do destino”. Taubes, Jacob. “Kultur und Ideologie”; págs. 129-130. Ao comentar esse mesmo ensaio, Cohn afirma: "Basta ir aos textos para comprovar que a 'dinâmica de interesses' que Weber buscava conhecer para cada caso não pode ser discutida sem 'dar os nomes'. O que se pode questionar aqui é se ele realmente conseguiu das os 'nomes certos' em determinadas análises. E isso é apenas uma maneira de propor a questão mais profunda, sobre se, no seu esquema, Weber tem condições para ir além do ato de 'dar os nomes' em cada caso; pois é disso (que não é simplesmente uma dúvida empírica) que se trata, sobretudo se a crítica busca sua inspiração no marxismo.” Cohn, Gabriel. Crítica e resignação; p. 171-172. Nesse sentido, a questão que me interessa particularmente nesta contraposição é saber se o interesses que Weber afirmou estarem ligados à racionalização ocidental permanecem os mesmos para Horkheimer com o capitalismo pós-liberal.

65 Horkheimer, Max. “Teoria tradicional e teoria crítica”; p. 136. 
para um horizonte bastante distinto do que o encontrado nos escritos de Weber. Tal atitude não se calca em idiossincrasias de um intelectual descontente com o curso do mundo, mas brota da má necessidade da própria coisa. Em face do crescente recrudescimento da vida social com a reposição do rígido princípio de autoridade sustentador da engrenagem econômica capitalista, as concepções protestantes a respeito da sagrada ordenação da vida assumiriam um outro e mais opressivo significado. Já não se trata mais de investigar as condições do surgimento das modernas formas de sociabilidade, mas sim do modo de atuação dos obstáculos para a urgente transformação radical das mesmas. Em “Autoridade e Família”:

O protestantismo ajudou o sistema social em preparação a introduzir aquele sentimento pelo qual o trabalho, lucro e poder de dispor do capital como um fim em si mesmo substituíssem uma vida centralizada numa felicidade terrena ou também celeste. $\mathrm{O}$ homem não deve curvar-se perante a Igreja, como acontecia no catolicismo; deve apenas aprender a curvar-se, a obedecer e a trabalhar. Por isso, a obediência não é mais essencialmente um meio de conseguir a salvação ou não é apenas delimitada firmemente pela ordem terrena, e divina, mas, sob o absolutismo, ela se transforma crescentemente numa virtude que carrega em si mesma o seu valor. A teimosia da criança tem de ser quebrada, e o desejo primitivo de um desenvolvimento livre de impulsos e faculdades deve ser substituído pela obrigação interior de cumprir o dever incondicionalmente. A sujeição ao imperativo categórico do dever foi, desde o início, um objetivo consciente da família burguesa. Se o benefício da educação humanística no Renascimento, que com poucas exceções aproveitava principalmente aos filhos de nobres italianos, aparecia indicar um feliz prelúdio da nova época, então nos países para os quais, após a descoberta da passagem marítima para as Índias Orientais, se transferiu a hegemonia econômica, especialmente na Holanda e na Inglaterra, a infância tornou-se progressivamente mais sombria e mais opressiva. $^{66}$

Diante desse novo contexto socioeconômico, faz-se necessário perscrutar as causas que repõem os mecanismos de autoridade propagados principalmente pelo protestantismo e, ao mesmo tempo, os transformaram em algo ainda mais grosseiro e irracional. A rija crosta de aço que um dia pesou apenas como um leve manto sobre os ombros dos indivíduos mostra uma nova constituição de chumbo. Assumindo as formas de um Deus absoluto e transcendente, o espírito do capitalismo marcou-se no peito dos indivíduos, preparando o terreno para a ascensão de formas autoritárias de governo e perpetuando interesses mesquinhos e inconfessáveis.

Esse acréscimo de irracionalidade se reflete e se impõe por um progressivo descolamento entre o comportamento típico dos sujeitos no capitalismo tardio e os valores forjados com o

66 Idem. “Autoridade e família”; p. 214-215. 
nascimento da burguesia. Para Horkheimer, as ideias e as formas de conduta dos primeiros momentos do capitalismo moderno já eram em si ideológicas. No sentido forte do termo, tratava-se de uma aparência socialmente necessária, que iludia os homens a respeito de seus verdadeiros interesses e das reais condições de reprodução da vida social, mas correspondia de forma imediata à dinâmica das sociedades modernas. Em alguma medida, a crença do empresário em sua capacidade individual, em sua experiência no mercado e em seus conhecimentos sobre a situação econômica e política dos países não eram, em absoluto, integralmente infundadas para garantir o sucesso de seus negócios.

Porém, a situação já não é mais a mesma. A rápida e intensa concentração e centralização do capital, que marca a passagem do capitalismo liberal para o monopolista, não alterou substancialmente as irracionais regras do jogo, mas exacerbou a impessoalidade de todo o processo. Também como antes, os produtos do trabalho humano realizam o seu valor no mercado sem qualquer planejamento racional prévio. Ainda que a economia esteja concentrada nas mãos de um diminuto grupo de executivos e de dirigentes, eles orientam suas ações econômicas unicamente pelas possibilidades de valorização do capital.

As mudanças seriam mais vigorosas nas esferas culturais. Se o pequeno comerciante do liberalismo já transparecia em inúmeros aspectos de sua vida ser simples personificação do capital, os atuais dirigentes dificilmente se deixam reconhecer por traços de alguma personalidade legítima. Concomitante ao descolamento entre a propriedade jurídica dos meios de produção e o controle efetivo sobre os rumos dos negócios, os antigos senhores do mundo viram o seu poder pessoal de ingerência ir à bancarrota pela coisificação plena das relações sociais. Eles permanecem sendo os únicos beneficiados pelo mecanismo de exploração econômica, mas a condição para tanto foi aceitar como legitima a reificação de suas formas de conduta. Segundo Horkheimer:

Na decisão sobre a sorte das pessoas, sobre recrutamento e demissão das massas operárias, arruinamento dos camponeses de comunas inteiras, desencadeamento de guerras etc., o lugar do despotismo não foi eventualmente ocupado pela liberdade, mas pelo cego mecanismo econômico, um Deus anônimo que escraviza os homens e a quem invocam aqueles que, se não têm poder sobre ele, têm pelo menos o benefício dele. Os donos do 
poder cessaram de agir como representantes de uma autoridade mundana e celeste e tornaram-se, portanto, funções da legitimidade de seus fortunas. Os empresários, aparentemente livres, são motivados por uma dinâmica econômica desalmada e não por seu íntimo, como se afirma, e não têm meios de se opor a este estado de coisas, a não ser pela renúncia à existência. A mais completa adaptação possível do sujeito à autoridade efetiva da economia é, ao mesmo tempo, a forma da razão na realidade burguesa. ${ }^{67}$

A dissolução das antigas bases liberais do capitalismo agravou a impotência dos indivíduos diante uma realidade anárquica, dilacerada por contradições sociais e ainda mais desumana. Na filosofia iluminista, conquanto ainda se levantassem vozes pelas quais a recusa da submissão autoritária do passado não se converteu em aceitação do presente, as categorias abstratas de indivíduo e de razão já prenunciavam a incompreensível limitação das concepções burguesas de emancipação e de autonomia. De acordo com Horkheimer, ao menos até o século XIX, a filosofia moderna se alimentou da radicalidade da luta da burguesia contra as relações hierárquicas do absolutismo e contra a burocracia principesca.

O orgulho dessas formulações se transformou em uma desavergonhada glorificação do status quo. Como uma espécie de mau agouro de uma transformação, cuja efetivação na conduta dos homens só fora conseguida pela rispidez de profundas coerções físicas e psíquicas, o pensamento burguês esqueceu-se progressivamente de sua intransigência em favor de uma conciliação com racionalizações das mais abjetas. O contraste entre a razão e a autoridade foi perdendo sua agudeza crítica até culminar no próprio enaltecimento à submissão autoritária. Ao pensar o indivíduo como uma mônada - isolado em si mesmo e dissociado do mundo - o espírito burguês mostrou-se incapaz de avaliar a real dependência que os sujeitos experimentam em suas vidas cotidianas. De maneira complacente e fechando os olhos diante do terrível mecanismo de exploração econômica, preferiu-se deixar os homens entregues a si mesmos com a ingrata tarefa de se conformar a mais dura das lições: a de que aquele que é escolhido pelo destino também é por ele culpado $^{68}$, restando a eles apenas padecer de seus desatinos. Segundo Horkheimer:

O período clássico desta situação expirou, de fato, com o liberalismo, e a capacidade individual de boas previsões quanto às condições do mercado, cálculo e especulação, numa época como a atual, que não se caracteriza mais pela concorrência de inúmeras vidas

67 Ibidem; p. 202.

68 Ibidem; p. 231. 
independentes, mas pela luta de gigantescos trustes monopolistas, se transformaram na ampla mobilização de nações inteiras para conflitos violentos. Contudo, o pequeno comerciante sempre transfere suas próprias dificuldades para os dirigentes do truste industrial. Se ele próprio, na sua posição apertada, já tem de operar contínuas manobras para não afundar, estes, na sua opinião, têm na verdade de ser gênios para agüentar-se em cima. Mesmo que eles próprios possam comprovar com certeza que foram menos aquelas qualidades de seus pais que eles deveriam continuar a desenvolver do que, ao contrário, a firmeza brutal que exige o moderno domínio sobre as massas mediante uma oligarquia econômica e política, de qualquer modo a realidade social não lhes parece clara e compreensível. De um lado, apresentam-se como perigosas as forças naturais, a população do próprio país, bem como os grupos inimigos de poder que se precisa subjugar ou manobrar habilmente para os próprios fins, de outro os mecanismos do mercado mundial não provocam perplexidade menor do que uma concorrência mais estreitamente limitada; e não só propagam a ideologia segundo a qual a atividade dos grandes da economia precisa de instinto genial, com também acreditam nela.

O acanhamento teórico da burguesia anteciparia o recrudescimento nas demais esferas da vida social. O funcionamento da engrenagem político-econômica do capitalismo tardio exige um controle eficaz sobre as massas. A violência da dominação não mediatizada permanece como uma alternativa disponível. Marcada dolorosamente na memória dos indivíduos, a brutalidade da longa história do processo civilizatório ressurge cotidianamente para se manter diferenças de classe e de propriedade. Em um passado não muito remoto, quem não dispunha de meios de produção se via obrigado a vender sua força de trabalho. Caso se contentassem com rendimentos de uma jornada mais amena, os aparatos de repressão eram mobilizados a fim de fazer valer a máxima de que não são deliberações racionais, mas a necessidade cega de um processo de produção e distribuição de bens e mercadorias a responsável pela decisão sobre a melhor maneira de se ganhar a vida.

Execuções maciças de seres humanos acompanharam, pari passu, a formação da categoria de trabalhadores livres. O mesmo indivíduo que a filosofia iluminista apresentava como um sujeito autônomo, livre e cujo comportamento deveria se basear no uso exclusivo da razão, quando pobre e, portanto, sem propriedade de meios de produção - morria mais de trabalho do que de qualquer outra doença ${ }^{69}$. É certo que o seu herdeiro pós-liberal já não padece mais tanto de tais monstruosidades. Mas esse alento não tem nada de nobre. O conjunto da sociedade não apenas aceitou os atuais desmandos, como também convenceu-se da naturalidade e da imutabilidade de sua indecorosa estranheza. Segundo Horkheimer:

69 Ibidem; p. 203. 
Nesta indicação, diante da qual aquelas organizações também tinham de curvar-se, expressar-se o traço característico do sistema vigente, o de que o trabalho, de acordo com seu gênero e conteúdo, não é determinado pela vontade consciente da própria sociedade, mas pelo concurso cego de forças dispersas - a mesma característica que coincide também com a falta de liberdade do próprio empresário. A diferença está em que esta necessidade inconsciente, na qual certamente se inclui, como elemento importante, todo o esforço consciente dos indivíduos e nações, bem como o mecanismo político e cultural, representa, para um lado, a condição de seu domínio, para o outro o rigor do destino. A sujeição às condições econômicas dadas que o trabalhador aceita no contrato livre é, ao mesmo tempo, a sujeição à vontade particular do empresário; o trabalhador, ao admitir a autoridade dos fatos econômicos, reconhece de fato a posição de mando e a autoridade do empresário. Enquanto ele dava crédito às teorias idealistas de liberdade e igualdade e à soberania absoluta da razão, tal com reinavam no último século, enquanto ele se sentia livre sob as próprias circunstâncias dadas, na realidade a sua consciência era ideológica; pois as autoridades não eram derrubadas, apenas se ocultavam atrás do poderio anônimo da necessidade econômica ou, como se costuma dizer, atrás da linguagem dos fatos. ${ }^{70}$

Pois, conquanto a violência aberta não seja um aspecto definitivamente superado nas sociedades modernas, a atual forma de dominação atuaria preferencialmente por mecanismos mais fugidios. Não apenas os homens devem se curvar ante as instâncias de poder, mas também - e talvez principalmente - eles precisam reconhecer nesta irrefletida obediência algum tipo de satisfação subjetiva, ainda que ela expresse o desalento e o desespero de um riso nervoso. Ao menos como ameaça, os horrores da manufatura e do trabalho em minas de épocas não muito distantes continuam a assombrar os trabalhadores.

No entanto, as sociedades se mostram capazes de impor suas premissas também por outras vias. Um consórcio de inúmeras instituições sociais cria e consolida os pressupostos necessários para os indivíduos se submeterem de bom grado a uma figura objetivada de autoridade. Menos pela vontade consciente de seus dirigentes e mais pela indiciosa sedução das condições reinantes, tenta-se ininterruptamente convencer os homens de que o obtuso ordenamento social é o único possível, mesmo que ele se erija pela confluência irracional de processos sociais não controlados. Fazer nascer nas massas o sentimento de reconhecimento da legitimidade de tal situação é o ponto de partida para perpetuar o que há muito tempo se tornou obsoleto. Segundo Horkheimer:

Mas, no curso da evolução - ao menos para certos períodos economicamente marcantes - a crueldade e a publicidade das punições podiam ser abrandadas; sua ameaça foi cada vez mais diferenciada e espiritualizada, de forma que os terrores, ao menos parcialmente, se transformaram em medo e o medo, em cautela. E, assim como nos períodos de ascensão econômica, com o aumento da riqueza social, parte das funções que as punições cumpriam podiam ser assumidas pela sua contrapartida positiva, a expectativa

70 Ibidem; p. 205. 
de recompensa, os senhores e guardiães que já originalmente foram multiplicados, segundo características primitivas do aparelho psíquico, por um exército de espíritos e demônios, converteram-se, em parte, numa deidade ou num ideário, tornado mais sombrio ou mais acolhedor conforme a época. Somente isto já significa que a coação, na sua forma nua, não basta para explicar por que as classes dominadas também nas épocas da decadência de uma civilização, nas quais as relações de propriedade bem como as formas de vida vigentes em geral já se tinham transformado abertamente no entrava das forças sociais, e apesar do amadurecimento do aparelho econômico para um modo melhor de produção, suportam o jugo por tanto tempo. ${ }^{71}$

De acordo com Horkheimer, a história de tal amansamento das populações é longa e sempre dependeu de ensinamentos religiosos. Mesmo antes de Lutero, o cristianismo já creditava à família a tarefa de educar os jovens consoante as exigências de reprodução de um comportamento conformista. Se recomendações como as de Santo Agostinho ainda apresentavam um caráter genérico e aspiravam pela formação de um bom cidadão em vista da necessidade de fundamentar uma relação harmônica entre o Estado e a Igreja, as lições do protestantismo cresceram em clareza e em virulência. O seu significado seria fazer brotar na consciência dos homens uma disposição para suportar uma realidade hostil que não oferece oportunidades para a felicidade.

Examinar os laços construídos no interior da família unicelular burguesa é essencial para se compreender esses fenômenos ${ }^{72}$. Desde os seus primeiros anos, o indivíduo moderno é educado, consciente e inconscientemente, a introjetar e reproduzir os caracteres humanos exigidos para a conservação da ordem social. Pagando o preço de ter de conduzir suas vidas com incomensurável frieza contra si e contra outrem, os homens seriam formados a fim de não se desesperarem ante a dura disciplina do trabalho do capitalismo moderno. A nova forma de autoridade condiciona os sujeitos a agir pelo uso da razão. No entanto, isso não significa transformar a sociedade em algo substancialmente racional. As crianças aprendem que os bons modos correspondem à incondicional submissão aos desmandos e às vontades do pai. Reconhecer com a força do intelecto que as

71 Ibidem; p. 183.

72 A respeito de “Autoridade e família”, Martin Jay afirma: “De maneira breve, Horkheimer reconhecia uma relação dialética entre família e sociedade, por vezes contradizendo, por vezes reforçando a sociedade, mas com este elemento negativo em declínio. (...). A maior implicação deste ensaio, e dos Studien como um todo, foi a transformação do papel da família no processo de socialização. Por conta do declínio da função 'negativa' e contraditória da família, os indivíduos foram socializados mais diretamente por outras instituições da sociedade. (...) estes agentes alternativos de socialização eram instrumentos para a criação de um tipo de 'personalidade autoritária' mais sutil e mais resistente à mudança do que em qualquer sociedade pré-moderna.” Jay, Martin. The dialetical immagination; p. 126-127. 
desigualdades sociais e a recorrente injustiça são condizentes com o único ordenamento possível da vida coletiva é uma lição que se aprenderia bem antes de se frequentar os bancos escolares.

Esse ensinamento não é válido apenas para garantir menos turbulência no círculo familiar. O mesmo tipo de conduta é exigido e replicado nos diversos âmbitos das sociedades. Conhecer racionalmente a realidade existente tornou-se sinônimo de considerar justo e prudente se submeter e respeitar os seus preceitos por mais disparatados que sejam. As ações e as atitudes socialmente estimuladas não são aquelas que aspiram à realização de um juízo moralmente superior, mas sim as que se adaptam sem sobras às circunstâncias. Segundo Horkheimer:

Justamente este conceito objetivado de autoridade é aplicado, na moderna teoria política da autoridade, ao chefe político. O fato de ele, no protestantismo, ficar reservado para a transcendência - o que, sem dúvida, é religiosamente decisivo - não anula a verdade de que ele, como conceito religioso e político, emana da mesma prática social e de a sinceridade para ele, como uma categoria fundamental da interpretação do universo, é produzida necessariamente pelas condições da mesma pequena família patriarcal. ${ }^{73}$

O lastro da figura de autoridade no seio da família moderna assenta-se em dois aspectos fundamentais. Não se admira ou se obedece ao pai porque ele seria digno de respeito, mas por ser o fisicamente mais forte e aquele que ganha dinheiro. A sua capacidade de mando advém unicamente de sua posição social privilegiada e de sua força física. $\mathrm{O}$ amor devotado pela criança faz com que a postura diante da força e da riqueza se transubstancie em uma relação moral. Tal como a concepção protestante de divindade, o poder da figura paterna é absoluto e inquestionável. Seus desígnios não devem ser sequer justificados, pois qualquer passo nessa direção denotaria incontornavelmente colocar em dúvida a própria autoridade com a qual eles se revestem.

Promove-se a difusão de um dos ensinamentos mais fundamentais para a perpetuação do capitalismo. As desigualdades existentes entre os homens são simplesmente aceitas e jamais poderiam ser alteradas, sob o risco de profanar as vontades de Deus ou se chocar com a pretensa objetividade de leis naturais. Mesmo diferenças eminentemente históricas como a distinção entre os ricos e os pobres adquirem a dignidade de terem sido criadas e desejadas por Deus.

A natural condição de menoridade dos primeiros anos de vida das crianças é perpetuada para

73 Horkheimer, Max. “Autoridade e família”; p. 218. 
muito além da juventude. Dotando as relações sociais da mesma qualidade de objetos naturais, o capitalismo moderno difunde uma postura na qual a obstinada dependência parece não poder ser transformada. Em larga escala, a lição que se aprende no interior da família antecipa a estrutura de autoridade da realidade exterior. Se Freud ensina que algo familiar revela uma estranheza capaz de fazer esmorecer o que se apresenta como mais íntimo e pessoal, a pequena família patriarcal moderna parece querer convencer que algo estranho e não natural - as diferenças sociais existentes entre os homens - se deva carregar irrefletidamente no coração. Abandonar-se às idiossincrasias de qualquer chefia é tido como o ideal mais racional a ser perseguido. Segundo Horkheimer:

A objetivação da autoridade encontra sua expressão imediata na concepção protestante de Deus. Não é porque Deus é sábio e bondoso que os homens lhe devem veneração e obediência. Interpretada dessa maneira, entender-se-ia a autoridade como uma relação na qual um se subordina racionalmente ao outro em virtude de sua superioridade objetiva; ela compreenderia a tendência a anular-se a si próprio, porque a obediência afinal libertaria o inferior da inferioridade. Todavia, esta opinião contradiz a prática social reinante, na qual, ao contrário, a aceitação da dependência conduz ao seu contínuo aprofundamento. Na consciência da atualidade, a autoridade também não aparece absolutamente como uma relação, mas como uma qualidade inevitável do superior, como uma diferença qualitativa. Já que o modo de pensar burguês não reconhece o valor de bens materiais e espirituais com que os homens se ocupam diariamente como uma forma de relações sociais, mas como qualidades naturais dos objetos ou, em contrapartida, os subtrai da análise racional como estimativas puramente arbitrárias, ele compreende a autoridade como qualidade fixa, na medida em que, em geral, não é negada anarquicamente. ${ }^{74}$

De acordo com Horkheimer, essa é a maneira pela qual as relações de poder se estruturam no capitalismo tardio. Das situações mais corriqueiras até o centro do poder político, o Deus do calvinismo emprestou a sua forma coisificada de autoridade para assegurar a perpetuação de vínculos hierárquicos injustificados. A mesma fantasmagoria oriunda da troca de mercadorias sustenta a opacidade desse enredo. Como uma cobra dotada de asas que espalha mais e mais o seu veneno, ela se tornou o denominador comum de todas as relações sociais ao extrapolar as barreiras das transações comerciais.

O caráter utilitário e o embotamento das relações mercantis foram transpostos para o íntimo da vida pessoal, para a sensibilidade e para o pensamento dos indivíduos. Essa reverência condena os sujeitos a conviver com uma enfadonha monotonia. De antemão, qualquer experiência se vê

74 Ibidem; p. 217. 
enredada nas malhas desse esquematismo da percepção ${ }^{75}$. Ao reconhecer a atual divisão social do trabalho, a distinção entre os proprietários de meios de produção e o resto da população e a forma pela qual a riqueza material circula e é produzida como natural, os indivíduos modernos aceitam também a maneira pela qual o poder político autoritário funciona e se organiza. Segundo Horkheimer:

Esta complicada estrutura de autoridade teve seu apogeu no liberalismo. Também no período do Estado totalitário, ela constitui uma chave para a compreensão das formas humanas de reação. As relação de dependência na economia, que são fundamentais para a vida social, podem ser derivadas mentalmente outro tanto do Estado; que este seja aceito de modo absoluto pelas massas da população, só é possível enquanto aquelas não se tornarem realmente um problema para elas. Por isso, a tentativa de identificar a atual estrutura de autoridade com as relações entre líderes e sequazes e de unilateralmente tornar fundamental a aceitação desta hierarquia, deve necessariamente fracassar. Ao contrário, a própria relação nova de autoridade, que hoje se situa no primeiro plano do pensamento e do sentimento, só é possível porque aquela outra, mais comum e ao mesmo tempo mais profunda, ainda não perdeu seu poder, um poder que, por outro lado, é certamente apoiado por ela. A liderança política é eficaz, pois grandes massas reconhecem consciente ou inconscientemente ser necessário sua dependência econômica ou, pelo menos, não a compreendem totalmente, e esta situação é consolidada retroativamente pela relação política. ${ }^{76}$

Mais do que apenas iludir as massas a respeito de seus reais interesses materiais, as sociedades modernas conseguem inscrever na natureza humana modos de reação que desempenham uma função de manutenção irrefletida da ordem social. Embora essa natureza não seja pensada por Horkheimer como uma substância primitiva, nem eterna e tampouco uniforme, ela intimida, sufoca e desfigura as tentativas de transformação social profundas. Ante o novo, a reação mais difundida e mais imediata é uma intestina repulsa. Mesmo que a satisfação com ordenamento social seja para lá de duvidosa, os homens parecem preferir reiterar as condições que os levam ao infortúnio e à apatia.

Segundo Horkheimer:

Todavia, enquanto se trata da continuidade de velhas formas sociais, o papel principal não é desempenhado pelas intelecções, mas pelos modos humanos de reação que se consolidaram em ação recíproca com um sistema de instituições culturais na base do processo de vida da sociedade. A elas pertence a capacidade, consciente ou inconsciente, codeterminadora de cada passo do indivíduo, de se adaptar e se subordinar, a virtude de responder afirmativamente a situações existentes como tais no pensar e no agir, de viver da

75 A esse respeito, segundo Horkheimer: "O mundo espiritual, no qual a criança, devido a esta dependência, se engrena, bem como a fantasia com que ela anima o real, seus sonhos e desejos, sua imaginações e juízos são dominados pelo pensamento do poder e do obedecer. Este esquema é uma das formas do entendimento desta época, uma função transcendental. A necessidade de uma hierarquia e divisão da humanidade, baseadas em princípios naturais, fortuitos e irracionais, se torna tão familiar e automática para a criança que ela também pode experimentar, apenas sob este aspecto, o mundo e o universo, mesmo o além; cada nova impressão já é pré-formada por ele.” Ibidem; p. 219-220.

76 Ibidem; p. 207. 
dependência de ordens dadas e vontade alheia, em sua a autoridade como uma marca da existência inteira. Fortalecer no íntimo dos próprios dominados o necessário domínio dos homens pelos homens que determina a forma da história até agora, foi uma das funções de todo o mecanismo cultural das diversas épocas; o resultado é que a fé na autoridade, como condição sempre renovada deste mecanismo, constitui na história um motor humano, em parte produtivo, em parte obstrutivo. ${ }^{77}$

Porém, a vida social é prenhe de reviravoltas estruturais. De acordo com Horkheimer, os fenômenos culturais não se resumem ao papel de conformar os indivíduos à simples aceitação de um processo monolítico. Refletindo tais turbulências, a cultura pode apresentar-se como o elemento desencadeador de situações revolucionárias ${ }^{78}$. Convém voltar as atenções à maneira pela qual a vida cultural poderia fomentar um tipo de comportamento não conformista. Para tanto, uma discussão com a sociologia weberiana oferece uma interessante oportunidade de compreensão de alguns aspectos do pensamento do frankfurtiano. Notadamente no que diz respeito ao diagnóstico weberiano do significado - ou melhor, de sua falta - peculiar às modernas sociedades capitalistas, Horkheimer elabora uma interpretação distinta. Intimamente relacionada a essa questão, será necessário analisar posteriormente a avaliação dos autores sobre a possibilidade da existência de vínculos fraternais entre os sujeitos modernos.

\section{Do sofrimento imerecido...}

Embora o alvo não seja especificamente Nietzsche, mas uma certa psicologia de seu tempo, para Weber a análise sociológica dos fenômenos religiosos não se coaduna a uma interpretação fundamentada no conceito de ressentimento. Uma ligação direta e tão imediata entre as doutrinas religiosas e os grupos sociais nos quais elas encontram seus seguidores poderia, por um lado, corresponder sim à satisfação de uma necessidade psicológica bastante geral e abstrata - por exemplo, uma espécie de teologia da felicidade, na qual os afortunados buscam se convencer da legitimidade de seus privilégios. Salvo essa concessão, ela giraria no vazio em tantos outros

77 Ibidem; p. 191.

78 A esse respeito, segundo Jay: “A cultura, afirmavam Horkheimer e colegas, nunca era epifenomênica, embora tampouco fosse inteiramente autônoma. Sua relação com a subestrutura material da sociedade era multidimensional. Todos os fenômenos culturais eram mediados pela totalidade social, e não apenas reflexos de interesses de classes. Isso significava que eles também expressavam as contradições do todo, inclusiva as forças que negavam o status quo.” Jay, Martin. The dialetical imagination; p. 98. 
momentos numerosos e essenciais. Se a irmandade surgida por meio da sublevação dos escravos, como o produto do sentimento de vingança dos desfavorecidos, poderia soar plausível numa primeira aproximação e para seitas e dogmas específicos, os fenômenos religiosos das mais variadas civilizações abarcam um conjunto de circunstâncias muito mais intrincado ${ }^{79}$.

As múltiplas torções pelas quais a noção de sofrimento passou ao longo da história das religiões universais e o fenômeno das racionalizações religiosas permaneceriam incompreensíveis sob essa perspectiva. Imaginar a existência de vínculos inequívocos e imediatos entre as classes sociais e as crenças, os ensinamentos e as práticas religiosas seria desmentido historicamente na quase totalidade dos casos. Em "Einleitung”:

A racionalização não somente não tem absolutamente nada a ver com o ressentimento. Pelo o que se refere à valorização do sofrimento nas éticas religiosas, não há dúvida de que se vê submetida a uma evolução típica que, bem entendida, outorga uma certa justificação à teoria que Nietzsche formulou pela primeira vez. A primitiva atitude ante o sofrimento se manifesta plasticamente, ante tudo, no trato que recebiam, durante as festas religiosas da comunidade, aqueles em quem assola enfermidades ou quaisquer outras desgraças duradouras. Quem padecia de sofrimento duradouro por luto, enfermidade ou qualquer outra desgraça era considerado, segundo a espécie desta, ou como possuídos por um demônio ou como castigados pela cólera de um deus ao que haviam ofendido. Para a comunidade de culto poderia ter consequências desvantajosas os tolerar em seu seio. Em todo caso, não os permitia tomar parte nos sacrifícios e banquetes rituais. Pois sua presença não alegrava aos deuses e poderia excitar sua cólera. Apenas os venturosos teriam assento nos banquetes sacrificiais, inclusive na época do sitio de Jerusalém. ${ }^{80}$

Na verdade, o que se deve ter em vista são as diversas reações teológicas ante a recorrente disjunção entre o que é oferecido pelas religiões de salvação e por aquilo que os seus fieis clamam, isto é, como preencher a exasperante distância de um deus sempre tão longe dos gemidos e das lamúrias de seus seguidores. Os efeitos das inúmeras concepções teológicas na conduta de vida prática dos indivíduos, que visavam regulamentar de forma positiva os princípios regentes no mundo e em suas ordens, se tornam compreensíveis apenas por essa via. Da atitude inicial de considerar o acometido de enfermidades ou desgraças duradouras como um possuído cuja

79 Na verdade, as críticas de Weber a Nietzsche reconhecem, em alguma medida, a influência que o ressentimento desempenhou na formação sobretudo do cristianismo. O equívoco de Nietzsche residiria em assumir esse traço cultural - que não conseguiria nem explicar toda a complexidade do cristianismo - como o principal fator de articulação dos sistemas religiosos. Segundo Weber: "A teodiceia do sofrimento pode ter uma matriz de ressentimento. Mas a necessidade de uma reparação da insuficiência do destino nesse mundo, não somente não tomou sempre essa matriz como característica fundamental e decisiva, como também não a adotou em nenhuma vez de forma regular.” Weber, Max. "Einleitung”; p. 247.

80 Idem. "Einleitung”; p. 241-242. 
participação nos cultos da comunidade deva ser impedida, passando por experiências glorificadas de mortificações e abstinências do corpo como meios de despertar estados sagrados até se chegar à noção pela qual o pecado é entendido como falta de fé no profeta ou em seus mandamentos, pouco a pouco, foi se tecendo um conjunto de práticas rituais e elaborações teóricas aspirando regular as relações entre os homens e os poderes sobrenaturais ${ }^{81}$. As disputas entre as comunidades de culto tradicionais e as novas profecias acarretaram não só uma transformação na maneira pela qual a influência mundana se efetivara sobre a orientação e o conteúdo dos dogmas religiosos, mas também orientaram as tentativas de dotação de um significado para o mundo.

O deslocamento que ora se observa entre atender aos interesses da totalidade social - as súplicas pela chuva e o sol, a caça, a vitória sobre os inimigos ${ }^{82}$ - no primitivo culto da comunidade para a atividade do pastor das almas cuja atuação ia ao encontro da redenção do sofrimento individual é acompanhado pelo surgimento de uma espécie de teodiceia do sofrimento. Se, num primeiro momento, a necessidade de justificar a felicidade incentivara o desdobramento de concepções e de ideias religiosas, numa etapa posterior, é a própria infelicidade que requer uma explicação teológica. Mais prenhe de consequências para o destino das religiões universais, essa nova disposição desencadeia um movimento bastante amplo de eticização e de racionalização das doutrinas religiosas. Segundo Weber:

Essa religiosidade pressupunha o mito de um redentor, quer dizer, uma consideração ao menos relativamente racional do mundo, cujo objeto mais importante que o constituía, por sua vez, era o sofrimento. Seu ponto de partida esteve com frequência na primitiva mitologia da natureza. Os espíritos que governavam o ir e vir da vegetação e o curso dos astros associados com as estações se converteram nos representantes favoritos do mito do deus que sofria, morria e ressuscitava e que garantia também aos homens em sua miséria o retorno da felicidade imanente ou a segurança da transcendência. Também se converteram em objeto de um fervoroso culto de salvador figuras das sagas heroicas incorporadas às tradições populares, as que, como Krishna na Índia, se dotava de mitos da infância, amor e guerra. Um povo politicamente oprimido, como o dos israelitas, aplicou primeiramente o nome de salvador (moschuach) aos libertadores da prostração política (Gedeón, Jefté) nas tradições das sagas heroicas, definindo com sua imagem as promessas "messiânicas”. Foi com esse povo, e com tão grandes consequências somente com ele, onde, em condições muito particulares, o sofrimento de uma comunidade nacional, e não o do indivíduo, se converteu em objeto de esperanças de redenção religiosa. A regra havia sido que o salvador tivesse ao mesmo tempo caráter individual e universal, de modo que estivesse pronto para

81 Idem. ES; p. 281.

82 Idem. "Einleitung"; p. 238. 
garantir a salvação do indivíduo e de todo indivíduo que se dirigisse a ele. ${ }^{83}$

Concomitante a essas tentativas de racionalização do mundo, esbarrou-se reiteradamente em um substrato arredio a esse tipo de arranjo. Weber parece mirar a compreensão da dinâmica de um processo histórico realizado quase a contrapelo. O mais importante seria precisamente aquilo que se dá às margens dessas respostas. Diante de um mundo organizado e que se reproduz a partir de relações de dominação - as quais, apenas furtivamente, comportam-se segundo critérios de equidade e de justiça - as religiões da salvação obrigaram-se a formular justificativas e explicações teológicas cada vez mais complexas e universalizantes para, entre idas e vindas, manterem-se fieis a alguma coerência lógica interna.

Quanto mais sublimada e internalizada se considerava a essência do sofrimento, maior era a tendência em articular os ensinamentos religiosos em um sistema e, com isso, a salvação deixa de ser concebida como um estado de êxtase agudo e extraordinário tornando-se um problema a se enfrentar pela elaboração de um hábito sagrado permanente. Segundo Weber:

Ao aumentar a racionalidade do ponto de vista ético-religioso e ir-se eliminando as primitivas ideias mágicas, a teodiceia tropeçou neste tema com dificuldades crescentes. A desgraça individual "imerecida” era demasiado frequente. Não somente do ponto de vista de uma "moral de escravos", mas também segundo as próprias pautas do estrato dominante, era demasiado frequente que não lhes ia melhor os melhores, mas sim os "piores”. Como explicações do sofrimento e da injustiça apareceram os pecados cometidos pelo indivíduo em uma vida anterior (migração das almas), ou a culpa dos antepassados, que se paga até a terceira e à quarta geração, ou, em um sentido mais de princípio, a podridão de toda criatura enquanto tal; como promessas de compensação se ofereceram as esperanças em uma vida futura melhor, seja neste mundo para o indivíduo (migração das almas) ou para seus sucessores (reino messiânico), seja no além (paraíso). De modo semelhante, a ideia metafísica de Deus e do Mundo produzida pela criação de poucos (no total, segundo veremos, três) sistemas de pensamento que deram respostas racionalmente satisfatórias à questão do fundamento da incongruência entre o destino e o mérito: a doutrina indiana do Karma, o dualismo zoroástrico e o decreto de predestinação do Deus Absconditus. ${ }^{84}$

A questão do sofrimento imerecido manifesta-se não apenas como pólo propulsor de ações mágico-religiosas, mas também como o elemento que escancara seus limites. Diante da constância da manifestação desse núcleo irracional, uma das mais recorrentes alternativas oferecidas pelas religiões de salvação erigiu-se em uma concepção dualista de mundo, divisada entre uma moralidade interna e outra externa. Vínculos de piedade eram reservados para as relações instituídas

83 Ibidem; p. 244.

84 Ibidem; p. 246-247. 
no interior do círculo comunitário-religioso, e as relações com todos os demais eram inapelavelmente condenadas à observar as leis da fria necessidade econômica e os dispositivos impessoais da política.

O arranjo, no entanto, mostra-se instável e as obrigações morais de reciprocidade foram sucessivamente desafiadas pelas ordens do mundo. Na medida em que a vida em sociedade se diferenciava, o desafio de manter ligações fraternas entre os habitantes de uma mesma comunidade torna-se um problema agonizante. De forma recorrente, cristaliza-se uma situação de tensão arraigada e contínua dos elos existente entre os irmãos de fé com as distintas esferas da vida social. Com a modernidade capitalista, a disjunção entre os compromissos de fraternidade e os requisitos e os objetivos da vida mundana não só se manteve viva, como reposicionou a sua antinomia em níveis cada vez mais elevados.

Em "Consideração intermediária", Weber destaca nos diversos campos da vida social processos análogos - respeitando, cada qual suas especificidades históricas e sociais - de autonomização relativa das esferas de valor, por meio da qual a cultura moderna se constitui como uma realidade inerentemente conflitual. As esferas econômica, política, estética, erótica e intelectual, paulatinamente, foram se desdobrando e se afastando mutuamente entre si - como consequência, passaram a ser governadas segundo critérios baseados em suas respectivas legalidades próprias ${ }^{85}$. Racionalizadas em várias direções e sob diferentes pontos de vista, Weber distingue a ação de um processo que desencadeou a atualização de um antigo conflito. A tensão entre a ética fraternal e as ordens do mundo secularizou-se e internalizou-se nos próprios indivíduos

85 Segundo Schluchter: "Weber fala, portanto, no capítulo 'ética religiosa e 'mundo' da ética de convicção religiosa, na 'Consideração intermediária' da ética de fraternidade das religiões de salvação, que estão em conflito com o 'mundo'. Mas o conflito dissolve esse 'mundo' nas conhecidas esferas de valor e ordens de vida e, com isso, liga-se a formas fundamentais de condutas de vida. Ele se coloca individualmente e não em sua generalidade contra os postulados religiosos. Os possíveis conflitos entre as esferas 'mundanas' e as ordens de vida podem também se manter ocultos. Esse conjunto de confrontações puseram em cena tanto o objetivo, como evidenciaram o modo especial dos aspectos gerais do conflito possível entre a 'religião' e o 'mundo'. Cada esfera de valor e ordem de vida tem os seus pressupostos e condições especiais, vincula a ação a valores e meios específicos , que pode ter como efeito um conflito especial entre a ética religiosa e o 'mundo', um conflito surgido da rejeição antieconômica, antipolítica, antiestética, antierótica e anti-intelectual do mundo.” Schluchter, Wolfgang. Religion und Lebensführung 2; págs. 76-77. 
modernos ${ }^{86}$.

O comportamento econômico do mercado, os compromissos e responsabilidade do Estado moderno, as questões concernentes à avaliação e ao gosto estético, o desatino e o caráter descomedido do amor sexual e as regras do conhecimento intelectual descolaram-se da necessidade de libertação do sofrimento e da injustiça que, em outros contextos, eram sistematizadas pelas religiões da salvação. É como se o desenvolvimento autônomo dessas esferas dilacerasse a sociedade e os indivíduos por meio das suas reivindicações e de suas recompensas peculiares e, por vezes, antagônicas. Fundamentalmente moderno - ou seja, desencantado - trata-se da emergência de um novo “politeísmo de valores”. Segundo Weber:

Religiões de profetas e salvadores, tendo como pressuposto óbvio o que acabou de se dito, viviam, em grande e historicamente muito importante parte dos casos, numa relação de tensão aguda (como é óbvio, segundo a terminologia aqui adotada) e permanente com o mundo e suas ordens. Quanto mais salvadoras as religiões, maior a tensão. Isso decorria do sentido da salvação e da essência da doutrina profética salvadora, à medida que seus princípios evoluíam para uma ética racional e orientada por bens de salvação interiormente religiosos como instrumentos de redenção - isto é, quanto mais ela, no sentido corriqueiro da palavra, era sublimada - do ritualismo para a "religiosidade de convicção". A tensão se tornou tanto mais forte quanto mais, do outro lado, a racionalização e a sublimação da posse exterior e interior dos bens "mundanos" (no sentido mais amplo) também progredia. A racionalização e a sublimação conscientes das relações humanas com as diferentes esferas de posse de bens, exteriores e interiores, profanos e religiosos, obrigou o homem, segundo leis próprias interiores de cada uma das esferas, a se conscientizar das consequências de suas ações e, com isso, fez com que entrassem em tensão aquelas que permaneciam a salvo da ingenuidade natural da relação com o mundo exterior. ${ }^{87}$

Absolutamente desamparados, os indivíduos modernos devem fazer frente às exigências do

dia. Isto é, aguentar, virilmente e sem lamentos, a severidade do destino das paixões na modernidade. O que não equivale dizer, necessariamente, agir de forma mecânica e sem alma ${ }^{88}$.

86 É preciso salientar ainda que as religiões da salvação entraram em um estado de tensão duradoura com tudo aquilo que nunca lhes foi alheio - o mundo e suas ordens. Seja pela regulamentação dos vínculos de piedade e de obrigação de ajuda econômica aos mais necessitados, seja pela íntima relação entre os deuses funcionais com a comunidade social e política correspondente, ou também por meio da orgiástica mágica e pelo elevado desenvolvimento artístico patrocinado pelas instituições religiosas, as religiões da salvação sempre se sentiu impelida a dar um significado ético a essas esferas.

87 Weber, Max. “Consideração intermediária”; p. 512-513.

88 A esse respeito, segundo Jessé Souza, Weber em “A ciência como vocação” e “A política como vocação”: “Nos dois textos, vocação tem o mesmo sentido de renúncia e autocontrole que possibilitam a unidade da personalidade e a consequência na ação. Foram essas duas características que impressionaram Weber na condução da vida do puritanismo ascético. Na sua versão secular, no entanto, a ideia de vocação é depurada a partir do seu entrelaçamento com as noções de individualismo ético e de responsabilidade em direção a um estágio de consciência qualitativamente superior. A crença, nessa versão secular, não deve mais ser a crença ingênua do puritano, mas sim uma tomada de posição em relação à realidade como ela é. O especialista com espírito distingue-se pela criação autônoma de valores, afastando-se da heteronomia típica à relação religiosa.” Souza, J. Patologias da modernidade; p. 121. 
Como se fossem homens de ciência, os descaminhos do acaso, o grau extremo de especialização das funções, a impenetrabilidade e a ausência completa de clemência por parte das instituições burocráticas expõem as condições básicas a serem suportadas pelos sujeitos. Estes, sem poder contar com as garantias e sem se comprometer com os limites que as demais visões religiosas do mundo implicavam, laçam-se a um mundo sem sentido, no qual se é possível constatar apenas o funcionamento de mecanismos de causalidade sem qualquer significação transcendente. Sem a pretensa eternidade e segurança dos antigos deuses, a modernidade ocidental põe-se em cena como uma realidade marcada essencialmente pelo conflito e pela cisão.

Se não inexistentes, as rotas alternativas são certamente estreitíssimas. Os sujeitos modernos governam suas ações consoante anseios e julgamentos mais íntimos e profundos. Entretanto, independentemente do alto grau depositado na crença de seu valor, eles não conseguem ultrapassar o fato de que cabe a qual determinar o que é seu deus e o que é o diabo ${ }^{89}$. A ausência de sanção e reconhecimento social não fez com que as reivindicações de renúncias e de imolações dessas divindades mundanas sejam menos ouvidas ou atendidas. À parte “crianças grandes” que continuam reivindicar e acreditar que a ciência - ou outra esfera da vida social - seja capaz de restabelecer algum significado para o mundo, a cada nova geração esse indômito tormento se atualiza. Com as portas das velhas Igrejas fechadas para quem não deseja - ou não consegue - efetuar o sacrifício do intelecto exigido, a única saída possível é agir no mundo com convicção, tendo sempre em vista um responsável cálculo de prós e contras de suas atitudes, mas sem alimentar ilusões de qualquer tipo de recompensa necessária ou justa. Segundo Weber:

Qual é, afinal, nesses termos, o sentido da ciência enquanto vocação, se estão destruídas todas as ilusões que nela divisavam o caminho que conduz ao "ser verdadeiro", à "verdadeira arte", à "verdadeira natureza", ao "verdadeiro Deus”, à "verdadeira felicidade”? Tolstói dá a essa pergunta a mais simples das respostas, dizendo: ela não tem sentido, pois que não possibilita responder à indagação que realmente importa - "Que devemos fazer? Como devemos viver?”. De fato, é incontestável que resposta a essas questões não nos é tornada acessível pela ciência. Permanece apenas o problema de saber em que sentido a ciência não nos proporciona resposta alguma e de saber se a ciência poderia ser de alguma utilidade para quem suscite corretamente a indagação. ${ }^{90}$

89 Weber, Max. “A ciência como vocação”; p. 42.

90 Ibidem; p. 35-36. 
É interessante analisar a maneira pela qual Horkheimer em “Autoridade e família” encaminha uma discussão sensivelmente semelhante, mas com preocupações e com uma interpretação que se distancia da weberiana. É certo que o frankfurtiano não visa discutir pormenorizadamente os móbiles internos do pensamento religioso e de sua racionalização subjacente. Se para Weber o sofrimento imerecido é o elemento central para se compreender o desdobramento interno das ideias religiosas, Horkheimer enxerga a questão de maneira radicalmente distinta.

Porque se já houve na história da humanidade um período no qual a distribuição entre o mérito e a felicidade pudesse ter sido mais equânime, ao se eleger como critério único de justiça a sentença cega da economia, as sociedades capitalistas pós-liberais exacerbaram ao absurdo as diferenças de ganho entre as classes, condenando a maior parte da população à uma miséria injustificada e sufocando inúmeras vocações e faculdades humanas. Recoberta pelo manto de uma suposta necessidade natural, a injustiça geral já não seria mais censurável ou corrigível por ameaças das consequências de uma vida perdida no pecado e nem pelas promessas de redenção no céu dos bem-aventurados ${ }^{91}$. Os pré-requisitos de uma existência confortável na Terra se desprenderam completamente dos esforços e do empenho dos indivíduos, refugiando-se unicamente na boa sorte de uma herança generosa, nas incongruências da situação do mercado de trabalho e no caráter fortuito das cotações de bolsas de valores. Segundo Horkheimer:

Já que, com a crescente irracionalidade do sistema, aquelas aptidões, de resto especiais e isoladas, que antes ainda ofereciam certas chances de progresso e fundamentavam mal a fable convenue do justo acordo entre prazer e trabalho, se tornam cada vez mais indiferentes aos fatores externos do destino pessoal, é cada vez mais evidente a desproporção entre a vida confortável e a escala de qualidades humanas. Enquanto, no quadro de uma sociedade justa, a parte de cada um naquilo que ela consegue adquirir da natureza baseia-se em princípios racionais, aqui ele está entregue ao acaso, e o reconhecimento deste acaso é idêntico à idolatria do mero sucesso, este Deus do mundo moderno. Ele não tem qualquer conexão lógica com um esforço que ultrapassa o dos outros em vigor, inteligência e progresso; o simples fato de alguém o ter alcançado, de alguém ter dinheiro, poder, relações que o elevam acima dos outros, é que coage os outros ao seu serviço. ${ }^{92}$

Ante essa recorrente distribuição desigual entre mérito e felicidade, Horkheimer se debruça

91 Horkheimer, Max. "Autoridade e família”; p. 210.

92 Ibidem; p. 210. 
sobre o sentido que tal repartição pode assumir para os indivíduos modernos. O papel da cultura também aqui é fundamental. Diretamente, a forma pela qual os homens vivenciam a experiência do sofrimento assume uma posição chave para sua a interpretação a respeito das relações entre as bases econômicas e as esferas culturais nas sociedades capitalistas. As formações culturais das mais variadas sociedades prestam um indispensável serviço à conservação das relações sociais dominantes. Porém, a maneira pela qual o sofrimento é percebido pelos sujeitos pode fomentar comportamentos disruptivos e corrosivos no interior das relações sociais ${ }^{93}$. Segundo Horkheimer:

O fato simples de que, nos tempos modernos, o homem ter posses devido a uma circunstância externa lhe confere uma ascendência sobre os outros reduz a uma posição secundária todas as outras ordens de valores que são cotadas na vida pública e nela desempenham um papel. Os grupos sociais que se devem arranjar com a realidade existente e esperam melhorar sua posição dentro dela mantêm a fé na necessidade desta relação fundamental, mesmo que ela há tempos se tenha transformado numa algema. Deve haver uma autoridade “qualquer”, e com isso se referem não tanto à verdadeira autoridade que se baseia nos bens pessoais, mas à autoridade pública, que os força à subordinação ao Estado e lhes tira a decisão. O esforço para manter esta convicção e estendê-la tanto quanto possível à população inteira ocupa todas as esferas da vida espiritual. Seu resultado, a afirmação da hierarquia social estabelecida e do modo de produção no qual ela se esteia, assim como todos os impulsos psíquicos e formas de consciência ligados a esta afirmação se incluem entre aqueles elementos espirituais pelos quais a civilização se mostra como argamassa de um edifício social com fortes rachaduras. ${ }^{94}$

Ao contribuir para o fortalecimento da crença na legitimidade das relações de autoridade, as

esferas culturais surgem como um obstáculo às demandas de transformação social profunda.

Enquanto os indivíduos continuarem a devotar suas almas aos objetivos condizentes com as formas

de dominação consolidadas, as sociedades permanecem a funcionar consoante os seus injustos critérios. Nem mesmo uma profunda mudança na divisão do trabalho e na organização da economia seria capaz de, por si só, alterar imediatamente os rumos de um ordenamento social ${ }^{95}$. Os exemplos

93 Convém ressaltar um desacordo com a leitura de Habermas das relações entre Horkheimer e a sociologia weberiana. Se ambos os autores caracterizam as sociedades modernas como culturalmente ausente de sentido, as consequências que eles desdobram desse diagnóstico são opostas. Enquanto para Weber a tendência mais evidente seria um aprofundamento ininterrupto da burocratização e da rotinização das relações sociais, para Horkheimer o desenlace poderia ser, esperançosamente, outro. A experiência de ausência de sentido poderia desencadear outro significado: o abandono de formas arcaicas de sociabilidade e o surgimento de um mundo verdadeiro novo e humano.

94 Horkheimer, Max. “Autoridade e família”; p. 212.

95 Segundo Horkheimer: "Relaciona-se também com isto a idéia do cutural lag (atraso cultural). Ela entende que, atualmente, a vida social depende de fatores materiais e as esferas relacionadas diretamente com a economia se transformam mais rapidamente que outras áreas culturais. As atuais condições da China e da Índia não provam, entretanto, (...), que a dependência ocasionalmente se altere, mas apenas que a entrada de um novo modo de produção costuma ser travada em primeiro lugar por fatores culturais que estão ligados ao antigo, de modo que ela é precedida de algumas lutas no campo intelectual.” Ibidem; p. 189. 
históricos da China e da Índia, onde as relações culturais arraigadas resistiram à penetração do estilo de vida e das formas de sociabilidades europeias, advertem o quão intrincado e suscetível a inúmeras variáveis é a vida coletiva.

Ao fim e ao cabo, é bem verdade que a economia é o aspecto mais importante e, sob determinadas condições, decisivo para a organização das sociedades. Contudo, investigar demoradamente as esferas culturais muitas vezes constitui também um fator imprescindível para compreensão da dinâmica social. Diferentemente do que se pode ser levado a acreditar, a resistência que civilizações milenares como a chinesa e a indiana demonstraram não se originariam do suposto caráter economicamente mais vantajoso de seus respectivos modos de produção, mas sobretudo pela viva força da tradição.

A maneira de conduzir e de reproduzir a vida foi plasmada em costumes e práticas sociais. Menos do que uma atitude consciente e racionalmente orientada é o medo de se libertar dos limites de um mundo antigo que desempenha o papel de maior importância. Apavorados pelas incertezas do novo, em vez de se rebelarem contra as opressões cotidianas os homens tendem a desejar a realidade com a qual convivem diariamente - mesmo que as recompensas prometidas não satisfaçam a ninguém ou se encontrem postergadas para o além-túmulo. Segundo Horkheimer:

Para indicar como uma forma cultural, depois que se difundiu uma vez, é conservada sempre resistente a partir de uma nova fonte, basta aqui um breve testemunho. "O que, no fundo, causa revolta contra o sofrimento não é o sofrimento em sim, mas a falta de sentido do sofrimento.” Estas circunstâncias levam, segundo Nietzsche, à descoberta da origem da religião. As terríveis diferenças no modo de trabalho e de existência em que se desenvolve o processo indiano de vida, aquela sociedade interpretou através da idéia da migração das almas, segundo a qual o nascimento dentro de uma casta superior ou inferior seria conseqüência de ações de uma vida anterior. Resulta daí, para as camadas inferiores, uma razão especial para não desejar qualquer mudança do sistema. Por mais que o pária possa dizer a si mesmo que obedece fielmente aos preceitos, ele espera também elevar-se, na próxima reencarnação, à casta dos brâmanes e gozar de seus privilégios. ${ }^{96}$

A situação poderia ser completamente distinta. Afora momentos absolutamente raros e passageiros, nos quais a decadência econômica e a fragilidade dos grupos dominantes se sustentam apenas pela força das armas, examinar as esferas culturais como componentes ativos no interior do processo social não significa necessariamente um posicionamento contemplativo perante a história.

96 Ibidem; p. 187. 
Embora o regime social predominante nas sociedades capitalistas dê mostras de conduzir ao seu colapso por causas imanentes, nem por isso a atual situação indica um afrouxamento das formas culturais que sustentam o envelhecido ordenamento social.

As incontáveis renúncias e os sacrifícios cotidianos infligidas nos indivíduos pelo processo de trabalho e pela distribuição de riquezas são refletidas sucessivamente nas esferas culturais. Também como sedimento de antigas e de novas esperanças mantidas vivas, de anseios postergados, mas nunca silenciados, a religião, a arte, a filosofia adquirem certa autonomia em relação às condições materiais das sociedades modernas e são capazes de apontar para um mundo radicalmente novo. Não obstante o caráter utópico e sectário que se assume ao imaginar que alterações em um ponto específico sejam capazes de desencadear isoladamente transformações substantivas na totalidade social, reconhecer e se indignar contra a crueldade da sociedade existente é uma condição prévia para que os homens não abdiquem de buscar satisfação de demandas e de desejos que se choca com aquilo que é permitido pela norma social. Segundo Horkheimer:

Além disso, por exemplo, a regulamentação das relações sexuais no quadro das uniões sexuais, da família, é condicionada pela economia e, em parte, foi imposta de maneira cruel. Apesar disso, o amor romântico nascido no curso desta regulamentação constitui um fenômeno social capaz de levar o indivíduo à oposição ou, mesmo, à ruptura com a sociedade. A união, de modo nenhum natural, mas historicamente desenvolvida, entre a sexualidade e o carinho, entre a amizade e a lealdade, que nos homens se converte em natureza, está incluída entre aqueles elementos culturais que podem desempenhar um papel próprio em certos desenvolvimentos sociais. (...) Se, porém, fatores culturais em todo o processo social, no qual eles decerto estão inteiramente entrelaçados, adquirem um significado próprio, de forma a atuarem como traços de caráter dos respectivos indivíduos, então as instituições baseadas neles e criadas para reforçá-los e continuá-los têm, com maior razão ainda, uma certa legitimidade, embora apenas relativa. Não só a burocracia do aparelho coercitivo do Estado, como também o elenco de todas as instituições culturais em sentido mais estrito têm seu interesse e seu poder. ${ }^{97}$

De toda forma, o descontentamento não deve se limitar a uma crítica superficial às formas culturais vigentes. É premente ir fundo em seus pressupostos materiais mais arraigados. Caso contrário, o protesto torna-se um grito de desespero diante de uma realidade impassível. De acordo com Horkheimer, se tais anseios se resignam com o que é disponível, o seu potencial disruptivo é embotado já no nascedouro. Por mais uma vez, fecha-se o viciado círculo de submissão social. O

97 Ibidem; p. 184. 
protesto que acompanha toda e qualquer reivindicação por relações mais humanas não pode ter na fábula de Antígona o seu modelo a ser seguido.

O conflito com o mundo deve encontrar um outro desfecho para além do representado pela irmã que revela a iniquidade de sua dor no velório do irmão morto. A dialética já não mais precisa conviver com os mesmos desenganos dos quais padecia a sua versão idealista. Sabedor de que a efetividade da emancipação social depende da transformação radical das condições materiais, um desenlace qualitativamente superior é distinguível apenas por meio da transição à uma forma mais elevada de vida coletiva. A respeito da maneira que Hegel especulou acerca dessa questão, Horkheimer afirma:

Todavia, a única coisa que resta à família desesperada, quando o marido amado, a mulher, a criança são destruídos por este mecanismo desumano, "sua atuação positiva e moral contra o indivíduo”, ela se realiza no velório e no enterro e não, por exemplo, no trabalho em prol da melhoria das péssimas condições. A família, ao casar "o parente com o regaço da terra”, desfaz aquela injustiça "de tal maneira que aquilo que aconteceu é antes uma obra, a fim de que o ser, o último, seja também algo desejado e, assim, agradável”. Hegel viu o conflito entre a família e a autoridade reconhecida publicamente sob a figura de Antígone, que luta pelo cadáver do irmão. A relação entre irmão e irmã era, para ele, a coisa mais pura na família. Se ele tivesse descoberto que esta relação humana, na qual pode "o elemento do ego individual cognoscente e reconhecido... afirmar seu direito”, não só é obrigada a submeter-se ao presente no luto pelo morto, mas também pode adquirir uma forma mais ativa no futuro, então sua dialética, com sua forma fechada e idealista, teria certamente rompido seus limites socialmente condicionados. ${ }^{98}$

Idealista, essa tentativa de conciliação é, a um só tempo, liberal e autoritária. Se o tribunal do mundo é o curso da história, essa coleção mal-ajambrada de iniquidades dotadas arbitrariamente da dignidade de algo imutável, não resta outra alternativa aos indivíduos senão superar os possíveis incômodos de harmonizar seus sentimentos, suas vontades e suas aptidões à mesquinhez da realidade cotidiana. Hipostasiar uma forma social na qual os indivíduos aparecem como entes isolados, para quem resguardar a liberdade interior seria a única utopia possível, significa ignorar as diabruras do terrível mecanismo de exploração atuante e, verdadeiramente, fazer ouvidos de mercador às incessantes súplicas de homens concretos $^{99}$.

98 Ibidem; págs. 227-228.

99 A esse respeito, Martin Jay ressalta a influência de Schopenhauer no pensamento de Horkheimer. Ater-se ao sofrimento individual concreto assumiria às formas de uma rejeição radical ao momento ascético das filosofias idealistas e do próprio protestantismo. Tal postura de Horkheimer seria também um modo de se contrapor à celebração anti-individualista de Lukács presente em sua concepção do proletariado como meta-sujeito da história. Segundo Jay: “Apesar de sua distância da limitação das filosofias utilitárias do auto-interesse, ele concedia uma 
Para superar esse estado de coisas é preciso resolver na efetividade social a contradição agarrada ao conceito burguês de autoridade. Uma advertência obrigatória é não se seduzir pela falsidade da abstrata rejeição representada por uma atitude anárquica. Negar imediatamente qualquer princípio de autoridade, acreditando ser possível realizar a liberdade plena num único ato de vontade, mostra-se mais afeito à autoconfiança burguesa e desconsidera a importância das condições materiais ${ }^{100}$.

Na verdade, é imprescindível desassociar as funções diretivas e executivas tanto da atual relação de classes quanto da maneira de distribuir a riqueza material. Se as sociedades do futuro se organizarão também por relações de autoridade, estas, no entanto, não persistirão na tacanhez de sua forma atual. No lugar de perpetuar injustiças e garantir a continuidade da dominação do homem sobre o homem, elas se estabelecerão por meio de interesses substancialmente racionais. Somente assim, não se estará mais a mercê de uma economia cujos benefícios são concentrados nas mãos de poucos, enquanto o restante - a imensa maioria - se vê obrigada por sua pobreza à se submeter mecanicamente ao descalabro de uma injustiça sem sentido. Segundo Horkheimer:

Se, de fato, a sociedade e o Estado de sua época, que não respeitam a personalidade do indivíduo, mas sem mantêm totalmente indiferentes a ela, personificam a justiça, então a redução dos indivíduos a meros representantes de uma função econômica é filosoficamente enaltecida e eternizada. O indivíduo, tal como ele de fato vive e sofre, ou seja, "a singularidade de uma natureza que se torna finalidade e conteúdo", não vale apenas na sua limitação atual, mas pura e simplesmente como "algo impotente e irreal”, e a satisfação dos homens específicos, naturais, isto é, dos homens realmente existentes, constitui, em vez de meta da política, a tarefa puramente espiritual do espírito absoluto, a realização da arte, religião e metafísica. ${ }^{101}$

\section{... à uma nova fraternidade?}

Novamente, faça-se necessário retornar a Weber. Ante o conjunto recorrente de antinomias entre os vínculos religiosos fraternais e as ordens do mundo, Weber acredita que haveria apenas

certa legitimidade ao conceito burguês de egoismo com suas demandas de gratificação pessoal. Como um resultado disso, ele condenava a identificação do trabalho com uma apoteose ontológica da ética do trabalho como quinta-essência do homem. A tradição hedonista na filosofia, que Marcuse discutiu com alguma profundidade na Zeitschrift, deveria ser entendida como um corretivo à indiferença idealista com respeito à felicidade corpórea. Na verdade, a real essência do materialismo, quando corretamente compreendido, seria um protesto contra a negação de gratificação pessoal. Nada seria mais condenável no holismo orgânico contemporâneo do que sua específica justificação do auto-sacrifício heroico em nome do todo.” Jay, Martin. Marxism and totality; p. 212.

100 Horkheimer, Max. “Autoridade e família”; p. 212.

101 Ibidem; p. 227. 
duas posturas coerentemente racionais. A primeira caracteriza-se por uma profunda e irreversível fuga do mundo. As práticas e as doutrinas religiosas místico contemplativas são seu exemplo mais bem definido. A atitude típico-ideal do místico compreende-se como uma espécie de possessão divina. A fim de garantir sua salvação, o agente imagina-se como um recipiente passivo que pretende se conformar superficialmente ao mundo e às suas ordens. Muito menos do que uma atividade mundana, trata-se de uma renúncia ao mundo, realizada pelo seu total afastamento e abandono. A salvação religiosa se efetiva contra a ação intramundana, isto é, com um peculiar recolhimento taciturno e resignado, aspirando cumprir os desígnios divinos justamente pela radical não participação em suas ordens. O que se valoriza religiosamente é precisamente aquilo que se passa aquém ou além da vida social. A sua peculiar rejeição ao mundo é tomada em seu sentido mais literal.

Uma atitude igualmente coerente se deixa apreender pelo conceito de ascese ativa ${ }^{102}$. Contudo, a sua renúncia ao mundo se dá precisamente pelo oposto da experiência místico contemplativa. Também aqui há uma impiedosa desvalorização das variadas esferas da vida social. Entretanto, o seu sentido é absolutamente diverso. Se o asceta ativo reconhece na vida social apenas as chagas da corrupção e da inessencialidade de toda criatura, sua reação é converter-se em um instrumento para a realização da vontade de Deus. A salvação se dá pela peculiaridade de sua ação. O asceta ativo ambiciona curvar a degeneração mundana por sua atividade e pelo seu próprio trabalho. Não que espere atingir com suas obras algo digno da magnanimidade divina. O mundo não é capaz de oferecer nada que valha a pena. Aspirar qualquer satisfação mundana seria a mais improba das condutas. O seu objetivo deve ser tão somente martelar a palavra divina, embora sabedor de que nunca se ultrapassará a baixeza de sua incontornável situação de criatura. Em "Consideração intermediária":

102 É preciso lembrar que, como tipos ideais, Weber exagera na caracterização de seus traços a fim de compor conceitos capazes de apreender a complexidade do real, sem no entanto se confundir com ele. Dessa forma, não apenas o grau de coerência desses conceitos polares não se encontram na realidade, como também é bastante plausível uma espécie de contaminação entre eles. Sem descer aos pormenores dessa questão, é igualmente provável que a rejeição do místico possa desenvolver uma atitude ativa com relação ao mundo quanto a do asceta desembocar em uma contemplação passiva. 
Para escapar, por princípios e interiormente à tensão, houve apenas dois caminhos coerentes. Primeiro, o paradoxo da ética vocacional puritana, que, na forma de religiosidade de viruoses, abriu mão do universalismo do amor, objetificou racionalmente todo agir no mundo como serviço para atender a vontade de Deus (em seu último sentido absolutamente incompreensível mas o único reconhecível como vontade positivista de Deus) e à verificação do estado de graça. Com isso, o puritanismo também acabou por aceitar como vontade de Deus - e como instrumento para o cumprimento do dever - a objetificação do cosmo econômico, desvalorizado, com o mundo todo, em sua condição criatural e corrompida, material. Isso representou, em última instância, a rejeição - por princípio - da salvação como objetivo alcançável pelo homem e para qualquer homem em favor da graça não fundamentalmente, mas sempre exclusivamente particular. Na verdade, tal posição de "desfraternidade" não era mais "religião de salvação" propriamente dita. ${ }^{103}$

Calcada na ascese intramundana, o Ocidente forjou uma religiosidade na qual a renúncia ao mundo não significou o seu abandono. Com o protestantismo, implodiu-se a recorrente antinomia entre manter-se fiel aos preceitos religiosos ou aceitar uma maior participação nas ordens mundanas. Renunciando ao universalismo do amor e com sua peculiar sobriedade, os embebidos nos princípios da ética ascética puritana puderam orientar suas ações conforme a racionalidade própria das diversas esferas da vida em sociedade. É importante ressaltar que o próprio pensamento religioso atuou, sob determinadas circunstâncias, como um processo desencadeador de impessoalização e de objetivação das relações sociais. Aqui, as ideias religiosas não tiveram apenas um papel negativo de ser meramente indiferente às ordens do mundo e contribuíram decisivamente para esse desdobramento. Ao permitir que as condutas dos indivíduos se orientassem por critérios surgidos no interior dos variados âmbitos da vida social, essa concepção radicalmente individualista da salvação desatou os nós que freavam a autonomização das esferas de valor ${ }^{104}$. Finalmente, o mundo ficou à mercê da criatura, mas porque os desígnios de Deus situam-se em uma distância inatingível.

Com isso, Weber afirma que já não se está diante de uma real religião da salvação. Os

103 Weber, Max. "Consideração intermediária”; p. 517-518.

104 Esse desenlace se ensaiou, ao menos de forma latente, mesmo antes da reforma protestante. As religiões da salvação sempre se viram desafiadas pelas ordens do mundo. O protestantismo, porém, foi capaz de efetivar uma alternativa que não implicava na relativização de seus dogmas e princípios e tampouco criava barreiras ou tabus em torno de certas atividades mundanas. De acordo com Schluchter: "Embora a tradição cristã tenha também contrariado essa tendência pela relativização e por compromissos, a possibilidade de colisão total entre os postulados religiosos e o 'mundo' permaneceu sempre que a racionalização das imagens de mundo entrou em cena. Weber já chama atenção para essa possível colisão mesmo antes do que o significado histórico-cultural atingido por ela com o protestantismo ascético. Sua 'história' é descrita a partir das luzes geradas por três eventos: fora concebida com a fundação da confederação judia e com a comunidade da eucaristia na Antioquia, mas veio ao mundo com a reforma protestante.” Schluchter, Wolfgang; “Die Paradoxie der Rationalisierung”; p. 22. 
vínculos fraternais, nos quais as comunidades religiosas normalmente se assentam, perdem significado no protestantismo, principalmente com o calvinismo e suas doutrinas da predestinação, do particularismo da graça e sua concepção de Deus como uma figura pessoal e absolutamente transcendente. Ao despojar a vida religiosa de qualquer meio mágico de salvação, os protestantes já não têm mais à sua disposição qualquer atalho que permita perdoar uma existência condescendente às fraquezas humanas. A condenação é peremptória.

Em uma época na qual os perigos do inferno atemorizavam verdadeiramente, a única alternativa possível se baseia em uma tétrica renúncia de todos os prazeres e de toda recompensa disponível na Terra. Tal postura possibilitou articular a vida em torno de um princípio racionalmente coerente, e cobriu com um turvo pano preto aquilo que algum dia pôde proporcionar alegria e alento aos indivíduos. Se essas foram algumas das condições necessárias para a acumulação de recursos materiais, não é de se estranhar que, ao mesmo tempo, a promessa de felicidade retirou-se completamente do horizonte. Em A ética protestante:

\begin{abstract}
No assunto mais decisivo da vida nos tempos da Reforma - a bem-aventurança eterna - o ser humano se via relegado a traçar sozinho sua estrada ao encontro do destino fixado desde toda a eternidade. Ninguém podia ajudá-lo. Nenhum pregador: pois somente o eleito é capaz de compreender spiritualiter \{em espírito\} a palavra de Deus. Nenhum sacramento: pois os sacramentos, com certeza ordenados por Deus para o aumento de sua glória e sendo por conseguinte invioláveis, não são contudo um meio de obter a graça de Deus, limitando-se apenas a ser, subjetivamente, externa subsidia \{auxílios externos\} da fé. Nenhuma Igreja: pois embora a sentença extra ecclesiam nulla salus implique como sentido que quem se afasta da verdadeira Igreja nunca mais pode pertencer aos eleitos de Deus, resta o fato de que também os réprobos fazem parte da Igreja (externa), mais que isso, devem fazer parte dela e sujeitar-se à sua disciplina, não para através disso chegar à bem-aventurança eterna - isso é impossível -, mas porque, para a glória de Deus, eles devem ser além do mais obrigados pela força a observar os mandamentos. E, por fim, nenhum Deus: pois mesmo Cristo só morreu pelos eleitos, aos quais Deus havia decidido desde a eternidade dedicar sua morte sacrificial. [Isto: a supressão absoluta da salvação eclesiástico-sacramental (que no luteranismo de modo algum havia se consumado em todas as suas consequências) era absolutamente decisivo em face do catolicismo. Aquele grande processo histórico-religioso do desencantamento do mundo que teve início com as profecias do judaísmo antigo e, em conjunto com o pensamento científico helênico, repudiava como superstição e sacrilégio todos os meios mágicos de busca da salvação encontrou aqui sua conclusão. ${ }^{105}$
\end{abstract}

O mundo legado aos últimos homens, os “especialistas sem espírito, os gozadores sem coração» ${ }^{106}$, poderia sim ser completamente outro, no entanto a sociologia weberiana não permite

105 Weber, Max. A ética protestante e o “espírito” do capitalismo; p. 95-96.

106 Ibidem; p. 166. 
especulações a esse respeito. Na verdade, as sociedades modernas revelam-se como o ponto mais alto de um processo trágico que acompanharia de forma latente a humanidade desde sua saída do ciclo orgânico da vida. Mais profunda do que a forte tendência de intensificação de relações impessoais e burocratizadas que se distingue ${ }^{107}$, a própria possibilidade do mundo social significar algo além de um lugar da imperfeição, da injustiça, do sofrimento e da efemeridade parece ser uma quimera. Qualquer vínculo que sugira algum sentido para o acontecer no mundo tem de se haver, reiteradamente, com um desmentido empírico evidente a todos. A insensibilidade do cosmos econômico objetivado, essa forma mais racional de fornecimento de bens materiais, a brutalidade e a distorção da objetividade próprias ao relacionamento sexual bem como os demais aspectos com os quais os elos de fraternidade entraram em irremediável tensão se associariam não apenas à especificidade histórica das religiões examinadas, mas à própria disposição de por em marcha um mecanismo de recompensas eticamente coerentes.

Não que o encadeamento peculiar ao Ocidente tenha sido necessário. Mas, a partir do momento em que as esferas sociais de valor se diferenciaram e passaram a ser governadas consoante critérios imanentes, haveria reduzidíssimas alternativas. Ou a racionalidade substantiva se impunha e inibia o desenvolvimento da racionalização formal, ou esta última tomaria o controle da vida social para si, dissolvendo qualquer pretensão de sistematização ética. Em "Consideração intermediária":

107 De acordo com Weber, uma alteração profunda do regime de propriedade e da forma de administração da economia estaria nesse mesmo movimento de burocratização social. Ao menos no que diz respeito ao seu conceito de socialismo moderno, a atual divisão social do trabalho, que implica na separação do operariado dos meios de produção, sobreviveria ainda que o capitalismo de economia privada fosse dissolvido. Em seu bojo, a rígida disciplina do trabalho fabril e a divisão entre tarefas executivas e gerenciais se manteriam vigentes - e se aspergiriam para todas as demais atividades - mesmo que a planificação da economia sobrepuje a anarquia da produção. A respeito das consequências que a participação na primeira guerra mundial traria para a sociedade estado-unidense, que não seriam muito distantes dos desdobramentos de uma vitória do socialismo em continente europeu, Weber afirma: "Esta Guerra terá como consequência para a América o desenvolvimento de uma burocracia, e com isto chances para o avanço dos círculos universitários - uma consequência natural. Uma europeização da América se dará no mínimo na mesma velocidade em que se falava de uma americanização da Europa. A democracia, em todos os lugares onde é uma democracia de grandes Estados, é uma democracia burocratizada. E precisa ser assim, pois ela substitui os elegantes funcionários honorários aristocráticos e outros por um funcionalismo remunerado. Isto acontece por toda parte, e o mesmo acontece dentro dos partidos. Isto é inevitável e esta realidade é a primeira com que também o socialismo deve contar: a necessidade de uma longa formação profissional, uma especialização cada vez mais profunda e a direção nas mãos deste funcionalismo especializado. Outra maneira não há para dirigir a economia moderna.”. Idem. “O socialismo”; p. 257. 
Toda a "cultura” parecia, vista assim, uma ação em que o homem sai do ciclo organicamente predeterminado da vida natural. Justamente por isso era amaldiçoada a tornar-se uma ausência de sentido cada vez mais aniquiladora a cada passa dado adiante. E o servir aos bens culturais, quanto mais transformado numa tarefa sagrada, numa "vocação", tanto mais condenado a tornar-se uma corrida afobada por objetivos sem valor e, além disso, amplamente contraditórios em si e antagônicos entre si. ${ }^{108}$

Por seu turno, Horkheimer reconhece a possibilidade de um futuro bem mais auspicioso. Além de sua função de condicionar os homens ao princípio de autoridade vigente, a família moderna representaria um refúgio e uma promessa de uma condição humana melhor. As saudades que se sente da infância, o modo pelo qual em alguns momentos a mãe se dirige aos filhos, o amor protetor da esposa com relação ao marido são não apenas um conforto à brutalidade da vida social, mas sim uma espécie de alternativa - frágil e incerta - ao descalabro da situação reinante. Para ser verdadeira, a transição a uma sociedade emancipada precisa enxergar nesses aspectos a dignidade de algo racionalmente superior.

Mesmo sendo incipiente e precário, o afeto que sobrevive em meio aos vínculos familiares mantém viva a esperança. Ao lado de contradições sociais cada vez mais intoleráveis, ao sugerir que o objetivo das relações pessoais possa ser o desenvolvimento de uma real felicidade, tais elos afetivos denotariam que a superação das formas de sociabilidade existentes não se caracterizam unicamente pelos devaneios de uma fantasiosa utopia. Em “Autoridade e Família”:

Tanto quanto os outros elementos do atual contexto cultural, encontra-se a família diante deles como do todo numa relação não só fomentadora, mas também antagonista. Se, mesmo no auge da ordem burguesa, a vida social se renovou apenas sob as maiores privações para a maioria dos homens, então a família era um lugar onde o sofrimento livremente manifestado e o interesse lesado dos indivíduos encontrava um refúgio para a resistência. A transformação do homem na economia em mera função de uma grandeza econômica, do capital, ou de um trabalho manual ou intelectual exigido pela técnica, de fato continua também na família, na medida em que o pai se converte num provedor, a mulher num objeto sexual ou numa escrava doméstica e os filhos em herdeiros da fortuna ou em garantes vivos dos quais se espera que devolvam mais tarde com juros todos os trabalhos despendidos. No entanto, ao contrário do que acontece na vida pública, o homem, dentro da família onde as relações não se processam por intermédio do mercado e os indivíduos não se enfrentam como concorrentes, sempre teve a possibilidade de atuar não só como função, mas também como pessoa. Enquanto a vida burguesa o interesse comum, mesmo quando não é mediado por acordo, como em catástrofes naturais, guerras ou o abafamento de revoluções, ostenta um caráter essencialmente negativo e se manifesta na defesa contra perigos, ele adquire uma forma positiva no amor sexual e, sobretudo, no carinho materno. ${ }^{109}$

Porém, é a infelicidade que sobressai diuturnamente. O protestantismo procurou abafar com

108 Idem. "Consideração intermediária”; p. 548-549.

109 Horkheimer, Max. “Autoridade e família”; págs. 225-226. 
mistificações qualquer espaço de ar livre. O custo de representar certo alento fora cobrado na forma de uma condenação medieval. Marcada indelevelmente com a culpa pelo pecado original, a submissão da mulher ao homem é tratada como natural. Contraponto à forma de domínio atuante na família patriarcal, a feminilidade fora também estigmatizada pela caça às bruxas, a mais execrável forma de racionalização que se exerceu contra um grupo sexual ${ }^{110}$.

Quando o mundo se organiza a partir do poder físico e político dos homens e da irracionalidade da disparidade econômica entre classes sociais, qualquer elemento não plenamente adaptado a tais requisitos padece de caracterizações aviltantes.

A mulher é vista como detentora de uma natureza ardilosa, indecorosamente sedutora e perversa. A odiosa reverência dispensada às mulheres na época de cavaleiros e trovadores ainda não fora rompida. Se a condição para que figurassem como o mais belo ornamento das festas era a subordinação ao domínio do pai, o moderno matrimônio só as cobre de loas quando firmam um pacto jurídico que, não raramente, torna suas vidas em um amontoado de renúncias. Dependentes e sujeitas às vontades do marido, a mulher se vê impedida de se realizar completamente, perdendo sua alma e colecionando frustrações e desamores. Segundo Horkheimer:

Se com isso a família atual, por força das relações humanas determinadas pela mulher, constitui um reservatório de forças de resistência contra a total desumanização do mundo e contém um elemento antiautoritário, certamente a mulher, graças à sua dependência, mudou sua própria maneira de ser. Ao se colocar social e juridicamente sob a tutela do homem e ao depender dele, experimentando, portanto, em si própria a lei desta sociedade anárquica, sua própria realização está sendo continuadamente bloqueada. O homem, e nomeadamente aquele marcado pelas circunstâncias vigentes, domina-a de duas maneiras: porque a vida social é gerida essencialmente pelos homens e porque é o homem quem preside a família. ${ }^{111}$

Em “Consideração intermediária”, Weber tematiza sobre uma questão semelhante. Examinar a especificidade da relação de tensão entre as esfera sexual e as éticas fraternais parece revelar o encontro com uma realidade mais fluida e desafiadora.

Maior força irracional da vida, o amor sexual entra em tensão profunda com as éticas religiosas da fraternidade. Diferentemente da economia, da política e da ciência, não se trata de uma 
disputa que se dê no estrito campo da razão, mas uma refugiada nos interstícios entre o corpo e a alma. As éticas fraternais religiosas sempre reconheceram na vida sexual uma ligação intestina que os homens manteriam com animalidade e que, por isso, deveria ser sumariamente silenciada. O espírito que vence as tentações mundanas encontra nas seduções da carne o seu pior e mais ferrenho antagonista. Dar vazão a essas pulsões por meio de uma carapaça racionalizada e utilitária parece ser uma concessão que o Ocidente sentiu-se obrigado a realizar.

$\mathrm{Na}$ verdade, a monogamia castiça e orientada exclusivamente a fins reprodutivos se aproximaria de uma espécie de doutrina do mal menor. Ela age para que os seus fiéis mantenham algum controle sobre aquilo que é capaz de levar a uma embriaguez tida como eticamente irresponsável e irracional. Em "Consideração intermediária":

A ascese racional intramundana (ascese de vocação) só pode aceitar o matrimônio racionalmente regulamentado como uma das ordens divinas para a criatura irremediavelmente corrompida pela "concupiscência". É necessário viver segundo as finalidades racionais prescritas no interior (e somente nele) de tais ordens divinas - geração e educação de filhos e o apoio mútuo no estado de graça. A ascese racional intramundana deve rejeitar todo requinte do erotismo como divinização (da pior espécie) da criatura. De sua parte, ela insere a sexualidade originadamente natural, camponesa e não sublimada numa ordem racional do criatural: todos os componentes "de paixão", porém, são considerados resíduos da queda da humanidade pelo pecado. Diante deles, segundo Lutero, Deus 'faz vista grossa", para evitar coisas piores. ${ }^{112}$

Pois a sexualidade pode desencadear um devotamento insuportável para as éticas religiosas de fraternidade. Principalmente quando suscita a sensação de pertencimento a uma mesma comunidade, a esfera política concorre com as religiões da salvação por também dotar de significado a morte e a vida humanas. Sobretudo quando sublimada em erotismo, a esfera sexual parece oferecer algo semelhante e, talvez, mais arrebatador. O encantamento ${ }^{113}$ posto em cena pena

112 Weber, Max. “Consideração intermediária”; p. 539.

113 "Nenhuma comunhão erótica completa conseguirá entender a si mesma de maneira diferente do que provocada, e com isso (num sentido diferente do que provocada, e com isso (num sentido inteiramente desprovido de ética) 'legitimada', senão por meio de uma misteriosa situação em que 'um está determinado para outro': destino, na mais elevada acepção do termo. Mas para a religião da salvação esse 'destino' nada mais é que o mero acaso do eclodir de uma paixão. A possessão patologicamente assim criada, idiossincrasia e deslocamento do discernimento e da justiça objetiva, deve lhe parecer a mais completa negação do amor fraterno como A obsessão patológica assim instaurada, a idiossincrasia, a modificação da intuição empírica e de toda a equidade objectiva têm, forçosamente, que se lhe afigurar como a mais completa renegação de todo o amor fraterno e da sujeição a Deus. Sentindo-se como "bondade", a euforia do amante feliz, com a sua amável necessidade de atribuir também expressões fisionómicas alegres a toda a gente ou, num ingénuo empenho em fazer a felicidade de outrem, de as obter por encanto, depara sempre, por isso, com o frio escárnio da ética da fraternidade radical, ingenuamente fundamentada no plano religioso (o que se encontra, por exemplo, nas passagens psicologicamente mais coerentes das obras de juventude de Tolstoi)”. Ibidem; págs. 345-346. Sobre essa passagem, Ao usar um termo encantamento, que também 
sexualidade não apenas se contrapõe à frieza das regulamentações racionalizadas, como também contradiz o amor pensado a partir de categorias religiosas ${ }^{114}$.

A especificidade da relação entre os amantes é a única coisa que importa. Tudo o mais se torna irrelevante para aqueles que vivem uma situação na qual os participantes veem a unidade de suas individualidades se desvanecer, de forma imediata e avassaladora, em uma fusão com o outro. Em oposição a tudo que seja objetivo, racional ou universalizável, a comunhão se estabelece diretamente nas almas dos envolvidos. É aquela pessoa - ou conjunto de pessoas - naquele momento único que satisfaz desejos concretos e determinados.

O amor e a fraternidade religiosas se caracterizam por outros pressupostos. Seja na devoção mística, seja no cristianismo, o sentimento promovido é qualitativamente distinto do que o experimentado em uma relação erótica. Trata-se de uma concepção acósmica de amor na qual o objeto da afeição é o que menos importa. É completamente indiferente a sua natureza, as suas peculiaridades ou mesmo se há ou não correspondência de afetos - é uma espécie de amor em si e por si mesmo.

Para tal relação se efetivar há implícita uma abstração radical da individualidade e da concretude dos sujeitos e de seus desejos. Trata-se da condição de uma afabilidade que não brota da estima e da consideração por si e pelo outro, mas de uma benevolência incondicional. Segundo

em alemão contém a mesma raiz da noção de desencantamento do mundo, Pierucci destaca a possibilidade de pensar por meio das análises weberianas um desenlace superior - na medida que permitiria um espaço para reencantar ao menos as relações afetivas - para o mundo moderno. Segundo Pierucci: "Esse achado, tão inesperado quanto bem-vindo, no fundo uma investigação, não modifica nada do que foi dito neste livro acerca da conceitualização weberiana do desencantamento do mundo. Mas dá um insight dos mais instigantes acerca da possibilidade efetiva, e isto num nível que realmente importa, de reversão subjetiva desse 'grande processo histórico-religioso de desencantamento do mundo que teve início nos profetas do judaísmo antigo'. (...). A crer em sua Consideração intermediária, o locus da existência humana em que se esgueira uma possibilidade efetiva de encantar novamente o mundo não é a esfera religiosa, mas uma outra esfera cultural, ao mesmo tempo não-religiosa e não-racional: a esfera erótica, onde reina, segundo Weber, a 'potência mais irracional da vida' - o amor sexual.” Pierucci, Flávio. O desencantamento do mundo; págs. 220-221.

114 De acordo com Schluchter: “O conceito de mística permanece ainda dentro das coordenadas, que precisamente já estavam postas na primeira edição da 'Ética protestante': de um lado, a ação ascética e, de outro, o sentimento místico. Mas, enquanto a ação ascética, seja ela orientada intramundana ou extramundanamente, é uma rejeição do mundo, o sentimento místico liga-se a uma fuga do mundo. Fuga do mundo significa, ao mesmo tempo, a dedicação a qualquer outro homem, apenas porque ele por acaso esteja lá. Nesse sentido, o cristianismo, visto como tipo-ideal, conhece duas posições extremas: de um lado, uma postura de fuga do mundo própria ao amor acósmico místico e, de outro, uma sacralização ascética do trabalho no mundo.” Schluchter, Wolfgang. Religion und Lebensführung 2; p. 83. 
Weber:

Para uma religião assim só havia a exacerbação da fraternidade à forma que representa de modo bem puro o acosmismo do amor do místico pelo homem. A ele e por ele, essa fraternidade se sacrifica, não mais questionando uma "bondade" que em última instância não está mais preocupada com ele, e de uma vez por todas dá a camisa, onde é exigido o casaco, a qualquer um que por acaso lhe cruze o caminho - uma peculiar fuga do mundo, na forma de uma entrega desprovida de objeto, a qualquer um, não pelo homem, e sim pela entrega enquanto tal. Nas palavras de Baudelaire, pela santa prostituição da alma". 115

Porém, não é esse tipo de redenção que interessaria a Horkheimer. A impessoalidade de um amor sem objeto não baliza uma sociabilidade emancipada. Se para Weber a relação concreta de dois amantes parece encerrar suas potencialidades na incomunicabilidade da vivência experimentada $^{116}$, o frankfurtiano aposta em um outro desfecho. Não se trata apenas de reconhecer na vida sexual um campo no qual os desejos humanos se chocam violentamente com a racionalização predominante nas sociedades modernas. De acordo com Horkheimer, nem mesmo uma sociedade emancipada conseguirá por um termo ao conflito entre as pulsões humanas e as normas sociais.

Porém, tal como o conceito de autoridade, que adquiriria um conteúdo qualitativamente distinto na medida em que contribua para o desenvolvimento de faculdades humanas e não como um elemento que prolonga a injustificada dependência entre os homens, essa relação com as pulsões sexuais deveria se orientar por conteúdos verdadeiramente racionais. Isso significa libertar as pulsões da ignóbil repressão que visa dar guarida à reprodução cega das contradições sociais vigentes.

A vida sexual poderia, assim, deixar de ser apenas um reservatório de energias utópicas ou uma forma de consolo às opressões da vida cotidiana. Caso a humanidade tenha forças para transformar de maneira decisiva a estrutura básica da vida social, a sexualidade não seria mais o alvo de uma cultura repressiva e tornar-se-ia um espaço no qual uma concepção substancialmente racional da vida coletiva abriria possibilidades de uma existência mais prazerosa e menos recoberta de culpas. Em "Autoridade e família":

115 Weber, Max. “Consideração intermediária”; p. 518.

116 Ibidem; p. 344. 
Mas a mulher não só exerce desta forma direta uma função fortalecedora da autoridade, mas também toda a sua posição dentro da família unicelular tem necessariamente, como conseqüência, um aprisionamento de importantes energias psíquicas, que poderiam beneficiar a reestruturação ativa do mundo. A monogamia na sociedade masculina burguesa pressupõe a desvalorização do prazer oriundo da mera sensualidade. Por isso, não só a vida sexual dos esposos é envolta em mistério perante as crianças, mas de todo carinho dispensado à mãe pelo filho tem de ser banido estritamente qualquer elemento sensual. (...). A forçosa distinção, exigida pela própria mulher e, ainda mais, defendida enfaticamente pelo pai, entre a entrega idealista e o desejo sexual, entre o pensamento amoroso e o simples interesse, entre o afeto etéreo e a paixão terrena, constitui uma raiz psíquica na existência cindida por contradições. Se o indivíduo sob a pressão das relações familiares não aprende a reconhecer e respeitar a mãe na sua existência concreta, ou seja, como este ser social e sexual determinado, ele não só é educado para dominar seus impulsos socialmente nocivos, o que tem um significa cultural imenso, mas também , por se processar esta educação de maneira problemática, velada, via de regra o indivíduo considera perdido para sempre o uso de uma parte de suas forças psíquicas. ${ }^{117}$

117 Horkheimer, Max. “Autoridade e família”; págs. 230-231. 


\section{Cap. 2 - O desencantamento do mundo como mito. Crítica à dominação da natureza em cena.}

"Não é mais nada do que determinada relação social entre os próprios homens que para eles assume a forma fantasmagórica de uma relação entre coisas. Por isso, para encontrar uma analogia, temos de nos deslocar à região nebulosa do mundo da religião. Aqui, os produtos do cérebro humano parecem dotados de uma vida própria, figuras autônomas, que mantêm relações entre si e com os homens. Assim, no mundo das mercadorias, acontece com os produtos da mão humana. Isso eu chamo o fetichismo que adere aos produtos do trabalho, tão logo são produzidos como mercadorias, e que, por isso, é inseparável da produção de mercadorias."118

Em contraste com as questões suscitadas no capítulo anterior, Adorno e Horkheimer expressam um deslocamento no interesse pela sociologia weberiana com as publicações da $\mathbf{D E}$ e do Eclipse da razão. Durante a década de 1930, Horkheimer ocupou-se principalmente com as condições para o florescimento de uma racionalidade histórica substantiva a fim de realizar as promessas utópicas nascidas junto às sociedades modernas. A atuação incontrolada de forças socieconômicas desencadearia alto grau de imprevisibilidade na vida coletiva, tornando necessária a elaboração de mecanismos de controle sobre tais processos. Por assim dizer, a esperança seria lançar as bases teóricas de um domínio verdadeiramente racional sobre as sociedades e sobre os resultados das atividades humanas ${ }^{119}$. Os elementos progressistas inscritos na razão e na cultura seriam os antídotos contra a opressão econômica reproduzida por meio do funcionamento da moderna estrutura de autoridade. Comum às mais variadas instâncias das sociedades modernas, ela

118 Marx, K. \& Engels, F. O Capital; págs. 198-199.

119 Segundo Moishe Postone, em relação à maneira pela qual Horkheimer interpretava a moderna contradição entre teoria e prática na década de 1930 : "Horkheimer assenta essa contradição naquela entre as forças e as relações de produção. Com o seu arcabouço teórico, ele afirma que a produção humana coletiva constitui um todo social que, potencialmente, é organizável racionalmente. No entanto, a forma mediada pelo mercado de interconexão social e a dominação de classe baseada na propriedade privada dotam o todo social de um conjunto fragmentado e irracional. Assim, a sociedade capitalista é caracterizada pela necessidade cega e mecânica de desenvolvimento e pela utilização dos poderes humanos de controlar a natureza mais em favor de interesses particulares e conflitantes do que para um interesse geral. De acordo com a explicação de Horkheimer da trajetória do capitalismo, o sistema econômico baseado sobre a forma mercadoria fora caracterizado em seus primeiros estágios pela noção da congruência entre a felicidade individual e a social. (...). A sua dinâmica, contudo, tem originado desde então uma sociedade que já não mais promove o desenvolvimento humano, mas o reprime crescentemente e conduz a humanidade a uma nova barbárie. Com tal estrutura, a produção é socialmente totalizante, mas ela é alienada, fragmentada e presa de maneira progressiva pelo mercado e pela propriedade privada. As relações sociais capitalistas atravancam a realização daquela totalidade.” Postone, Moishe. Time, labor and social domination; págs. 106-107. 
foi interpretada como o fenômeno decisivo para compreender tanto as condições de manutenção da ordem coletiva quanto as possibilidades de transformação radical das relações sociais capitalistas.

Entretanto, a ascensão dos regimes nazifascistas parece impelir a uma alteração no diagnóstico de época desses frankfurtianos. Apostar nos aspectos progressistas da cultura moderna é insuficiente para construir uma sociedade emancipada. A própria razão ocidental não apenas convive com certos elementos regressivos, mas promove abertamente a barbárie por seus próprios métodos. Na verdade, ela não foi a única responsável pela catástrofe. Importantes questões econômicas, numerosas batalhas políticas e tantas outras disputas nas esferas culturais também contribuíram para tal desdobramento. De todo modo, a razão agiu ao lado daqueles que cometeram as maiores atrocidades e não quebraram a lógica da exploração econômica e das distinções de classe.

A humanização crescente da natureza, isto é, o paulatino processo de assenhoramento pelos homens da realidade circundante não conduziu à formação de uma sociedade qualitativamente superior $^{120}$. Antes, o contrário. Com o correr dos anos que antecederam e dos horrores que se consumaram com a segunda grande guerra europeia, os elementos regressivos tão peculiares ao capitalismo moderno tornaram-se cada vez mais evidentes e atuantes. Tais aspectos sombrios não são características pretensamente inatas aos indivíduos ou à vida coletiva, mas sim o retorno ao

120 Seria bastante interessante acompanhar com acurácia as discussões que levanto neste capítulo também em contraste com Marx. Infelizmente, não será possível me dedicar a essa questão com profundidade - na verdade, as referências serão apenas laterais. Contudo, convém indicar a leitura realizada por Alfred Schmidt que identifica no pensamento maduro de Marx uma perspectiva de crítica semelhante a essa formulada pelos frankfurtianos com DE. Segundo Schmidt: "Se o Marx dos Manuscritos parisienses, influenciado por Feuerbach e pelo romantismo, vê no trabalho um processo de humanização progressiva da natureza, uma humanização que coincide com a naturalização do homem e, portanto, considera que a histórica cunhada com o trabalho mostra-se, de forma cada vez mais clara, na equação naturalismo = humanismo, o Marx da análise econômica, muito mais crítico, se serve do termo Stoffwechsel [intercâmbio orgânico], de uma coloração científico-natural mas nem por isso menos especulativo, quando examina a mutável, embora não suprimível, luta do homem com a natureza. Este intercâmbio orgânico está vinculado com as leis naturais que precedem aos homens. Todo ato de dar forma a uma substância natural deve obedecer a legalidade peculiar da matéria. 'O homem só pode proceder como a natureza mesma em sua produção, quer dizer, só pode mudar as formas das substâncias. Ademais, o ato mesmo de dar forma não se produz sem se apoiar nas forças naturais, entre as quais Marx considera também os sujeitos ativos. Na medida em que os homens desatam as 'potências adormecidas' na matéria natural, 'liberam' esse material: ao transformar o morto em-si em um vivente para-nós, prolongam de certo modo a serie dos objetos produzidos pela história natureza e dão prosseguimento a ela em um estágio qualitativamente mais elevado. Mediante o trabalho humano a natureza leva adiante o seu processo de criação. O transtorno produzido pela práxis chega a adquirir, assim, uma significação não apenas social, mas também 'cósmica'.” El concepto de naturaleza em Marx; págs. 84-85 
natural desencadeado pela mediação social. O conceito apropriado para descrever essa situação não seria outro senão o de regressão. De forma literal, as sociedades modernas retrocederam inclusive em suas formas de sociabilidade mais elementares.

Uma barreira social e política erigiu-se contra o que seria o verdadeiro progresso ${ }^{121}$. Se a vitória de certas forças sociais significaria romper os limites da troca de equivalentes, elas deveriam ser vigorosamente derrotadas a fim impedir avanços reais. Com as instâncias de resistência da consciência individual debilitadas, a estrutura de dominação social porta-se como um automatismo progredindo conforme a crescente necessidade de repressão das pulsões humanas. Em DE:

O servo permanece subjugado no corpo e na alma, o senhor regride. Nenhuma dominação conseguiu ainda evitar pagar esse preço, e a aparência cíclica da história em seu progresso também se explica por semelhante enfraquecimento, que é o equivalente ao poderio. A humanidade, cujas habilidades e conhecimentos se diferenciam com a divisão do trabalho, é ao mesmo tempo forçada a regredir a estágios antropologicamente mais primitivos, pois a persistência da dominação determina, com a facilitação técnica da existência, a fixação do instinto através de uma repressão mais forte. A fantasia atrofia-se. A desgraça não está em que os indivíduos tenham se atrasado relativamente à sociedade ou à sua produção material. Quando o desenvolvimento da máquina já se converteu em desenvolvimento da maquinaria da dominação - de tal sorte que as tendências técnica e social, entrelaçadas desde sempre, convergem no apoderamento total dos homens - os atrasados não representam meramente a inverdade. Por outro lado, a adaptação ao poder do progresso envolve o progresso do poder, levando sempre de novo àquelas formações recessivas que mostram que não é o malogro do progresso, mas exatamente o progresso bem-sucedido que é culpado de seu próprio oposto. A maldição do progresso irrefreável é a irrefreável maldição. ${ }^{122}$

A superação desse enredo das coisas é também um desafio teórico. A fim de fundamentar um contraponto aos princípios hegemônicos da modernidade capitalista, Adorno e Horkheimer incumbiram-se da tarefa de subverter uma lógica milenar ${ }^{123}$. Uma crítica de tal magnitude exige não

121 Segundo Susan Buck-Morss: “Dialektik der Aufklärung foi uma tentativa de Adorno e Horkheimer em preencher precisamente a tarefa cognitiva que Benjamin havia identificado com a mais premente, isto é, desmantelar o mito da história como progresso. Para tanto eles se fundamentaram no trabalho do Instituto sobre a autoridade, e demonstraram que aquilo que Max Weber identificara como o crescimento da racionalização e 'desencantamento' da sociedade não levou progressivamente a uma ordem social racional, mas ao contrário, levou à novas estruturas de dominação nas formas do capitalismo monopolista e totalitarismo político.” Buck-Morss, Susan. The origen of negative dialects; p. 60-61.

122 Adorno, T. \& Horkheimer, M. Dialética do esclarecimento; p. 46.

123 Todavia, se a DE é um momento de inflexão no pensamento de Adorno e de Horkheimer, o seu saldo me parece muito mais complexo do que o traçado por certa tradição de comentadores da teoria crítica. Embora haja divergências pontuais em suas respectivas interpretações, autores como Habermas (principalmente nos capítulos “O entrelaçamento entre mito e esclarecimento: Horkheimer e Adorno" de seu Discurso filosófico da modernidade e “De Lukács a Adorno: racionalização como reificação” da Teoria do agir comunicativo), Axel Honneth (sobretudo em "Die geschichtsphilosophische Wende der Dialetik der Aufklärung: Eine Kritik der Naturbeherrschung” de Kritik der Macht), Albrecht Wellmer (em The persistence of modernity), Seyla Benhabib entre outros asseguram que a DE representaria não só uma ruptura com a produção da década anterior dos frankfurtianos como também o ponto de partida de um descolamento entre seus conceitos e categorias e a dinâmica interna da vida social. 
somente perscrutar a gênese da razão ocidental como também interpretá-la vis-à-vis às práticas sociais nela imbricadas.

Os padrões de racionalidade resultam de modos historicamente variáveis de interação dos homens com a natureza. Hipostasiada nas consciências e nas atividades dos indivíduos modernos, a razão em sua forma mais abstrata universalizou-se graças ao sistema de produção e de troca de mercadorias. Todavia, para forjar o seu tipo específico de conhecimento racional e para consolidar a sua nova maneira de lidar com a objetividade científica, o Ocidente percorreu um demorado trajeto iniciado com uma velha tendência atuante no universo mágico-religioso. Dos mais antigos rituais dos feiticeiros, passando pelas doutrinas religiosas e seus modos de relação com o divino até se chegar aos rigores dos procedimentos e dos métodos científicos, um longo processo de abstração despiu o princípio de dominação da natureza de qualquer resquício mágico-religioso.

No mundo moderno, essa razão constituída ao longo de séculos aparenta ser uma entidade laica. De acordo com os frankfurtianos, recobrar esse seu passado pré-histórico possibilitaria tanto compreender aspectos essenciais das formas modernas de sociabilidade quanto imaginar um outro destino para o Ocidente. Com o capitalismo tardio, essa razão revela o seu mais alto grau de irracionalidade - após abstrair todas as qualidades, ela contradiz de maneira direta qualquer expectativa de um futuro mais humano sobre a Terra. A crítica aos seus fundamentos mais elementares se mostra como um requisito necessário para superar os entraves produzidos por uma sociedade forjada nestes termos. Em DE:

O que seria diferente é igualado. Esse é o veredicto que estabelece criticamente os limites da experiência possível. O preço que se paga pela identidade de tudo com tudo é o fato de que nada, ao mesmo tempo, pode ser idêntico consigo mesmo. O esclarecimento corrói a injustiça da antiga desigualdade, o senhorio não mediatizado; perpetua-o, porém, ao mesmo tempo, pela mediação universal, na relação de cada ente com cada ente. Ele faz aquilo que Kirkegaard celebra em sua ética protestante e que se encontra no ciclo épico de Héracles como uma das imagens mais primordiais do poder mítico: ele elimina o incomensurável. Não apenas são as qualidades dissolvidas no pensamento, mas os homens são forçados à real conformidade. O preço dessa vantagem, que é a indiferença do mercado pela origem das pessoas que nele vêm trocar suas mercadorias, é pago por elas mesmas ao deixarem que suas possibilidades inatas sejam modeladas pela produção de mercadorias que se podem comprar no mercado. ${ }^{124}$

124 Adorno, T. \& Horkheimer, M. Dialética do esclarecimento; p. 27. 
Ao teorizar acerca de tal constelação de questões, um dos caminhos escolhidos pelos frankfurtianos parece levar ao pé da letra a sugestão original de Marx e de Engels. Ora, se foi necessário buscar um termo na nebulosa região do mundo religioso para nomear um fenômeno típico do capitalismo moderno, torna-se imprescindível passar por Weber. Suas análises comparativas das diferentes doutrinas e experiências religiosas ambicionavam investigar momentos-chave da formação da civilização ocidental. A seu modo, a sociologia da religião weberiana forneceria não somente instrumentos conceituais para analisar determinados fenômenos empíricos relacionados às ações mágico-religiosas, mas constituía-se também como uma espécie de sociologia da razão ${ }^{125}$.

A perspectiva dos frankfurtianos diverge de algumas de suas interpretações e subverte muitos de seus pressupostos. O diálogo com as categorias weberianas é mobilizado não apenas para explicitar como uma certa tendência hegemônica atuou na formação da moderna civilização europeia, mas principalmente a fim de questionar o seu sentido mais geral e julgar os seus próprios resultados. Em DE:

No sentido mais amplo do progresso do pensamento, o esclarecimento tem perseguido sempre o objetivo de livrar os homens do mundo e de investi-los na posição de senhores. Mas a terra totalmente esclarecida resplandece sob o signo de uma calamidade triunfal. O programa do esclarecimento era o desencantamento do mundo. Sua meta era dissolver os mitos e substituir a imaginação pelo saber. ${ }^{126}$

Acompanhar as torções às quais Adorno e Horkheimer submeteram o conceito weberiano de desencantamento do mundo traz também à tona dos desafios que esses frankfurtianos pretendiam

125 A importância desses temas para a DE me soa bastante similar ao que foi identificado por Flavio Pierucci no que concerne ao pensamento de Habermas. Ao comentar sobre a crescente tendência de valorização da sociologia da religião de Weber já nos anos 70, Pierucci afirma: “Com seu prestígio de grande filósofo alemão contemporâneo e, para completar, de pensador 'do bem', parece que Habermas transferiu um pouco de sua influência acadêmica para a tendência emergente entre os estudiosos de Weber de problematizar o estatuto universal da racionalização, mantendo sempre afiado o gume da crítica à ambiguidade ímpar do racionalismo ocidental enquanto 'racionalismo de domínio do mundo' [Weltbeherrschung] tal como o caracteriza Weber, designação que nos remete diretamente ao desencantamento esclarecido da natureza, com todas as contradições e irracionalidades que esse modo de relação com o mundo implica e acarreta.” Pierucci, Flavio. O desencantamento do mundo; págs. 22-23. Conquanto os alvos sejam praticamente os mesmos, os desdobramentos da abordagem realizada por Adorno e Horkheimer da sociologia de Weber se distinguem das questões surgidas, posteriormente, com Habermas. Infelizmente, devido sobretudo à complexidade dos autores envolvidos, não poderei me ater aos pormenores de tal comparação. De toda forma, Jessé Souza interpreta de modo muito elaborado o confronto de Habermas com o pensamento weberiano em seu Patologias da modernidade: um diálogo entre Habermas e Weber.

126 Adorno, T. \& Horkheimer, M. Dialética do esclarecimento; p. 19. 
enfrentar neste momento específico de suas produção intelectuais ${ }^{127}$.

\title{
Das portas do capitalismo moderno ao preanimismo.
}

\author{
“(...) o papel-moeda mais antigo servia para \\ pagamento não aos vivos, mas sim aos mortos”"128
}

Mesmo sem figurar entre as chamadas religiões mundiais, o interesse da sociologia weberiana pelo judaísmo é patente e explica-se não somente por sua inegável relevância como antecedente histórico do cristianismo e do islamismo, mas também - e talvez principalmente - pela própria intransigência de suas concepções teóricas. É certo que Weber não lhe creditava o grande papel de destaque no surgimento do moderno capitalismo europeu. Faltava-lhe ao menos um elemento decisivo: o ascetismo intramundano. Porém, e isto é determinante, o judaísmo antigo dera largada a uma noção cheia de consequências cujo ápice foi desfechado apenas com o calvinismo. Trata-se da eliminação da magia como recurso de veneração à divindade. Em A ética protestante:

Aquele grande processo histórico-religioso de desencantamento do mundo que teve início com as profecias do judaísmo antigo e, em conjunto com o pensamento científico helênico, repudiava como superstição e sacrilégio todos os meios mágicos de busca da salvação, encontrou aqui sua conclusão. ${ }^{129}$

Entre os puritanos, todo poder de barganha e a mera suspeita de que artifícios ao alcance dos homens pudessem condicionar desígnios divinos seriam, ao mesmo tempo, um pecado brutal e um disparate lógico. Os meios mágicos de comunhão com deus foram repelidos tanto nos dogmas teológicos quanto nas formas de conduta religiosa. Eles não seriam apenas as rotas mais turvas para requisitar benevolência divina, mas os próprios descaminhos que conduzem à perdição.

Com o calvinismo consolidou-se a ideia do dom da graça ser obra exclusiva da suprema sabedoria da única potência objetiva existente. A sua distribuição - desigual e definitiva - não tolera

127 Acerca do principal alvo da DE, Jay afirma: “Toda a tradição iluminista - o processo de desmitificação supostamente libertário que Max Weber havia chamado de die Entzauberung der Welt [o desencantamento do mundo] - era o verdadeiro alvo. Nesse ponto, eles seguiram Lukács em História e consciência de classe, onde a ideia weberiana de racionalização recebera uma crítica mais incisiva ao ser vinculada ao conceito de reificação. (...). Enquanto Weber enfrentava esse processo com estoica resignação, a Escola de Frankfurt ainda mantinha a esperança de uma interrupção no continuum da história.” Jay, Martin. A imaginação dialética; p. 324.

128 Weber, Max. "Sociologia da religião”; p. 282.

129 Weber, Max. A ética protestante; p. 96. 
reparo. Nada que venha da criatura pode suscitar alguma simpatia celeste. Os sacerdotes não têm autoridade de redimir os pecados ou de perdoar as ofensas. A salvação das almas não resulta do balanço positivo entre as tentações mundanas e o acúmulo de obras meritórias. Tampouco a regulamentação ascética da vida em seus pormenores altera o destino dos homens - ela é indício e nunca certeza de redenção. Sem expectativa de conquistar qualquer vantagem pessoal ou coletiva, a única recomendação válida aos fiéis seria dedicar suas existências integralmente à glorificação do nome de deus. Porque mesmo entre os eleitos não há ninguém digno de fazer a menor exigência aos céus. Em A ética protestante:

O puritanismo genuíno ia ao ponto de condenar até mesmo todo vestígio de cerimônia religiosas fúnebres e enterrava os seus sem canto nem música, só para não dar trela ao aparecimento da superstition, isto é, da confiança em eventos salvíficos à maneira mágico-sacramental. Não havia nenhum meio mágico, melhor dizendo, meio nenhum que proporcionasse a graça divina a quem Deus houvesse decidido negá-la. Em conjunto com a peremptória doutrina da incondicional distância de Deus e da falta de valor de tudo que não se passa de criatura, esse isolamento íntimo do ser humano explica a posição absolutamente negativa do puritanismo perante todos os elementos de ordem sensorial e sentimental na cultura e na religiosidade subjetiva - pelo fato de serem inúteis à salvação e fomentarem as ilusões do sentimento e a superstição divinizadora da criatura - e com isso fica explicada a recusa em princípio de toda cultura dos sentidos em geral. Isso por um lado. Por outro lado, ele constitui uma das raízes daquele individualismo desiludido e de coloração pessimista como o que ainda hoje repercute no “caráter nacional” e nas instituições dos povos com passado puritano - em flagrante contraste com as lentes tão outras pelas quais mais tarde a "Ilustração" veria os seres humanos. ${ }^{130}$

Antes de prosseguir é necessário um drástico recuo temporal. Em “Sociologia da religião (tipos de relações comunitárias religiosas)”, Weber chama atenção para o florescimento de uma forma de abstração que remonta às origens das ações mágico-religiosas. Muito embora traços preanimistas manifestem-se com vivacidade e indefinidamente por diversas sociedades, a representação da existência de seres - os espíritos - atuantes em um registro para além do naturalismo irrefletido já estaria na base das configurações mais embrionárias desse tipo de ação social. Se nem toda pedra serve como fetiche, se nem toda pessoa evoca fenômenos mágicos, o próprio ato de nomear a substância que distingue seres e objetos dotados de qualidades carismáticas exclusivas - o mana, o orenda, o maga ${ }^{131}$ - implica o reconhecimento de algo que não se restringe à imediata materialidade de relações factuais.

130 Idem. Ibidem; p. 96.

131 Idem. "Sociologia da religião”; p. 280. 
Inicialmente, o universo anímico concebia-se de maneira difusa e indeterminada. Essa realidade sui generis não consegue disfarçar completamente o seu íntimo parentesco com o mundo físico e natural. Entretanto, ainda que comporte níveis variáveis de indistinção pré-simbólica, o caráter extraordinário do carisma mágico-religioso pressupõe a existência de poderes de um tipo especial que intervêm tanto no destino dos indivíduos quanto no da vida em comunidade. Segundo Weber:

De todo modo, já se realizou assim, na maioria das vezes, uma abstração apenas aparentemente simples: a representação de certos seres que se ocultam "por trás" da atuação dos objetos naturais, artefatos, animais ou homens carismaticamente qualificados e que de alguma maneira determinam esta atuação - a crença nos espíritos. O "espírito", originalmente, nem é alma, nem demônio, nem sequer um deus, mas algo indefinido: material e mesmo assim invisível, impessoal, mas com uma espécie de vontade; é algo que confere ao ser concreto sua força de ação específica, que pode penetrar neste e, do mesmo modo, abandoná-lo - o instrumento que se torna inútil, o mago cujo carisma falha -, para desaparecer ou entrar noutra pessoa ou noutro objeto. ${ }^{132}$

Nesses estágios embrionários, as relações dos homens com tais seres não ultrapassam uma regulamentação precária e ocasional. O agregado de ensinamentos, este esboço de certa regras de conduta e de ordenamento dos rituais, ainda não fora reunido em torno de uma doutrina sistemática, e tampouco se desdobrou uma concepção de alma como unidade plenamente diferenciada da existência material de seus portadores. Vigora uma situação eminentemente caótica na qual não se tem exata clareza da natureza das almas e dos espíritos. Dentre inúmeras outras possibilidades, eles podem ser identificados com o que deixa de existir nos homens após a morte ou com o que os invade durante os sonhos, com algo que se manifeste em um êxtase orgiástico ou então - o que seria mais frequente - com uma substância não-homogênea composta de matéria e espírito. O mana é ora confundido com o corpo físico de objetos sagrados, ora imaginado como uma potência anímica existente dentro ou ao redor deles.

Esses seres sagrados ainda não são reconhecidos como se fossem algo pessoal ou duradouro e, raramente, recebem qualquer denominação particular. De acordo com Weber, o acento não recai propriamente na capacidade do mago em realizar coisas fantásticas ou mesmo na pessoalidade, 
impessoalidade ou supra pessoalidade das almas por ele mobilizadas ${ }^{133}$. Mas sobretudo na peculiaridade de certos rituais, de determinados eventos e processos encarnarem uma potência especial que os particulariza radicalmente. Tais objetos ou pessoas significam algo distinto do que se esperaria de uma existência meramente profana, pois são capazes de feitos únicos. Apelar para o auxílio dessas entidades - cuja força nem sempre é plenamente controlada, mas é sabidamente a única que possui influência sobre certos eventos - sedimentava-se como uma alternativa recorrente a fim de enfrentar um medo físico imediato que os homens compartilhariam até mesmo com os animais $^{134}$.

O pavor diante da presença de um cadáver torna-se contornável por intermédio de ritos de sepultamento, o receio de contato com os bens materiais deixados por um falecido pôde ser neutralizado pelos critérios que organizavam o luto de seus familiares. A mesma estratégia é válida ainda para provocar modificações meteorológicas, prever acontecimentos futuros, garantir o sucesso na caça, nas disputas com tribos hostis e apaziguar - ou atiçar - os humores de entidades poderosíssimas. Segundo Weber:

Uma vez surgido um reino das almas, demônios e deuses que levam uma existência extraterrestre, não palpável no sentido corrente, mas em regra apenas acessível mediante símbolos e significados - uma existência que, por conseguinte, sempre se apresenta como de sombras e, às vezes, como diretamente irreal -, isso repercute sobre o sentido da arte mágica. Se atrás das coisas e dos processos reais existe algo diferente, essencial, anímico, do qual os primeiros são apenas sintomas ou mesmo símbolos, deve-se então procurar influir não nesses sintomas ou símbolos, mas no poder que neles se manifesta, e isso por meios que falem a um espírito ou a uma alma, que, portanto, "signifique” algo: por outros símbolos. É então apenas uma questão da ênfase que os conhecedores profissionais desse simbolismo consigam dar a sua fé ou à elaboração mental desta, da posição de poder, portanto, que alcancem dentro da comunidade, dependendo da importância da magia, como tal, para o caráter peculiar da economia e da força da organização que sabem criar - e uma onda de ações simbólicas cobre o naturalismo primordial. Isso traz então consequências de grande alcance. $^{135}$

No mais das vezes sob a influência de entorpecentes e somente em situações extracoditianas, os leigos tomam contato com esse universo especial sempre sob a tutela de um especialista, o mago profissional. Ele é detentor de um saber secreto e eminentemente prático. Se ainda falta o nome da divindade à qual se devota oferendas e embora o número de seguidores e a constância pela qual 
seus serviços são solicitados sejam variáveis, acredita-se que as fórmulas mágicas proferidas, a infusão de certas substâncias, as máscaras e as vestimentas rituais possuam eficácia concreta. Na medida em que consigam entregar as encomendas prometidas sem atrasos ou surpresas, inicia-se uma intensa concorrência suscitando sentimentos de adoração religiosa ou de profanação em torno de objetos mais diversos, de certos fenômenos naturais ou de pessoas de diferentes origens. Segundo Weber:

Nas relações com os deuses e demônios, a situação não é outra. Além da eficácia efetiva ou imaginada que lhes é inerente, cada vez mais coisas e processos também atraem "significados”, e por meio de atos significativos procura-se obter efeitos reais. Já toda ação com efeito mágico provado, no sentido naturalista, é repetida rigorosamente na mesma forma. Isso estende-se agora a toda a área dos significados simbólicos. O menor desvio do provado pode torná-los ineficientes. Todos os círculos da atividade humana são atraídos para o círculo mágico simbolista. ${ }^{136}$

De plasticidade bastante restrita, o âmbito do sagrado erige-se como o universo da estereotipia. O abracadabra deve ser reproduzível consoante instruções precisas e previamente testadas. Ao menos durante os rituais, quem se arrisca a viver sob os auspícios de tais seres vê-se diante do desafio de respeitar interditos a certos comportamentos. Por um lado, o preço pago por não se observar um pormenor aparentemente insignificante no culto, pela indevida substituição de algum elemento durante a realização de um feitiço ou pela devotada adoração a um objeto apenas semelhante ao totem verdadeiro pode ser radical: o cantar desafinado nas danças rituais chega a causar a morte, as dúvidas sobre como fazer o sinal da cruz levou ao cisma da igreja russa no século $\mathrm{XVII}^{137}$, etc.

Por outro, tal conjunto de saberes e de práticas precisa demonstrar de forma reiterada a sua eficácia. Quando não a comprova, a figura do mago e os rituais que ele ministra são ridicularizados aos olhos de uma comunidade. Mesmo para o seu séquito mais fiel não há garantias prévias de que um feiticeiro possa indefinidamente suscitar a boa vontade de deuses e demônios, ou dominar o curso das coisas. A qualquer momento seu poder corre o risco de ser dissolvido, seu caldeirão e sua varinha de condão podem ser danificados e seu contato direto com o reino das divindades, 
interrompido. Segundo Weber:

A primeira e fundamental atuação do círculo de ideias "religiosas" sobre o modo de vida e a economia é, portanto, geralmente de natureza estereotipadora. Toda modificação de um costume que se realiza de algum modo sob o patrocínio de poderes supra-sensíveis pode afetar os interesses de espíritos e deuses. Assim, a religião multiplica inseguranças e inibições naturais em todo agente inovador: o sagrado é o especificamente invariável. ${ }^{138}$

Haveria, portanto, um acento pragmático bastante pronunciado para que todo esse arranjo continuasse de pé e fosse reverenciado. A ordem prática e cognitiva que toda ação mágica visa instaurar depende, direta e inequivocamente, da possibilidade de oferecer maior previsibilidade para os acontecimentos sujeitos à sua influência. Nas tentativas de superar o caos originário e garantir com maior segurança a satisfação de demandas variadas, mas quase sempre orientadas para este mundo - ou seja, para que se viva bem e muitos anos sobre a Terra ${ }^{139}$-, os objetos de devoção religiosa vinculados a processos sociais e naturais relativamente invariáveis e estáveis possuem uma inegável vantagem sobre todos os demais.

É certo que as explicações mágicas incrustadas no hábito de fazer cair chuva dos céus poderiam estar ancoradas em imputações causais objetivamente incorretas. O olhar que pretendesse apenas desmistificar a ingenuidade das especulações primitivas, no entanto, não enxerga um palmo à sua frente. Pouco importa se o mero acaso - desde que, por sorte, ele seja recorrente - garanta a eficácia de uma mímica. Pois, enquanto seus carismas especiais não sejam postos em dúvidas, todo fetiche e toda magia suscitam, no mínimo, a mesma confiança de uma ação racional. Não se atingiu ainda o estágio de abstração no qual a realidade é subsumida formalmente por meio dos conceitos científicos modernos. O pensamento mitológico, de acordo com Weber, organiza-se a partir de analogias e de parábolas. De toda forma, em ambos os casos a ação social é orientada pela obtenção de objetivos concretos, malgrado o fato de uma ser articulada em torno de um cálculo bem temperado de meios e fins, enquanto a outra se valer mais de regras da experiência ${ }^{140}$.

138 Idem. Ibidem; p. 283.

139 Idem. Ibidem; p. 279.

140 A esse respeito, Pierucci afirma: "No gesto de coagir os espíritos com uma fórmula mágica e não de lhes fazer um pedido, está embutida a certeza de obter deles uma intervenção que vá no sentido desejado pelo cliente e ordenado carismaticamente pelo feiticeiro. Embora possa parecer que o ato de magia, por não corresponder aos termos da lógica do nosso conhecimento, não seja exatamente o que costumamos chamar de racional, Weber aqui o classifica como uma ação subjetivamente racional com relação a fins, ou seja, subjetivamente racional também em sua 
Nesse sentido, caso o elo entre fórmulas mágicas e determinados acontecimentos se cubra de certezas, isto é, sempre que a reiteração de uma conduta típica desencadeie efeitos reais e reproduzíveis, o prestígio do mago ultrapassa fronteiras, o número de seus seguidores cresce exponencialmente e os espíritos sob sua ascendência tornam-se conhecidos por seus nomes próprios e por sua área de atuação. Segundo Weber:

Mesmo os “deuses” não são imaginados, desde o princípio, como seres “antropomórficos”. Assumem a forma de seres perenes a eles essencial apenas após a superação de concepções puramente naturalistas (...), em lugar das quais surgiu a idéia de que o deus perenemente idêntico a si mesmo, possua os diversos fogos, os dê e deles disponha ou se incorpora neles, a cada vez, de algum modo. Mas essa idéia abstrata só adquire consistência mediante uma ação dedicada invariavelmente ao mesmo deus, ou seja, por seu “culto", e por sua vinculação a uma associação contínua de pessoas, uma comunidade duradoura, para a qual o culto, como ação permanente tem este significado. (...). Uma vez assegurada a continuidade das figuras dos deuses, o pensamento daqueles que profissionalmente deles se ocupam pode dedicar-se ao ordenamento sistemático deste domínio de representação. ${ }^{141}$

Embora se trate de um processo historicamente dúbio e multifacetado, que vivencia toda sorte de reviravoltas e seja sujeito a contingências de vastas magnitudes, o inventário de rituais mágicos, as funções e os serviços prestados pelos magos e as demandas dos leigos tendem a se consolidar institucionalmente. Nada que tenha se passado seria necessário ou poderia ser encarado como a etapa prévia de um desenvolvimento lógico posterior. Os processos que conduziram das primeiras manifestações mágico-religiosas ao monoteísmo rigoroso foram vagarosos e absolutamente incertos. Ademais, inúmeras civilizações ficaram, de bom grado, no meio do caminho.

Porém, nas raríssimas ocasiões nas quais ele foi trilhado, a ratio desempenhou um papel sempre crescente ${ }^{142}$. Para responder às complexas súplicas originadas entre os leigos, a antiga figura

preocupação com os efeitos imediatos que o ritual mágico diz ter sobre as coisas e os eventos, os quais são percebidos unicamente em termos de uma mera faticidade.” Pierucci, Flávio. O desencantamento do mundo; p. 75.

141 Weber, Max. "Sociologia da religião”; p. 284.

142 De acordo com Weber, esse processo nunca se restringiu à esfera do pensamento. A sedução da ratio sempre andou entrelaçada à da formação de impérios sobre a Terra. O butim de guerras e batalhas não se resumia à pilhagem dos bens materiais, à escravização da força de trabalho estrangeira, à conquista de territórios estratégicos ou à busca por solos mais férteis. Ao seu lado, a tribo devastada terminou por ser forçada à reverenciar as divindades da nação mais poderosa. Mesmo que uma prévia disputa bélica não fosse sempre necessária ou indispensável e soluções diplomáticas tivessem sido comuns ao longo dos tempos, a representação intelectual da existência de seres universais e onipotentes só foi possível na medida em que os cultos às divindades locais perdessem sua graça. Segundo Weber: "O dominador do panteão ou um deus do panteão não é, de per si, um deus 'universal', internacional que domina o mundo. Mas, naturalmente, está sempre no caminho de vir a sê-lo. Todo pensamento 
do feiticeiro sofre concorrência da do sacerdote. Enquanto o primeiro balbuciava fórmulas mágicas sem ter exata clareza de estar evocando a própria coisa ou manuseando certos instrumentos conforme prescrições especiais, o segundo lida com uma constelação de abstrações muito mais consequentes. Quando pode ser nomeado, o deus monoteísta tem um único nome próprio e já não se confunde mais com qualquer objeto de existência física. Segundo Weber:

Os “deuses” representam, freqüentemente, e de modo algum apenas em sociedades pouco diferenciadas, um caos desordenado de criações acidentais casualmente mantidas pelo culto. Os próprios deuses védicos não constituem ainda um conjunto divino ordenado. Mas assim que, por um lado a reflexão sistemática sobre a prática religiosa e, por outro, a racionalização da vida em geral, com sua crescente especificação dos serviços esperados dos deuses, tenham alcançado certo nível, muito diverso em cada caso concreto, a regra é a “formação do panteão”, isto é, a especialização e caracterização fixas de determinadas figuras divinas, por um lado, e, por outro, a dotação delas com atributos fixos e alguma delimitação de suas respectivas “competências". ${ }^{143}$

Levado a cabo pelo exercício de um sacerdócio permanente, o lento trabalho de sistematização das doutrinas religiosas acompanhou, pari passu, todos os momentos de tal desdobramento. Primeiramente, houve uma diferenciação de competências e de funções. O deus da guerra, as divindades que afiançavam o sucesso na colheita e na caça, os espíritos responsáveis pela saúde e pela doença travam disputas nas quais os critérios do fracasso ou da vitória continuam a ser basicamente pragmáticos. Aquele que conseguiu suprir melhor e por mais tempo as súplicas dos fiéis é o mais poderoso e, portanto, o único que deve existir. Embora no mais das vezes tal conflito jamais encontre termo definitivo, os deuses que simbolizavam eventos mais abstratos e invariáveis conquistariam de forma mais fácil e duradoura a primazia do panteão. A adoração a todos os demais passou a ser vista com grande reserva e desconfiança. Na verdade, seu antigo prestígio tornou-se matéria para abominação e sinônimo de pecado. Segundo Weber:

Na formação da primazia, desempenham um papel importante fatores puramente

desenvolvido sobre os deuses exige, em grau crescente, que conste de modo unívoco a existência de um ser com a qualidade de deus, sendo o deus, portanto, 'universal' neste sentido. Também os filósofos dos helenos reencontravam, pela sua interpretação, as divindades de seu passavelmente ordenado panteão em todas as divindades existentes em outras partes. A tendência àquela universalização aumenta com a preponderância crescente do dominador do panteão, isto é, à medida que este assume traços 'monoteístas'. A formação do império chinês, a expansão da casta sacerdotal dos brâmanes a todas as formações políticas particulares em toda a Índia, o surgimento dos impérios persa e romano, todos estes processos favoreceram o nascimento do universalismo e do monoteísmo - de alguma forma, a ambos, mas nem sempre em grau igual -, ainda que com resultados muito diversos.” Idem. Ibidem; p. 291.

143 Idem. Ibidem; p. 284. 
racionais. Onde quer que se destaque uma rigidez muito grande em certas prescrições, de qualquer natureza - tratando-se muitas vezes de rituais religiosos estereotipados, repetidos com regularidade - e o pensamento religioso tome consciência dela, costumam ter a oportunidade da primazia aquelas divindades que mostram em seu comportamento o maior número de regularidades fixas, portanto, os deuses do céu e dos astros. (...). A ratio exige a primazia dos deuses universais, e toda formação conseqüente do panteão orienta-se, de alguma maneira, também por princípios sistemático-racionais porque sempre está exposta à influência seja de um racionalismo sacerdotal profissional, seja do esforço dos leigos para estabelecer uma ordem racional. E sobretudo a afinidade já mencionada entre a regularidade racional do curso dos astros, garantindo a ordem divina, e a inviolabilidade da ordem sagrada sobre a terra faz deles guardiães competentes dessas duas coisas das quais dependem por um lado a economia racional e, por outro, o domínio assegurado e ordenado das normas sagradas na comunidade social. ${ }^{144}$

Todas essas transformações, no limite, desencadeiam uma viva reverberação sobre as formas de veneração a esse deus único e supremo. De acordo com Weber, embora a transição seja absolutamente fluida e comporte inúmeras situações nas quais prevaleça uma espécie de contaminação entre os extremos, a coerção mágica sobre os espíritos e a súplica religiosa são distinguíveis conceitualmente nos termos de tipos ideias. Acreditar que a oração seja apenas um mecanismo utilizado para exigir contraprestações dos deuses é coisa muito distinta do fiel que reconhece a falibilidade inerente ao seu ser e, de maneira humilde, presta-se a custosas abnegações pessoais somente com o fito de elevar às alturas o nome daquele que lhe é absolutamente inatingível.

Se no primeiro caso as práticas comandadas pelos feiticeiros constrangem as divindades a agir conforme as aspirações humanas, no segundo a comunhão com o espírito altera até mesmo o sentido dos sacrifícios prestados em sua homenagem. Mesmo que imolações físicas de toda sorte componham o receituário de adoração a esse deus absoluto e transcendente, a devoção é ainda assim eminentemente espiritual - o cordeiro pode ser substituído pelo pão simbólico. Além disso, em vez de se requerer qualquer recompensa imediata, o máximo que se pede é por misericórdia.

\section{Segundo Weber:}

Um poder concebido, de algum modo, por analogia com o homem dotado de alma, pode ser forçado, assim como o "poder” naturalista de um espírito, a estar a serviço dos homens: quem possui o carisma de empregar os meios adequados para isto é mais forte do que mesmo um deus e pode impor a este sua vontade. Neste caso, a ação religiosa não é “serviço ao deus”, mas sim “coação sobre o deus”; a invocação não é uma oração mas uma fórmula mágica (...). Os componentes orgiásticos e mímicos do culto religioso, sobretudo o

144 Idem. Ibidem; p. 290. 
canto, a dança, o drama, além das típicas fórmulas fixas das orações, têm aqui sua origem não exclusiva mas fundamental. Ou a antropomorfização tende então a trasladar ao comportamento dos deuses a graça livre de um poderoso senhor mundano, a ser obtida mediante súplicas, presentes, serviços, tributos, adulações subornos e, por fim e nomeadamente, mediante um comportamento agradável que corresponde à vontade do senhor, concebendo os deuses, em analogia com este, como seres poderosos e inicialmente mais fortes apenas em termos quantitativos. Neste caso, surge a necessidade de um "serviço divino". ${ }^{145}$

Como se a alegria de deus andasse vestida de amarguras ${ }^{146}$, o Ocidente forjou o lugar e o tempo histórico no qual o processo de abstração presente desde as formas mais rudimentares da ação religiosa pôde atuar quase sem amarras ou baixo a limitações muito frouxas. O pressuposto necessário foi conceber o mundo como o lugar da perdição que não admite, sem a menor condescendência, espaço para satisfação de anseios humanos ligados ao apreço a valores e a prazeres intramundanos. Os santos autoconfiantes do protestantismo, ao suportar com virilidade o que Weber chamava do maior e mais intolerável controle eclesiástico sobre os indivíduos, forneceram o molde perfeito para uma sociedade que se porta como a filha dileta de séculos de renúncias e de privações. Eles não só produziram riqueza material em uma escala maior do que a admissível dentro de seus dogmas, mas construíram um ideal de caráter por meio do qual todo desvio da norma - sistemática e tida como sagrada - seria tanto abominável quanto incorrigível. Desbancando a proscrita mistura dos mana entre o corpo físico do fetiche e a alma que lhe dota de qualidades especiais, a crença na existência de deus como uma simples ideia e a forma típica de adoração a tal entidade ilustram uma das faces mais características do tipo de racionalidade que hoje conhecemos quase intuitivamente. Em A ética protestante:

A ascese lutou do lado da produção da riqueza privada contra a improbidade, da mesma forma que contra a avidez puramente impulsiva - condenando esta última com os nomes de covetousness \{cobiça\}, mamonismo, etc.: a ambição de riqueza com o fim último de ser rico. Pois enquanto tal, a posse de fato era uma tentação. Mas aí a ascese era a força “que sempre quer o bem e sempre faz o mal” - ou seja, o mal no sentido que ela tinha em mente: a posse e suas tentações. Pois, a exemplo do Antigo Testamento e em plena analogia da valorização ética das "boas obras”, ela via, sim, na ambição pela riqueza como fim o cúmulo da culpa, mas na obtenção da riqueza como fruto do trabalho em uma profissão, a benção de Deus. Eis porém algo ainda mais importante: a valorização religiosa do trabalho profissional mundano, sem descanso, continuado, sistemático, como meio ascético simplesmente supremo e a um só tempo comprovação o mais segura e visível da regeneração de um ser humano e da autenticidade de sua fé, tinha que ser, no fim das contas, a alavanca mais poderosa que se pode imaginar da expansão dessa concepção de

145 Idem. Ibidem; p. 292.

146 Rosa, Guimarães. Tutaméia; p. 46. 
vida que aqui temos chamado de “espírito” do capitalismo. ${ }^{147}$

Como é sabido, sobretudo quando se popularizou entre a massa dos crentes, a justificativa interna dessa peculiar conduta de vida religiosa não é nada óbvia ou evidente. De saída, ela contradiz um comportamento arraigado nos leigos. Ter à disposição um objeto concreto com poderes mágicos é muito mais atraente do que a veneração perdida no infinito. Se a predileção pela primeira é evidente, a pela segunda forma é inicialmente inexplicável. O uso de riquezas materiais, as relações com corpo, com a sexualidade e com as artes padecem de um controle jamais visto sobre a Terra, e o exigente sistema ético puritano não oferece nenhum benefício imediato para o cotidiano de seus fiéis. Pior, este deus absoluto, impiedoso e que vê blasfêmia em tudo não entra em contradições lógicas. Diluída pela radical ausência de meios mágicos para conquistá-la, a redenção religiosa é um objetivo bem pouco palpável, quando não praticamente inatingível - e cujo resultado só poderá ser descoberto no pós-túmulo. Segundo Weber:

Pois só com uma transformação radical do sentido de toda a vida, a cada hora e a cada ação, o efeito da graça podia se comprovar como um arranque do status naturae rumo ao status gratiae. A vida do "santo" estava exclusivamente voltada para um fim transcendente, a bem-aventurança, mas justamente por isso ela era racionalizada [de ponta a ponta] em seu percurso intramundano e dominada por um ponto de vista exclusivo: aumentar a glória de Deus na terra - jamais se levou tão a sério a sentença omnia in majorem Dei gloriam. E só uma vida regida pela reflexão constante podia ser considerada superação do status naturalis: foi com essa reinterpretação ética que os puritanos contemporâneos de Descartes adotaram o cogito ergum. Essa racionalização conferiu à piedade reformada seu traço especificamente ascético e consolidou tanto seu parentesco íntimo quanto seu antagonismo específico com o catolicismo. ${ }^{148}$

Mas - para esses homens - não há lugares sagrados no mundo, pois o único ser ímpio reside ainda antes dos céus. A humanidade não tem certeza de nada, porém somente aqueles que se mantiverem continuamente distantes das seduções mundanas e da carne podem sonhar algum dia em estarem próximos de deus. Quem suporta de maneira tão obstinada não desfrutar das conquistas de seu próprio trabalho adere com maior perseverança à única causa que vale a pena. Embora não ofereça nenhuma recompensa concreta ou desfrutável durante a vida, a vocação para a ascese intramundana demoveria certas sombras na cabeça dos indivíduos.

147 Weber, Max. A ética protestante; p. 156.

148 Idem. Ibidem; p. 107. 
A insegurança quanto à salvação de suas almas ainda persistirá. Contudo, se os primitivos apelavam a forças misteriosas a fim de minorar seus medos ante o futuro mais imediato, os seguidores de Calvino se utilizam de alguns outros artifícios para contornar o peso de seus temores. Nunca ninguém saberá a resposta final da mais candente das questões. No entanto, um caminho a ser trilhado evitaria que os homens conduzissem suas vidas atormentados pelo desespero. Quanto mais se mantivessem vigilantes em relação aos seus atos e aos seus desejos, tanto maior seria a convicção de estarem entre os eleitos. Porque o menor vacilo é sabidamente imperdoável, e quem sucumbe aos prazeres terrenos reconhece a inevitabilidade da própria condenação eterna. Em A

\section{ética protestante:}

Ora, se perguntarmos: em quais frutos o reformado \{o calvinista $\}$ é capaz de reconhecer sem sombra de dúvida a justa fé, a resposta será: numa condução da vida pelo cristão que sirva para o aumento da glória de Deus. E o que leva a isso é deduzido de sua divina vontade diretamente relevada na Bíblia ou indiretamente manifestada nas ordens do mundo criadas segundo fins (lex naturae). (...). E, portanto, por absolutamente incapazes que sejam as boas obras de servir como meio de obter a bem-aventurança eterna - já que o próprio eleito permanece criatura, e tudo o que ele faz permanece infinitamente aquém das exigências divinas -, não deixam de ser imprescindíveis como sinais da eleição. [Elas são o meio técnico, não de comprar a bem-aventurança mas sim: de perder o medo de não tê-la.] Nesse sentido, de vez em quando, elas são designadas diretamente como "indispensáveis à salvação”, ou a possessio salutis é vinculada a elas. Ora, em termos práticos isso significa que, no fim das contas, Deus ajuda a quem se ajuda, por conseguinte o calvinista, como de vez em quando também se diz, “cria” ele mesmo sua bem-aventurança eterna - em rigor o correto seria dizer: a certeza dela -, mas esse criar não pode consistir, como no catolicismo, num acumular progressivo de obras meritórias isoladas, mas sim numa auto-inspeção sistemática que a cada instante enfrenta a alternativa: eleito ou condenado? ${ }^{149}$

Posto isso, convém voltar os olhos à DE. Com atenção redobrada, Adorno e Horkheimer reexaminam todos esses momentos-chave previamente analisados por Weber. É intrigante notar que, no mesmo movimento, os frankfurtianos apropriam-se das linhas mestras da conceitualização weberiana, mas enxergam a necessidade de lhes conferir uma interpretação divergente, quando não radicalmente distinta. Essa monumental reconstrução histórico-conceitual da formação da civilização ocidental é investigada sob o prisma de uma verdadeira dialética. A agudização crescente do processo de abstração, cujo aparecimento data das mais remotas origens da vida social e conferiu peculiaridade a certas confissões religiosas ocidentais, é um elemento essencial do

149 Idem. Ibidem; págs. 104-105. 
projeto civilizatório do esclarecimento ${ }^{150}$.

Quando consciente de si, o progresso desta razão quis se estabelecer como um contínuo e inequívoco deslizar rumo ao reino de ordenamentos impessoais e de abstratas relações de equivalência - nas trocas mercantis, na justiça e nas demais formas de sociabilidade. Porém, destruir o animismo, o pensar por analogias e a antiga ambivalência e concretude dos mana requer um extremo de virulência que só se realiza aos solavancos. Não se trata de reescrever as etapas do milenar processo de racionalização já analisadas com grande argúcia e sofisticação pelo sociólogo de Heidelberg. Mais do que isso, é premente escutar por seu intermédio a voz de tudo aquilo que ficou para trás neste caminho e também do que fora vítima dele ${ }^{151}$. Em DE:

Toda tentativa de romper as imposições da natureza rompendo a natureza, resulta numa submissão ainda mais profunda às imposições da natureza. Tal foi o rumo tomado pela civilização européia. A abstração, que é o instrumento do esclarecimento, comporta-se com seus objetos do mesmo modo que o destino, cujo conceito é por ele eliminado, ou seja, ela se comporta como um processo de liquidação. Sob o domínio do nivelador abstrato, que transforma todas as coisas na natureza em algo de reproduzível, e da indústria, para a qual esse domínio do abstrato prepara o reproduzível, os próprios liberados acabaram por se transformar naquele “destacamento" que Hegel designou como o resultado do esclarecimento. $^{152}$

Porque, além de violento, o esclarecimento não cumpre ao que se propõe. O medo que o

primitivo sentiria ao supostamente se defrontar com a natureza mais crua é reposto em escalar

150 Em Teoria do agir comunicativo, Habermas destaca a mudança de escopo e de patamar da crítica frankfurtiana em DE. Diferentemente de Lukács, Adorno e Horkheimer fundamentariam a sua crítica à razão instrumental em coordenadas sócio-históricas bem anteriores ao surgimento do moderno capitalismo europeu. Enquanto o autor de História e consciência de classe havia conceitualizado a respeito do processo de reificação a partir da análise das relações de trabalho assalariado em moldes capitalistas, os frankfurtianos ampliariam a crítica até os fundamentos mais elementares da vida coletiva e da civilização ocidental. A dominação da natureza não tem origem em processos sociais capitalistas. Segundo Habermas: “(...) a abstração da troca é meramente a forma histórica, na qual o pensamento identificador desdobrou sua eficácia histórica universal e determina as formas de interação da sociedade capitalista. As eventuais referências às relações objetivas de troca serem derivadas de abstrações reais não nós podem fazer esconder que Adorno e Horkheimer de nenhuma maneira derivam a forma de pensamento a partir da forma mercadoria tal como feita por Lukács (e Sohn-Rethel). O pensamento identificador, cujo poder Adorno via operar já antes na Filosofia Primeira do que na ciência, assenta-se sobre raízes mais profundas do que as da racionalidade formal com a relação de troca; embora este apenas tenha ganhado o seu significado universal com a diferenciação dos meios de valor de troca.” Habermas, J. Teoria do agir comunicativo; págs. 506-507. A meu ver, o contraste de DE com a sociologia weberiana pode fornecer alguns elementos para uma interpretação do trabalho dos frankfurtianos em uma chave distinta. Antes de atingir a sua significação universal, o princípio de dominação da natureza atravessou um longo périplo mágico-religioso cujo sentido final foi conferido pelo crescente processo de abstração típico ao Ocidente. Todavia, ainda que essa abstração não tenha a sua gênese reportada às modernas relações capitalistas, a racionalidade que pressupõe uma concepção desencantada da natureza e não reconhece qualquer limite interno ou externo para o seu domínio somente conseguiu organizar plenamente a vida coletiva com a consolidação do capitalismo moderno.

151 Adorno, Theodor. “Idéias para a sociologia da música”; p. 262.

152 Adorno, T. \& Horkheimer, M. Dialética do esclarecimento; p. 27. 
maior pelo órgão que teria sido forjado a fim de eliminá-lo. Dado o modo pelo qual as coisas aconteceram, a abstração esclarecida rugiu como fera perante tudo o que lhe cheirasse a superstição, pouco importando se aquilo que fora sedimentado na estereotipia de um rito mágico fosse obscurantismo torpe, esboço de uma nova ordem social, parte de um sentido objetivo ou clamores e esperanças por redenção ${ }^{153}$.

Os nomes dos universais, consolidados justamente por simbolizarem processos invariáveis, prevaleceram e, de cabo a rabo, dirigiram-se contra os feiticeiros e contra tudo o que eles poderiam representar. Visto por aqueles, os seus recursos eram parcos e ineficientes. A magia visava talvez transformar o mundo em um jardim encantado, no qual os homens pudessem conviver com mais conforto e segurança. Os perigos continuariam sempre a lhes espreitar, embora o fizessem em escala abrandada. Para o esclarecimento isso é muito pouco. Era preciso que qualquer margem de insegurança fosse silenciada. A solução mais imediata seria reforçar irrefletidamente o poder daquilo que se repete. Compõe-se, assim, uma nova forma de vida e de submissão social. Em DE:

\begin{abstract}
A universalidade dos pensamentos, como a desenvolve a lógica discursiva, a dominação na esfera do conceito, eleva-se fundamentada na dominação do real. É a substituição da herança mágica, isto é, das antigas representações difusas, pela unidade conceptual que exprime a nova forma de vida, organizada com base no comando e determinada pelos homens livres. $\mathrm{O}$ eu, que aprendeu a ordem e a subordinação com a sujeição do mundo, não demorou a identificar a verdade em geral com o pensamento ordenador, e essa verdade não pode subsistir sem as rígidas diferenciações daquele pensamento ordenador. Juntamente com a magia mimética, ele tornou tabu o conhecimento que atinge efetivamente o objeto. Seu ódio volta-se contra a imagem do mundo pré-histórico superado e sua felicidade imaginária. Os deuses ctônicos dos habitantes primitivos são banidos para o inferno em que se converte a terra, sob a religião do sol e da luz de Indra e Zeus. ${ }^{154}$
\end{abstract}

Houve por percorrer um arriscado trajeto até que um mecanismo abstrato se enchesse de direitos para se transformar em arquétipo de toda espécie de experiências possíveis e, por certo ainda mais distante, a fim de que de maneira consciente o capitalismo tardio buscasse suprir as necessidades humanas com mercadorias produzidas em série e para as massas. Porém, a face de Janus do estratagema se manifestou com maior celeridade. Ganhando peso e corpo, a abstração apavora mais do que qualquer maldição atávica. Se o participante de uma antiga feitiçaria era 
vigiado exteriormente - tanto pelo mago quanto pelo conjunto do seu séquito -, os olhos da patrulha se multiplicaram e se internalizaram com a extinção dos mitos. A estereotipia não fora suprimida com a dessacralização dos fetiches. Na verdade, para Adorno e Horkheimer, ela expandiu-se de braços dados com a abstração - e é ela quem amedronta.

A pressão sofrida para se respeitar condutas típicas de um ritual mágico ultrapassou o caráter extraordinário do mesmo e esparramou-se feito grilhões sobre todas as esferas da vida social. O que comanda é o mais geral, abstrato e impessoal. Entre outras coisas, viver sob sua ascendência significa abandonar o amor pela peculiaridade de uma existência verdadeiramente individual e entregar-se a uma conduta de vida planejada com precisão matemática. Se os epígonos do puritanismo já não temem mais os castigos dos céus é porque antes eles acostumaram-se com a ideia de que suas vontades mais íntimas fossem moldadas pela internalização de um peculiar sistema ético. Submeter-se aos imperativos da produção racionalizada de bens a serem vendidos no mercado assumirá os ares de um simples passo lógico posterior. Em DE:

Os deuses não podem livrar os homens do medo, pois são as vozes petrificadas do medo que eles trazem como nome. Do medo o homem presume estar livre quando não há nada mais de desconhecido. É isso que determina o trajeto da desmitologização e do esclarecimento, que identifica o animado ao inanimado, assim como o mito identifica o inanimado ao animado. O esclarecimento é a radicalização da angústia mítica. A pura imanência do positivismo, seu derradeiro produto, nada mais é do que um tabu, por assim dizer, universal. Nada mais pode ficar de fora, porque a simples idéia do "fora” é a verdadeira fonte da angústia.... ${ }^{155}$

Tal como Weber, Adorno e Horkheimer reconhecem a atuação da abstração nas primeiras manifestações da magia. Porém, a questão já não é expor os movimentos iniciais desse processo que constituiu e se autonomizou com a civilização ocidental. Como foi dito, tampouco para Weber o radical descolamento de concepções teóricas formuladas por religiões monoteístas da concretude das práticas mágicas pode ser encarado como sinal de progresso ou de inevitabilidade lógica. Diante desse enlevo de fenômenos, os frankfurtianos dão a viva impressão de querer escancarar de maneira crítica alguns custos e implicações de tal encaminhamento ${ }^{156}$.

155 Idem. Ibidem; p. 29.

156 A esse respeito, Gabriel Cohn afirma: “O procedimento básico adotado, aqui e em outros lugares, foi anunciado em várias oportunidades por Adorno. Trata-se de conformar o objeto com o seu conceito, e cobrar dele a realização de tudo o que está contido neste. Isto permite, desde logo, assinalar os limites da efetivação do conceito na forma 
Homologamente à ciência, a magia representava sim uma tentativa de dominar a natureza.

No entanto, ela o pretendia por outros meios não somente mais modestos e precários, mas de uma qualidade em alguma medida distinta ${ }^{157}$. Está-se muito longe da situação na qual os sujeitos imaginam construir sua individualidade de forma autônoma em relação a qualquer objetividade. Durante um feitiço, o polo subjetivo não supõe ser uma unidade fechada e autossuficiente. Seu poder de coerção é proporcional à sua capacidade de se misturar ao sagrado, de se confundir com ele. É certo que nesse movimento, por certas vezes, o xamã também terminou por esconjurar o perigo com a imagem do perigo ${ }^{158}$, e com isso não haveria aparentemente nada de novo em nosso remotíssimo passado.

Conduto, ao mesmo tempo em que se negava a certeza e a consciência de si dos sujeitos, obtinha-se o reconhecimento da existência de um algo não manipulável a torto e a direito, malgrado

histórica que assume e na qual se apresenta como se estivesse realizado. O uso do termo Esclarecimento busca dar conta dessa relação complexa. Não se trata nem da razão sem mais nem a redução a uma classe particular, por mais dominante que seja. No mínimo trata-se de olhar a contrapelo, vendo a particularidade histórica na razão que se apresenta como universal sem mais, e vendo a possibilidade da razão plena na sua efetivação restrita ao âmbito de uma classe. Nesta perspectiva o termo não se limita a qualificar uma circunstância dada, ou um período histórico, nem muito menos o ponto alto de um progresso da razão. Designa o próprio processo de constituição e expansão da razão tal como a conhecemos (pelo menos para quem pensa a partir da Europa). E, nessa sua referência às luzes, a razão esclarecida é sujeita a uma crítica que busca acompanhar a sua trajetória mediante a demonstração, em cada passo, de que ela poderia ser diferente, e que se esforça por perceber as suas tendências internas e os seus limites.” Cohn, Gabriel. “Esclarecimento e ofuscação: Adorno \& Horkheimer hoje.”; p. 6.

157 De acordo com Honneth, com a adoção da perspectiva de uma teoria histórico-filosófica de dominação da natureza e, consequentemente, por rebaixar o fascismo a mero estágio histórico no inelutável processo de decadência da civilização, os frankfurtianos se mostrariam incapazes de compreender o modo da organização social das sociedades capitalistas no pós-guerra. A virada teórico-conceitual desencadeada com a publicação de DE se assentaria sobre um diagnóstico pessimista de época por meio do qual toda forma histórica de interação social seria um simples desdobramento lógico inexorável de um mecanismo abstrato de dominação da natureza. Segundo Honneth: "Considerações desse tipo trazem ao conhecimento o elemento implícito, sobre o qual repousa a construção histórico-filosófica da Dialética do esclarecimento. A sua base teórica constrói-se por uma teoria da dominação, que toma o controle instrumental sobre a natureza como ponto de saída. Na lógica identitária da razão instrumental, na subsunção do particular pelo universal, uma teoria como essa enxerga o modelo original de dominação do qual todas as outras formas de dominação são simples derivação. Com essa consequência, (...) a Dialética do esclarecimento aproxima-se de um tipo de tradição cultural pelo fato de que consideram a objetivação funcional da natureza pelos homens com a técnica e mesmo com a ciência como um índice de um processo de decadência civilizacional.” Honneth, Axel. Kritik der Macht; p. 54. A discussão com a sociologia weberiana, por outro lado, traz à tona a reflexão eminentemente sociológica travada por Adorno e Horkheimer na formulação do conceito de dominação da natureza. Embora a gênese histórico-social do modo pelo qual os homens modernos lidam com a natureza - tanto no interior dos laboratórios como na produção de mercadorias e em suas vidas interiores - seja reportada a um processo iniciado a milênios e, verdadeiramente, não reduzível à história do capitalismo moderno, o projeto dos frankfurtianos não era tanto identificar a atuação desse princípio abstrato desde os primórdios da civilização ocidental, mas - e, talvez, sobretudo - recobrar conceitualmente os elementos e os fenômenos socioculturais que, ao longo dos tempos e de diferentes maneiras, tanto lhe impuseram resistências como impeliram a seu desenvolvimento.

158 Adorno, T. \& Horkheimer, M. Dialética do esclarecimento; p. 30. 
o caráter particularmente interesseiro de tais práticas. Os rigores da estereotipia ritual também eram um limite à ação instrumentalizada. Ao menos de forma latente, a resistência do que fora concebido como o sagrado ele impediam os homens de ambicionarem ser os senhores de tudo, a qualquer tempo e maneira. Ainda que involuntariamente, a magia tem de conviver com algo que existe por ser diferente e exatamente por esta sua especificidade. A natureza não é mera presa a ser capturada, e também o sujeito - bastante distinto da moderna concepção de indivíduo - não se reduziu ao estigma de uma simples arapuca ou de artilharia pesada para caça. Em DE:

Como a ciência, a magia visa fins, mas ela os persegue pela mimese, não pelo distanciamento progressivo em relação ao objeto. Ela não se baseia de modo algum na “onipotência dos pensamentos”, que o primitivo se atribuiria, segundo se diz, assim como o neurótico. Não pode haver uma "superestimação dos processos psíquicos por oposição à realidade”, quando o pensamento e a realidade não estão radicalmente separados. A “confiança inabalável na possibilidade de dominar o mundo", que Freud anacronicamente atribui à magia, só vem a corresponder a uma dominação realista do mundo graças a uma ciência mais astuciosa que a magia. Para substituir as práticas localizadas do curandeiro pela técnica industrial universal foi preciso, primeiro, que os pensamentos se tornassem autônomos em face dos objetos, como ocorre no ego ajustado à realidade. ${ }^{159}$

As diferenças são tênues, mas essenciais para Adorno e Horkheimer. Não se trata de esperar das origens a solução para os enigmas do presente. Tampouco ela pode ser exemplo de futuro ${ }^{160}$. Entretanto, se com a magia ainda permaneciam distinções e, com isso, algum tipo de alteridade impunha resistência à projeção do subjetivo na natureza ${ }^{161}$, a época da fungibilidade universal pretende dar fim a tudo isso e define-se como o ápice do distanciar do pensamento em relação à coisa. Herdeira secular das transformações nascidas com as religiões ocidentais monoteístas, a

159 Ibidem, idem; p. 25.

160 Por ser lido a contrapelo, o longo processo de constituição da civilização ocidental revela, nesse sentido, momentos-chave nos quais a forma de interação dos homens com a natureza - ainda que visassem também dominá-la - conseguia, em determinadas circunstâncias e nunca de modo inequívoco, controlar os impulsos do agir instrumental. Porém, por se constituírem de modo irrefletido e, principalmente, por partilharem a mesma lógica de dominação social universalizada somente com o capitalismo moderno, tais resistências não são capazes de alterar o patamar civilizacional do Ocidente. A esse respeito, segundo Heinz Steinert: “(...), sustenta-se que formulações como a de que o esclarecimento - realizado - interverte-se novamente no mito foram derivadas por Horkheimer/Adorno a partir de mitos e de outras formas de pensamento racional não tão fria e automatizada, algo que a arte seria uma contra-imagem para os quais se deveria novamente retornar. Não dá para se negar que Horkheimer/Adorno oferecem elementos - e no todo a coisa é ainda mais clara - de que se trata de uma auto-reflexão do esclarecimento (Selbstaufklärung der Aufklärung) e não de quaisquer reorientações ou retornos. Que o próprio pensamento instrumental assumiu um caráter mitológico é uma formulação para a crítica dessa forma de pensamento - o mito não se torna nenhuma tipo melhor ou positivo de conhecimento em comparação com o pensamento instrumental autonomizado.” Steinert, Heinz. Das Verhängnis der Gesellschaft und das Glück der Erkenntnis; p. 36.

161 Adorno, T. \& Horkheimer, M. Dialética do esclarecimento; p. 22. 
ciência moderna não reconhecerá como legítimo nenhum tabu, a não ser o interdito que atinge o pensar e o agir baseados em uma racionalidade não meramente formal.

Ainda antes, convém analisar de maneira mais detida a apresentação do cortejo triunfante dessa razão realizado por Adorno e Horkheimer. Tal como narrado em DE, ele é de evidente inspiração weberiana. O pensamento mitológico foi a primeira grande tentativa de reunir elaborações teóricas, práticas ritualísticas e cognitivas da magia. Nesse estágio, as coisas já não se comportavam mais como anteriormente. Lascar o mármore no qual se esculpiu a figura de Zeus não diminuía em nada a sua magnanimidade. Entretanto, alguns traços preanimistas preservavam muito de seu poder e de seu significado. Certo de que são simples projeções humanas, o esclarecimento zomba de tais reminiscências e se fia com vigor crescente na crença da superioridade de uma realidade progressivamente menos substancial.

Como uma das vítimas preferenciais de tal influxo, a natureza vivenciou transformações profundas ao longo dos tempos. Ela foi progressivamente aplainada a fim de se tornar o substrato de uma dominação sem descanso. Armado de astúcias, o seu mais impiedoso predador não enxerga nela nenhum direito e não ouve sequer seus gemidos de horror. É certo que, em determinado sentido, a natureza ainda será uma realidade que nos apavora. Seja no mundo físico, seja na vida interna dos indivíduos o menor sinal de sua manifestação desencadeia uma reação quase automática. Dominação e mais dominação são eleitas as palavras de ordem para os mais diversos momentos. Que tal entendimento desfigure os homens e todas as formas de existência não diminuirá em nada o seu prestigio. Mais radical e pior, essa postura converte-se em sinônimo daquilo que seria o verdadeiramente racional. Em DE:

O mito converte-se em esclarecimento, e a natureza em mera objetividade. O preço que os homens pagam pelo aumento de seu poder é a alienação daquilo sobre o que exercem o poder. $\mathrm{O}$ esclarecimento comporta-se com as coisas como o ditador se comporta com os homens. Este conhece-os na medida em que pode manipulá-los. O homem de ciência conhece as coisas na medida em que pode fazê-las. É assim que seu em-si torna para ele. Nessa metamorfose, a essência das coisas revela-se como sempre a mesma, como substrato da dominação. Essa identidade constitui a unidade da natureza. Assim com a unidade do sujeito, ela tampouco constitui um pressuposto da conjuração mágica. Os ritos do xamã dirigiam-se ao vento, à chuva, à serpente lá fora ou ao demônio dentro do doente, não a matérias ou exemplares. Não era um e o mesmo espírito que se dedicava à magia; ele 
mudava igual às máscaras do culto, que deviam se assemelhar aos múltiplos espíritos. (...). É só enquanto tal imagem e semelhança que o homem alcança a identidade do eu que não pode se perder na identificação com o outro, mas torna definitivamente posse de si como máscara impenetrável. É à identidade do espírito e a seu correlato, à unidade da natureza, que sucumbem as múltiplas qualidades. A natureza desqualificada torna-se matéria para uma simples classificação, e o eu todo-poderoso torna-se o mero ter, a identidade abstrata. ${ }^{162}$

Se essa é a tendência atuante desde tempos imemoriais e que se arrastará até o capitalismo tardio, é essencial não se furtar em revelar a ambivalência de todo esse processo civilizatório bem como seus reiterados equívocos e suas potencialidades malbaratadas. O que prevaleceu tem a força arrebatadora de um rolo compressor. Nem por isso, de acordo com os frankfurtianos, ele conseguiu abafar completamente a manifestação daquilo que não seja resultado de sua pura imanência. As tentativas de espiritualização definitiva dos mana nem sempre foram bem sucedidas, e o conceito científico moderno tampouco conseguirá subsumir plenamente a realidade. Embora no mais das vezes ignorada, a experiência de uma coisa ser ela mesma e, ao mesmo tempo, algo distinto de si oferece-se a quem quiser ouvir. O prenúncio do pensamento dialético acompanha a vida social desde suas primeiras formas de organização. Mesmo quando o positivismo proclama ser a magistratura da razão, o esclarecimento é também aquilo que permite pensar para além de seus limites internos - é tanto o progresso da dominação como a possibilidade de seu desnudamento ${ }^{163}$.

\section{Em DE:}

Quando uma árvore é considerada não mais simplesmente como árvore, mas como testemunho de uma outra coisa, como sede do mana, a linguagem exprime a contradição de que uma coisa seria ao mesmo tempo ela mesma e outra coisa diferente dela, idêntica e não-idêntica. Através da divindade, a linguagem passa à tautologia da linguagem. $\mathrm{O}$ conceito, que se costuma definir como a unidade característica do que está nele subsumido, já era desde o início o produto do pensamento dialético, no qual cada coisa só é o que ela é tornando-se aquilo que ela não é. Eis aí a forma primitiva da determinação objetivadora na qual se separam o conceito e a coisa, determinação essa que já está amplamente desenvolvida na epopéia homérica e que se acelera na ciência positiva moderna. ${ }^{164}$

Porém, o esclarecimento constituiu-se como um logro, que se pretende astucioso. Ante a insofismável fragilidade dos homens em relação à natureza, ele assegura que o principal perigo reside no abismo do desconhecimento. No minuto derradeiro a magia haveria de falhar e,

162 Idem. Ibidem; p. 24.

163 Idem. Ibidem; p. 50.

164 Idem. Ibidem; p. 29. 
sorrateiramente, o mecanismo calculador demonstraria uma sabedoria superior. Weber escapou dessa armadilha - era de domínio sobre os homens e sobre as coisas que também ele estava falando. Pouco importou que outros povos tivessem um ouvido musical mais sensível do que o nosso, que a medicina na Índia desenvolvesse saberes refinadíssimos de caráter empírico, ou ainda que o homem moderno conheça incomparativamente menos a respeito das leis da física nas quais ele confia cegamente ou das condições técnicas que permitem colocar um trem em marcha do que o selvagem acerca dos princípios mágicos que regulam todo o universo ou os seus afazeres cotidianos ${ }^{165}$.

Pois, embora cioso de suas elucubrações teóricas, o esclarecimento é pouco afeito ao convencimento por argumentos assim tão razoáveis. De acordo com os frankfurtianos, a potência racional inscrita nos mana soçobra, pois ainda cego e temeroso, ele se reduz à uma simples duplicação da natureza, à uma tautologia do terror ${ }^{166}$. Em vez de apostar na ambiguidade do novo e nas incertezas de um destino aberto, ele refugia-se na monotonia da velha repetição do invariável tanto para lidar com os problemas do mundo físico como com os da vida coletiva. Apavorados ante tantas outras possibilidades, os homens submeteram-se às normas testadas e consolidadas socialmente. O caminho escolhido pavimentou-se pela eliminação do incomensurável ${ }^{167}$.

Paulatinamente, a concretude dos fetiches foi volatizada e as representações mágico-religiosas difusas encontraram abrigo em torno de doutrinas mais sistemáticas e coerentes. Ainda que tardasse muito, os princípios mais gerais e abstratos mostrariam ser os mais regulares, inteligíveis e previsíveis. O flerte estendeu-se por séculos, e a abstração conseguiu vender-se como a parceira ideal para todo intercâmbio humano. Finalmente, o mais essencial torna-se o desencarnado, aquilo que prescinde de matéria. Porém, no lugar de uma boa nova, apenas se expressa uma transformação e uma intensificação das relações de mando e de coerção social. Em

\section{DE:}

No mundo luminoso da religião grega perdura a obscura indivisão do princípio religioso venerado sob o nome do "mana" nos mais antigos estágios que se conhecem da

165 Idem. “Ciência como vocação”; p. 30.

166 Adorno, T. \& Horkheimer, M. Dialética do esclarecimento; p. 29.

167 Idem. Ibidem; p. 27. 
humanidade. Primário, indiferenciado, ele é tudo o que é desconhecido, estranho: aquilo que transcende o âmbito da experiência, aquilo que nas coisas é mais do que a sua realidade já conhecida. O que o primitivo aí sente como algo de sobrenatural não é nenhuma substância espiritual oposta à substância material, mas o emaranhado da natureza em face do elemento individual. O grito de terror com que é vivido o insólito torna-se seu nome. Ele fixa a transcendência do desconhecido em face do conhecido e, assim, o horror como sacralidade. A duplicação da natureza como aparência e essência, ação e força, que torna possível tanto o mito quanto a ciência, provém do medo do homem, cuja expressão se converte na explicação. Não é alma que é transposta para a natureza, como o psicologismo faz crer. O mana, o espírito que move, não é nenhuma projeção, mas o eco da real supremacia da natureza nas almas fracas dos selvagens. A separação do animado e do inanimado, a ocupação de lugares determinados por demônios e divindades, tem origem nesse pré-animismo. ${ }^{168}$

Isso porque o pressuposto da abstração é a separação do sujeito em relação ao objeto. Tal operação, no entanto, não surge de crendices pagãs, de compêndios teológicos ou da atividade nos laboratórios. Para os frankfurtianos, ela funda-se na distância em relação à coisa que o senhor conquista mediante os dominados ${ }^{169}$. A sociedade na qual o princípio de equivalência governa todas as formas sociabilidade diferencia-se das do passado na medida em que a coerção social não é assim tão direta e evidente. Tanto em uma como nas outras, a coletividade surge e preserva sua existência pela imposição da divisão do trabalho. A separação das tarefas e das funções sociais são historicamente variáveis. Porém, a distinção entre dominantes e dominados permaneceu sempre intocável. Os indivíduos defrontam-se com o todo social e experimentam o seu objetivo mais persistente - a consolidação do poder de mando dos privilegiados.

Cada qual a seu modo, as instituições políticas e administrativas, as práticas sociais, as esferas culturais e intelectuais encarnam uma racionalidade que é a condição de autoconservação de toda ordem social existente. O que diverge da norma, seja ela forjada pela tradição ou por princípios abstratos, ofende à coletividade. A ativação desta razão imanente converte-se na execução do particular ${ }^{170}$. Quando ela se corporificava preferencialmente em símbolos religiosos, as potências terrenas incumbiam-se de garantir a harmonia com os céus independentemente de quanto isso significasse em termos de violência e de opressão diretas. Caso o eu seja formado à imagem e à semelhança do poder invisível da abstração, o ideal a ser seguido inscreve-se sobretudo na 
consciência dos indivíduos. Todavia, se essa repressão interna não se mostra suficiente ou desgasta-se com o tempo, a unidade entre a coletividade e a dominação faz valer antigas estratégias para garantir que o todo permaneça inalterado como sempre. Em DE:

O mana não-idêntico e difuso é tornado consistente pelos homens e materializado à força. Logo os feiticeiros povoam todo lugar de emanações e correlacionam a multiplicidade dos ritos sagrados à dos domínios sagrados. Eles expandem o mundo dos espíritos e suas particularidades e, com ele, seu saber corporativo e seu poder. Nas primeiras fases do nomadismo, os membros da tribo têm ainda uma parte autônoma nas ações destinadas a influenciar o curso da natureza. Os homens rastreiam a caça, as mulheres cuidam do trabalho que pode ser feito sem um comando rígido. Quanta violência não foi necessária antes que as pessoas se acostumassem a uma coordenação tão simples como essa é impossível determinar. Nela, o mundo já está divido numa esfera do poder e numa esfera profana. Nela, o curso da natureza enquanto eflúvio do mana já está erigido em norma, que exige a submissão. Mas, se o selvagem nômade, apesar de toda a submissão ainda participava da magia que a limitava e se disfarçava no animal caçado para surpreendê-lo, em períodos posteriores o comércio com os espíritos e a submissão foram divididos pelas diferentes classes da humanidade: o poder está de um lado, a obediência de outro. Os processos naturais recorrentes e eternamente iguais são inculcados com ritmo do trabalho nos homens submetidos, seja por tribos estrangeiras, seja pelas próprias cliques de governantes, no compasso da maça e do porrete que ecoa em todo tambor bárbaro, em todo ritual monótono. Os símbolos assumem a expressão do fetiche. ${ }^{171}$

De acordo com Adorno e Horkheimer, é nesse momento que a linguagem adentra na história. Por seu intermédio prenunciar-se-á o ignóbil elogio à disciplina que apenas muito tardiamente a grande filosofia burguesa conseguiu elaborar de forma esclarecida. Com os sacerdotes, a linguagem não era ainda composta pelas fichas neutras, às quais a ciência moderna reservaria a maior das estimas. Já não era também da espécie indistinguível dos mana, embora fosse não só palavra, mas também imagem.

Em tempos mitológicos, os seres ou os eventos representados como eternos voltavam a existir mediante as suas confirmações ritualísticas, respeitando estritamente determinadas prescrições simbólicas. Sacralizava-se a ordem social, e as suas cerimônias abençoavam o comando político-econômico das comunidades antigas. Porém, a natureza era influenciada pela assimilação e não dominada pelo trabalho. Os conceitos universais não detinham toda a soberba que conquistariam posteriormente. As leis particulares ainda se prestavam à ordenar as relações com as divindades, e a comunicação com os deuses adequava-se aos limites de um círculo mágico. Ao se metamorfosear em um demônio para assustá-lo ou suavizá-lo, o feiticeiro relembrava certa $\overline{171 \text { Idem. Ibidem; págs. 33-34. }}$ 
independência selvagem vivenciada durante o nomadismo. Ele não se reduzia a uma identidade abstrata, e era a própria natureza quem personificava o poder universal ${ }^{172}$.

A primeira torção da linguagem adveio após o ataque inicial do esclarecimento. Os mitos já eram produtos dele, embora se expressassem com a fantasia correndo à solta. Isso soava como um arcaísmo intolerável. Mais distantes das coisas, os conceitos universais impuseram-se aspirando galhardia. Na realidade, eles também camuflavam as estratégias mais rebuscadas de dominação social. Com a pretensão própria aos espíritos esclarecidos, eles aprofundaram o rompimento entre a palavra, a coisa e o seu significado e, ao mesmo tempo, entre os dominantes e os dominados. Passados muitos e muitos séculos, o positivismo radicalizou esse enfadonho ensinamento. A língua hegemônica das universidades e dos laboratórios prescinde conscientemente da poesia e da expressividade. Classificar os fatos imediatos da percepção parece não requerer grande grau de imaginação. Segundo suas crendices, não há mais nada de novo sob o sol, e o maior sinal de sabedoria é conformar-se com o mundo tal como ele se apresenta. Que essa sabedoria seja insossa, é algo um tanto evidente. Mas que ela perpetue relações de dominação por meio de mecanismos supostamente tão neutros e abstratos é algo bem mais complexo. Em DE:

\begin{abstract}
A unidade de coletividade e dominação mostra-se antes de tudo na universalidade que o mau conteúdo necessariamente assume na linguagem, tanto metafísica quanto científica. A apologia metafísica deixar entrever a injustiça da ordem existente pelo menos através a incongruência do conceito e da realidade. Na imparcialidade da linguagem científica, o impotente perdeu inteiramente a força para se exprimir, e só o existente encontra aí seu signo neutro. Tal neutralidade é mais metafísica do que a metafísica. ${ }^{173}$
\end{abstract}

Por mediações cada vez mais elaboradas, a violência de igualar o que seria diferente eludiu-se ao longo dos tempos. O princípio e as estratégias de dominação contidos na abstração penetram e se naturalizam nos indivíduos. De acordo com os frankfurtianos, somente a reconstrução da gênese da razão ocidental revela o que foi escondido na interioridade dos homens modernos, isto é, aquilo que os torna suscetíveis a aceitar como válidos determinados tipos de conduta. A linguagem e os códigos culturais mais gerais estruturam a vida social. O pensamento não apenas

172 Idem. Ibidem; p. 31. 173 Idem. Ibidem; p. 35. 
espelha passivamente a dinâmica das relações materiais das sociedades, mas constitui ele também a própria realidade social. Sendo igualmente o seu resultado e o seu pressuposto, ele articula e dá expressão a formas de sociabilidade tidas como ideais. São forjados padrões de coordenação da produção e da distribuição de riqueza social, elabora-se interditos morais, chancela-se gostos estéticos e formula-se regras para as atividades práticas e intelectuais, etc..

Mas ainda resta uma questão anterior. É o tipo hegemônico de racionalidade, invadindo as mais profundas instâncias psíquicas, que molda a vida anímica e a relação dos homens com seus os corpos e com os outros objetos. Antes mesmo da ação ser consciente, os indivíduos são condicionados a aceitar determinadas escolhas de experiência e de sensibilidade, incentiva-se o aparecimento de certas estruturas cognitivas, de formas de percepção e de julgamento. No que pese seu aspecto etéreo, tais elementos possuem inegável origem em processos sociais ${ }^{174}$. Paralelamente, eles interferem de forma direta e efetiva sobre a vida das sociedades. Em DE:

É a unidade de coletividade e dominação e não a universalidade social imediata, a solidariedade, que se sedimenta nas formas de pensamento. Os conceitos filosóficos nos quais Platão e Aristóteles expõem o mundo, exigiram, com sua pretensão de validade universal, as relações por eles fundamentadas como a verdadeira e efetiva realidade. Esses conceitos provêm, como diz Vico, da praça do mercado de Atenas. Eles refletiam com a mesma pureza das leis da física a igualdade dos cidadãos plenos e a inferioridade das mulheres, crianças e dos escravos. A própria linguagem conferia ao que era dito, isto é, às relações de dominação, aquela universalidade que ela tinha assumido como veículo de uma sociedade civil. A ênfase metafísica, a sanção através de idéias e normas, nada mais era senão a hipostasiação da dureza e da exclusividade que os conceitos tinham que assumir onde quer que a linguagem reunisse a comunidade dos dominantes para o exercício do comando. ${ }^{175}$

Antes da razão se definir como ciência positiva, a atividade humana como um agir

174 Em Sobre a gênese materialista da razão cognitiva em Dialética do esclarecimento, Carlos Henrique Pissardo apresenta uma discussão interessante e muito bem fundamentada a respeito da interpretação frankfurtiana das origens sociais da razão ocidental. De acordo com Pissardo, seja no diálogo com uma certa tradição sociológica-marterialista (além Lukács e Sohn-Rethel, o autor ainda destaca as discussões dos frankfurtianos com a sociologia de Émile Durkheim) ou com a psicanálise freudiana, os frankfurtianos nunca deixaram de apontar as relações de tipos específicos de racionalidade - e, de maneira mais concreta, no que tange à razão instrumental com determinadas formas de atividade prática, ainda que tais processos não fossem sempre circunscritos ao aparecimento do mundo moderno. Segundo Pissardo: "Perscrutar uma gênese materialista da razão cognitiva na Dialética do Esclarecimento significa, antes de tudo, buscar os processos sociais e psíquicos que acompanharam esse empobrecimento da razão no mundo ocidental moderno; empobrecimento esse que reduz a razão a um mero instrumento de cálculo sobre a adequação eficaz entre meios e fins e que naturaliza essa redução como uma qualidade inata do aparelho psíquico humano. Apenas uma genealogia materialista desse processo permite-nos compreender o que há de crítica social (e civilizacional) nesse questionamento da razão que, à primeira vista, pode parecer como tão somente uma discussão regionalizada ao âmbito da filosofia epistemológica.” Pissardo, Carlos H. Sobre a gênese materialista da razão cognitiva em Dialética do esclarecimento; p. 102.

175 Adorno, T. \& Horkheimer, M. Dialética do esclarecimento; p. 35. 
meramente instrumental e a natureza como substância a ser manipulada, também para os frankfurtianos a reforma protestante foi decisiva para a história de nossa civilização. De um lado, ela preparou a campa dos conceitos universais. De outro, os seus dogmas serviram-se dos favores daqueles para se generalizar.

A oração ao deus uno e absoluto não possui significado transcendente e peremptoriamente todos os instrumentos mágicos foram banidos. Os puritanos respeitavam estritamente a palavra de deus justamente por sua radical incompreensibilidade. Ainda que ao desvirtuá-la os homens soubessem estar condenados ao pior dos infernos, a vida dos eleitos talvez não fosse assim tão gloriosa ou menos terrível. As esperanças de redenção se evaporaram com a coerência de Calvino.

Se Weber observou as consequências da ética protestante na vida prática de quem se imaginava entre os escolhidos - e que fariam de tudo para não perder tamanha honraria -, a questão para os frankfurtianos parece ter se voltado mais para a repercussão dessa doutrina na interioridade de todos os desafortunados, estando entre os eleitos ou não, sendo eles pecadores ou não. Para a sorte daqueles a quem o sorriso desbotado do destino expressa antes sadismo do que encorajamento. De nada bastaria rebaixar a vida inteira aos rígidos compromissos ascéticos caso o fiel não estivesse previamente entre os eleitos. Além de brutal, incentivar a crença na salvação das almas sob tais condições desencadearia um estilo de vida bastante pernicioso. Em DE:

É através da fé que a religiosidade militante dos novos tempos - Torquemada, Lutero, Maomé - pretendia reconciliar o espírito e a vida. Mas a fé é um conceito privativo: ela se anula com fé se não ressalta continuamente sua oposição ao saber ou sua concordância com ele. Permanecendo dependente da limitação do saber, ela própria fica limitada. A tentativa da fé, empreendida no protestantismo, de encontrar, como outrora, o princípio da verdade que a transcende, e sem a qual não pode existir diretamente na própria palavra e de restituir a esta a força simbólica - essa tentativa teve como preço a obediência à palavra, aliás a uma palavra que não era nada sagrada. (...). Na secreta consciência da deficiência que lhe é necessariamente inerente, da contradição imanente nela e que consiste em fazer da reconciliação sua vocação, está a razão por que toda a honestidade dos fiéis sempre foi irascível e perigosa. Não foi como exagero mas como realização do próprio princípio da fé que se cometeram os horrores do fogo e da espada, da contra-reforma e da reforma. A fé não cessa de mostrar que é do mesmo jaez que a história universal, sobre a qual gostaria de imperar; nos tempos modernos, ela até mesmo se converte em seu instrumento preferido, em sua astúcia particular. ${ }^{176}$

Assim, o sangue que jorrou das espadas dos cruzados, os genocídios perpetrados com a

176 Idem. Ibidem; p. 32-33. 
cristianização de povos e de civilizações e o fanatismo dos que infligiram os maiores sacrifícios a si e a outrem não foram os últimos atos da escalada de horrores tão próxima às doutrinas religiosas. Sem espaço para um desafogo, os desencantados dogmas puritanos acrescentaram algo. Na medida em que se preservavam das inconveniências de tentações peculiares a cada esfera da vida coletiva, a férrea conservação das atividades sociais tornou-se o único consolo ante a incerteza mais absoluta. Elas existem pois são criações divinas, são provações suportáveis somente aos ungidos pela graça. Não se adaptar plenamente a elas é o mesmo que cometer uma heresia irremediável, porque após o pecado não há volta possível à casa do pai.

A velha estereotipia ritual volta à cena renovada. Quando a conduta de vida ascética perdeu esse tipo tão especial de sanção divina, uma ética de vida secular continuou com os mesmos poderes e com a mesma intransigência. Os homens aferram-se aos seus inglórios papeis sociais e identificam-se com seus carrascos. A adaptação ao ideal de sujeito e a autoconservação das formas sociais abarcaram um sentido mais comezinho. Não são as portas dos céus que se fecharam a quem se desgarra do sancionado socialmente. Por mais que o sucesso econômico dependa de tantos outros fatores, não trabalhar de sol a sol ameaça conduzir rumo ao descalabro financeiro. Também aqui não há descanso possível e transcender essa barreira à experiência é algo que se deve evitar diuturnamente. Em DE:

Segundo o juízo do esclarecimento, bem como o do protestantismo, quem se abandona imediatamente à vida sem relação racional com a autoconservação regride à pré-história. O instinto enquanto tal seria tão mítico quanto a superstição; servir a Deus não postulado pelo eu, tão insano quanto o alcoolismo. O progresso reservou a mesma sorte tanto para a adoração quanto para a queda no ser natural imediato: ele amaldiçoou do mesmo modo aquele que, esquecido de si, se abandona tanto ao pensamento quanto ao prazer. Mas quanto mais o processo da autoconservação é assegurado pela divisão burguesa do trabalho, tanto mais ele força a auto-alienação dos indivíduos, que têm que se formar no corpo e na alma segundo a aparelhagem técnica. Mas isso, mais uma vez, é levado em conta pelo pensamento esclarecido: aparentemente, o próprio sujeito transcendental do conhecimento acaba por ser suprimido como a última reminiscência da subjetividade e é substituído pelo trabalho tanto mais suave dos mecanismos automáticos de controle. ${ }^{177}$

O caráter enviesado desse périplo não permitiu que a civilização ocidental rompesse um ciclo vicioso. Tal como o poder dos anciões não fora páreo para a doutrina mais espiritualizada que

177 Idem. Ibidem; p. 41. 
o sucedeu, o domínio dos conceitos universais sucumbirá a um processo que se autonomizou e deu vida ao positivismo científico. Sob acusação de metafísica e, novamente, de superstição, a grande filosofia burguesa sofrerá na carne a injustiça que perpetrara ao seu passado. Paradoxalmente, essa derradeira forma de abstração revelou com maior clareza a reprodução dos aspectos mais fantasiosos do círculo mitológico do qual o esclarecimento jamais conseguiu emergir. Em DE:

O sentimento de horror materializado numa imagem sólida torna-se o sinal da dominação consolidada dos privilegiados. Mas isso é o que os conceitos universais continuam a ser mesmo quando se desfizeram de todo aspecto figurativo. A forma dedutiva da ciência reflete ainda a hierarquia e a coerção. Assim como as primeiras categorias representavam a tribo organizada e seu poder sobre os indivíduos, assim também a ordem lógica em seu conjunto - a dependência, o encadeamento, a extensão e união dos conceitos - baseia-se nas relações correspondentes da realidade social, da dominação do trabalho. ${ }^{178}$

Ao elaborar uma explicação acerca da vida humana e da organização da coletividade, os mitos aspiravam superar a naturalidade de vínculos primários conferindo-lhes algum significado. Adornava-se o universo das representações com entidades incríveis, cujos poderes excediam consideravelmente a capacidade dos homens para se especular sobre uma realidade distinta da imediaticidade primeira da vida coletiva. Ao menos idealmente, a esperança era que elas pudessem oferecer alternativas à infelicidade e aos perigos de um destino cego. Mesmo quando os homens não conseguissem conter a força da natureza, ao menos o medo diante da morte poderia ser controlado conforme as prescrições ritualísticas. O esclarecimento apostou alto no poder do sujeito, acreditando que a resolução do enigma da Esfinge dissolveria o encantamento trazido pelos mitos. Desde os princípios, encorajar o domínio pelas vias abstratas da razão era consolidar o poder de mando daqueles que já o detinham.

Porém, esse é apenas um dos lados de todo o processo. A razão abstrata e o esclarecimento reinauguram uma nova - e fundamentalmente moderna - era mitológica. De fato, pode-se afirmar que mundo moderno foi desencantado. No entanto, essa caça aos fantasmas produzirá de maneira imanente uma outra espécie de ofuscamento.

Nas formas iniciais de organização do convívio social, a natureza era a instância mais 178 Idem. Ibidem; p. 34. 
poderosa e a existência humana dependia de suas idiossincrasias. Com as sociedades modernas, os sujeitos aparentemente se tornaram senhores de tudo. Entretanto, os indivíduos submetem-se continuamente aos imperativos ditados por uma segunda natureza. Os esforços para libertar a humanidade do jugo do acaso e das relações imediatas tornam-se uma nova imediaticidade - agora produzida pela mediação universal - e transforma, novamente, o destino humano em uma simples questão de sorte ou azar. Em DE:

Nos momentos decisivos da civilização ocidental, da transição para a religião olímpica ao renascimento, à reforma e ao ateísmo burguês, todas as vezes que novos povos e camadas sociais recalcavam o mito, de maneira mais decidida, o medo da natureza não compreendida e ameaçadora - conseqüência da sua própria materialização e objetualização - era degradado em superstição animista, e a dominação da natureza interna e externa tornava-se o fim absoluto da vida. Quando afinal a autoconservação se autonomatiza, a razão é abandonada por aqueles que assumiram sua herança a título de organizadores da produção e agora a temem nos deserdados. A essência do esclarecimento é a alternativa que torna inevitável a dominação. Os homens sempre tiveram de escolher entre submeter-se à natureza ou a natureza ao eu. Com a difusão da economia mercantil burguesa, o horizonte sombrio do mito é aclarado pelo sol da razão calculadora, sob cujos raios gelados amadurece a sementeira da nova barbárie. Forçado pela dominação, o trabalho humano tendeu a cair sob o influxo do mito, levado pela mesma dominação. ${ }^{179}$

\title{
Mundo desencantado?
}

\author{
“(...) o que melhor calculava \\ o fluido aceiro da vida, \\ o que com mais precisão \\ roçava a morte em sua fímbria, \\ o que à tragédia deu número, \\ à vertigem, geometria \\ decimais à emoção \\ e ao susto, peso e medida, (...)"180
}

As sociedades modernas coroaram esse trajeto mágico-religioso milenar. Se para Weber todo o percurso fora marcado essencialmente pela ascensão de uma forma peculiar da razão, a qual se contrapunha a inúmeros tipos alternativos, assentados em bases absolutamente distintas e cujas possibilidades são também tão díspares, Adorno e Horkheimer sublinharam ainda um outro aspecto.

Desde o seu nascedouro, a razão ocidental é indissociável de uma irracionalidade que lhe é inerente. Antes de seu apogeu, tal imbricação violentou o pensamento mitológico e a ela mesma. O destino dos mitos nos é conhecido, e esclarecimento eliminou as últimas instâncias de sua autoconsciência 
crítica. Ignorando tais elementos, ele perdeu suas vergonhas. Talvez ainda lhe faltasse coragem para dizer tudo isto diretamente.

No entanto, se a clareza de suas formulações ocultam uma nova ofuscação, as contradições pelas quais se articula a realidade que o esclarecimento julgou como necessária e ideal são mais difíceis de esconder. Todo o desenvolvimento tecnológico não foi suficiente para garantir um padrão de vida digno a todos, embora haja condições técnicas para tanto. Fossem religiosas ou seculares, as custosas renúncias subjetivas também não surtiram os efeitos que seriam desejáveis. As promessas de um futuro resplandescente são cínicas, e nada disso surpreende. Pois o objetivo do esclarecimento jamais foi condizente com preocupações e interesses realmente humanos, embora ele tenha desempenhado um papel fundamental na estruturação de tais reivindicações. O seu projeto atual nada mais é do que a manutenção do jogo de domínio social que agora pretende se confundir com a inescapabilidade de leis naturais. Em DE:

Os próprios dominadores não acreditam em nenhuma necessidade objetiva, mesmo que às vezes dêem esse nome a suas maquinações. Eles se arvoram em engenheiros da história universal. Só os dominados aceitam como necessidade intangível o processo que, a cada decreto elevando o nível de vida, aumenta o grau de sua impotência. Agora que uma parte mínima do tempo de trabalho à disposição dos donos da sociedade é suficiente para assegurar a subsistência daqueles que ainda se fazem necessários para o manejo das máquinas, o resto supérfluo, a massa imensa da população, é adestrado como uma guarda suplementar do sistema, a serviço de seus planos grandiosos para o presente e o futuro. Eles são sustentados como um exército de desempregados. Rebaixados ao nível de simples objetos do sistema administrativo, que preforma todos os setores da vida moderna, inclusive a linguagem e a percepção, sua degradação reflete para eles a necessidade objetiva contra a qual se crêem impotentes. Na medida em que cresce a capacidade de eliminar duradouramente toda miséria, cresce também desmesuradamente a miséria enquanto antítese da potência e da impotência. ${ }^{181}$

As condições dessa supremacia não se encontram entre as classes dominantes. Seria bastante frustrante investigar as suas causas nas camadas mais ricas da população. Na verdade, o poder não é mais deles, eles apenas assumem os lugares de comando e se beneficiam de seus privilégios. Do burguês mais endinheirado ao trabalhador menos protegido pela seguridade social há um empobrecimento da experiência que perpassa as mais sutis distinções de classe.

A culpa também não reside nos indivíduos, pois a brutalidade que os mantêm sob vigilância

181 Adorno, T. \& Horkheimer, M. Dialética do esclarecimento; p. 49. 
é tão pouco representativa de suas verdadeiras qualidades como o valor de troca o é para os produtos do trabalho humano ${ }^{182}$. Afogado por uma identidade abstrata, o indivíduo moderno nada mais é do que um mero ser genérico vivendo baixo a égide de uma coletividade governada pela força do capital. A perpetuação da moderna divisão do trabalho, também responsável pela diferenciação das habilidades e do conhecimento, alienou os homens e todos os demais objetos sobre os quais se exerce controle.

Na verdade, a causa se refugiaria nos pressupostos da produção material de mercadorias e na sociedade moderna como um todo. Pouco importa viver muitos anos porque o que é balizado socialmente reproduz o que já estava contido em um mundo sempre igual e cuja aparência é de não ter nenhuma saída. Ainda que o espírito busque novas vivências nas artes, o princípio de equivalência tende a apoderar-se inclusive dessa esfera. Por certo o sistema possui algumas brechas. Mas ele é bastante flexível. Ao longo de tantos séculos e por numerosos momentos, o esclarecimento conseguiu transformar os homens em seres maleáveis às exigências mais contraditórias de uma ordem social construída por eles, mas que apenas de forma indireta preocupa-se com a satisfação de suas demandas. Em DE:

\begin{abstract}
O espírito torna-se de fato o aparelho da dominação e do autodomínio, como sempre havia suposto erroneamente a filosofia burguesa. Os ouvidos moucos, que é o que sobrou aos dóceis proletários desde os tempos míticos, não superam em nada a imobilidade do senhor. É da imaturidade dos dominados que se nutre a hipermaturidade da sociedade. Quanto mais complicada e mais refinada a aparelhagem social, econômica e científica, para cujo manejo o corpo já há muito foi ajustado pelo sistema de produção, tanto mais empobrecidas as vivências de que é capaz. Graças aos modos de trabalho racionalizados, a eliminação das qualidades e sua conversão em funções transferem-se da ciência para o mundo dos anfíbios. A regressão das massas, de que hoje se fala, nada mais é senão a incapacidade de ouvir o imediato com os próprios ouvidos, de poder tocar o intocado com as próprias mãos: a nova forma de ofuscamento que vem substituir as formas míticas superadas. (...). A impotência dos trabalhadores não é mero pretexto dos dominantes, mas a conseqüência lógica da sociedade industrial, na qual o fado antigo acabou por se transformar no esforço de a ele escapar. ${ }^{183}$
\end{abstract}

Por mais uma vez é necessário voltar a Weber. Conquanto resguarde muitas especificidades e aponte para direções distintas, um diagnóstico como esse não lhe era completamente estranho. O parentesco é inegável não somente com relação àqueles que, ao final d'A ética, encontravam-se

182 Idem. Ibidem; p. 40. 183 Idem. Ibidem; p. 47. 
entre os “últimos homens”, condenados a traduzir as crenças de outrora em práticas mecânicas. A filiação seria com o indivíduo moderno como um todo.

O vida não lhe faz sentido. A busca irrefreada pela fabricação intelectual de novas religiões não se desgarra do sentimento interno de não haver nenhuma profecia autêntica na qual se possa acreditar de maneira sincera ${ }^{184}$. As soluções políticas formuladas em cátedras universitárias são ainda mais patéticas. Comprometem a honestidade das pesquisas acadêmicas, e não fazem amanhecer nenhuma nova realidade.

A ciência nos coloca em contato com saberes que permitem controlar tecnicamente - pelo cálculo e pela previsão - desde os objetos inanimados até as atividades humanas. Seus procedimentos de pensamento são ferramentas poderosíssimas e seus resultados contribuem em um grau inaudito para a clareza da relação entre os meios e os fins. Finalmente, a humanidade reuniu condições técnicas para colocar a natureza a seus pés. Porém, isso não conduzirá nunca a uma efetividade mais essencial e tampouco promete qualquer vivência arrebatadora.

Pois é um dado incontornável deste período histórico que os conhecimentos devam se basear em conexões empíricas reais, e não imaginados como que brotando das mãos de santos visionários ou de profetas, das cabeças de sábios ou de filósofos. A pretensão de refletir cientificamente sobre um sentido para o acontecer histórico ou natural é insustentável. É vã a filosofia que imagina haver muitos mistérios entre o céu e a Terra. A verdade é que a anatomia do piolho não comprova a existência de deus. Antes, o contrário - ela conduz sim a uma espécie de ateísmo militante. Malgrado as reverências de homens do passado aos cosmos ordenados por divindades, a cultura - e de forma mais viva no Ocidente - condena-se a uma falta de sentido cada vez mais insofismável ${ }^{185}$. Independentemente do que ainda queiram dizer as religiões da salvação ou qualquer outra ética fraternal, a injustiça e a imperfeição são inerentes a uma vida social que se organiza e se reproduz a partir de relações de dominação. Uma simples observação empírica desata com alguma

184 Weber, Max. "Ciência como vocação”; p. 32. 185 Idem. “Consideração intermediária”; p. 355. 
tranquilidade o mais intrincado dos raciocínios teológicos. O destino deste tempo não é outro senão o de um mundo plenamente desencantado, no qual os interesses e os anseios humanos se digladiam intensamente, mas sem poder recorrer à tutela das antigas máscaras religiosas. Em "Ciência como vocação":

\begin{abstract}
O homem civilizado, ao contrário, colocado em meio ao caminhar de uma civilização que se enriquece continuamente de pensamentos, de experiências e de problemas, pode sentir-se "cansado" da vida, mas não "pleno" dela. Com efeito, ele não pode jamais apossar-se senão de uma parte ínfima do que a vida do espírito incessantemente produz, ele não pode captar senão o provisório e nunca o definitivo. Por esse motivo, a morte é, a seus olhos, um acontecimento que não tem sentido. E porque a morte não tem sentido, a vida do civilizado também não o tem, pois a "progressividade" despojada de significação faz da vida um acontecimento igualmente sem significação. ${ }^{186}$
\end{abstract}

Assim, ao lado da compreensão da dinâmica interna das ideias e dos fenômenos religiosos, o escopo do conceito weberiano de desencantamento do mundo abarca ainda um diagnóstico histórico da própria modernidade europeia ${ }^{187}$. O funcionamento da ciência torna mais evidente esse seu outro significado. Fazer o espírito imperar sobre uma natureza desencantada é também o seu único objetivo. Se com a reforma protestante a condição de criatura é irremediável e o mundo constitui-se em um arranjo no qual se multiplica as possibilidades de pecado, o cientista moderno não enxerga qualquer sentido imanente em suas observações empíricas. Em ambos os casos, houve uma abstração radical. Castigar a imagem do santo por uma graça não atendida é uma infâmia terrível, e o fiel não tem meios mágicos de alterar os desígnios de deus. Imaginar que um evento histórico ou natural seja portador de algum sentido é uma metafísica tola como todas as demais.

A ciência desvela o encadeamento causal existente entre os seus objetos - e não há nada de sobrenatural nesses vínculos. Ainda que restassem muitos mistérios na natureza e na sociedade, os saberes que lidam com a vida social não ignoram as suas possíveis influências sobre a conduta humana, mas não devem se esquecer de que milagres não existem. Por certo que a ciência possa

186 Idem. “Ciência como vocação”; p. 31.

187 A esse respeito, Pierucci é certeiro: "Uma vez que o que a ciência visa com sua racionalidade formal referente a fins [Zweckrationalität] é o domínio técnico do mundo natural pela tecnologia, opondo com isso aguerrida aversão e resistência à expansão, no cotidiano, da racionalidade substantiva com relação a valores [Wertrationalität], perde seu chão a pertinência mesma da questão do sentido, pois dele, no fim das contas, a ciência que preza seu nome não tem mesmo nada a dizer - y compris o sentido dela própria. Ela que pretende tudo calcular, prever e dominar, não é capaz de definir nenhum valor, sequer mesmo de dizer se vale a pena ser cientista e dedicar a vida à pesquisa.” Pierucci, Antonio. O desencantamento do mundo; p. 152. 
falhar e imputar relações causais falsas ou desconhecer momentaneamente efeitos sujeitos a uma regularidade mais ampla. Porém, ela nunca estará autorizada a apelar ao sacrifício do intelecto. Questões existenciais são postas de lado e uma espécie de pragmatismo desencantado parece se colocar em cena. Sem poder socorrer-se do auxílio de qualquer entidade mágica, não se espera mais que uma pedra - por preciosa que seja - decida sobre o sucesso de uma ventura ou sobre as variações climáticas. É chegado o tempo em que se recorre à técnica e à previsão para desvendar os mecanismos causais realmente atuantes, e pelo seu controle metódico conseguir dominar a tudo.

A indagação a respeito do direito dos homens tornarem-se senhores da natureza não abala suas convicções. Essa pergunta não deve sequer lhe ser endereçada. A ausência de um sentido transcendente que perpasse a atividade dos cientistas não é algo que os envergonhe ou revele sua imaturidade. Tampouco é muito específico, porque se verifica uma inquietação similar em diversos âmbitos das sociedades modernas. É o próprio mundo que não aceita mais as imposições de significado de um plano pretensamente superior. A ciência moderna somente reúne as melhores condições para conviver com tal ordenamento da vida coletiva, e nos nutre dos meios mais eficientes para tratar da natureza concebida em tais termos. Em “Ciência como vocação”:

\footnotetext{
A intelectualização e a racionalização crescentes não equivalem, portanto, a um conhecimento geral crescente acerca das condições em que vivemos. Significam, antes, que sabemos ou acreditamos que, a qualquer instante, poderíamos, bastando que o quiséssemos, provar que não existe, em princípio, nenhum poder misterioso e imprevisível que interfira com o curso de nossa vida; em uma palavra, que podemos dominar tudo, por meio da previsão. Equivale isso a despojar de magia o mundo. Para nós não mais se trata, como para o selvagem que acredita na existência daqueles poderes, de apelar a meios mágicos para dominar os espíritos ou exorcizá-los, mas de recorrer à técnica e à previsão. ${ }^{188}$
}

De acordo com Weber, o surgimento do conceito na Grécia antiga e o desenvolvimento de técnicas de experimentação racional durante o Renascimento contribuíram fortemente para tal desenlace. Com certos ajustes, eles serão os instrumentos feitos sob medida a fim de resguardar o pensamento de tentações indevidas. Quanto ao conceito, embora houvesse uma impregnação inicial com categorias políticas, ele é uma ferramenta forjada para submeter as elaborações teóricas ao rigor do formalismo. Inspirado por procedimentos racionais, seguros e reproduzíveis, o 
encadeamento das ideias libertou-se das pressões da falta de compromisso com a lógica. A explicação científica de um evento não se coaduna com as reviravoltas próprias às contradições e às antinomias do pensamento. Ela estabelece-se pela imanência de uma relação de imputação causal examinada consoante as regras da composição conceitual.

Por seu turno, o controle metódico sobre os experimentos nasceu embaralhado às criações artísticas, cujo flerte com o sublime fazia sua ambição primeira extrapolar em seus direitos. A possibilidade de realizar observações em um ambiente previamente isolado de influências externas permitiria à atividade intelectual se realizar com maior acurácia, e seus resultados tornaram-se verdadeiramente comparáveis. Dentro de um laboratório não há espaço para alvoroço com relação aos milagres. Nem todas as variáveis de uma equação são de fácil solução, e o peso de cada uma delas pode ser eventualmente sobrevalorizado. Entretanto, tais lacunas não são preenchíveis à força ou pela imaginação desprovida de base empírica - o Deus ex machina não será nunca um argumento válido. Segundo Weber:

A essa descoberta do espírito helênico associou-se, depois, o segundo grande instrumento do trabalho científico, engendrado pelo Renascimento: a experimentação racional. Tornou-se ela meio seguro de controlar a experiência, sem o qual a ciência empírica moderna não teria sido possível. Por certo que não se haviam feito experimentos muito antes dessa época. Haviam tido lugar, por exemplo, experiências fisiológicas, realizadas na Índia, no interesse da técnica ascética da Ioga, assim como experiências matemáticas na antiguidade helênica, visando fins militares e, ainda, experiências na Idade Média, com vistas à exploração de minas. Foi, porém, o Renascimento que elevou a experimentação ao nível de um princípio da pesquisa enquanto tal. Os precursores foram, incontestavelmente, os grandes inovadores no domínio da arte: Leonardo da Vinci e seus companheiros e, particularmente e de maneira característica no domínio da música, os que se dedicaram à experimentação com o cravo, no século XVI. Daí, a experimentação passou para o campo das ciências, devido sobretudo, a Galileu e alcançou o domínio da teoria, graças a Bacon; foi a seguir, perfilhada pelas diferentes universidades do continente europeu, de início e principalmente pelas da Itália e da Holanda, estendendo-se à esfera das ciências exatas. ${ }^{189}$

Para ambos os casos houve uma depuração obrigatória antes de seu uso moderno. A política é sim um arranjo formado por meio de numerosas lutas sociais e, ainda que um longo período de estabilidade seja possível, o desfecho de tais disputas nunca será algo necessário ou suscetível a um apaziguamento definitivo. A lição que se aprende dos gregos não é aquela que daria acesso à verdade eterna - a qual não se desvanece tal como a cega ação humana -, mas a sabedoria de 189 Idem. Ibidem; p. 33-34. 
reconhecer o princípio da não contradição como condição de possibilidade de qualquer elaboração conceitual. Pouco importa que a democracia moderna não corresponda ao ideal de liberdade e de igualdade substantivas que muitos movimentos progressistas esmeram-se em tentar transformá-la. A ciência também não poderá emitir julgamentos morais que desabonem uma tirania violenta, ou que se maravilhem ante o utopismo de uma liberdade idealmente imaculada. O que lhe concerne é explicitar os pressupostos e as consequências de cada regime político - deixando aos homens de ação a responsabilidade por suas escolhas e por suas preferências.

Com relação às artes, a cisão também há de ser completa. Elas são animadas por preocupações radicalmente distintas. No âmbito das produções artísticas, o termo progresso não passa de uma ilusão ingênua e deslocada. Para a ciência, ele é provavelmente o seu significado mais orgânico. O gênio de um artista não é comparável ao de nenhum outro. A técnica de sua obra pode ser visivelmente rudimentar em relação aos desenvolvimentos posteriores. Não obstante, o valor do resultado estético não se depreende da atualidade dos meios técnicos disponíveis. A ciência, por outro lado, não respeita sequer suas próprias tradições. Apesar de certas veleidades individuais, a ambição - e o destino - do especialista é ver o resultado de suas pesquisas serem ultrapassados continuamente. Pois é dessa maneira que o conhecimento progride, e somente assim ele se torna racional para o Ocidente desencantado. Segundo Weber:

O trabalho científico está ligado ao curso do progresso. No domínio da arte, ao contrário, não existe progresso no mesmo sentido. Não é verdade que uma obra de arte de época determinada, por empregar recursos técnicos novos ou novas leis, como a da perspectiva, seja, por tais razões, artisticamente superior a uma outra obra de arte elaborada com ignorância daqueles meios e leis, com condição, evidentemente, de que sua matéria e forma respeitem as leis mesmas da arte, o que vale dizer com a condição de que seu objeto haja sido escolhido e trabalhado segundo a essência mesma da arte, ainda que não recorrendo aos meios que vêm a ser evocados. Uma obra de arte verdadeiramente “acabada” não será ultrapassada jamais, nem jamais envelhecerá. ${ }^{190}$

Decompor metodicamente os seus materiais, sopesar a influência de acontecimentos insuspeitos e perscrutar teoricamente encadeamentos de eventos são as tarefas da ciência ocidental. Não se lhe exige mais e nem menos do que isso. A prática intelectual sente repercussões similares às desencadeadas pela burocratização da moderna empresa capitalista. Em ambos os casos, tais 190 Idem. Ibidem; p. 28. 
processos são também portadores de inegáveis vantagens técnicas. O espírito mudará, mas não se pode dizer que ele esteja atrofiado. O entendimento é frio, e há alguma verdade na condenação de jovens tão desconfiados com certa artificialidade das abstratas construções intelectuais modernas. O pecado deles, no entanto, é não enxergar o que se ganha com tal situação.

As imposturas religiosas não encontram mais lugar público. Todo santo tem pés de barro, e qualquer ídolo de outrora mostra-se profanável. Que os verdadeiros profetas já não mais existam é uma realidade difícil de esconder. O que não se pode permitir é que as gerações - as novas, mas também as do presente - temam o significado de tal ausência ${ }^{191}$. Deve-se, pelo contrário, investigar a fundo a sua essência e seus fundamentos mais elementares. É preciso conhecê-lo às minucias e, assim, dar-se conta de suas potencialidades latentes e também de seus limites internos. Porque será sempre falsa a alternativa que diga ser capaz de fugir desse fado.

Se olhássemos atentamente, Abraão e os velhos camponeses, cujas existências estariam contidas dentro do círculo da vida imediata, talvez não fossem assim tão satisfeitos ao cabo de suas jornadas. Independentemente da verdade de tal anacronismo, não há dúvidas sobre os vazios que persistem na vida do homem moderno. Seus feitos mais notáveis dificilmente sobreviverão muitos anos após o seu perecimento físico. O domínio técnico sobre a vida não leva à felicidade. É verdade que já não se vive mais baixo os estritos limites de tabus religiosos e de convenções sociais enfeitiçadas, mas nada garantirá um assossego às nossas almas. A vocação para ser moderno exige que se olhe de frente e se retire as vantagens possíveis deste progresso sem termo, cujo nome não é outro senão o do próprio desencantamento. Segundo Weber:

O destino de nosso tempo, que se caracteriza pela racionalização, pela intelectualização e, sobretudo, pelo “desencantamento do mundo” levou os homens a banirem da vida pública os valores supremos e mais sublimes. (...). A quem não é capaz de suportar virilmente o destino de nossa época, só cabe dar o conselho seguinte: volta em silêncio, sem dar a teu gesto a publicidade habitual dos renegados, com simplicidade e recolhimento, aos braços abertos e cheios de misericórdia das velhas Igrejas. Elas não tornarão penoso o retorno. De uma ou de outra maneira, quem retorna será inevitavelmente compelido a fazer o "sacrifício do intelecto". E não serei eu quem o condene, se ele tiver, verdadeiramente, força para fazê-lo. ${ }^{192}$

191 Idem. Ibidem; p. 48. 192 Idem. Ibidem; p. 51. 
De uma forma distinta, o tema weberiano da perda de sentido reaparece nos escritos dos frankfurtianos. Na verdade, a questão é revisitada e passa a ser interpretada de outra maneira. Diretamente, se Horkheimer durante os anos de 1930 a enfrentava por meio de uma luta ideológica no campo da cultura e da ciência, a DE dá impressão de se voltar também à análise das práticas sociais que conduziram a tal sentimento de uma vida sem significado. Muito embora aquela ainda seja uma batalha a ser disputada, ela mostrou-se enviesada em suas bases, pois o próprio campo de embate - a razão - deveria também ser radicalmente reavaliado.

O objetivo não será tanto uma denúncia das malfadadas consequências subjetivas próprias ao mundo moderno, mas sim a crítica à sociedade que desencadeia tal resultado por suas formas de interação social mais corriqueiras. A crítica à razão como dominação da natureza parece problematizar explicitamente alguns dos pressupostos até então não questionados, mesmo entre os intelectuais mais progressistas.

Assim, o diagnóstico da perda de sentido parece ser desdobrado internamente. De acordo com Adorno e Horkheimer, o desencantamento do mundo era sim o projeto do esclarecimento. Espelhando e constituindo uma nova compreensão da natureza e do sujeito, a atividade intelectual também experimentou certas mudanças. Porém, menos do que se identificar com uma postura exorcizadora de deuses e de demônios, o pensamento moderno propaga de maneira imanente e ao arrepio de sua vontade uma enigmática ilusão fantasmagórica. A causa desse fascínio não resulta de um constrangedor vacilo dos cientistas ou da contaminação de seus experimentos por suas crenças privadas - ele tampouco é verdadeiramente consciente. Presas às exigências de autovalorização do capital e dependentes de uma estrutura de dominação social que as perpetue, as sociedades modernas põem em cena um mecanismo inverso de reencantamento ${ }^{193}$. A coisificação que afeta o

193 A esse respeito, em “Dialética, estruturalismo, pré(pós)-estruturalismo”, Ruy Fausto afirma sobre a teoria social weberiana: "Em Weber, há uma espécie de convergência entre as exigências metodológicas e as teses substantivas, no sentido da eliminação de toda 'fantasmagoria'. Exigência de método: é preciso clarificar absolutamente os conceitos, o que para Weber significa subjetivar (no sentido de que é preciso pôr os agentes, pois só os agentes são objetivos). Tese substantiva: o capitalismo é o mundo desencantado, mundo em que desapareceram as representações 'mágicas'. Forma (método) e conteúdo (tese do capitalismo como mundo desencantado) pressionam no sentido de um discurso 'redutor', e rigorosamente aufklärer. O problema é que há no capitalismo alguma coisa como um mundo encantado, e que esse mundo encantado é em parte (num dos seus momentos) um mundo objetivo. 
pensamento - e fez dele pagão - advém do próprio fetiche da mercadoria, e encanta todas as demais

formas de sociabilidade.

Conquanto tal fantasmagoria objetiva não seja capaz de conferir significado genuíno a nada,

ela desfoca o nosso olhar, condiciona os nossos julgamento e ilude as nossas percepções ${ }^{194}$. Não se

trata, no entanto, unicamente de desvelar o engodo de uma sociedade sustentada pela falsificação

ideológica da realidade. Indo às suas raízes, a crítica tem que perscrutar a própria forma social que

deturpa nossas representações e nossos sentimentos ${ }^{195}$. De acordo com os frankfurtianos, nada

haverá de desencantado em torno de tais práticas. Em DE:

Ao desencantar um mundo objetivamente encantado, o aufklärer Weber é vítima da dialética da Aufklärung (tal como Marx já a conhecia). O discurso aufklärer de Weber corre o risco de 'encantar', isto é, de mistificar, porque clarifica o que não é objetivamente claro, descanta o que é objetivamente encantado.” Dialética Marxista, Dialética Hegeliana: a produção do capitalismo como circulação simples; p. 151.

194 Como um momento fundamental da inflexão teórica desencadeada pela DE, Habermas aponta - a meu ver, corretamente - para o esgotamento de uma espécie tradicional de crítica à ideologia em Adorno e Horkheimer. Segundo Habermas: “Com o conceito de 'razão instrumental', Horkheimer e Adorno querem acertar as contas com um entendimento calculador que usurpou o lugar da razão. Esse conceito deve, ao mesmo tempo, relembrar que a racionalidade com respeito a fins, empertigada em totalidade, estreita a diferença entre aquilo que pretende ter validade e aquilo que é útil para a autoconservação, demolindo assim aquela barreira entre validade e poder, anulando aquela diferenciação conceitual básica que a apreensão moderna do mundo acreditava dever a uma superação definitiva do mito. A razão, enquanto razão instrumental, assimilou-se ao poder e renunciou, desse modo, à sua força crítica - este é o último desvelamento de uma crítica à ideologia aplicada a si mesmo. Esta descreve, contudo, a autodestruição da capacidade crítica de modo paradoxal, visto que no instante da descrição ainda tem de fazer uso da crítica que declarou estar morta. Ela denuncia o esclarecimento que se tornou totalitário com os meios do próprio esclarecimento.” Habermas, Jürgen. O discurso filosófico da modernidade; p. 170. Contudo, não assumo os demais desdobramentos de sua análise sobre a DE. Se é certo que esse livro inaugura uma interpretação mais radical acerca da razão e das sociedades modernas, nem por isso suas reflexões desembocariam em uma aporia teórica. Na verdade, Habermas parece exigir do pensamento desses frankfurtianos que satisfaça os requisitos de seu modo peculiar de compreender a vida social. A esse respeito, segundo Steinert: "Dito por outros termos, crítica à ideologia não significa a comprovação de que o outro sofre de ofuscamento enquanto se é subjetivamente consciente, ela também não significa a contraposição de uma moral superior ou de uma empedernida utopia para formular uma crítica da dominação social;, como reflexividade, a crítica à ideologia, que identifica o conflito social, no qual se encontra o próprio conteúdo objetivo de sua crítica - e nunca como pessoa, mas como representante de uma posição social determinada. Como reflexividade, a crítica à ideologia se refere às formações históricas das classes e de seus interesses. Nesse sentido, não é necessário nenhum fundamento normativo exterior para a teoria crítica da sociedade, que para Habermas estaria em primeiro lugar em seu Teoria do agir comunicativo, na qual ele enxerga uma alternativa superior.” Steinert, Heinz. Das Verhängnis der Gesellschaft und das Glück der Erkenntnis; págs. 37-38.

195 Na verdade, a inflexão trazida pela DE pode ser entendida como uma tentativa de fundar uma interpretação voltada a perscrutar as torções peculiares ao fetichismo da mercadoria. Nesse sentido, as considerações de Zizek a respeito da maneira pela qual a crítica marxista do fetichismo da mercadoria e a interpretação dos sonhos da psicanálise freudiana parecem se adequar às intenções de Adorno e Horkheimer com a DE. Segundo Zizek: "Existe uma homologia fundamental no processo interpretativo de Marx e Freud, na abordagem que ambos fazem do 'segredo' da mercadoria ou do sonho. Nos dois casos, deve-se evitar a cegueira, o fascínio propriamente fetichista do 'conteúdo' oculto por trás da forma: o 'segredo' a ser desvendado pela análise não é o conteúdo dissimulado pela forma (forma do sonho, forma mercadoria), mas, muito pelo contrário, é essa própria forma. (...). É a mesma coisa com a mercadoria: o verdadeiro problema não é penetrar no 'núcleo oculto' da mercadoria, na determinação de seu valor pela quantidade de trabalho despendido para sua produção, mas em explicar porque o trabalho assumiu a forma do valor de uma mercadoria, porque só pode afirmar seu caráter social sob a forma-mercadoria de seu produto. Zizek, Slavoj. O mais sublime dos histéricos: Hegel com Lacan; p. 131. 
O animismo havia dotado a coisa de uma alma, o industrialismo coisifica as almas. O aparelho econômico, antes mesmo do planejamento total, já provê espontaneamente as mercadorias dos valores que decidem sobre o comportamento dos homens. A partir do momento em que as mercadorias, com o fim do livre intercâmbio, perderam todas suas qualidades econômicas salvo seu caráter de fetiche, este se espalhou como uma paralisia sobre a vida em sociedade em todos os seus aspectos. (...). A figura demoniacamente distorcida, que as coisas e os homens assumiram sob a luz do conhecimento isento de preconceitos, remete de volta à dominação, ao princípio que já operava a especificação do mana nos espíritos e divindades e fascinava o olhar nas fantasmagorias dos feiticeiros e curandeiros. A fatalidade com que os tempos pré-históricos sancionavam a morte ininteligível passa a caracterizar a realidade integralmente inteligível. O pânico meridiano com que os homens de repente se deram conta da natureza como totalidade encontrou sua correspondência no pânico que hoje está pronto a irromper a qualquer instante: os homens aguardam que este mundo sem saída seja incendiado por uma totalidade que eles próprios constituem e sobre a qual nada podem. ${ }^{196}$

Tipicamente moderna, a ciência é examinada quase como em uma etnografia. O que na magia representou algum limite à ação instrumental e ao domínio dos homens sobre a natureza foi extirpado pelos conceitos positivistas. Não restou nada da especificidade do intercâmbio mágico com o sagrado senão a proliferação de novos tabus, a adoração de rituais sem sentido e a prescrição estrita de padrões de comportamentos a serem observados na atividade cotidiana dos cientistas. É uma prática social como essa - cuja forma mais generalizada e significativa é o trabalho ${ }^{197}$ - que produzirá essa vivência esvaziada de sentido, revelando a profunda inadequação comuns a todos os indivíduos modernos com as atividades mais ordinárias e a incontornável experiência de mal-estar com a própria sociabilidade capitalista.

Entre as mais diversas correntes do pensamento científico, o positivismo porte talvez a sua

196 Adorno, T. \& Horkheimer, M. Dialética do esclarecimento; p. 40.

197 Embora eu divirja de suas considerações, Postone afirma que Adorno e Horkheimer foram incapazes de problematizar a especificidade histórica do trabalho no capitalismo moderno. Apesar de uma composição muito mais sofisticada, o conceito frankfurtiano de dominação da natureza partilharia da mesma insuficiência teórica da noção de trabalho própria ao marxismo tradicional. Segundo Postone: "Em Dialética do esclarecimento (1944), e Eclipse da razão ('Zur Kritik der instrumentellen Vernunft', 1946), a avaliação de Horkheimer da relação entre produção e emancipação torna-se inequivocamente mais negativa. (...). Ele afirma que a natureza da dominação social tornara-se progressivamente uma função da razão tecnocrática ou instrumental, a qual ele funda no 'trabalho'. Sua noção de forma, no entanto, permanece vazia. Pela produção ter se tornado o reino da não-liberdade, Horkheimer assevera que o contemporâneo declínio do indivíduo e a dominação da razão instrumental não devem ser atribuídos à técnica ou à produção enquanto tal, mas à forma da relação social na qual elas aconteceram Ele trata o desenvolvimento tecnológico em uma maneira histórica e sociologicamente indeterminada, como dominação da natureza. (...) Uma tal noção de forma social apenas consegue ser relacionada extrinsecamente com a tecnologia, nos termos do uso pelo qual ela foi aplicada; ela não pode, no entanto, relacionar-se intrinsecamente com o modo de produção. Já uma explicação social da instrumentalização do mundo, oposta a uma técnica, pode apenas ser feita sob as bases de uma relação intrínseca. Assim, embora a renúncia de Horkheimer que a dominação da razão instrumental e a destruição da individualidade possa ser explicada em termos sociais e não apenas atribuído à produção enquanto tal, eu argumentaria que ele, de fato, não associar a razão instrumental e o 'trabalho'.” Postone, Moishe. Time, labor and social domination; p. 117. Todavia, essa avaliação de Postone me parece equivocada. Ao contrapor a ciência e a magia na DE, Adorno e Horkheimer não abandonaram uma problematização histórica de sua crítica. 
elaboração mais cristalina. Para ele todo o universo é habitado por dados justapostos, e até mesmo os conceitos de causa e de efeito lhe soam atualmente como superstição. O objeto da ciência não é investigado como sedimento de inúmeras mediações sociais, as quais revelariam o sentido social, histórico e humano atado a tais elementos. Todas as suas qualidades são dissolvidas em favor da elaboração de um tipo de saber cujo grau de abstração é radicalíssimo. A existência do factual é elevado às alturas e o seu aspecto de imediaticidade confirma-se pelas abstratas relações espaçotemporais ditadas pela razão. O que se perde com isso é a possibilidade da negação determinada de cada dado imediato da percepção. O saldo é a hipostasiação - tanto no pensamento como na efetividade social - de um arranjo social integralmente histórico.

O capitalismo moderno torna-se, ele mesmo, a sua própria e justa medida. O retorno ao mito não é mera metáfora. Tal como o feiticeiro do mundo primitivo, o círculo ritual traçado pelo censor positivista não tolera ser transgredido. Se os cultos mágicos tinham em vista a natureza que se repetia, o atual triunfo da racionalidade ocidental e do formalismo lógico não difere em qualidade. Ele também crê na superioridade da repetição daquilo que se porta consoante a imanência da legalidade própria à ordem coletiva. Os antagonismos sociais continuam a avolumar-se no campo da prática, mas as formulações teóricas positivistas não são capazes de refletir sobre tais movimentos. Na verdade, eles são ignorados a fim de fazer prevalecer a narrativa de que já não haveria mais nenhuma contradição objetiva.

O positivismo tropeça diante de dados que vez por outra ultrapassam a sua obtusa jurisdição intelectual. No entanto, independente de como se comportem os fatos, esta verdade que se entende como um sistema coerente e unitário subverte até a materialidade de seus objetos ao proclamar-se como a nova palavra a ser seguida. Exigindo uma devoção quase religiosa aos seus princípios lógicos, as múltiplas possibilidades de outrora foram ainda mais recalcadas no plano do pensamento. Em DE:

Desse modo, o esclarecimento regride à mitologia da qual jamais soube escapar. Pois, em suas figuras, a mitologia refletira a essência da ordem existente - o processo cíclico, o destino, a dominação do mundo - como a verdade e abdicara da esperança. Na 
pregnância da imagem mítica, bem como na clareza da fórmula científica, a eternidade do factual se vê confirmada e a mera existência expressa como o sentido que ela obstrui. O mundo como um gigantesco juízo analítico, o único sonho que restou de todos os sonhos das ciências, é da mesma espécie que o mito cósmico que associava a mudança da primavera e do outono ao rapto de Perséfone. A singularidade do evento mítico, que deve legitimar o evento factual, é ilusão. (...). Com o enrijecimento da consciência do tempo, o evento foi fixado como tendo ocorrido uma única vez no passado, e tentou-se apaziguar ritualmente o medo da morte em cada novo ciclo das estações com o recurso a algo ocorrido há muito tempo. Mas a separação é impotente. Em virtude da colocação dessa ocorrência única do passado, o ciclo assume o caráter do inevitável, e o medo irradia-se desse acontecimento antigo para todos os demais como sua mera repetição. A subsunção do factual, seja sob a pré-história lendária, seja sob o formalismo matemático, o relacionamento simbólico do presente ao evento mítico no rito ou à categoria abstrata na ciência, faz com que o novo apareça como algo predeterminado, que é assim na verdade o antigo. Quem fica privado da esperança não é a existência, mas o saber que no símbolo figurativo ou matemático se apropria da existência enquanto esquema e a perpetua enquanto tal. ${ }^{198}$

Por conta desse descaminho, a razão ocidental teve de separar-se ainda anteriormente das artes. A separação talvez fosse um tanto inevitável, mas o tamanho da ruptura espanta. Também parente da magia, a arte é um outro âmbito de interação social no qual se reúnem o campo da prática com o das representações simbólicas. Ao utilizarem-se de seus meios, os homens lidam com a natureza que os circunda ou com a inscrita em seus corpos, um vasto repertório de estilos e de padrões estéticos, certas elaborações conceituais e com conjuntos de instrumentos. Não convém prolongar-me em tais aspectos, mas sim encaminhar a discussão para o que mais importa nesta pesquisa.

Se a ciência moderna opera uma duplicação da realidade que nada mais é do que a projeção idealizada de como essa tal efetividade gostaria de se apresentar publicamente, a arte - quando verdadeira - relaciona sujeito e objeto de um modo próprio. Não se trata de edulcorar a realidade por suas criações simbólicas, mas de fomentar uma experiência crítica que explicite a falsidade de todo um conluio. A arte teve de renunciar à pretensão de conhecer intuitivamente a natureza. Todavia, isso não significa dizer que ela esteja apartada do que possa ser considerado racional. Ante a dócil duplicação científica do mundo, as obras de arte autênticas conseguem ultrapassar simbolicamente a barreira daquilo que já é assim e não de outro modo ${ }^{199}$.

De acordo com Adorno e Horkheimer, sobretudo em sua interpretação neopositivista, a

198 Adorno, T. \& Horkheimer, M. Dialética do esclarecimento; p. 39. 199 Idem. Ibidem; p. 31. 
ciência quis se acomodar em um mero esteticismo, cujo sistema de signos dissocia-se de maneira definitiva de qualquer intenção de pensar a realidade social como um construto histórico ou mesmo de expressar suas contradições imanentes. A ciência moderna parece, portanto, ter aprendido a lição de seus próprios pressupostos. A apreensão conceitual da objetividade concebida como simples matéria amorfa faz minguar progressivamente o espírito. Sua derradeira aspiração talvez fosse desenvolver técnicas refinadas para inaugurar, finalmente, uma época de copiabilidade integral.

A arte, por seu turno e ao menos como possibilidade, ressuscita a esperança de relacionar-se com a natureza de uma forma distinta e superior. Sujeito e objeto confundem-se continuamente, pois eles não são duas instâncias ceifadas pela abstração. O primeiro não se imagina como a instância absoluta, e não condena o seu outro ao silêncio. Tal como afirmava Weber, a produção estética não é avaliável a partir de critérios utilitários e um termo como o de progresso não lhe diz respeito. Por um lado, isso representaria a abdicação da arte em conseguir intervir nos assuntos cotidianos ou nas grandes questões públicas - a poesia não ganhou nenhuma guerra e nem fez nenhuma invenção ${ }^{200}$. Contudo, foi justamente esse recolhimento forçado que lhe permitiu ser diferente. Desgarrada do influxo hegemônico, ela recupera o que a magia tinha de específico e, em seus grandes momentos, ensaia agir daquele modo de forma consciente. Em DE:

A razão e a religião declaram anátema o princípio da magia. Mesmo a distância renunciadora da vida, enquanto arte, ele permanece desonroso; as pessoas que o praticam tornam-se vagabundos, nômades sobreviventes que não encontram pátria entre os que se tornaram sedentários. A natureza não deve ser mais influenciada pela assimilação, mas deve ser dominada pelo trabalho. A obra de arte ainda tem em comum com a magia o fato de estabelecer um domínio próprio, fechado em si mesmo e arrebatado ao contexto da vida profana. (...). Esta renúncia coloca a imagem pura em oposição à realidade mesma, cujos elementos ela supera retendo-os (aufhebt) dentro de si. Pertence ao sentido da obra de arte, da aparência estética, ser aquilo em que se converteu, na magia do primitivo, o novo e terrível: a manifestação do todo no particular. Na obra de arte volta sempre a se realizar a duplicação pela qual a coisa se manifestava como algo de espiritual, como exteriorização do mana. É isto que constitui sua aura. ${ }^{201}$

Entretanto, depois de passado tanto tempo entretecida em elementos mágico-religiosos, é chegado o momento em que a dominação da natureza arrisca a se afirmar sem tais adereços. Em épocas anteriores, eles estabeleceram algumas resistências e barreiras, todas distintas em graus e em

200 Idem. Ibidem; p. 32.

201 Idem. Ibidem; p. 32. 
potencialidades. Com o positivismo já não há mais nada a ser interposto entre a norma social e a ação individual ${ }^{202}$. O indivíduo moderno é coisificado. O ideal do eu visa exterminar todos os seus mais persistentes vestígios naturais como algo que ainda soe pecaminoso. Um sujeito transcendental - e ultra abstrato - assenta-se como a única instância legisladora da conduta humana. Embora a autoconservação dessa impostura não tenha nada de sagrada, deve-se respeitá-la com um fervor maior do que o devotado ao mais santos dos mandamentos - fugir a tais determinações é mais insano do que o alcoolismo ${ }^{203}$. Não pelas benesses prometidas, mas porque imaginam seguir recomendações puramente racionais.

Na verdade, esta razão desfigurada pela civilização ocidental mutila a psique e o corpo humanos. A exortação protestante do trabalho identifica-se com a imagem de uma bota pisando sobre um verme ${ }^{204}$. Como qualquer outra mercadoria, o homem está plenamente secionado entre o seu valor de uso e o seu valor de troca. O primeiro deve somente se resignar em ser o simples suporte material do conjunto, e o segundo - conquanto abstrato - é o que existe objetivamente. As pulsões individuais devem ser unificadas, pois o sujeito moderno não pode se distrair durante sua jornada de trabalho. Que ela tenha se expandido para além das horas regulamentadas nos contratos de prestação de serviços, apenas confirma a sabedoria da marcha universal. Não há mais tempo livre, desde que os prazeres tornaram-se entretenimento e os exercícios físicos em condicionamento para uma rotina abruptamente mais estafante. Em DE:

O progresso reservou a mesma sorte tanto para a adoração quanto para a queda no ser natural imediato: ele amaldiçoou do mesmo modo aquele que, esquecido de si, se abandona tanto ao pensamento quanto ao prazer. O trabalho social de todo indivíduo está mediatizado pelo princípio do eu na economia burguesa; a um ele deve restituir o capital aumentado, a outro a força para um excedente de trabalho. Mas quando mais o processo da autoconservação é assegurado pela divisão burguesa do trabalho, tanto mais ele força a auto-alienação dos indivíduos, que têm que se formar no corpo e na alma segundo a aparelhagem técnica. Mas isso, mais uma vez, é levado em conta pelo pensamento esclarecido: aparentemente, o próprio sujeito transcendental do conhecimento acaba por ser suprimido como a última reminiscência da subjetividade e é substituído pelo trabalho tanto mais suave dos mecanismos automáticos de controle. ${ }^{205}$

202 Idem. Ibidem; p. 41.

203 Idem. Ibidem; p. 41.

204 Idem. Ibidem; p. 216.

205 Idem. Ibidem; p. 41. 
A injustiça dessa troca de equivalentes permanece sendo inegável. No entanto, o prejuízo não se esgota só em quem é o mais logrado economicamente. Se o passado da civilização ocidental correspondeu a um progressivo esvaziamento de qualquer valor imanente da natureza, a ciência moderna preparou - sobretudo em suas correntes hegemônicas - um pensamento igualmente exaurido de significado e, portanto, apto para lidar com uma objetividade sem sentido.

O sujeito como simples unidade abstrata e essa nova unidade da natureza se retroalimentam. Enquanto o primeiro nasce ao reconhecer o poder como princípio de todas as relações, a segunda não é nada além do caos que se submete à classificação. A relação será unívoca e previamente determinada. Não haverá mais espaço para confusões, variações e misturas. O sujeito é a instância racional e a dotadora de sentido. O átomo será apenas um espécie da matéria, e a cobaia um simples exemplar no laboratório ${ }^{206}$.

A taxionomia projetada pelo pensamento ordenador não corresponde nem à objetividade construída pelos homens e menos ainda àquilo que existe para além das nossas criações. Todavia, como não se reconhece na natureza nenhum direito à palavra, a vida social compromete-se em reconfigurar o que lhe aparece como desforme. Orgulhosos de uma espécie de missão redentora, os indivíduos fazem o mesmo com suas interioridades. O saldo inevitável é o custo de uma vigilância que não tem fim e nem significado genuíno. Em DE:

Mas este pensamento, resguardado dos sonhos de um visionário nas diversas disciplinas volta-se contra o próprio sujeito pensante; nada sobra dele senão justamente esse eu penso eternamente igual que tem que poder acompanhar todas as minhas representações. Sujeito e objeto tornam-se ambos nulos. O eu abstrato, o título que dá o direito a protocolar e sistematizar, não tem diante de si outra coisa senão o material abstrato, que nenhuma outra propriedade possui além da de ser um substrato para semelhante posse. A equação do espírito e do mundo acaba por se resolver, mas apenas com a mútua redução de seus dois lados. Na redução do pensamento a uma aparelhagem matemática está implícita a ratificação do mundo como sua própria medida. O que aparece como triunfo da racionalidade objetiva, a submissão de todo ente ao formalismo lógico, tem por preço a subordinação obediente da razão ao imediatamente dado. ${ }^{207}$

É certo que, por outro lado, permanece latente a alternativa aberta para um outro destino. Ainda que o esclarecimento tenha confundido as coisas ao exterminar por séculos deuses e 
demônios, ele também permite imaginar uma relação distinta dos homens entre si e com a natureza. Ela não deveria ser pensada em termos de dominação, mas de uma verdadeira reconciliação entre o que se imaginou por tanto tempo serem antagonistas. De acordo com Adorno e Horkheimer, o sujeito percebe o mundo exterior por meio dos vestígios deixados em seus sentidos e também pelas impressões internas consolidadas previamente. Em qualquer situação, caberá ao indivíduo elaborar espiritualmente uma unidade entre o que ele recebe da esfera objetiva e o que ele projeta tanto em sua consciência como em sua atividade prática. Em um tipo superior de interação social nenhuma das instâncias seria integralmente passiva ou ativa.

O objeto fornece não somente certos dados isolados, mas principalmente estruturas, conceitos e juízos ${ }^{208}$. A tarefa do sujeito é aprofundar pela reflexão crítica tal conjunto de impressões e de normas a fim de operar uma síntese que não reproduza imediatamente aquilo que foi apreendido do exterior, ao mesmo tempo em que não se descola plenamente do que acontece na realidade. Quando o objeto não se impõe de forma soberana e nem o pensamento se enrijece no contato com o seu outro, uma espécie de oposição refletida pode unir os dois polos. Ao reconhecer os disparates da razão ocidental e subverter o sentido da marcha civilizacional, o espírito não seria sacrificado e a opressão pela objetividade social poderia ser superada. Em DE:

O esclarecimento é mais que esclarecimento: natureza que se torna perceptível em sua alienação. No autoconhecimento do espirito como natureza em desunião consigo mesma, a natureza se chama a sim mesma como antigamente, mas não mais imediatamente com seu nome presumido, que significa onipotência, isto é, como "mana”, mas como algo de cego, mutilado. A dominação da natureza, sem o que o espírito não existe, consiste em sucumbir à natureza. Graças à resignação com que se confessa como dominação e se retrata na natureza, o espírito perde a pretensão senhorial que justamente o escraviza à natureza. (...). Todo progresso da civilização tem renovado, ao mesmo tempo, a dominação e a perspectiva de seu abrandamento. Contudo, enquanto a história real se teceu a partir do sofrimento real, que de modo algum diminui proporcionalmente ao crescimento dos meios para sua eliminação, a concretização desta perspectiva depende do conceito. Pois ele é não somente, enquanto ciência, um instrumento que serve para distanciar os homens da natureza, mas é também, enquanto tomada de consciência do próprio pensamento que, sob a forma da ciência, permanece preso à evolução cega da economia, um instrumento que permite medir a distância perpetuadora da injustiça. ${ }^{209}$

\section{O antissemitismo em seus aspectos mágicos e religiosos.}

208 Idem. Ibidem; p. 176.

209 Idem. Ibidem; p. 50. 


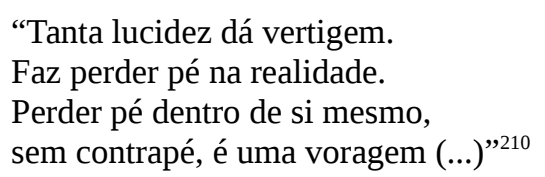

Convém examinar ainda um outro momento crucial no qual Adorno e Horkheimer dialogam com alguns aspectos da sociologia weberiana em DE. Ao perscrutarem as origens e os mecanismos de funcionamento do antissemitismo, os frankfurtianos também lançam mão de certas categorias forjadas no debate com Weber. Embora haja diversas referências a tantos outros pensadores, a relação com o autor de ES mantém-se presente ${ }^{211}$. A apropriação frankfurtiana de tais conceitos reaparece na tentativa de interpretar como se articula uma efetividade social pautada pela reiteração dos princípios vitoriosos na história de nossa civilização, mas que foram radicalizados em um nível inaudito.

As antinomias com as quais a vida coletiva se depara em tempos de capitalismo tardio fazem reviver velhos dilemas. O curioso é que tudo reaparecerá com o sinal trocado. Ao mesmo tempo que os fetiches não serão mais portadores de poderes mágicos, mas conservarão a sua peculiar forma de veneração, a irracionalidade dos regimes nazifascistas é patente, embora estes se valham de métodos racionais para planejar - prática e teoricamente - o seu sistema de morticínio.

Dominar a natureza já era o objetivo último das práticas mágicas mais elementares, ainda que o rigor e a excepcionalidade dos ritos dos feiticeiros impedissem o agir instrumental de se autonomizar. Com alguma dubiedade e certos vacilos, as religiões mundiais, a razão e a ciência moderna incumbiram-se da missão de eliminar a magia fortalecendo um progressivo processo de abstração, atuante desde as primeiras práticas rituais mágicas até os procedimentos científicos atuais. Universalizada pelo sistema produtor de mercadorias, esta forma calculadora de se relacionar

210 Melo Neto, João Cabral. "Diante da folha branca”; p. 556.

211 Até mesmo no que se refere à interpretação de certos fenômenos mágico-religiosos associados ao antissemitismo, Weber não é a única referência. A esse respeito, um importante trabalho que visou reconstruir o debate com os conceitos freudianos é Antissemitismus und Gesellschaftstheorie, de Eva-Maria Ziege. A autora reconhece a necessidade de pensar tal questão também a partir de uma comparação com a sociologia weberiana. Segundo Ziege: “Até mesmo na linguagem - e não apenas nesse nível - Horkheimer e Adorno se aproximam da sociologia da religião de Max Weber. O fato da falta de menção direta a isso seria um interessante tema de pesquisa. É sabido que que ao menos Horkheimer conhecia bem os diversos trabalhos de Wittfogel que tematizavam sobre a relação do marxismo com a teoria weberiana” Ziege, E. Antissemitismus und Gesellschaftstheorie; p. 127. 
libertar a vida coletiva dos ditames de um autômato, as sociedades modernas confundiram a razão com um mecanismo cego e abstrato de dominação da natureza. Diante da insatisfação geral com os descaminhos inerentes a tal arranjo, o grupo religioso que pela primeira vez dotou tal engrenagem de coerência lógica é apontado - de forma ignóbil - como o único culpado pelos infortúnios do presente. Em DE:

A civilização é a vitória da sociedade sobre a natureza, vitória essa que tudo transforma em pura natureza. Os próprios judeus participaram desse processo ao longo dos milênios, com espírito esclarecido e com cinismo. Representantes do mais antigo patriarcado ainda existente, encarnação do monoteísmo, eles transformaram os tabus em máximas civilizatórias, enquanto os outros se encontravam ainda no estágio da magia. Os judeus pareciam ter conseguido aquilo que o cristianismo em vão buscava: destituir a magia de seu poder por meio de sua própria força, que se volta contra si mesma no culto religioso. Mais do que extirpar a assimilação à natureza, o que fizeram foi superá-la conservando-a nos puros deveres do ritual. Desse modo, conservaram dela a memória expiatória, sem recair pelo símbolo na mitologia. É por isso que são considerados pela civilização avançada como atrasados e muito avançados, como semelhantes e diferentes, inteligentes e estúpidos. Eles são inculpados daquilo que foram os primeiros, primeiros burgueses que foram, a romper em seu íntimo: a tendência a se deixar seduzir pelo inferior, a ânsia da animalidade e da terra, do culto das imagens. Porque inventaram o conceito do casher, são perseguidos como porcos. Os anti-semitas se arvoram em executores do Velho Testamento: eles providenciam para que os judeus, já que comeram da árvore do conhecimento, retornem ao pó. $^{212}$

Como índice de sua falsidade, esses conflitos parecem requerer as roupas do passado para

serem novamente expostos. De acordo com Adorno e Horkheimer, o antissemitismo moderno

possuiria uma inextirpável matriz de conteúdo religioso. De certo modo, algumas imagens do

mundo continuam a determinar os trilhos pelos quais a conduta humana vê-se empurrada pela

dinâmica dos interesses no capitalismo tardio ${ }^{213}$. A religião não foi abolida, mas integrada como

212 Adorno, T. \& Horkheimer, M. Dialética do esclarecimento; págs. 173-174.

213 Em “A ética da mercadoria, segundo Karl Marx”, Ricardo Musse salienta a proximidade entre as maneiras pelas quais Marx e Weber concebiam a relação entre certos elementos culturais e a conduta típica das classes e dos indivíduos no capitalismo moderno. Contudo, se Weber realmente utiliza o conceito de "ética religiosa” em um sentido muito próximo à noção de ideologia de Marx, Musse também chama atenção para uma divergência radical entre o pensamento desses autores. Grosso modo, enquanto Weber compreenderia a motivação da ação social como um conflito incessante de valores entre si, Marx identificaria a atuação de um mecanismo - o fetichismo da mercadoria - que, de um lado, oculta relação social constitutiva da produção de mercadorias como se fosse uma fantasmagórica relação entre coisas e, de outro, dota-se de uma aparente objetividade, cuja superação é um desafio tanto teórico quanto prático. Segundo Musse: "Desse modo, ao recusar qualquer tentativa de determinação dos fins, ou melhor, de um exame crítico destes pela reflexão, Weber opõe-se veementemente ao diagnóstico de Marx acerca da origem, natureza e futuro do capitalismo. Em lugar de uma sociedade marcada pela reificação, inerente ao fetichismo da mercadoria, Weber concebe o mundo moderno como uma sociedade pautada pelo processo de racionalização social em diversas esferas com desdobramentos independentes. Essa descrição aproxima-se muito do figurino próprio do liberalismo que descreve o mundo moderno como uma sociedade pluralista. Musse, Ricardo. "A ética da mercadoria, segundo Karl Marx”. “A ética da mercadoria, segundo Karl Marx”. Musse, Ricardo, disponível em: http://blogdaboitempo.com.br/2012/07/06/a-etica-da-mercadoria-segundo-karl-marx/. Em alguma medida, 
patrimônio cultural ${ }^{214}$. Da sua antiga imbricação com elementos racionais restou apenas as suas

formas reificadas. A discussão frankfurtiana com o conceito weberiano de desencantamento do mundo volta à cena para interpretar a contemporânea recaída na barbárie.

Em contraste com o significado assumido por esse longo processo histórico-religioso no

Ocidente, a ideia de um Cristo vivo coloca nossa civilização diante de uma encruzilhada ${ }^{215}$. Ainda que marginalmente, Weber já havia documentado em A ética protestante alguma insatisfação com as convicções teológicas de Calvino - um deus como esse não é digno de respeito, mesmo sob custo de uma condenação inapelável ao inferno ${ }^{216}$.

Além disso, a sociologia weberiana preocupou-se em distinguir a especificidade da redenção religiosa garantida a partir da existência física de um salvador. A sistematização e a racionalização da apropriação e dos usos dos bens de salvação variam conforme o grau de eliminação da contradição entre o habitus religioso cotidiano e o extracotidiano ${ }^{217}$. Seja por desempenhar o papel de intercessor capaz de aplacar a ira de Deus, seja para libertar os homens da influência de

pretendi estabelecer neste item uma discussão semelhante entre a sociologia weberiana e os frankfurtianos.

214 Adorno, T. \& Horkheimer, M. Dialética do esclarecimento; p. 164. A esse respeito, Eva-Maria Ziege chama atenção para a proximidade que essa crítica de Adorno e Horkheimer também tem com o pensamento de Freud. Segundo Ziege: "Interpretada em sua funcionalidade, a religião é um elemento como também qualquer outra forma de figuração ideológica. (...). Judaísmo e cristianismo foram usados como denominadores desse processo, do quais Freud, também um atento crítico da religião, havia anteriormente interpretado em $\mathbf{O}$ futuro de uma ilusão (1927). Cada religião precisa de um ritual de sacrifício, que aos demais poderia parecer como um sacrilégio, mas ao mesmo tempo em que as fortalece são por elas simbolicamente arrefecidos. (...). Por essa razão, o cristianismo se separa dessas origens ritualísticas das religiões por uma espiritualização. O ritual é liberado para a política, e toda violência estatal se legitima como um objeto religioso.” Ziege, Eva-Maria. Antisemitismus und Gesellschaftstheorie; págs. 126-127.

215 Ainda antes de Weber, o cristianismo também fora alvo de especulações filosóficas modernas. É preciso lembrar que Hegel, Nietzsche, o jovem Marx entre outros já haviam se debruçado sobre essa questão. Não há dúvidas de quem tanto Weber quanto Adorno e Horkheimer conheciam profundamente e dialogaram intensamente também com esses autores. Seria bastante oportuno problematizar a perspectiva weberiana e a dos frankfurtianos também em contraste com as desses outros pensadores. Contudo, isso ultrapassaria em muito os limites desta pesquisa. De toda forma, no capítulo "The Problem of Christianity" de From Hegel to Nietzsche, Löwith apresenta uma interessante interpretação das críticas ao cristianismo iniciadas por Hegel, passando pelos jovens-hegelianos e que atingiram o seu clímax com Nietzsche. Enquanto este último é apontado aquele que formula a ruptura mais radical da filosofia com o cristianismo, Hegel seria o autor que pretendeu reconciliá-los. Em uma passagem que expressaria uma grande distancia de Hegel em relação aos frankfurtianos, Löwith afirma a respeito da avaliação do filósofo sobre a religião cristã: "O tema dominante dessa exposição crítica da religião cristão é a questão se é possível restaurar a 'totalidade' da 'vida' que se aliena em si mesma. Hegel considera que a tarefa histórica de Jesus fora a restauração da totalidade interna em oposição à 'positividade' (Gesetztheit) da religião da lei (Gesetzt) dos judeus; isso se realizaria por meio de uma religião do 'amor' que deveria superar a da 'lei'”. Löwith, Karl. From Hegel to Nietzsche; págs. 328-329.

216 Weber, Max. A ética protestante; p. 92.

217 Weber, Max. “Sociologia da religião”; p. 363. 
demônios ou por tantas outras missões ${ }^{218}$, a presença de alguém como Cristo amainaria as rigorosas exigências éticas no trato com o divino. É certo que ele ou outros profetas também revelavam ou confirmavam preceitos religiosos reunidos em doutrinas sistemáticas. Porém, a conduta de vida de seus seguidores se encontraria em uma região indistinta entre a coerção mágica sobre os espíritos e as súplicas religiosas a um deus absoluto.

Em virtude de seu carisma pessoal, o profeta diferencia-se dos sacerdotes por não estar a serviço de uma tradição e por seus poderes não dependerem da legitimidade de um cargo vinculado a uma instituição. Por outro lado, se a pessoalidade do seu dom ou de seu carisma especial o aproxima dos feiticeiros, ele não ministra celebrações mágicas, mas anuncia principalmente mandamentos éticos e ensinamentos doutrinários ${ }^{219}$. Em “Sociologia da religião”:

A religiosidade de fé voltada para a "salvação” das camadas sociais pacificadas, tem certo parentesco, claro que em graus muito diversos, com a mística contemplativa, mais do que com a confiança primitiva do guerreiro no poder imenso de seu deus, predominante na religião de Jeová e no Islã antigo. Pois todo bem de "salvação” como esse, almejado em termos de "redenção", pelo menos tende a tornar-se uma relação "estática” com o divino, uma unio mistica. E quanto mais sistemática é então a elaboração do caráter de convicção prático da fé, tanto mais facilmente podem surgir, como em toda mística, conseqüências diretamente anomísticas. Já as Epístolas de Paulo, bem como certas expressões contraditórias encontradas no legado de Jesus, mostram a grande dificuldade de se estabelecer uma relação inequívoca entre uma autêntica religiosidade de "salvação", baseada na "fé" no sentido de uma relação de confiança, e determinadas exigências éticas. (...). Em regra, a salvação pela fé, quando muito acentuada, não atua facilmente, numa religião cotidiana, no sentido de uma racionalização ética ativa da condução da vida, como pode muito bem ocorrer na pessoa do profeta. Em certas circunstâncias atua diretamente em sentido anti-racional, tanto em questões isoladas quanto de princípio. ${ }^{220}$

Quanto maiores fossem os poderes associados ao profeta ou ao salvador, tanto menores seriam os incentivos ao desenvolvimento de uma ética religiosa sistemática. A zona de indistinção aventada, portanto, não se restringe à relação necessariamente tensa entre a empiria e os conceitos

\footnotetext{
218 Idem. Ibidem; p. 374.
}

219 A esse respeito, segundo Weber: "De resto, o decisivo é a absoluta indiferença em relação ao mundo e seus assuntos. O reino de Deus, um reino de felicidade sem sofrimento e sem culpa sobre a terra está próximo; esta geração não morrerá sem vê-lo; ele virá como o ladrão na noite; na verdade já começa em meio aos homens. Em vez de agarrar-se ao Mamona injusto, é melhor fazer-se de amigo com ele. Pode-se dar a César o que é de César que importam essas coisas? Deve-se rezar a Deus pelo pão de cada dia sem se preocupar com o dia seguinte. A vinda do reino não pode ser acelerada por nenhuma ação humana. Mas é bom preparar-se para ela. E, neste ponto, ainda que a lei não esteja suspensa formalmente, absolutamente tudo da natureza começa a depender da convicção, identificando-se todo o conteúdo da lei e dos profetas com o simples mandamento do amor a Deus e ao próximo e acrescentando-se a sentença, de grande alcance: que se deve reconhecer a espiritualidade genuína por seus frutos, isto é, por suas provas.” Idem. Ibidem; p. 418.

220 Idem. Ibidem; págs. 380-381. 
teóricos, tal como Weber a compreendia pelas regras de composição de seus tipos-ideias. A verdadeira questão é mais essencial. Como se portar ante o filho de deus, que realizou alguns milagres quando vivia entre os homens, mas cujo carisma especialíssimo possui o objetivo de reiterar os preceitos éticos do deus absoluto e criador do universo?

A resposta dos protestantes realiza a única concessão possível por conta da excepcionalidade do caso. Todavia, fossem os princípios racionais os únicos critérios atuantes na composição de dogmas religiosos, tal postura deveria ser compreendida como mais uma divinização da criatura. A existência de deus como homem desencadeia uma postura não-racional com o sagrado. Nem mesmo os apóstolos mais íntimos a Cristo se dirigiam aos céus para cobrar recompensas salvacionistas - e tanto menos por uma vida materialmente mais abonada ou mais prazerosa na Terra. Mas a fé ligada ao seu nome e à sua palavra afirma que move montanhas, e diz perdoar subitamente um dos ladrões crucificados ao seu lado. Em "Sociologia da religião":

Essa atitude interna especificamente anti-racional, própria de uma religiosidade de confiança ilimitada em Deus, que chega às vezes até a uma indiferença acósmica perante considerações práticas de tipo intelectual e leva freqüentemente àquela confiança incondicional na providência de Deus - que imputa a ele, exclusivamente, as conseqüências dos próprios atos, sentidos como algo querido por Deus -, encontra-se tanto no cristianismo quanto no islã e por toda parte em forte contraste com o "saber", particularmente o saber teológico. Isso pode configurar-se como soberba virtuosidade de fé ou, ao contrário, quando evita o perigo dessa presunção divinizadora da criatura, como uma atitude de incondicional entrega religiosa e humildade absorta em Deus, que exige antes de tudo a mortificação do orgulho intelectual. ${ }^{221}$

De acordo com Adorno e Horkheimer, enquanto religião do amor, Cristo suavizara o medo absoluto quanto à salvação das almas, pois essa sua forma humana ressuscitou a promessa messiânica $^{222}$. Se a nova aliança não suprimiu a condição de criatura, ela ao menos livrou a humanidade das piores consequências do pecado original. Embora a ética de vida religiosa triunfante no Ocidente tenha desbancado o poder dos feiticeiros, o sacrifício do espírito que criou a si mesmo e se fez homem reabriu as portas dos céus. Malgrado as desencantadas concepções e práticas religiosas dos protestantes, a soteriologia cristã continha em si um elemento mágico originário.

221 Idem. Ibidem; págs. 379-380.

222 Adorno, T. \& Horkheimer, M. Dialética do esclarecimento; p. 165. 
A interpretação frankfurtiana é eminentemente histórica. Não se trata do desdobramento interno e idealista de um conceito absoluto. A noção de universalidade concebida no Ocidente mantém-se dialeticamente associada a práticas sociais concretas. Em termos religiosos, é como se a concepção mais abstrata da natureza do divino fosse também de uma espécie similar à antiga cerimônia mágica. No lugar de um processo hegemônico de desencantamento do mundo, o que se vê é um tipo peculiar de encantamento propagado pelo mais abstrato dos espíritos.

Quando esteve entre os homens, o deus absoluto e transcendente tornou-se um ente de carne e osso e, ao mesmo tempo, encarnou-se em uma espécie de fetiche. Rompendo nas origens com o judaísmo, o cristianismo já teria latente os problemas atrelados a uma certeza muito convicta de si, mas que não oferece nenhuma prova concreta de sua excepcionalidade. Em algum momento da história, um homem qualquer se diz o portador legítimo dos direitos e das qualidades de um conceito universal. Tocar o corpo de Cristo talvez não suprimisse as falhas da humanidade, e certamente não garantiria uma vida menos atribulada pelas incertezas do cotidiano. Contudo, o mais eminente dos feiticeiros absolutizou certas práticas rituais, determinadas formas de atividade cotidiana e - por ser também espírito - sacralizou um tipo peculiar de racionalidade. Em DE:

\footnotetext{
Mas, as mesmas ideias, que permitem ao cristianismo reabilitar a religião natural ressuscitam a idolatria sob uma forma espiritualizada. Na mesma medida em que o absoluto é aproximado do finito, o finito é absolutizado. Cristo, o espírito que se tornou carne, é o feiticeiro espiritualizado. A auto-reflexão humana no absoluto, a humanização de Deus por Cristo é o proton pseudos. O progresso para além do judaísmo tem por preço a afirmação de que o homem Jesus era Deus. É justamente o aspecto reflexivo do cristianismo, a espiritualização da magia, que está na raiz do mal. Apresenta-se como tendo uma essência espiritual justamente aquilo que, diante do espírito, se revela como tendo uma essência natural. O espírito consiste exatamente no desdobramento da contradição contra semelhante pretensão do finito. Assim, a má consciência tem que recomendar o profeta como símbolo, a prática mágica como transformação. Isso faz do cristianismo uma religião, em certo sentido única: uma ligação intelectual com o intelectualmente suspeito, um domínio cultural particular. ${ }^{223}$
}

Corporificado, o mais imaterial dos espíritos prostra-se diante das coisas de maneira similar aos curandeiros pagãos - não se rompeu com os limites do círculo mitológico. Dominar a natureza descolou-se de sua necessidade material imediata - válida, no melhor dos casos, até o fim do nomadismo - e transubstanciou-se na imagem do ser mais essencial. A figura de Cristo confirma 
que esse tipo de intercâmbio dos homens com a natureza, cujos princípios são pré-históricos, foram radicalizados com as sociedades modernas e conduzidos ao paradoxismo com o nazifascismo, imbrica-se necessariamente a uma faceta mitológica. Esse deus era não só o criador da vida humana e da natureza como era também o mais sublime defensor da injustiça social.

Como foi dito anteriormente, o longo processo de abstração que caracteriza a civilização ocidental tem como pressuposto o aprofundamento das relações de mando e de dominação social. Quando não pura obra do acaso, o que se repete e permite maior previsibilidade para a ação humana é garantido pela voz de comando sobre os outros a fim de conquistar objetivos específicos e particulares. Foi isso que favoreceu a consolidação do culto em torno de determinadas divindades na magia e, posteriormente, elegeu tantos outros deuses monoteístas ao lugar de maior prestígio no panteão. Nesse ponto específico, ainda que Cristo tivesse se oferecido em holocausto para salvar a humanidade, o seu sacrifício não trouxe nada de muito novo. Tal como qualquer entidade pagã, o ser mais essencial era também um objeto material, e o seu conceito de universalidade elide uma figura particular. Em DE:

\begin{abstract}
O cristianismo não é apenas um retrocesso relativamente ao judaísmo. Ao passar da forma henoteísta para a forma universal, seu deus ainda não despiu inteiramente os traços do demônio natural. O terror que tem origem no passado pré-animista passa da natureza para o conceito do eu absoluto que submete inteiramente a natureza como seu criador e dominador. Apesar de todo seu indescritível poderio e magnificência, que essa alienação lhe confere, ele é alcançável pelo pensamento, que se torna universal justamente pela relação com um ser supremo e transcendente. Deus enquanto espírito opõe-se à natureza como o outro princípio, que não garante simplesmente seu ciclo cego, como todos os deuses míticos, mas pode nos liberar desse ciclo. Mas ao mesmo tempo, a abstração e a distância desse deus reforçou o terror do incomensurável, e esse verbo inflexível: $E u$ sou, que nada tolera ao seu lado, supera com sua inescapável violência a sentença mais cega (e, por isso mesmo, mais ambígua também) do destino anônimo. ${ }^{224}$
\end{abstract}

A novidade é de um jaez distinto. Como nos ensina Beckett, o outro dos ladrões perdeu-se mesmo tendo pecado tanto quanto o redimido e estando igualmente tão próximo de Cristo. Por princípio, a salvação pela fé é um embuste. O elemento preanimista originário do cristianismo não possuiu poderes mágicos - ele apenas reaviva a adoração fetichista. Vive-se da esperança de que o mais sublime objeto de reverência religiosa se compadeça de nossos sofrimentos e reavalie as 
nossas condenações eternas. Ele também sofreu como os homens e teve uma morte humana. Entretanto, o caminho a ser seguido não se altera e a recompensa desejada - e que será negada - só se daria no pós-túmulo. Suas recomendações não se restringiam mais aos contornos do círculo mágico, e uma ética sistemática da conduta subjetiva já estava em gestação. A estereotipia dos gestos e das práticas descola-se da concretude e da extracotidianidade próprias à interação com objetos mágicos, apoderando-se da integralidade da vida dos indivíduos.

Com a modernidade tardia, a Terra permanece desencantada. O mundo foi transformado em um inferno, e não há meios mágicos para contornar os seus disparates. O famigerado sacrifício do intelecto pode ser atraente para quem o realiza com a mais nobre das intenções. Ademais, ele próprio não é assim tão condenável, pois representa um protesto - embora silencioso e inócuo - à equivocidade de nossa razão. O seu resultado, porém, é o mesmo do da aurora das sociedades capitalistas. Ainda que a ingenuidade de um fiel seja moralmente superior em relação à aguçada consciência dos representantes do poder, a impotência em transformar o destino intramundano por meios mágico-religiosos é igual entre os feiticeiros e o seu séquito, ou entre os sacerdotes e os seus grupos de leigos. Por ser um ritual e pelo tipo de relação que estabelece com os seus objetos, tampouco a ciência foi capaz de mudar o curso das coisas.

O que se venerou desde o princípio foi a dominação da natureza. Coberta de elogios descabidos, a relação entre dominantes e dominados sobrevive aos distintos ordenamentos sociais. Mesmo as mais elaboradas simbolizações religiosas atribuem de forma falsa um significado para o mundo. O apelo ao que sobrou de preanimismo em uma religião tão abstrata e desencantada revela a incontornável parcialidade de uma aposta feita em tais termos. Em DE:

Essa dotação de sentido é enganosa porque a igreja vive, é verdade, do fato de que os homens vêem o caminho para a salvação na obediência à sua doutrina (não importa se ela exige obras, como a versão católica, ou a fé, como a versão protestante), mas não pode garantir o objetivo. O fato de que a promessa espiritual da salvação não cria nenhuma obrigação - esse aspecto o judeu e negativo na doutrina cristã - é tacitamente rejeitado pelo crente ingênuo; o cristianismo, o supranaturalismo, torna-se para ele um ritual mágico, uma religião natural. Ele só crê esquecendo sua própria fé. Ele se persuade do saber e da certeza como os astrólogos e os espíritas, mas isso não é necessariamente o pior em face da teologia espiritualizada. A velhinha italiana que, em sua piedosa simplicidade, consagra uma vela a San Gennaro em favor do neto que partiu para a guerra, pode estar mais 
próxima da verdade do que os papas e os bispos que, imunes à idolatria, abençoam as armas contra as quais San Gennaro é impotente. ${ }^{225}$

O judaísmo tornou-se uma espécie de má consciência crítica do processo vitorioso, pois manteve-se fiel ao princípio desencantado de não nomear o único ser sagrado. Quem não reconhecer em Cristo a existência física do deus monoteísta e criador do universo não pode estar entre os eleitos. Se eles não rogam por esse ser especial nos inevitáveis momentos de infelicidade é porque são piores do que o diabo. O ódio antissemita encontra uma justificativa religiosa para tentar se convencer da razoabilidade de seus disparates.

De antemão, sabe-se que a promessa de salvação religiosa à qual o antissemita submete-se é falsa e não será cumprida - por ser de uma natureza tão transcendente, mesmo que o fosse, ela não alteraria nada das condições de sua infelicidade terrena. Ao manter uma postura vigilante a respeito de seus hábitos ético-religiosos, os judeus suscitam certos tipos de reação. A mais obtusa os acusa não só de terem sido incapazes de evitar, mas de serem os responsáveis diretos pela morte de Cristo.

Ainda que recolhida dentro de sinagogas, a comunidade judaica torna-se alvo de uma inveja nada silenciosa. A reprodução das práticas rituais dos judeus soa de modo dissonante para os seus perseguidores. Talvez seja uma provocação de alguém que se julga o mais astucioso. A articulação interna do raciocínio antissemita é primária. Quando os seus portadores procuram verbalizar suas insatisfações, eles esbravejam. Certamente, os motivos religiosos não são os únicos que foram manipulados para legitimar os desatinos dos antissemitas. Todavia, por estar confundido pelas palavras e por seus significados, ele culpa os judeus pelo desfortúnio de ter sido logrado. Em DE:

Mas os outros, que recalcavam esse pressentimento e, com má consciência, procuravam se persuadir do cristianismo como uma posse segura, tinham que buscar a confirmação de sua salvação eterna na desgraça eterna daqueles que não faziam o turvo sacrifício da razão. Eis aí a origem religiosa do anti-semitismo. Os adeptos da religião do Pai são odiados pelos adeptos da religião do Filho porque acham que sabem de tudo. É a hostilidade do espírito própria ao espírito que se endurece na presunção de ser a salvação. O que escandaliza os inimigos cristãos dos judeus é a verdade que resiste ao mal sem racionalizá-lo e retém a Idéia da beatitude imerecida contra o curso do mundo e a ordem da salvação, que deveriam pretensamente realizá-la. O anti-semitismo deve confirmar a legitimidade do ritual da fé e da história, executando-o naqueles que o negam. ${ }^{226}$

225 Idem. Ibidem; p. 167. 226 Idem. Ibidem; p. 167. 
Esse tipo de consciência religiosa subverte a ordem das coisas. O conteúdo dessas ideias pesa como chumbo sobre a cabeça dos antissemitas contemporâneos. Imaginam-se como dotados de uma legítima vocação, cujo propósito é uma mentira manifesta. Se os puritanos minoravam as suas dúvidas sobre a salvação das almas por meio de uma regulamentação ascética e desencantada de suas vidas, nem essa alternativa parece estar mais disponível. Como qualquer homem moderno, os antissemitas não conseguem acreditar realmente em poderes mágicos e, ainda pior, sabem que a sua típica conduta de vida não os levará ao paraíso. É certo que há muito não se teme mais pela perdição das almas. Porém, para suportar as incertezas do dia a dia, as suas superstições materializam-se por meio de uma manipulação da antiga mímese da magia. Respeitando uma doutrina ideológica repleta de furos e se adornando com fetiches que não aliviam as suas angústias, a veneração professada torna-se compulsiva.

Os antissemitas frequentam cerimônias especiais, admiram o poder não somente simbólico de uniformes e de totens, cultuam lideranças que se apresentam estigmatizando algo que os faria sentir medo e, em muitos casos, participam ativamente do genocídio de povos e de etnias. Eles não parecem seduzidos por nenhuma promessa de redenção transcendente. Mas o ódio que sentem, que antes lhes parecia um difuso sentimento de mal-estar, pode ser descarregado em um alvo preciso. Tal como na magia, o objetivo a ser atingido volta a ser muito palpável e concreto. Que a fúria contra o judeu não traga benefícios econômicos ou vantagens pessoais mais imediatas e somente alimente a própria sede de destruição inerente a uma falsa ordem social, apenas deixa mais marcado a insofismável irracionalidade inerente ao conjunto. Em DE:

O sentido das fórmulas fascistas, da disciplina ritual, do uniformes e de todo o aparato pretensamente irracional é possibilitar o comportamento mimético. Os símbolos engenhosamente arquitetados, próprios a todo movimento contra-revolucionário, as caveiras e mascaradas, o bárbaro rufar dos tambores, a monótoma repetição de palavras e gestos são outras tantas imitações organizadas de práticas mágicas, a mimese da mimese. O Führer, com sua cara de canastrão e o carisma da histeria orquestrada, puxa a roda. Sua representação realiza substitutivamente e em imagem o que é vedado a todos os demais na realidade. Hitler pode gesticular como um palhaço; Mussolini pode arriscar notas erradas como um tenor de província; Goebbels pode falar com a fluência do representante comercial judeu que ele exorta a assassinar; Coughlin pode pregar com a fé do Salvador, cuja crucifixão ele descreve a fim de que se volte sempre a derramar o sangue. O fascismo também é totalitário na medida em que se esforça por colocar diretamente a serviço da 
dominação a própria rebelião da natureza reprimida contra essa dominação. ${ }^{227}$

Apesar de bárbara, a situação é fundamentalmente moderna. Não há diferenças qualitativas em relação à maneira pela qual os homens interagem com os seus fetiches no capitalismo moderno. Na verdade, partilha-se a mesma forma e a mesma essência. Caso haja algumas distinções, elas explicam-se pela maior alienação dos sujeitos e dos objetos, conquistada ao longo de nossa civilização e acelerada com o fim do capitalismo liberal. Os princípios hegemônicos de sempre não são mais constrangidos. Adotando-os quase como instintos, alguns homens modernos transubstanciam-se em antissemitas.

Pois, se a mercadoria é portadora de um segredo que a faz ser vista como sujeita a leis naturais e não como produto do trabalho humano, o indivíduo moderno não deixa de reconhecer um caráter natural em certos objetos, em determinadas formas de existência e até em relações sociais. O mesmo mecanismo atua nos dois casos independente da consciência dos sujeitos envolvidos. De modo muito similar, o antissemita enxerga nas diferenças culturais fundamentos biológicos, na apropriação do trabalho alheio uma necessidade objetiva e na invasão de outros países, o destino de um povo. Há bons motivos para se suspeitar na sinceridade de tal crença. Os seus objetivos são abertamente irracionais, e os argumentos mais razoáveis não são sequer levados em conta. De qualquer modo, eles agem como se acreditassem. Em DE:

A arianização da propriedade judáica (que, aliás, na maioria dos casos beneficiou as classes superiores) não trouxe para as massas do III Reich, vantagens muito maiores do que, para os cossacos, o miserável espólio que estes arrastavam dos guetos saqueados. A vantagem real era uma ideologia parcialmente devassada. O fato de que a demonstração de sua inutilidade econômica antes aumenta do que modera a força de atração da panacéia racista (völkisch) indica sua verdadeira natureza: ele não auxilia os homens, mas sua ânsia de destruição. O verdadeiro ganho com que conta o "camarada da etnia” (Volksgenosse) é a ratificação coletiva de sua fúria. Quanto menores são as vantagens, mais obstinadamente e contra seu próprio discernimento ele se aferra ao movimento. O anti-semitismo mostrou-se imune ao argumento da falta de rentabilidade. Para o povo, ele é um luxo. ${ }^{228}$

Diante de um oponente imaginário, os antissemitas refugiam-se na segurança da estereotipia ritual. O mundo objetivo da ciência moderna já não era mais portador de algum valor imanente e o agir instrumental também não reconhecia qualquer interdito. Ninguém mais teme perturbar os sonos 
de entidades sobrenaturais, embora o que restou de natural nos homens ainda apareça como ameaça. Herdeiro de tal situação, os antissemitas aprofundam mais a distância do sujeito em relação ao objeto, tornado este último finalmente em uma presa. Os seus rituais revelam o verdadeiro significado da dominação desbragada. No limite, a sua irracionalidade parece querer nos convencer de que a razão nunca ultrapassou uma estreita compreensão de si mesma. Impacientando-se ante qualquer ponderação, o juízo antissemita é apressado. Já não se trata somente da postura que enxerga o seu outro pelos critérios de identidade formal, tidos ilegitimamente como os da própria razão. Por suas lentes oblíquas e desfocadas, o antissemitismo avança com violência até deturpar todas as formas de existência - e , ensandecido, não se constrange nem mesmo ante a sepultura de seus inimigos. Em DE:

\begin{abstract}
O mecanismo que a ordem totalitária põe a seu serviço é tão antigo quanto a civilização. Os mesmos impulsos sexuais que a raça humana reprimiu souberam se conservar e se impor num sistema diabólico, tanto dentro dos indivíduos, quanto dos povos, na metamorfose imaginária do mundo ambiente. O indivíduo obcecado pelo desejo de matar sempre viu na vítima o perseguidor que o forçava a uma desesperada e legítima defesa, e os mais poderosos impérios sempre consideraram o vizinho mais fraco como uma ameaça insuportável, antes de cair sobre eles. A racionalização era uma finta e, ao mesmo tempo, algo de compulsivo. Quem é escolhido para inimigo é percebido como inimigo. O distúrbio está na incapacidade de o sujeito discernir no material projetado entre o que provém dele e o que é alheio. ${ }^{229}$
\end{abstract}

Uma fúria arcaica levanta-se ante a mera suspeita da não adoção de seus princípios. A moderna figura estereotipada do judeu parece também ter sido forjada sob medida. Quem abre mão do domínio político para garantir suas posses financeiras professa somente propósitos comezinhos. Certamente, eles devem estar conspirando algo, pois ninguém toleraria um destino tão incerto. Ademais, ao permanecerem por tanto tempo associados à esfera de circulação de mercadorias, os judeus tornaram-se sinônimo da opressão econômica capitalista. Camuflada na produção e no uso da força de trabalho, a dominação social cobra o seu preço mais alto nas trocas comerciais cotidianas. A culpa pelo reduzido poder de compra dos salários é transferida imediatamente para os judeus. Não fossem tantos outros grupos os acossados, a afirmação de que os papéis de vítimas e de perseguidores seriam intercambiáveis soa quase contraditória. A eleição do judeu como objeto de 229 Idem. Ibidem; p. 174-175. 
ódio poderia ser imaginada como a possibilidade formalmente mais coerente.

A solução mais equivocada para os conflitos e as contradições objetivas do capitalismo tardio repisa as estratégias de sempre. A fantasiosa imagem do judeu é o pressuposto para a sua aniquilação real. A abstração é a mais radical, posto que é elaborada de maneira completamente desprendida da realidade. Dentro do ritual de extermínio antissemita, a racionalidade que tão bem particulariza o Ocidente moderno revela estar na origem do sofrimento ${ }^{230}$. Em DE:

Os judeus são hoje o grupo que, tanto prática quanto teoricamente, atraem sobre si a vontade de destruição que uma falsa ordem social gerou dentro de si mesma. Eles são estigmatizados pelo mal absoluto como o mal absoluto. Assim, eles são de fato o povo eleito. Ao mesmo tempo que se afirma que, economicamente, a dominação não seria mais necessária, os judeus são designados como o objeto absoluto de uma dominação pura e simples. Aos trabalhadores, que afinal são os visados, ninguém o diz na cara (e com razão); os negros, é preciso conservá-los em seu lugar; mas, quanto aos judeus, a terra precisa ser purificada deles, e o grito que conclama a exterminá-los como insetos encontra eco no coração de todos os fascistas em potencial de todos os países. Os racistas (die Völkschein) exprimem sua própria essência na imagem que projetam dos judeus. Sua ânsia é posse exclusiva, a apropriação, o poder sem limites, a qualquer preço. O judeu, sobre o qual descarregam a própria culpa e que escarnecem como dominador, eles o pregam na cruz, repetindo interminavelmente o sacrifício em cuja eficácia não conseguem mais acreditar. ${ }^{231}$

Quando a sua postura prescinde de argumentos religiosos, o antissemita encontra-se com uma paranoia secular, mas ainda comporta-se como se estivesse em um ritual pré-histórico. Ele mobiliza os maiores disparates do pensamento para realizar o mais sórdidos dos objetivos. Manoseando uma espécie de linguagem quase científica, a sua forma de raciocínio coage os saberes modernos a justificar uma consciência e uma conduta de vida evidentemente doentias. Coberto de proselitismo, este corolário privilegiou aquilo que existia de mais arrepiante junto à civilização ocidental. Ignorando a inevitável contradição entre sujeito e objeto, projeta-se na realidade apenas a nulidade de sua interioridade subjetiva e a monotonia do mundo objetivo no qual ele fora educado. Embora o judeu não corresponda à sua indecorosa caricatura e nem as ordens econômica, social e política necessitem se organizar de uma maneira tão mesquinha, nada abala as suas convicções. Em

\section{DE:}

Eles saem a pilhar e constroem uma ideologia grandiosa para isso, e fala disparatadamente da salvação da família, da pátria, da humanidade. Mas como continuam a ser os logrados - o que já pressentiam secretamente -, seu mísero motivo, o roubo, ao qual

230 Idem. Ibidem; p. 159.

231 Idem. Ibidem; págs. 157-158. 
devia servir a racionalização, desaparece inteiramente, e esta ideologia torna-se involuntariamente sincera. A obscura pulsão, com que desde o início tinham maior afinidade do que com a razão, toma conta deles totalmente. A ilha racional é inundada e os desesperados aparecem agora unicamente como os defensores da verdade, os renovadores da terra, que têm que reformar até o seu último recanto. Tudo o que vive converte-se em material de seu dever atroz, que nenhuma inclinação mais vem prejudicar. A ação torna-se realmente um fim em si e autônomo, ela encobre sua própria falta de finalidade. $\mathrm{O}$ anti-semitismo conclama sempre a ir até o fim do trabalho. Entre o anti-semitismo e a totalidade havia desde o início a mais íntima conexão. A cegueira alcança tudo, porque nada compreende. ${ }^{232}$

Assim, o esclarecimento subjugou a mitologia e a magia como simples superstições, e o antissemitismo demostra que a supersticiosa era, na verdade, a própria razão ocidental. Essa forma regressiva da racionalidade assume o controle das sociedades e a humanidade reencontra-se com a barbárie da qual ela nunca conseguiu escapar. Puramente automatizada, a dominação da natureza traz à tona os seus limites internos ${ }^{233}$. Deparar-se com eles às claras não era um desenlace lógico necessário. Porém, na linha de continuidade da tendência hegemônica que forjou uma sociedade conforme suas aspirações, a recaída na barbárie não pode ser puro produto do acaso. A forma de interação dos homens com a natureza intensificou os princípios que vigoram desde o início e desbancou a possibilidade de todo tipo alternativo imaginável. Presa às incoerências lógicas ligadas a esse destino, o ápice da razão ocidental foi ter sido instrumentalizada para o planejamento de campos de concentração.

Deixada por sua conta e risco, a razão poderia defender-se alegando a neutralidade de seus meios. De acordo com Adorno e Horkheimer, a técnica não é em si a origem do mal, mas sim o seu enredamento com certas práticas sociais e com determinadas representações simbólicas. O ímpeto bárbaro do nazifascismo pode ser controlado, mesmo que não haja uma mudança qualitativa de

232 Idem. Ibidem; págs. 160-161.

233 A esse respeito, segundo Gabriel Cohn: "Ao discutir o anti-semitismo, Adorno e Horkheimer (aqui cabe especialmente a inversão da ordem editorial dos autores, pois o texto exibe em passagens decisivas o inconfundível estilo adorniano) explicitam melhor o que vem a ser esse limite. E o fazem ao expor o que seria na fase contemporânea a contrapartida, no processo da razão esclarecida, à grande oposição que mostraram ao construir o conceito de Esclarecimento: aquela entre razão e mito, que tem como substrato material o projeto de completa dominação da natureza. Trata-se nesse ponto de expor uma outra dialética, não a que envolve a razão e a sua sombra mas a que envolve a produção da sua sombra pela própria razão: a dialética da razão e do ofuscamento. Pois nesse texto já ocupa posição central um dos grandes temas de Adorno, que se traduziria na sua concepção de um 'nexo universal de ofuscamento': o de que a razão privada da sua capacidade reflexiva, deixada a solta na exacerbação do seu impulso dominador alimentado pela sempre presente ameaça da regressão mítica, gera luzes, sim, mas que ofuscam e levam à cegueira." Cohn, Gabriel. "Esclarecimento e ofuscação: Adorno \& Horkheimer hoje”; p. 7. 


\section{suprime o fundamento mais essencial que conduziu àquele sombrio desenlace ${ }^{234}$. A verdadeira}

reivindicação emancipatória assenta-se em outras bases. Que os homens se relacionem com a

natureza para além da perspectiva de sua dominação, deve ser tanto um objetivo a ser realizado na efetividade social como o padrão para a crítica à sociedade. Em DE:

A sociedade é um prolongamento da natureza ameaçadora enquanto compulsão duradoura e organizada que, reproduzindo-se no indivíduo como uma autoconservação consequente, repercute sobre a natureza enquanto dominação social da natureza. A ciência é repetição, aprimorada como regularidade observada e conservada em esteriótipos. A fórmula matemática é uma regressão conscientemente manipulada, como já o era o rito mágico; é a mais sublime modalidade do mimetismo. A técnica efetua a adaptação ao inanimado, não mais como a magia, através da imitação corporal da natureza externa, mas através da automatização dos processos espirituais, isto é, através da sua transformação em processos cegos. Com seu triunfo, as manifestações humanas tornam-se ao mesmo tempo controláveis e compulsivas. Da assimilação à natureza resta apenas o enrijecimento contra ela. Hoje, a coloração destinada a proteger e a repelir é a dominação cega da natureza, que é idêntica à funcionalidade prognosticadora. ${ }^{235}$

234 A esse respeito, segundo Adorno e Horkheimer: “Mas, hoje, é só isto que resta. Continua-se a escolher, mas apenas entre totalidades. A psicologia anti-semita foi, em grande parte, substituída por um simples 'sim' dado ao ticket fascista, ao inventário de slogans da grande indústria militante. Do mesmo modo que a máquina do partido de massas impõe aos eleitores, com as listas de candidatos, os nomes de pessoas de quem não têm o menor conhecimento e que só podem eleger em bloco, assim também os pontos ideológicos centrais estão codificados em poucas listas. É preciso optar em bloco por uma delas, se não se quiser ter a impressão de que a opinião pessoal é tão inócua como os votos dispersos em comparação com as enormes cifras estatísticas. (...). A experiência é substituída pelo clichê e a imaginação ativa na experiência pela recepção ávida. Sob pena de uma rápida ruína, os membros de cada camada social devem engolir sua dose de orientações. Eles têm que se orientar tanto no sentido de se informarem sobre os modelos de aviões mais recentes, quanto no sentido da adesão a uma das instâncias dadas do poder.” Adorno, T. \& Horkheimer, M. Dialética do esclarecimento; p. 187.

235 Ibidem; p. 169. 


\section{Apêndice. Os descalabros da razão. Weber e a Eclipse da razão.}

Tal como explicitado já no prefácio de DE, Adorno e Horkheimer assumiam a tarefa de investigar os fundamentos da coetânea recaída das sociedades modernas em uma nova espécie de barbárie ${ }^{236}$. Em seu conjunto de conferências de conferências proferidas na Universidade de Columbia, em fevereiro de 1944, Horkheimer também ambiciona um desafio de alto nível. Na verdade, Eclipse a razão pode ser interpretado como uma tentativa de apresentar as principais teses presentes em DE, mas com a coloração pessoal do autor ${ }^{237}$.

Nesse novo contexto sócio-histórico, as tétricas projeções já observáveis na década de 1930 por Horkheimer se realizaram por meio de violência inimaginável nos anos subsequentes. Como se a selvageria abandonasse as sombras e assumisse o controle do conjunto das sociedades capitalistas, o decurso histórico embaralhou a plausabilidade das promessas utópicas trazidas com as sociedades modernas. A dialética que não se quer metafísica e tampouco dogmática não abre mão de fazer frente às exigências de seu tempo. Já não se trata apenas de um embate travado a fim de salvaguardar a humanidade do poder de instituições e de práticas sociais retrógradas encrustadas nas sociedades modernas. Em face da cegueira causada por aquilo que deveria iluminar, o diagnóstico de que tais tendências somente impediriam a realização de projetos emancipatórios se mostra insuficiente. A barbárie é promovida abertamente e pulsa como se brotasse do seio da vida social.

É certo que o tenebroso desenlace não encerrou definitivamente os clamores por um ordenamento novo e humano das relações sociais de produção. Antes o contrário, eles se tornaram mais prementes. A fria razão burguesa, porém, parece congelar as rotas de fuga e a obtusa realidade ameaça se perpetuar. Reorientar algumas premissas, refazer certos julgamentos e formular uma crítica ainda mais radical ao capitalismo se tornou matéria urgente ${ }^{238}$.

236 Adorno, T. \& Horkheimer, M. Dialética do esclarecimento; p. 11.

237 Wiggershaus, Rolf. A escola de Frankfurt; p. 374.

238 Pode-se mesmo afirmar que tal preocupação atravessa, em geral, todas as fases e períodos da teoria crítica. A esse 
Assim, antes de encher de esperanças, a vitória na segunda guerra mundial faz paradoxalmente renascer sentimentos de impotência e de desalento. Imiscuídos profundamente ao próprio conceito de racionalidade moderna, esses afetos cristalizam os nefastos desdobramentos de uma forma de organização social que compreende o progresso de forma bastante distante do que deveria significar - a realização plena das potencialidades humanas. Ao se desfiliar da longa tradição do pensamento de fundamentar racionalmente os modos de conduta e os critérios de convivência entre os homens, a ciência moderna sela o seu destino e o da própria humanidade. Transformada em um simples método, a atividade intelectual faz com que a razão se encontre à deriva de turbulências e de regressões.

Avaliada por seus pretensos efeitos utilitários, ela perdeu sua relativa autonomia, passando a partilhar dos mesmos desenganos de todos os demais produtos do trabalho humano. Em uma sociedade na qual o desenvolvimento tecnológico poderia livrar completamente os indivíduos de carências materiais, a consequência mais abjeta desta forma da razão não fora ter postergado indefinidamente a realização do que antes parecia ser tecnicamente impossível. O que já era em si intolerável anima-se por um espírito ainda mais indecoroso. A razão instrumentalizada auxilia a por em marcha o absurdo processo de desumanização. Em Eclipse da razão:

No momento em que se escrevem estas palavras, os povos das nações democráticas vêem-se confrontados com o problema de completar a vitória obtida pelas armas. Devem elaborar e pôr em prática os princípios de humanidade em nome dos quais foram feitos os sacrifícios da guerra. As presentes potencialidades de realização social ultrapassaram as expectativas de todos os filósofos e estadistas que jamais esboçaram, em programas utópicos, a idéia de uma sociedade verdadeiramente humana. E apesar disso prevalece um sentimento geral de temor e desilusão. As esperanças da espécie humana pareacem hoje mais distantes de serem realizadas do que mesmo nas épocas ainda tateantes em que primeiro foram formuladas pelos humanistas. Parece que enquanto o conhecimento técnico expande o horizonte da atividade e do pensamento humanos, a autonomia do homem enquanto indivíduo, a sua capacidade de opor resistência ao crescente mecanismo de manipulação de massas, o seu poder de imaginação e o seu juízo independente sofreram aparentemente uma redução. O avanço de recursos técnicos de informação se acompanha de um processo de desumanização. ${ }^{239}$

respeito, como bem apontou Alfons Söllner: “A teoria crítica da Escola de Frankfurt compreendia-se como uma ciência histórica em duplo sentido. Por um lado, ela apreende os objetos analisados como historicamente condicionados, ou seja, revela seu caráter transitório, sua gênese, suas transformações e suas perspectivas de desenvolvimento. Por outro, compreende-se a si mesma como a expressão de uma determinada situação histórica, como a reflexão a respeito de experiências contingentes que, como partes constitutivas de sua auto-compreensão, embrenham-se na formação da teoria e da pesquisa.” Söllner, Alfons. Geschichte und Herrschaft; p. 195.

239 Horkheimer, Max. Eclipse da razão; p. 7. 
Mais uma vez, encaminhar essas problematizações por intermédio de um contraponto com a sociologia weberiana parece ser promissor ${ }^{240}$. Em larga medida, o diagnóstico contido nas páginas de Eclipse da razão não se distingue em essência do elaborado em conjunto com Adorno - o contraste mais gritante se dá, claramente, com relação às reflexões de Horkheimer na década de 1930. Tal como em DE, a instrumentalização da razão e a crítica à dominação da natureza são também os principais alvos de Horkheimer.

Porém, o diálogo com Weber se efetiva por outros caminhos. Se em DE os dois autores pretenderam investigar os mecanismos mais elementares da civilização ocidental também por meio de uma leitura da sociologia weberiana, Horkheimer concentra-se na interpretação do processo de dissolução dos aspectos objetivos da razão nesse seu outro diálogo com o autor de ES. Segundo Horkheimer:

\begin{abstract}
A diferença entre esta conotação de razão e a concepção objetivista se assemelha, em certo grau, à diferença entre racionalidade funcional e substancial, tal como essas palavras são utilizadas na escola de Max Weber. O próprio Max Weber, contudo aderiu de modo tão definitivo à tendência subjetivista que não concebia qualquer racionalidade - nem mesmo uma racionalidade "substancial" - pela qual o homem pudesse discriminar um fim de outro. Se nossos impulsos, intenções e, finalmente, as nossas decisões últimas, devem ser a priori irracionais, a razão substancial se torna apenas uma agência de correlação e é pois, em si mesma, essencialmente "funcional”. Embora as descrições do próprio Weber e dos seus seguidores da burocratização e monopolização do conhecimento tenham iluminado muitos dos aspectos sociais de transição da razão objetiva para a razão subjetiva (...), o pessimismo de Max Weber em relação à possibilidade de compreensão e ação racional, tal como está expresso em sua filosofia (...), é, em si mesmo, degrau básico na renúncia da filosofia da ciência às suas aspirações de definirem o objetivo final do homem. ${ }^{241}$
\end{abstract}

Tal como compreendida por Weber, a formalização da razão atingira seu ápice no capitalismo tardio. Diante da especificidade desse momento histórico enfrentado por Horkheimer, a crítica é impelida a reexaminar - desde dentro e mais a fundo - a racionalidade subjacente à moderna sociedade industrial. Em seu conceito hegemônico, compartilhado por correntes no meio

240 A esse respeito, de acordo com Tarr: “A distinção de Horkheimer entre razão objetiva e substantiva é, de maneira geral, equivalente às entre a racionalidade formal e substantiva de Weber. Para Weber, racionalidade formal significa calculabilidade, eficiência e impessoalidade, isto é, a redução da racionalidade ao seu lado formalmente instrumental. Ele a define em consideração à ação econômica. (...). Por outro lado, o equivalente à razão objetiva de Horkheimer é a 'racionalidade substantiva' de Weber, um 'conceito que tem muitos significados. É como toda análise substantiva sob o seguinte aspecto: não se satisfaz com o fato puramente formal que a mensuração da ação é baseada no cálculo racional com os 'meios mais apropriados tecnicamente', mas envolve outros critérios de fins últimos, como éticos, políticos e assim por diante.” Tarr, Zoltán. The Frankfurt School; p. 86.

241 Horkheimer, Max. Eclipse da razão; p. 12. 
universitário e por homens comuns, ela representa algo mais do que somente uma insossa modéstia na esfera do conhecimento. Ao se imaginar como um mero mecanismo abstrato de classificação, de inferências e de deduções de fenômenos, essa concepção trouxe consigo desdobramentos práticos e teóricos de longo alcance. A total prevalência da razão subjetiva se tornou presa fácil para a crueldade reinante.

Divorciada da razão objetiva nos últimos tempos, esta sua versão subjetiva se deixa definir como um simples instrumento de coordenação. As possibilidade de obtenção de lucro ou de outras vantagens particulares são os seus únicos propósitos. Alheia a elaborações que pudessem formular um objetivo em si mesmo racional, a atual crise da razão se expressa em sua inapetência em avaliar os ideais ou os princípios que norteiam as ações e as crenças dos homens. Se durante largo período de sua história, a filosofia se sentiu responsável pela elaboração ou pela revelação da verdade, os seus herdeiros erigiram um interdito em torno desta palavra. Longe de compreender a razão como um princípio inerente da realidade, essa racionalização meramente formal parece se adequar integralmente aos limites de uma faculdade subjetiva da mente. Segundo Horkheimer:

\begin{abstract}
A crise atual da razão consiste basicamente no fato de que até certo ponto o pensamento ou se tornou incapaz de conceber tal objetividade em si ou começou a negá-la como uma ilusão. Esse processo ampliou-se gradativamente até incluir o conteúdo objetivo de todo conceito racional. No fim, nenhuma realidade particular pode ser vista como racional per se; todos os conceitos básicos, esvaziados de seu conteúdo, vêm a ser apenas invólucros formais. Na medida em que é subjetivada, a razão se torna também formalizada. ${ }^{242}$
\end{abstract}

Os personagens talvez sejam os mesmos de outrora, mas o novo enredo se estrutura com um acréscimo inaceitável de brutalidade. A principal pergunta a ser respondida não seria mais o que deve ser feito para se evitar a degradação das sociedades na vilania da barbárie. Conquanto a bestialidade explícita dos regimes nazifascistas tenha sido refreada após a segunda grande guerra, a vida social dá impressão de ter não conseguido suplantar verdadeiramente o baixo patamar civilizatório desses tempos sombrios. O que orienta a crítica do frankfurtiano é a latente possibilidade de recaída ${ }^{243}$. A fim de evitar o sórdido retorno da selvageria, a razão subjetiva não 242 Horkheimer, Max. Eclipse da razão; p. 13.

243 A esse respeito, ao se posicionar contrariamente às leituras e às interpretações que visam estabelecer um corte radical entre a produção de Horkheimer dos primeiros anos da década de 1930 até os seus últimos trabalhos, 
oferece qualquer resistência.

Valores como os de igualdade, de justiça ou mesmo de democracia já não são mais matéria de qualquer sanção racional. Efetivamente, para essa forma de razão não lhe falta apenas o desejo, mas também as ferramentas conceituais necessárias. Dentro do quadro da ciência moderna não há possibilidade de distinção objetiva. A realização desses ou de inúmeros outros valores fica exclusivamente a cargo da dinâmica dos conflitos de interesses e da força política das variadas classes sociais. É certo que, para Horkheimer, as sociedades nunca chegaram a ser governadas realmente pela razão. Porém, o que se vê é o esmorecimento em altíssima potência da capacidade de se fazer frente às irracionalidades das sociedades modernas ${ }^{244}$. Mais do que se eximir diante da ascensão de poderosos grupos econômicos, cujos interesses estão atrelados à reprodução ampliada de iniquidades e à manutenção e ao aprofundamento de diferenças de classe, a razão formalizada desempenha ela mesma um papel ativo nesses descalabros.

Embora o problema não seja a técnica enquanto tal, mas o contexto sócio-histórico no qual está inserida, por seu intermédio pavimentou-se a via expressa que conduz ao desespero e à prostração ${ }^{245}$. Uma sociedade que se regojiza ao transformar o mundo e todas as relações sociais segundo o reificado modelo de uma grande fábrica moderna parece concluir seus disparates ao

Chiarello afirma: “(...) contradições que marcam a filosofia tardia já se faziam presentes no programa do materialismo interdisciplinar da década de 1930, apenas agora radicalizadas. Mais ainda, que a distensão conceitual, que se diagnostica amíúde na filosofia tardia como sobreposição de dois movimentos contrastantes, é antes um leitmotiv da obra, que se faz sentir, de fato, desde o seu começo. O que não impede de reconhecer que a radicalidade introduzida na teoria a partir da Dialética do Esclarecimento configura, efetivamente, um ponto de inflexão a mudar o perfil da obra.” Chiarello, Maurício. Das lágrimas das coisas; p. 20.

244 A esse respeito, Schmidt afirma que o processo de desencantamento do mundo diagnostico por Weber foi interpretado por Horkheimer a partir de uma outra perspectiva. Sem os pressupostos positivistas que acometia a Weber, o problema do progresso é visto, segundo Schmidt: “(...) como o problema da contradição da razão em si mesma. Uma palestra de Horkheimer em 1946, relacionada ao contexto da Dialética do Esclarecimento, investiga a tendência do progresso no século XX de destruir os ideais humanos, que deveriam ser mantidos e desenvolvidos. A civilização técnica ameaça os seus próprios resultados: 'a capacidade de pensamento autônomo'. O indivíduo paga pelas grandes conquistas da indústria, as suas crescentes habilidades técnicas, a abundância de mercadorias e de serviços com a intensificação da 'impotência diante do poder fechado da sociedade, que deveria ser verdadeiramente controlado. Toda a sua existência se vê constantemente ocupada em remodelar até mesmo os seus impulsos mais sutis por padrões pré-fabricados de comportamento e emoção'.” Schmidt, Alfred. “Aufklärung und Mythos im Werk Max Horkheimers”; p. 198.

245 A esse respeito, segundo Horkheimer: “O declínio do indivíduo deve ser atribuído não às realizações técnicas do homem e nem mesmo no próprio homem - as pessoas são geralmente melhores do que pensam, dizem ou fazem mas sim à atual estrutura e conteúdo da "mente objetiva”, o espírito que penetra a vida social em todos os seus setores. (...). A mente objetiva da nossa época cultua a indústria, a tecnologia e a nacionalidade sem nenhum princípio que dê um sentido a essas categorias; espelha a pressão de um sistema econômico que não admite tréguas nem fugas.” Horkheimer, Max. Eclipse da razão; p. 158. 
projetar matadouros organizados com eficácia industrial. Segundo Horkheimer:

Destituído do seu fundamento racional, o princípio democrático torna-se exclusivamente dependente dos chamados interesses do povo, e estes são funções das forças econômicas cegas ou mais do que conscientes. Não oferecem quaisquer garantias contra a tirania. No período do sistema de livre mercado, por exemplo, as instituições baseadas na ideia dos direitos humanos foram aceitas por muita gente como um bom instrumento de controle do governo e manutenção da paz. Mas se a situação muda, se poderosos grupos econômicos acham útil estabelecer uma ditadura e abolir a regra da maioria, nenhuma objeção fundada na razão pode se opor à sua ação. Se eles têm uma real oportunidade de êxito, seriam simplesmente tolos de não aproveitá-la. A única consideração que poderia detê-los seria a possibilidade de que os seus próprios interesses estivessem em risco, sem ter nada a ver com a violação da verdade ou da razão. ${ }^{246}$

Isto posto, convém examinar o modo que Weber discutiu essas mutações no interior do conceito de razão. Em “Consideração intermediária”, a esfera intelectual é apresentada como o campo no qual as religiões da salvação encontraram-se em estado de maior e mais profunda tensão.

Se na economia e na política os embates entre as éticas religiosas e a legalidade própria dessas esferas foram mais gritantes e evidentes; se com relação à estética e ao erotismo os vínculos fraternais são desafiados por aspectos não-racionais ou mesmo irracionais; no que tange à atividade intelectual, o conflito se arma de uma maneira mais arraigada.

Ao abrigar em seu interior demandas de explicação e de justificação racionais de seus dogmas e de suas doutrinas, as religiões da salvação prestaram um inestimável serviço no surgimento e no desenvolvimento do pensamento laico. Todavia, como se parisse um filho ingrato, desencadearam também o processo que, a um só tempo, desfigurou a razão e condenou as religiões a se embrenharem em rotas mais turvas ${ }^{247}$. De sede originária das formulações mais racionais e abstratas dos princípios éticos, esse caminho fez com que elas fossem condenadas a purgar suas astúcias e seus pecados em zonas mais sombrias. Em “Consideração intermediária”:

246 Ibidem; p. 33.

247 Obviamente, tal concatenamento de fenômenos se realizou plenamente apenas no Ocidente e atingiu o seu ápice com a modernidade capitalista. Mais uma vez, a questão está imbrincada ao processo de desencantamento do mundo analisado por Weber. Segundo Schluchter: "Para Weber, portanto, há não apenas diferentes tipos de racionalismo e racionalização, não apenas diferentes esferas da vida que podem ser racionalizadas, não apenas diferentes portadores de racionalização e, como uma consequência, não apenas diferentes tipos de ordem racional e tipos de racionalização; há além disso tudo, um fenômeno especial de racionalismo e racionalização que possui um problema histórico de identificação e explanação e por isso demanda uma 'teoria histórica' adequada. Esta teoria não pode ser uma teoria de estágios universais; nem pode ser restrita a uma comparação tipológica. A teoria deve prover uma perspectiva de desenvolvimento histórico (entwicklungsgeschschtlich). Deve ser capaz de prover uma explanação válida da particularidade do racionalismo e da racionalização ocidental”. Schluchter, W. The rise of western rationalism; p. 12. 
Mas não foram só esses interesses muito próprios dos sacerdotes que condicionaram a conexão sempre renovada da religião com o intelectualismo, mas também a pressão interna devida ao carácter racional da ética religiosa e a necessidade de redenção especificamente intelectualista. No fim de contas, cada religiosidade adoptou, tanto no seu fundamento psicológico e mental como nas suas consequências práticas, uma posição diferente em relação ao intelectualismo, sem que, no entanto, jamais desaparecesse o efeito dessa última tensão interna, que reside na disparidade inevitável das conformações finais dadas à imagem do mundo. Não há absolutamente religião nenhuma, desde que fosse vigorosa e actuasse como força vital, que, num dado ponto, não tivesse tido que exigir o “credo non quod, sed quia absurdum" - ou seja, o "sacrifício do intelecto". ${ }^{248}$

Ora, em suas formas mais elementares, as ações magicamente orientadas se assentavam na expectativa de uma unidade perfeita em torno dos elementos ritualísticos e das imagens de mundo. Ao manipularem a natureza ou ao recomendarem certas práticas mágicas, os feiticeiros acreditavam e faziam crer que os objetos mobilizados em um ritual não apenas eram capazes de obter efeitos reais, como também correspondiam imediatamente à materialidade de relações concretas. Pouco a pouco, no entanto, a simbologia foi-se descolando da matéria bruta e o seu caráter efetivamente real sublimou-se em vínculos metonímicos. A ferramenta de abstração atuante nesse processo fez florescer no interior das comunidades humanas toda uma sorte de ações sociais que não se reduziam integralmente à imediaticidade de relações factuais.

Face a esse processo, entre avanços e recuos, a vida religiosa deixou de se prender ao tradicionalismo e à concretude das práticas mágicas, tornando-se objeto de uma espiritualização crescente $^{249}$ - o destino dos fieis deixa de ser pautado pela pela magia em favor de uma conduta de vida racionalizada. As religiões da salvação não poderiam somente recomendar certas práticas a seus seguidores, mas deveriam elaborar um sentido que justificasse os infortúnios e a bem-aventurança. Para Weber o protestantismo é a doutrina religiosa racionalmente mais coerente. Nenhuma outra religião levou a cabo de maneira tão radical o processo de desencantamento do

248 Weber, Max. “Consideração intermediária”; p. 349.

249 Nas diversas religiões da salvação, as camadas dos intelectuais desempenharam um papel decisivo nesse desenlace. Buscar um significado transcendente para a vida na Terra e articulá-lo em um sistema com algum grau razoável de coerência não é algo que brote como consequência imediata da irracionalidade dos acontecimentos sociais ou da imprescritabilidade do destino humano. Segundo Weber: "Mas por trás de qualquer delas se escondia sempre uma tomada de posição frente a algo que no mundo real se percebia como especificamente "sem sentido", assim como a exigência de que a estrutura do universo em sua totalidade era um "cosmos" dotado de sentido, ou ao menos, podia e devia ser. E precisamente essa exigência, que é o produto básico do racionalismo propriamente religioso, foi o que representaram as camadas intelectuais. Os caminhos e os resultados dessa necessidade metafísica, e também o grau de sua eficácia, foram muito diferentes. De toda forma, pode-se dizer algumas generalidades sobre eles.” Idem. “Einleitung”; p. 247. 
mundo ${ }^{250}$. A magia é vista como a manifestação direta do próprio demônio e os sacramentos não devem ser respeitados pela expectativa de conquistar alguma simpatia de Deus.

Contudo, mesmo as religiões que não atingiram esse extremo grau de coerência lógica se veem afetadas pela adoção de uma teologia sistemática. O mundo como um cosmos ordenado por Deus é inconciliável com qualquer observação empírica da realidade. A incomunicabilidade da experiência mística se transformaria, ao mesmo tempo, no calabouço mais bem vigiado e no refúgio mais confortável para as religiões. Ainda que se consolidasse a ideia de que as religiões apenas conhecem os caminhos da salvação, mas não conseguiriam justificá-los racionalmente, o cristal não esconderia suas rachaduras. Os seus mistérios permanecem como tal - isto é, insondáveis à razão e o sentido atribuído ao mundo tem de se conformar em ser revelado por meio de uma vivência imediata, mas indisponível a qualquer pretensão metódica de conhecimento. Segundo Weber:

Quanto menos ela for magia ou mera mística contemplativa e mais ela for “doutrina”, tanto mais se lhe impõe a necessidade de uma apologética racional. Foi dos feiticeiros, que em toda parte se tornaram típicos guardiães dos mitos e das lendas heróicas, por participarem na educação e formação dos jovens guerreiros, a fim de provocar neles o êxtase heróico ou de os preparar para renascer como heróis, que os sacerdotes - únicos capazes de manter a perenidade de uma tradição, retomaram a formação da juventude em matéria de lei e, muitas vezes, também de técnicas puramente administrativas: sobretudo, a escrita e o cálculo. Então, quanto mais a religião se foi tornando religião do Livro e doutrina, tanto mais literária se tornou e, por consequência, tanto mais suscitou um pensamento laico racional, livre da tutela sacerdotal. ${ }^{251}$

Além das consequências desses desdobramentos imanentes das ideias religiosas, Weber

ressalta também o papel da ciência para esse desenlace. Do surgimento do conceito com Sócrates,

passando pelo uso da experimentação racional durante o Renascimento, a razão passou a ser

250 Por exemplo, as diversas denominações protestantes apresentam algumas concessões ao grau máximo de coerência do calvinismo. Embora compartilhassem muitos e decisivos elementos, a aproximação realizada pelo pietismo, pelo metodismo e pelas seitas anabatistas de rituais extáticos e de uma doutrina religiosa sentimental implicou direto em algum comprometimento do ascetismo intramundano marcado a ferro e fogo pela doutrina de Calvino. Segundo Weber: 'É possível então apontar, até onde chega nosso ponto de vista, que essa era a marca decisiva do 'pietismo' no campo calvinista. Pois o fator do sentimento, originalmente estranho à piedade calvinista como um todo, porém intimamente aparentado com certas formas da religiosidade medieval, desviara a religiosidade prática para os trilhos do gozo da bem-aventurança eterna já que neste mundo, em detrimento da luta ascética com vistas a ter certeza quanto ao futuro no Outro Mundo. E esse sentimento podia intensificar-se a tal ponto que a religiosidade assumia um caráter francamente histérico e produzia então, conforme mostram inúmeros exemplos, uma alternância de fundo psicológico [neuropático] entre estados semiconscientes de êxtase religioso e períodos de letargia nervosa re-sentidos como 'afastamento de Deus', cujo efeito era exatamente o inverso daquela disciplina sóbria e rigorosa na qual a vida santa sistematizada do puritano capturava o indivíduo: um enfraquecimento daquelas 'inibições' que escutavam a personalidade racional do calvinista contra os 'afetos'.” Idem. A ética protestante e o “espírito” do capitalismo; p. 118-119.

251 Idem. “Consideração intermediária”; p. 349. 
concebida não como um caminho capaz de desvendar e conduzir à verdadeira natureza das coisas, mas sim como um instrumento criado a fim de possibilitar uma resposta à seguinte indagação: o que devemos fazer se quisermos nos assenhorar tecnicamente da natureza?

Para tanto, as formulações religiosas, sempre relacionadas a determinados princípios substantivos, não oferecerem respostas satisfatórias. Por mais que as religiões tenham considerado as investigações empíricas como conciliável com seus interesses ${ }^{252}$, a ciência moderna apresenta resultados melhores e menos custosos. Cedo ou tarde, esbarra-se com o requisito fundamental de compreender o mundo consoante uma constituição ética. Algo que para a observação empírica da realidade, sobretudo a matematicamente orientada ${ }^{253}$, é um completo contrassenso. Paulatinamente, a vertente laica da razão destronou a forma sacra e assumiu seu posto. O saldo final foi a pavimentação de um trajeto rumo ao desenvolvimento do racionalismo dissociado de qualquer componente substantivo. A última transformação operada por esse longo processo, a um só tempo, o esvaziou a razão de sentido e condenou o destino da religião à esfera da irracionalidade. Segundo Weber:

\begin{abstract}
A necessidade de redenção, cultivada conscientemente como conteúdo de uma religiosidade, surgiu sempre e em todo o lado como consequência da tentativa de racionalização sistemática e prática da vida; só que esse contexto se conservou com uma nitidez muito variável. Ou, por outras palavras, nasceu da pretensão - que, nessa fase, se torna o pressuposto específico de toda a religião - de que o curso do mundo, pelo menos tanto quanto toca aos interesses dos homens, seria um processo de algum modo dotado de sentido. Essa pretensão surgiu naturalmente, como vimos, identificada em primeiro lugar com o problema habitual do sofrimento injusto; portanto, como postulado de uma compensação justa para a repartição desigual de felicidade individual no seio do mundo. Pois quanto mais intensamente o pensamento racional se ocupasse desse problema de compensação que restabeleceria a justiça, tanto menos a sua solução puramente intramundana podia parecer possível, e tanto menos verosímil ou razoável uma solução extramundana. ${ }^{254}$
\end{abstract}

A ciência moderna triunfa. As condições a serem cumpridas para uma vida santificada, as formulações a respeito dos modos de conduta pecaminosos, as obrigações que os fieis deveriam devotar aos outros homens, em suma, todas as elaborações religiosas para a correta ordenação da relação de seus seguidores com a sociedade e com a natureza já não podem mais reivindicar para si 
os direitos - e os deveres - de serem consideradas racionais. O que as religiões universais visavam regulamentar prende-se à substância de uma ética da vida; a razão, por seu turno, tece seus caminhos como um invólucro formal. O pensamento só se torna verdadeiramente racional na medida em que abdica de qualquer volição normativa. Os conceitos científicos espelham tais transformações da razão. A interpretação da realidade empírica só é possível quando se abandona pretensões de formulação de um saber objetivo. A composição de tipos-ideais está necessariamente condicionado a pressupostos subjetivos do cientista. Porém, é precisamente isso que confere valor às ciências da cultura. Para não ressuscitar dogmatismos de qualquer ordem, o pensamento científico deve permanecer dentro de limites estritos. Apenas os seus resultados são passíveis de determinado grau de objetividade. Porém nunca significará assumir uma posição em relação às disputas e aos conflitos constituintes da vida social. Em “A 'objetividade' do conhecimento nas ciências sociais”:

Somente religiões positivas - mais precisamente, seitas de caráter dogmático conseguem atribuir ao conteúdo de valores culturais a dignidade de deveres éticos incondicionalmente válidos. Fora delas, os ideias culturais que o indivíduo quer e as obrigações éticas que ele deve cumprir são de dignidade diferente por princípio. É destino de uma época cultural que provou do fruto da árvore do conhecimento ter que saber que não podemos discernir o sentido do andamento do mundo nem mesmo da mais completa investigação, mas que nos cabe cria-lo nós próprios, que "concepções de mundo" jamais podem ser produto do avanço de um saber empírico, e que portanto os ideias mais elevados, que mais intensamente nos comovem, agora e sempre só se efetivam no combate com outros ideais tão sagrados para outros quanto os nossos são para nós. ${ }^{255}$

Horkheimer avalia esses fenômenos de maneira completamente distinta. Para o frankfurtiano, a formalização da razão reacende apenas os seus aspectos problemáticos e controversos. Passo a passo, os seus efeitos mutiladores foram se consolidando. A possibilidade de descambar em loucura coletiva - os campos de concentração ou as reações da cultura de massas - já se encontrava latente desde a primeira vez que o homem contemplou, calculadamente, a natureza como uma presa. Porém, apenas as modernas sociedades industriais conseguiram levar a cabo tais tendências.

Como já foi dito anteriormente, de acordo com Horkheimer, a história de nossa civilização

255 Idem. “A 'objetividade' do conhecimento nas ciências sociais”; p. 21. 
se resume a um antagonismo destrutivo entre os indivíduos e a natureza. Órgão humano de controle e de domínio, a razão se desgovernou completamente com o desenvolvimento tecnológico que prometia subjugar integralmente a natureza. Nessa sua figura sistemática e calculista, o processo se autonomizou e se transformou em um instrumento de repressão - inclusive e sobretudo - da própria natureza interna dos sujeitos. Aqueles que se imaginavam senhores de todas as coisas se encontram convertidos na mais tristes das funções. Mesmo que conseguissem silenciar a natureza, a batalha já estaria perdida de antemão.

A luta é inglória. A vida social é o resultado do intercâmbio contínuo entre os homens e a natureza, cuja contenda nunca chegaria a um termo. A luta é também traumática, pois deturpa tanto os que se imaginam ser os vencedores como também tudo o que é subjugado. Por não se adequar sempre e imediatamente ao uso humano, a natureza é vista como uma mixórdia de substâncias heterogêneas e sem significado imanente, enquanto o homem se deixa perceber apenas como ave de rapina, despojando-se de qualquer outro objetivo que não seja o de sua autopreservação. Por fim, a luta é ainda catastrófica. Em vez de fazer nascer um verdadeiro entendimento entre os polos que se imaginam opostos, repõe-se o antagonismo em níveis cada vez mais elevados, ultrapassando até mesmo os limites do absurdo. Segundo Horkheimer:

Se tivéssemos de falar de uma doença que afeta a razão, tal doença não deveria ser entendida como algo que tivesse abalado a razão em um determinado momento histórico, mas como algo inseparável da natureza da razão dentro da civilização, tal como vimos até agora. A enfermidade da razão está no fato de que ela nasceu do impulso para dominar a natureza, e a sua "recuperação" depende da compreensão interna da natureza da doença original, e não de uma cura dos seus sintomas posteriores. A verdadeira crítica da razão descobrirá necessariamente os substratos mais profundos da civilização e explorará a sua história mais antiga. Desde o tempo em que a razão se tornou o instrumento para a dominação da natureza humana e extra-humana pelo homem - quer dizer, desde as suas próprias origens - ela tem se frustrado em sua intenção de descobrir a verdade. ${ }^{256}$

O Iluminismo poderia ter significado uma atitude por meio da qual os dogmatismo e os proselitismos religiosos fossem destituídos racionalmente de seus fundamentos. Se a religião foi capaz de algum dia congregar elaborações substancialmente racionais em meio a tantas outras mistificações, a fúria dos ataques esclarecidos extrapolaram em demasia o que deveria ser o seu 
alvo. O despudor não permitiu nenhum limite à sua sanha, e a filosofia iluminista não apenas abalou as alicerces das igrejas como também feriu mortalmente a metafísica e o conceito objetivo de razão. Qualquer especulação que pretendesse apreender a verdadeira natureza da realidade e determinar os corretos princípios que guiam a vida humana recebe imediatamente a pecha de mitologia e de superstição.

Da Grécia Antiga à era burguesa, a postura intolerante contra esse tipo de elaboração teórica foi, progressivamente, ganhando mais adeptos. Com os trajes de seus acusadores cheirando a mofo, conceitos vinculados com a ideia de bem supremo, preocupações com o problema do destino humano e a realização de fins transcendentes foram, amiúde, desacreditados como obsoletos. De acordo com Horkheimer, não são essas as condições necessárias de um pensamento sadio. Para tanto, é preciso preservar, mesmo nos momentos em que esteja prestes a se contradizer, as lembranças de todo o processo pelo qual a verdade fora alcançada ${ }^{257}$.

Por seu turno, a memória da ilustração mostrou ser curta e para lá de seletiva. Em vez do trabalho demorado de reflexão teórica intransigente, no qual os saberes procuravam descobrir a natureza das coisas e derivar daí os modos corretos da atividade humana, foi-se fortalecendo a convicção de que nada além da reprodução contínua do existente está disponível para a humanidade. O empirismo, com sua maneira de enxergar na metafísica apenas discussões bizantinas em torno de pseudoproblemas, e o calvinismo, por meio de sua doutrina de Deus abconditus, elevaram o paradoxismo dessa situação ao ponto máximo. Um colégio de cardeais na Idade Média, na medida em que precisavam se reportar aos evangelhos para sustentar suas posições, parece se utilizar mais a razão do que um grupo de cientistas discutindo os rumos e o direcionamento de um projeto de pesquisa ${ }^{258}$. Segundo Horkheimer:

A razão denotava então o ponto de vista dos scholars, estadistas e humanistas, que julgavam os conflitos de doutrinas religiosas mais ou menos desprovidos de significado em si mesmos, e consideravam-nos como slogans ou artifícios propagandísticos de facções políticas diversas. Para os humanistas não havia qualquer incoerência em que um povo vivesse sob determinado governo e determinadas fronteiras e ainda assim professasse

257 Ibidem; p. 67. 258 Ibidem; p. 84. 
religiões diferentes. Tal governo tinha propósitos seculares. Não estava dentro das suas intenções, como Lutero pensava, disciplinar e castigar a fera humana, mas apenas criar condições favoráveis para o comércio e a indústria, para solidificar a lei e a ordem, para assegurar aos seus cidadãos a paz dentro do país e a proteção fora do mesmo. Em relação ao indivíduo, a razão exercia agora o mesmo papel que exercia na política através do estado soberano, e que se relacionava com o bem-estar do povo e se opunha ao fanatismo e à guerra civil. ${ }^{259}$

O positivismo, talvez, seja o desenlace mais coerente de tal concepção da razão e - por esse motivo - deve ser duramente combatido. Para Horkheimer, as suas principais correntes teóricas revelariam uma relação dúbia com o pensamento de Weber. Por um lado, a tese weberiana da necessidade de formulação de um conhecimento axiologicamente neutro no âmbito das ciências sociais retira, por mais uma vez, a possibilidade de compreensão do papel da ciência no atual quadro das sociedades capitalistas. No entanto, se em Weber havia ainda uma certa hesitação em adotar sem mais as categorias e os procedimentos das ciências naturais para o conhecimento sociológico, o positivismo perdeu esses pudores. Segundo Horkheimer:

Os positivistas reduzem a ciência aos procedimentos utilizados na física e suas ramificações; recusam o nome de ciência a todos os esforços teóricos que não estão de acordo com o que eles retiram da física como seus métodos legítimos. Deve-se observar aqui que a divisão de toda a verdade humana em ciência e humanidades é ela própria um produto social que foi constituído substancialmente pela organização das universidades e fundamentalmente por algumas escolas filosóficas, em particular as de Rickert e Max Weber. O chamado mundo prático não tem lugar para a verdade, e portanto a divide em frações para conformá-la à sua própria imagem: as ciências físicas são adotadas da chamada objetividade, mas esvaziadas de conteúdo humano; as humanidades preservam o conteúdo humano, mas só enquanto ideologia, a expensas da verdade. ${ }^{260}$

Por outro, provavelmente com alguma ingenuidade e certamente sem nenhum direito, o positivismo pretendeu usurpar todas as funções da razão. Imaginou-se capaz de realizar aquilo que a especulação tradicional ambicionara, mas não cumpriu. Com uma esperança deslocada e curiosa, as vertentes mais recentes do positivismo ${ }^{261}$ não podem ser acusadas de ignorar plenamente os efeitos

259 Ibidem; p. 19.

260 Ibidem; p. 80.

$261 \mathrm{Em}$ Eclipse da razão, Horkheimer se refere explicitamente sobretudo ao pragmatismo norte-americano, representado por John Dewey, Sidney Hook e William James. Em The Frankfurt School in Exilie, Thomas Wheatland apresenta uma discussão bastante interessante sobre as relações entre Horkheimer e Sidney Hook. Em alguma medida, de acordo com a avaliação de Wheatland, as diferenças entre a teoria crítica e o pragmatismo norte-americano são menos agudas do que se poderia acreditar intuitivamente. Grande responsável pela divulgação da obra de Marx principalmente nos círculos intelectuais de Nova Iorque, o pragmatismo de Hook revelaria preocupações sensivelmente similares com alguns temas caros ao frankfurtiano. A esse respeito, segundo Wheatland: "No começo dos anos 30, ambas filosofias responderam à crise da modernidade no pós Primeira Guerra procurando localizar um caminho entre um subjetivismo radical e o materialismo. A teoria crítica e o pragmatismo, assim, eram igualmente hostis à metafísica, ao idealismo, à fenomenologia e às várias manifestações de irracionalismo que surgiram durante a década de 1920. Simultaneamente, ambos eram similarmente hostis ao puro 
destrutivos aos quais a ciência fora destinada.

Porém, estes são equivocadamente associados ao suposto desvirtuamento dos procedimentos científicos e dos usos da tecnologia. Passadas as tormentas, bastaria que a ciência moderna voltasse ao seu funcionamento normal e legítimo para que o otimismo com relação ao futuro pudesse ser também restabelecido. Que a racionalidade instrumental tenha sido utilizada para a produção de um sistema de morticínio em larga escala não deveria ser motivo de maiores alarmismos.

Aquém de Weber, a crença se baseia na suposição de que as inúmeras antinomias teóricas e as recorrentes contradições sociais seriam magicamente solucionadas com o aprofundamento dos mesmos preceitos que fomentaram a efetivação da barbárie. Embora lhe seja ausente critérios imanentes para distinguir ações horríveis e condições desumanas, o positivismo se dá por satisfeito com suas promessas vazias e abstratas. A aplicação da ciência em melhoramentos tecnológicos conseguiria finalmente realizar o ideal cientificista que remonta aos tempos de Platão. A única maneira de salvar a humanidade seria submetê-la às regras e ao método do raciocínio científico ${ }^{262}$. Segundo Horkheimer:

Esta se torna a função da ciência em relação aos valores tal como são definidos por Max Weber, um positivista no fundo. Weber, contudo, estabeleceu diferenças precisas entre conhecimento científico e valores, e não acreditou que a ciência experimental pudesse por si mesma superar antagonismos sociais e políticos. Mas está bem dentro da linha das ideias do positivismo reduzir o que lhe escapa como "valores" a fatos, e representar as coisas do espírito com algo reificado, um tipo de mercadoria ou produto cultural especial. $\mathrm{O}$ pensamento filosófico independente, crítico e negativo como é, deve erguer-se acima tanto do conceito de valores quanto da ideia da absoluta validade dos fatos. ${ }^{263}$

Entretanto, essa idolatria em torno do cálculo de probabilidades e da classificação dos fatos

não leva à verdade. Antes o contrário, ela reproduz a heteronomia dos indivíduos ao reiterar ad nauseam uma hostilidade da mesma estirpe daquela que o homem encerrado na caverna alimentava

formalismo matemático da lógica e ao positivismo - embora Dewey e Hook eram mais simpáticos aos estudos do positivismo lógico, a experiência individual permanecia ainda a base do instrumentalismo pragmático deles” Wheatland, Thomas. The Frankfurt School in Exilie; p. 235. Apesar de tais proximidades, o autor não deixa de reconhecer algumas essenciais rupturas entre eles, notadamente em suas respectivas noções acerca da lógica dialética, do valor do legal de Hegel e da própria ciência em si. Segundo Wheatland: "Horkheimer, argumentando do ponto de partida do materialismo histórico, apontava a teoria do conhecimento pragmática como um sintoma de uma crise mais geral que ele diagnosticara na lógica científica. Reconhecendo a incorporação da ciência nos meios de produção da civilização burguesa, Horkheimer compreendia o pragmatismo como uma distorção da lógica científica que derivava seus critérios de conhecimento de sua utilidade.” Ibidem; p. 248.

262 Horkheimer, Max. Eclipse da razão; p. 65.

263 Ibidem; p. 86. 
contra tudo que lhe parecesse estranho ${ }^{264}$. Entrelaçada a essa conduta, Horkheimer chama atenção para a atuação de uma nova forma de encantamento que, a princípio, parecia não ter lugar nas sociedades modernas. A razão formalizada mostra-se responsável pelo surgimento de inúmeras mistificações. Tal como a natureza que só é percebida sob o aspecto de sua exploração cada vez mais eficaz, aqueles que tenham pele de cor diferente, que cultivem hábitos considerados fora do comum se tornam objeto de ódio justamente por estarem além das rígidas fronteiras do que é tido como normal. Seus hábitos são estereotipados e ridicularizados a fim de convencer a todos os demais que o existente tal como ele se apresenta em sua imediaticidade é a única forma de existência possível, tolerável e racional.

A postura conformista ante a vida social põe em cena o seu lado mais selvagem. O medo das incertezas de um mundo novo congela os homens. A energia que poderia levá-los à realização plena de suas potencialidades é deturpada para que se adaptem a um figurino apertado e falso. Em vez de romper as amarras da atual situação de minoridade, os indivíduos parecem preferir renunciar à toda esperança avançando ferozmente contra qualquer forma de alteridade. Ao confundir o bem e a verdade com a realidade existente, essa forma da razão distorce a percepção humana e ajuda a trilhar a rota que conduz o que fora construído como historicamente racional a tipos de dominação social mais horrendamente bárbaros ${ }^{265}$. Segundo Horkheimer:

Se a renúncia final ao impulso mimético não promete conduzir à realização das potencialidades humanas, esse impulso estará sempre à espreita, pronto para emergir como uma força destrutiva. Isto é, se não existe outra norma além do status quo, se toda a esperança de felicidade que a razão pode oferecer é preservar o existente tal como ele é e mesmo aumentar suas pressões o impulso mimético jamais pode ser verdadeiramente superado. (...). A esse respeito, o homem moderno não é muito diferente do seu antecessor medieval, exceto na escolha de suas vítimas. Os procritos da política, as seitas religiosas excêntricas como o Bibelforscher alemão, e os zootsuiters, tomaram o lugar das bruxas, feiticeiros e heréticos; e existem ainda os judeus. Qualquer um que tenha assistido um comício nacional-socialista na Alemanha sabe que os oradores e a audiência retiravam a sua principal emoção ao exibir impulsos miméticos socialmente reprimidos, mesmo quando ridicularizavam e atacavam inimigos raciais acusados de ostentarem imprudentemente os seus próprios hábitos miméticos. O ponto alto de tais comícios era o momento em que o orador representava o papel de judeu. Ele imitava aqueles que queria ver destruídos. As imitações provocavam uma estridente hilaridade, pois um impulso natural proibido podia se afirmar sem temor de censura. ${ }^{266}$

264 Ibidem; p. 90.

265 Ibidem; p. 131.

266 Ibidem; p. 121. 
As horas se tornaram mais escuras, mas Horkheimer afirma não partilhar o pessimismo que acometeria a Weber. Mais urgente do que elaborar um plano de ação política, a crítica conceitual a esses desdobramentos teóricos e práticos da razão instrumental é o ponto de partida para manter aceso algum alento ${ }^{267}$. Chamar a realidade por seu nome legítimo, isto é, expressar o significado das coisas e da vida, dar voz a tudo que foi calado, dotar a natureza de um órgão capaz de manifestar os seus sofrimentos são os desafios do pensamento.

Em nenhuma medida, a tarefa se limita a imaginar a sociedade emancipada nos termos de uma economia plenamente planificada e centralizada como contraponto ao capitalismo anárquico. Em uma sociedade que se encontra nas mãos de um reduzido número de trustes e de carteis, insistir apenas nesse ponto soa como uma farsa ${ }^{268}$. Conquanto o mundo continue a ser dividido em grupos hostis e em blocos político-econômicos que exigem ainda uma organização substancialmente racional das sociedades, a própria condição do indivíduo submetido a essa situação se revela suscetível a irracionalidades de outro jaez.

A crítica à formalização da razão contribui para a alteração desse degradante estado das coisas. A esperança de fazer reviver a perdida espontaneidade dos sujeitos é depende de uma outra configuração da razão. Entre a sua instrumentalização completa e o opressivo dogmatismo de outrora, que fazia confundir a verdade objetiva com convenções tradicionais, somente o pensamento concebido como crítica intransigente do presente é capaz de relacionar corretamente as legítimas

267 A esse respeito, de acordo com Demirovic: "Caso a sociedade se desenvolvesse da maneira como Horkheimer e Adorno prognosticaram, a teoria também deixaria de existir. Porém, com isso, mesmo a sociedade capitalista também se alteraria drasticamente. A teoria crítica é a postura que adverte sobre o perigo de uma sociedade na qual a necessária crítica da sociedade permanece silenciada. Somente a permanência da teoria é que garante a sobrevivência da tendência à uma concepção racional e livre da sociedade. Por si mesmo, conservar a teoria representaria uma intervenção prática no curso das tendências atuantes no processo social.” Demirovic, Alex; Der nonkonformistische Intellektuelle; págs. 36-37.

268 A esse respeito, acredito que a interpretação realizada por Martin Jay do pensamento de Horkheimer é parcial. Ao procurar diferenciar Horkheimer da sociologia weberiana, Jay afirma que as sociedades modernas não poderiam ser consideradas racionais como Weber parece fazer crer, pois a administração da economia permanecia irracional. Segundo Jay: "Como marxistas, seus membros repudiavam a idéia de que uma economia não planejada, sem meios de produção socializados, pudesse ser racional. Portanto, a autoridade política, numa sociedade capitalista, não poderia ser racional no sentido substantivo de conciliar interesses particulares e gerais.” Jay, Martin. The dialetical imagination; p. 171. As críticas de Horkheimer a Weber, por meio da qual pude discutir alguns aspectos da própria irracionalidade das sociedades modernas, ultrapassam em larga medida as reivindicações ainda necessárias por planejamento e centralização econômicas. 
demandas subjetivas e uma realidade social que promova, em vez de eclipsar, as potencialidades humanas. Segundo Horkheimer:

Agora que a ciência nos ajudou a superar o medo do desconhecido na natureza, somos escravos das pressões sociais em relação à própria construção de nós mesmos. Quando somos instados a agir independentemente, clamados por modelos, sistemas e autoridades. Se por evolução científica e progresso intelectual queremos significar a libertação do homem da crença supersticiosa em forças do mal, demônios e fadas, e no destino cego - em suma, a emancipação do medo então - a denúncia daquilo que atualmente se chama razão é o maior serviço que a razão deve prestar. $^{269}$

269 Horkheimer, Max. Eclipse da razão; págs. 191-192. 


\section{Cap. 3 - A dialética negativa de Adorno em Weber.}

Se para certa matriz de análise a publicação da DE é o momento de viragem dos frankfurtianos em direção a uma crítica que se desdobra em contradições teóricas imanentes, o pensamento tardio de Adorno é identificado por muitos como a formulação conceitualmente mais sofisticada e, talvez com um certo grau de paradoxismo, a que mais padeceu entre os autores da teoria crítica da equivocidade de uma interpretação em bases tão radicais da razão ocidental e das sociedades modernas. Enquanto a obra posterior de Horkheimer estaria confinada no obscurantismo de um retorno - pessimista e lamentoso - ao mundo das teologias e das doutrinas religiosas, Adorno se refugiaria em um discurso filosófico sem saída e em um conjunto de reflexões estéticas de recorte aristocrático. Conquanto ainda pudessem ser estimulantes, haveria um decréscimo significativo em sua capacidade interpretativa a respeito da concretude da vida em sociedade. Além da crítica ter se tornado míope em relação ao mundo social coetâneo, a negatividade da dialética adorniana demarcaria também os limites práticos de um pensamento ensimesmado em suas próprias antinomias conceituais.

A esse respeito, de acordo com Habermas, o pensamento de Adorno condensa o fim de linha de uma teoria centrada na filosofia da consciência. Ao levar adiante o projeto de desvendar com os conceitos aquilo que seria o não-conceitual, o frankfurtiano trouxe para o interior da reflexão filosófica antinomias semelhantes às encontradas também na sociologia de Weber. Na verdade, o autor da DN teria aferrado-se ainda mais aos desenganos daqueles que entenderam a racionalização social meramente como um fenômeno de coisificação da consciência. Embora o sociólogo de Heidelberg não tenha sequer vislumbrado a necessidade de uma mudança de paradigma para a crítica sociológica - não mais centrada na ação teleológica, mas atinada aos desdobramentos próprios da ação comunicativa -, a sua interpretação da modernidade ocidental não implicava em um diagnóstico de colonização irreversível do mundo da vida pela expansão indômita da ação racional com relação a fins. Mesmo que se tenha negligenciado o potencial comunicativo de uma 
outra racionalização orientada pelo entendimento, Habermas afirma ser possível construir uma crítica aos fundamentos de sua teoria da ação a partir de outros argumentos já esboçados por Weber.

\section{Em Teoria do agir comunicativo:}

Por situar sua teoria da ação em uma via por demais estreita, Weber não consegue reconhecer no dinheiro e no poder meios de comunicação que, ao substituírem $a$ linguagem, tornam possível a autonomização e diferenciação de sistemas parciais do agir racional-teleológico. Esses meios, e não indiretamente as orientações racional-teleológicas da ação, carecem de uma ancoragem institucional e motivacional no mundo da vida: a legitimidade da ordem jurídica e o fundamento moral-prático para campos de ação legalizados (isto é, campos de ação formalmente organizados) constituem elos que vinculam ao mundo da vida o sistema administrativo diferenciado pela via do poder e o sistema econômico diferenciado pela via do dinheiro. Weber tinha razão ao abordar esses dois complexos institucionais, à medida que pretendia decifrar a modernização como racionalização contraditória em si mesma. ${ }^{270}$

Adorno não mais portaria essas indecisões. Ao se apropriar das questões trazidas pela sociologia weberiana por intermédio de Lukács, a aridez de seu texto e a profundidade de seu pensamento imunizaram-no contra o idealismo que ainda se embaralhava na dialética do autor de HCC. Porém, se o caráter formal da racionalidade moderna já não é visto como um obstáculo ao aprofundamento de relações reificadas entre os indivíduos e no interior de suas vidas anímicas, tampouco parece existir para o frankfurtiano qualquer outro espaço de respiro. Ainda que houvesse, o caminho que conduz à verdade não seria trilhável por vias discursivas. Conforme a interpretação de Habermas, a filosofia social adorniana se mostraria totalizante e contemplativa.

Ao mesmo tempo em que defendia a proeminência da teoria sobre a prática, Adorno afastava intencionalmente a primeira da própria compreensibilidade. A sua filosofia social pretendia discutir as condições de uma sociedade justa e de uma vida já não danificada. Forjada em termos ainda mais abstratos do que os da versão à razão instrumental dos anos de 1940, a crítica de Adorno ao princípio de identidade aspirava fundamentar uma relação emancipada entre sujeito e objeto. O seu resultado seria uma reflexão certamente erudita, mas tortuosa e algo confusa a respeito do potencial utópico contido em seu conceito de mímesis.

Ademais, o próprio ato de nomear essa relação toda especial já traria consigo os incontornáveis temores da dominação da natureza. O papel da filosofia se limitaria a deixar que a 270 Habermas, Jürgen. Teoria do agir comunicativo; p. 589-590. 
verdade continue inefável e procurar a sua manifestação em obras de arte por suas formas completamente negativas - quando muito, entre escombros e em meio a vestígios. A única alternativa aberta para quem acredita que a reificação teria adentrado definitivamente nos modos da linguagem e, portanto, o potencial utópico inscrito em uma situação ideal de fala só poderia lhe parecer um disparate. Segundo Habermas:

Diversamente de Marcuse, Adorno não pretendeu mais apontar uma saída dessa aporia, sendo nesse ponto mais consequente que Horkheimer. A Dialética negativa tem caráter duplo: é uma tentativa de circunscrever o que não pode ser dito por via discursiva; e é também uma advertência sobre buscar refúgio em Hegel, nessa situação. Somente a Teoria estética vem selar a transferência de competências cognitivas da arte, em que a faculdade mimética ganha forma objetiva. Adorno manifesta uma pretensão teórica: para a dialética negativa e a teoria estética ainda resta a possibilidade de "uma remeter à outra, ambas em desamparo". ${ }^{271}$

Embora percorra caminhos distintos e aponte para alguns outros aspectos, a avaliação de Honneth é bastante similar. Em seu capítulo dedicado à interpretação do pensamento de Adorno em Kritik der Macht, Honneth destaca uma espécie de déficit sociológico na obra tardia do frankfurtiano. Essa guinada em direção a uma filosofia da história se manifestaria por meio de dois elementos principais, quais sejam, pelo forte distanciamento em relação às pesquisas empíricas e, consequentemente, pela incapacidade teórica de compreender o modo de organização das sociedades do pós-guerra europeu. Por enquadrar os fenômenos associados ao surgimento do nazifascismo a um estágio no inelutável processo de decadência civilizacional, o pensamento do frankfurtiano ignoraria a dimensão da ação social ao se contentar com conceitos que pressupunham a possibilidade de uma manipulação administrada do que seriam as fraquezas psíquicas humanas.

Em vez de tematizar acerca dos processos de inadequação e de contestação sociais inerentes a todo regime de sociabilização dos indivíduos, Adorno ofereceria especulações teóricas que partem de uma concepção de sociedade configurada em estruturas econômicas determinantes, sem reconhecer nenhuma margem de manobra ou para a manifestação de qualquer outra tendência contra-hegemônica. Atada a uma compreensão de tal tipo das sociedades pós-liberais, a transformação na avaliação sobre a capacidade crítica das ciências empíricas - deslocadas de

271 Ibidem, idem; p. 661. 
parceiras iguais da filosofia, como no período do materialismo interdisciplinar, a meras auxiliares subordinadas de uma crítica teórica aporética em seus ensaios tardios - bloquearia já no princípio qualquer experiência de teoria social em Adorno. Segundo Honneth:

Como a teoria crítica ainda é possível sob as premissas de uma construção histórico-filosófica que sempre imediatamente descobre em cada ato de conhecimento conceitual o signo de um poderoso domínio humano sobre a natureza, que por seu intermédio a humanidade também é alienada? ${ }^{272}$

Todavia, essas análises me parece insuficientes em pontos decisivos. Tanto no que se refere à relação de Adorno com Weber ou com a sociologia em geral quanto para a análise do pensamento do frankfurtiano, acredito ser mais adequado arriscar uma leitura de outro tipo e, com isso, tentar fundamentar uma interpretação distinta. Talvez fosse interessante inverter o prisma de Honneth e investigar a forma pela qual Adorno se aproximou da sociologia, privilegiando para tanto as questões surgidas após o seu regresso à Alemanha. Ao longo desses anos, o frankfurtiano envolveu-se com intensidade em discussões com a teoria sociológica clássica ${ }^{273}$ e, principalmente, com correntes do pensamento social de sua época.

Em larga medida, a famigerada polêmica contra o positivismo alemão animou grande parte das reflexões de Adorno sobre a sociologia e, em especial, sobre a teoria social de Weber ${ }^{274}$. Por mais uma vez, a abordagem a esse autor se concentrou em aspectos metodológicos de seu pensamento. Não seria oportuno retomar em pormenores aquilo que fora discutido no primeiro capítulo desta tese. Porém, em comparação com os ensaios de Horkheimer dos anos de 1930, Adorno não apenas privilegiou outros elementos, mas também avaliava de maneira distinta o potencial crítico de certas categorias weberianas. Enquanto em "Teoria tradicional e teoria crítica" o

272 Honneth, Axel. Kritik der Macht; p. 63.

273 Em O Moloch do presente. Adorno e a crítica à sociologia, pretendi reconstruir de modo mais sistemático as críticas de Adorno à sociologia clássica. Com essa pesquisa realizada durante o meu mestrado, procurei recorrer aos ensaios de Adorno a respeito da sociologia de Auguste Comte e de Émile Durkheim a fim de discutir alguns elementos de sua teoria social.

274 Cito, a esse respeito, Martin Jay que destaca a relevância desse período no qual Adorno efetuara as suas mais importantes formulações sobre a sociedade e sobre a sociologia. Jay, Martin. As ideias de Adorno; p. 32. Corroborando com tal periodização, Wiggershaus é enfático ao afirmar que, após sua volta à Alemanha nos anos de 1950, além de suas aulas, da retomada de “(...) suas antigas atividades extra-universitárias de crítica musical e crítica de arte, e da adoção de novas atividades de crítica da civilização e de teórico da literatura, Adorno tornou-se sociólogo” Wiggershaus, Rolf. A escola de Frankfurt; p. 487. 
conceito de possibilidade objetiva é interpretado como a forma característica de uma concepção tradicional de ciência, em DN os tipos ideais são apresentados como modelos para a reflexão dialética.

Porém, os termos de uso de tal instrumental analítico não são nada pacíficos para Adorno, o que o impele a um debate de fôlego com aspectos fundamentais do texto de Weber. Mais do que somente relembrar os traços positivistas impregnados em seu ideal de ciência e em suas asserções metodológicas, o frankfurtiano dirige-se à essa teoria sociológica em vista de uma interpretação da totalidade social. De acordo com Adorno, Weber interpelou fenômenos decisivos ao construir a sua sociologia atinada aos aspectos racionais das sociedades modernas. Contudo, o nexo funcional que articula a vida social no capitalismo tardio afasta-se dos parâmetros da lógica por causas imanentes. Ante esse novo contexto, a reflexão sociológica não perdeu o seu objeto - embora este se torne progressivamente incompreensível ${ }^{275}$. Acompanhar com vagar os desdobramentos internos das categorias weberianas se mostra como um espaço tanto para se aperceber de algumas dessas tendências como para elaborar a sua crítica - ao Weber e à sociedade. Em "Introdução à controvérsia":

A comensurabilidade do objeto sociedade quanto ao sujeito cognoscente existe tanto como não existe; também isto dificilmente pode ser conciliado com a lógica discursiva. A sociedade é ao mesmo tempo inteligível e ininteligível. Inteligível na medida em que o estado de coisas objetivamente determinante da troca implica abstração, de acordo com sua própria objetividade, implica um ato subjetivo: nele o sujeito verdadeiramente reconhece a si mesmo. Isto explica, do ponto de vista da teoria científica, por que a sociologia weberiana está centrada no conceito de racionalidade. Nela ele procurava, não importa se conscientemente ou não, aquela igualdade entre sujeito e objeto, própria a permitir algo como o conhecimento da coisa, em lugar de seu esfacelamento em fatos reais e do tratamento mecânico destes. Contudo a racionalidade objetiva da sociedade, a da troca, pela dinâmica própria afasta-se cada vez mais do modelo da razão da lógica. Por isto a sociedade, o que se tornou autônomo, também não continua a ser inteligível; o é unicamente a lei de autonomização. ${ }^{276}$

275 A esse respeito, segundo Adorno: "É concebível que a atual sociedade seja refratária a uma teoria coerente em si. Nesse ponto Marx teve maiores facilidades, à medida que na ciência estava à sua disposição o sistema desenvolvido do liberalismo. Ele só precisava perguntar se o capitalismo, em suas próprias categorias dinâmicas, correspondia a esse modelo para, através de sua negação determinada do sistema teórico que lhe era apresentado, gerar por sua vez uma teoria imanente ao sistema. Entrementes, a economia de mercado já está tão questionável que ela zomba de qualquer confrontação desse gênero. A irracionalidade da atual estrutura social impede o seu desdobramento racional em uma teoria. (...). Sob esse aspecto, abdicar dessa teoria não seria um progresso crítico do espírito científico mas sim a expressão de uma forçada resignação. Paralela à regressão da sociedade corre uma regressão do pensamento sobre ela. Adorno, Theodor. "Capitalismo tardio ou sociedade industrial"; p. 66-67.

276 Ibidem. "Introdução à controvérsia"; p. 219-220. 
Entretanto, antes de me dedicar propriamente a análise da relação de Adorno com a sociologia weberiana, será necessária uma breve discussão a respeito da controvérsia com o positivismo alemão.

\section{Crítica ao positivismo.}

$$
\begin{aligned}
& \text { "(...) o que é dito de modo frouxo é mal } \\
& \text { pensado"277 }
\end{aligned}
$$

Realizada em outubro de 1961 em Tübingen, a sessão inaugural da conferência anual da Deutschen Gesellschaft für Soziologie foi o ponto de partida para o que ficaria conhecido posteriormente como Positivismusstreit - controvérsia com o positivismo ${ }^{278}$.

Inicialmente, o debate entre Adorno e Karl Popper organizou-se em torno de uma comunicação principal - a "Lógica das ciências sociais", do filósofo vienense - seguida por um comentário sob responsabilidade do frankfurtiano. Embora essas discussões à época tenham sido avaliadas de maneira negativa pela ausência de uma interação mais substantiva entre os participantes e por seu caráter inconcluso, elas se prolongaram por quase toda a década. De acordo com Hans-Joachim Dahms, houve uma segunda rodada da controvérsia representada pelos ensaios de Jürgen Habermas e de Franz Albert e, por fim, ainda uma terceira etapa marcada pela longa introdução escrita por Adorno em 1968. Tendo em vista os interesses desta pesquisa, será necessário restringir esta minha reconstrução apenas a essas últimas posições do frankfurtiano, deixando de lado um contraste mais acurado com as teses de Popper ou com as dos demais envolvidos e uma interpretação do próprio significado da disputa ${ }^{279}$.

\section{Ibidem. DN; p. 24.}

278 Wiggerhaus afirma que, na verdade, o seu início seria ainda bastante anterior. O autor de A escola de Frankfurt lembra que a crítica ao positivismo já era um tema importante para os frankfurtianos praticamente desde o início de seus trabalhos na década de 1930. Segundo Wiggerhaus: "O que a história das ciências sociais deveria depois resumir sob o título de 'querela do positivismo' remontava aos anos 50. Representava apenas, para Adorno, a continuação do que havia começado nos anos 30 sob a forma de conflito entre o Círculo de Viena e o grupo de Horkheimer, que havia conduzido a organização de discussões entre professores de Frankfurt e de Viena em Frankfurt, Paris e Viena, e tinha sido definido por Horkheimer, no mais famoso de seus artigos, como a oposição entre 'teoria tradicional e teoria crítica'." Wiggershaus, Rolf. A escola de Frankfurt; p. 600. Todavia, acredito que seja mais conveniente seguir com os pressupostos desta pesquisa e dar destaque ao caráter particular dado a elas pelos diferentes autores da teoria crítica e em seus principais momentos.

279 Hans-Joachim Dahms reconstrói de maneira pormenorizada os diversos momentos de tal controvérsia. Embora eu 
Mais do que uma corrente de pensamento específico, o positivismo documentaria um momento particular da história do espírito. Se a grande filosofia expressava de maneira idealista o conteúdo de uma experiência concreta que transcende os sujeitos individuais, ele cristaliza uma forma de regressão da consciência. Peculiar à modernidade tardia, um certo ideal de pureza torna a autoinspeção do sujeito cognoscente o único critério de verdade e de validade científica ${ }^{280}$. Ao fazer vistas grossas para a atuação de uma estrutura social objetiva que precede qualquer prática individual e dá sentido a toda instituição social, o positivismo é levado a crer que seus procedimentos metodológicos fossem criados unicamente pela razão por conta de sua natureza abstrata e, supostamente, neutra.

Porém, além da linearidade da lógica formal não corresponder ao entrelaçamento efetivo dos homens e das coisas, a ilusão acerca da neutralidade do conhecimento em sociologia acompanha a disciplina desde o seu nascimento - sua recorrência, conduto, não lhe torna menos enviesada. A abstração que forja os seus instrumentos não se origina com as experiências científicas, e tampouco dos compêndios de lógica. A sua radical disposição em abstrair a materialidade dos objetos em favor de um conceito que subsuma as idiossincrasias de um caso particular tem por modelo o moderno sistema de produção e de troca de mercadorias. São os seus modos de funcionamento que dotam os sujeitos e as coisas de ares de similitude e, ao mesmo tempo, de um fetiche específico. Fazendo de uma ordinária prática social a sua filosofia de vida, o positivismo enxerga bons motivos para excluir de suas preocupações aquilo que não se enquadre à incoerente rigidez de seus conceitos. Em "Introdução à controvérsia":

divirja de algumas interpretações a respeito do pensamento de Adorno, o autor apresenta todo o contexto histórico e político dessas discussões em seu Positivismusstreit, sobretudo entre as páginas 323-335. Para uma outra interessante reconstrução do clima social e político dessas controvérsia, inclusive com uma interpretação mais atinada ao espírito do texto de Adorno, ver principalmente Müller-Doohm, Stefan. Adorno ; p. 412-420

280 Em DN, Adorno aprofunda essas reflexões por meio de uma caracterização do tipo social do pedante. Segundo Adorno: "Aquilo que, no que há para conceber, escapa à identidade do conceito impele esse último à organização excessiva, de modo que não se levante absolutamente nenhuma dúvida quando à inatacável exaustividade, à completude e à exatidão do produto do pensamento. A grande filosofia foi acompanhada pelo zelo paranoico de não tolerar nada senão ela mesma. O mais mínimo resto de não-identidade era suficiente para desmentir a identidade, totalmente segundo o seu conceito. As excrescências dos sistemas desde a glândula pineal de Descartes e os axiomas e definições de Spinoza, nos quais já está injetado todo o racionalismo que ele extrai posteriormente da maneira dedutiva, manifestam por meio de sua não-verdade a não-verdade dos próprios sistemas, sua loucura." Adorno, Theodor. DN; p. 27. 
O positivismo interioriza as pressões para uma postura espiritual, exercida pela sociedade totalmente socializada sobre o pensamento, no intuito de fazê-lo funcionar nela. Ele é puritanismo do conhecimento. O que este efetua na esfera moral, no positivismo se sublima nas normas do conhecimento. A advertência de Kant, equívoca em sua linguagem, de não se perder em mundos inteligíveis, a cujo respeito Hegel já falava ironicamente das 'casas de perdição', é um prelúdio daquilo; embora somente como voz isolada no tecido polifônico da partitura filosófica, enquanto com os positivistas isto se converteu na melodia da voz dominante trivialmente inoportuna. ${ }^{281}$

Irrefletidamente preso à sua aparência, as sociedades modernas seriam descritas como uma coleção de dados justapostos. Nessa visão estreita em demasia, os conceitos dos positivistas não expressam nada senão o factual. A miopia em relação à sociedade se condensa inclusive nos modos e nas formas de sua linguagem ${ }^{282}$. O seu ideal é por fichas neutras, por meio das quais o cientista expressaria com máxima clareza os predicados associados aos seus objetos. Nessa sua desabrida compulsão por identidade, as suas categorias aplainam apressadamente o que lhes parece disforme. Quando aspectos de determinado fenômeno saltam aos olhos como contraditórios ou mesmo irracionais, o positivismo se enfurna em um trabalho de depuração conceitual enfadonho e sem fim - nada distante da monotonia e da ausência de finalidade da própria sociedade que o produziu.

Todavia, o que é banalizado por aqueles que veem na lógica e em sua imanência poderes sobre-humanos são contradições objetivas, que não podem ser diluídas em pensamento. De acordo com Adorno, o caráter peculiar da relação entre sujeito e objeto neste campo de saber exige um tratamento distinto. A um só tempo, a objetividade social é produto do trabalho humano e algo que se petrifica diante dos indivíduos. Embora seja resultado de processos históricos de interação dos homens entre si e deles com a natureza, as sociedades modernas se enrijecem por conta de suas práticas sociais e obscurecem as formas de consciência subjetiva. Este enviesamento particular das coisas impede que a vida coletiva cumpra a sua verdadeira função. Da antiga promessa de uma

281 Ibidem. "Introdução à controvérsia"; p. 249-250.

282 A esse respeito, segundo Adorno: Segundo Adorno: "O caráter ambíguo da linguagem se expressa na circunstância, em que está de acordo com os positivistas, de adquirir objetividade unicamente mediante a intenção subjetiva. Somente quem expressa da melhor maneira possível o que quer dizer subjetivamente procede de conformidade com a objetividade da linguagem, fortalecendo-a enquanto toda tentativa de se confiar ao ser-em-si da linguagem, bem como à sua essência ontológica, culmina no mau subjetivismo da hipóstase de figuras da linguagem. (...). A negligência estilística de muitos cientificistas, passível de racionalização mediante o tabu a respeito do momento expressivo da linguagem, denuncia uma consciência coisificada. Uma vez que a ciência é dogmaticamente convertida em uma objetividade, que não deve ter passado pelo sujeito, a expressão da linguagem acaba bagatelizada. Quem sempre dispõe estados de coisas como sendo em-si, sem mediação subjetiva, para este a formulação torna-se indiferente, às custas da coisa deificada." Ibidem, idem; p. 223. 
associação de indivíduos livres e racionais, o ordenamento social tardio fez restar apenas o nome. O que deveria ser um meio para garantir a coexistência pacífica e a satisfação das necessidades humanas impõe-se como uma finalidade em si mesma, cujo funcionamento prolonga de maneira sistêmica carências materiais e psíquicas, e leva compulsivamente os indivíduos à violência contra si e contra outrem. Segundo Adorno:

Pois a sociologia possui um caráter duplo: nela o sujeito de todo conhecimento, justamente a sociedade, o portador da universalidade lógica, é simultaneamente objeto. Subjetivamente, a sociedade, por remeter aos homens que a formam, e inclusive seus princípios de organização, remetendo à consciência subjetiva e sua forma de abstração mais universal, a lógica, é algo essencialmente intersubjetiva. Ela é objetiva, porque na base de sua estrutura de apoio, sua própria subjetividade não lhe é transparente, já que não possui um sujeito global e impede a instauração deste em virtude de sua organização. Um tal caráter duplo, porém, altera a relação de um conhecimento científico-social ao seu objeto, e disto o positivismo não toma notícia. ${ }^{283}$

Herdeiro do esclarecimento, o positivismo se apresenta como um discurso alérgico a reflexões teóricas mais adensadas. Traçando apenas uma cópia barata da efetividade social, o positivismo desconhece inclusive as causas de suas convicções mais acertadas e dá uma nova feição à ideologia. Dentro desse quadro, a sociologia é concebida de maneira tacanha. Os fenômenos da vida coletiva são levados ao pé da letra, e as ciências sociais se transformam em um inventário de metodologias aptas a captar a consciência ou a inconsciência média dos indivíduos coagidos por uma totalidade social $^{284}$. Não que os sujeitos pudessem em sua imediaticidade requisitar algum tratamento distinto - a sua identidade não é um produto do acaso. Entretanto, o positivismo não se pergunta pelos motivos de tal disparate e mantém intacta a desordem das coisas. Ele aceita que a atividade intelectual seja entendida e atue unicamente como um princípio abstrato de dominação. Se ela não se treslouca em um espírito criador e absoluto ou em uma paranoia coletiva, nem as suas criaturas e tampouco a sua idolatria foram superadas.

Sob os irracionais ditames da autoconservação das espécies, a instrumentalidade da razão segue seu curso e a vida coletiva permanece como a duplicação incontrolada de uma segunda natureza. Contudo, a coisificação não admite ser tratada como um dado factual e nem se deixa 
interpretar por motivos meramente subjetivos. O seu fundamento deve-se à persistência das sociedades modernas em sua pré-história que garante a unidade do todo social e, ao mesmo tempo, manifesta a sua particular falsidade. Procurando por aquilo que seja uniforme, o positivismo deixa de perceber que a própria identidade tece figurinos apertados e submete os indivíduos à uma vida mutilada. Ponto de partida para o pensamento crítico, os sofrimentos físicos e psíquicos mostram-se como uma experiência universal e objetiva ${ }^{285}$, cuja recorrência cotidiana revela a insofismável negatividade do todo, os momentos nos quais a sua inverdade despreza inclusive as mais persistentes distinções de classe.

Para enfrentar esse estado de coisas, a sociologia não pode não renunciar à distinção entre a essência e a aparência das sociedades modernas. A primeira não é imutável, e tampouco pode ser apontada como algo de uma classe distinta ou superior - o modelo desta atual desmesura das coisas é o logro imanente às trocas de equivalentes. Por seu turno, a sua aparência não é garantia de uma vida melhor ou de uma sociedade mais justa, mas repõe em sua imediaticidade os motivos que levam os homens a agirem como uma massa indistinta. O sujeito pressuposto pela indústria cultural não é uma fantasia criada pelas agências de publicidade, mas é resultado de uma situação de minoridade social da qual os homens não são os culpados e sim as suas vítimas. Segundo Adorno:

A sociedade como sujeito e a sociedade como objeto são a mesma coisa e também não são a mesma coisa. Os atos objetivadores da sociedade eliminam na sociedade o que faz com que não seja apenas objeto, o que lança sua sombra por sobre toda a objetividade cientificista. Reconhecer isto é o mais difícil para uma doutrina cuja norma máxima é a ausência de contraditoriedade. Eis aqui a diferença mais profunda entre uma teoria crítica da sociedade e o que na linguagem corrente é denominado sociologia: uma teoria crítica, apesar de toda experiência de coisificação, e mesmo justamente ao exteriorizar esta experiência, se orienta pela idéia de uma sociedade como sujeito, enquanto a sociologia aceita a coisificação, repetindo-a em seus métodos, perdendo assim a perspectiva em que a sociedade e sua lei unicamente se revelaram. ${ }^{286}$

Porém, as sociedades modernas expõem fissuras em quaisquer dos seus momentos, e

285 Em DN: "(...) de fato, há uma experiência espiritual em verdade falível, mas imediata do essencial e do inessencial, uma experiência da qual a necessidade científica de ordem não pode dissuadir os sujeitos senão pela força. Onde quer que uma tal experiência não seja feita, o conhecimento permanece imóvel e infrutífero. Ela encontra a sua medida naquilo que se passa objetivamente aos sujeitos como o seu sofrimento. Paralelamente ao nivelamento teórico da essência e da aparência, os sujeitos cognoscentes também perdem com certeza subjetivamente, junto com a sua capacidade para o sofrimento e para a felicidade, a faculdade primária de separar o essencial do inessencial, sem que se saiba aí corretamente o que é causa e o que é consequência." Ibidem. DN; p. 147.

286 Ibidem. "Introdução à controvérsia"; p. 233. 
sobretudo em seus aspectos mais sutis. Como uma mônada, cada evento singular expressa em suas minúcias o caráter contraditório do todo. Para o frankfurtiano, a visada micrológica faria mais justiça à empiria do que os procedimentos cientificistas tradicionais. O modo pelo qual o universal se lança sobre aquilo que seja particular ignora qualquer diferença e apaga as marcas histórico-sociais de seus procedimentos - o traço qualitativo das coisas é eliminado em favor de uma unidade abstrata. Os dados imediatos da realidade empírica e a estrutura da vida psíquica são forjados em moldes similares. Contudo, esta forma social não consegue cumprir integralmente os seus próprios critérios ou requisitos e nem corresponder aos anseios de quem quer que seja. Nos pormenores de qualquer objeto manifesta-se uma experiência de alteridade não subsumível às regras de tal formalismo.

No âmbito da produção de riquezas materiais, os valores de uso resistem ao seu papel de meros portadores de valores de troca como um objeto que possui ainda outras funções. Por mais que as recorrentes trocas de mercadorias tente convencer do contrário, não nada há inscrito na natureza das coisas que as façam serem mensuradas consoante o tempo médio de trabalho abstrato socialmente necessário. No campo da ciência, o quid pro quo é ainda o mesmo. Ao tentar esgotar por definições conceituais a singularidade de um fenômeno concreto, projeta-se na empiria os estritos critérios de uma racionalidade instrumental. Alimentada pela corrente separação entre o trabalho manual e o intelectual, a razão resigna-se ao papel de um mecanismo de coordenação da matéria tida como amorfa. Embora menosprezado pelas correntes hegemônicas de pensamento, o que diverge da norma é desencadeado pela imanência de sua lógica.

A crítica sociológica deve se ater demoradamente ao proscrito como inessencial e episódico, e preservar em suas categorias essa peculiar experiência de tensão. Diferentemente de uma certa sociologia do conhecimento, a função social do pensamento ou a simples revelação dos interesses socioeconômicos que o condicionam não podem ser os seus únicos critérios de verdade. Transformada em uma espécie de engenharia social, a dominação da natureza não disfarça a sua 
incontida proximidade com uma sociedade de classes ${ }^{287}$. Como consciência consequente da não-identidade, a dialética não procura pela unidade, mas orienta a sua crítica pela corrente inadequação entre os conceitos e as coisas. Ela expressa uma inquietude característica que nem mesmo o brilho reluzente das fórmulas da indústria cultural silencia - a contradição fundamental que articula a vida social constitui o cerne do próprio conceito de sociedade ${ }^{288}$. Segundo Adorno:

O não inteiramente literal testemunha a tensa não identidade de essência e fenômeno. O conhecimento enfático não cai no irracionalismo quando não se desliga da arte de modo absoluto. A adulta gozação cientificista acerca da 'música dos pensamentos' apenas suplanta o ranger das portas das estantes em que são guardados os questionários, os ruídos do empreendimento de literalidade pura. Associa-se à experiente objeção ao solipsismo de um pensamento auto-satisfatório acerca da sociedade, que nem respeita o estado de coisas daquela, nem preenche nela uma função útil. ${ }^{289}$

Ciente da natureza de tais dissonâncias, a reflexão dialética lavra sua via por outros caminhos e se agarra a pretensões distintas. Crítica do coetâneo quadro de divisão dos saberes em especialidades científicas, ela se espraia em busca da totalidade de seu objeto. Ainda que o ideal sistêmico da aurora do capitalismo liberal já tivesse sido descortinado como uma ilusão ideológica, a objetividade social ainda se impõe sobre todos os momentos da vida individual e coletiva. A sua onipresença não se realiza de maneira translúcida e nem por meio de uma dinâmica pacífica ou bem orientada. Ademais, o que é realmente objetivo na sociedade não se reduz a um dado factual. Mais do que assunto de uma ciência particular, a sociedade é uma categoria de mediação ${ }^{290}$.

287 A esse respeito, em DN: "A sociologia do saber, por outro lado, nega tanto a estrutura objetiva da sociedade quanto a ideia de uma verdade objetiva e de seu conhecimento. Para ela, exatamente como para o modelo da economia positivista à qual Pareto pertencia como seu fundados, a sociedade não é outra coisa senão o valor mediano dos modos de reação individuais. Ela reconecta a doutrina da ideologia a uma doutrina subjetiva dos ídolos, à moda das primeiras doutrinas burguesas; trata-se aí certamente de um artifício de advogado que procura se desembaraçar com a filosofia como um todo da dialética materialista. O espírito tel quel é localizado de maneira classificatória. Uma tal redução das assim chamadas formas de consciência é certamente compatível com a apologética filosófica. Sem ser perturbada, a sociologia do saber conserva a via de escape de pretender que a verdade ou a não-verdade daquele que é filosoficamente erudito não tenha nada em comum com as condições sociais; o relativismo e a divisão do trabalho são complementares." Ibidem. DN; p. 169.

288 A esse respeito, segundo Schweppenhäuser: "A essência da sociedade moderna, que se revela e se oculta ao mesmo tempo, é uma má essência [Unwesen]. Essa compreensão tem um significado não só descritivo, mas também normativo. A essência não é uma entidade metafísica, e sim uma abstração existente [daisende]. E é, por constituir a essência da sociedade, o falso: de fato, aquilo que impede a realização do ser genérico do homem. A teoria social de Adorno quer submeter à crítica a compulsão pela identidade [Identitätszwang], considerando-a como uma má essência, a fim de mostrar que uma identidade livre de coerções, tanto do lado da sociedade quanto do lado dos indivíduos, é algo que ainda se haveria de se concretizar como necessidade." Schweppenhäuser, Gerhard. Theodor W. Adorno zu Einführung; p. 73.

289 Adorno, Theodor. "Introdução à controvérsia"; p. 234.

290 Ibidem. Introdução à sociologia; p. 249. 
Para fazer frente à peculiaridade desse seu objeto, a dialética deve absorver o conteúdo da experiência histórica de onde provêm. Se Hegel sucumbiu à lógica da identidade ${ }^{291}$, a dissolução de seu sistema permite que ela perca as suas feições dogmáticas e exige que abandone as suas ilusões idealistas. Não se trata de pensá-la como simples reflexo de relações materiais mais essenciais. Nada há de novo quando o materialismo imagina encontrar um chão firme no irrefletido desdobramento da matéria bruta. Conquanto possua incontornável origem social, o espírito que anima o mundo moderno não pode prescindir de uma contraparte subjetiva. Sublimada em um tipo específico de razão, a forma da objetividade social configura a consciência humana e adentra as suas camadas psíquicas mais profundas - uma certa disposição diante das coisas se torna racional para esses indivíduos. Posta em prática por seus membros, a imanência de tal racionalidade desfigura a vida dos homens concretos e subverte a impessoalidade de suas regras em favor da manutenção do status quo.

Todavia, é justamente esse sujeito o locus de uma reação possível - somente ele consegue fugir das garras da reificação. Ainda que em sua imediaticidade a razão atue como um instrumento que conduz a uma desumanidade crescente, ela é também o órgão humano que permite ir além da mera adaptação ao existente. A intransigência da crítica diante do factual libera o pensamento de suas funções de autoconservação. Nesses seus momentos, as suas feições subjetivas não são simples peças de uma ipseidade individual, mas a condição fundamental de um saber eminentemente crítico. Segundo Adorno:

\footnotetext{
Quanto mais estritamente esta se adapta aos estados de coisa, tanto mais se distancia da mera significação e adota algo parecido à expressão. Que a controvérsia do positivismo tenha até agora permanecido infrutífera, deve-se também em parte a que os conhecimentos dialéticos são tomados de modo excessivamente literal por parte de seus opositores; literalidade e precisão não significam o mesmo, antes são divergentes. Sem ruptura, e
}

291 Embora ultrapasse os limites desta pesquisa, é interessante citar uma crítica de Adorno a Hegel, em DN Segundo Adorno: "Na primeira observação à primeira tríade da lógica, Hegel recusa-se a começar com o algo em vez com o ser (...). Com isso, ele prejudica toda a obra que quer evidenciar o primado do sujeito no sentido deste último, i.e., de maneira idealista. Só muito dificilmente a dialética se desenvolveria nele de outra forma se, como corresponderia ao traço fundamental aristotélico da obra, ele tivesse partido do algo abstrato. Por mais que a representação de um tal algo enquanto tal possa mostra mais tolerância ante o não-idêntico do que a representação do ser, ela não é de maneira alguma menos mediatizada. Não se poderia tampouco permanecer parado junto ao conceito do algo. Sua análise precisaria continuar se movimentando em direção àquilo que ele pensa: na direção do não-conceitual". Ibidem. DN; p. 119. 
impropriedade, não existe conhecimento que seja mais do que repetição ordenadora. $\mathrm{O}$ fato de que ao mesmo tempo não sacrifica a idéia de verdade, tal como seria muito mais de acordo com o positivismo conforme seus representantes mais conseqüentes, circunscreve uma contradição essencial: o conhecimento, e isto de maneira alguma ocorre per accidens, constitui um exagero. Pois tão pouco como algo singular é 'verdadeiro', mas, graças à sua mediação, também forma seu próprio outro, assim também o todo não é verdadeiro. Sua permanência como inconciliável com o singular constitui expressão de sua própria negatividade. ${ }^{292}$

\section{As constelações e os tipos ideias.}

$$
\text { “Exagerar é a minha profissão.” }
$$

Além de antecipar argumentos importantes para a interpretação do pensamento tardio de Adorno, a reconstrução de aspectos desse embate com o positivismo alemão serve como um pano de fundo a partir do qual se pode contextualizar a abordagem do frankfurtiano a alguns elementos da sociologia weberiana. Não obstante, embora o autor de $\mathbf{D N}$ estabeleça linhas de continuidade entre Popper e Weber, o seu diálogo com este último é naturalmente mais intrincado e, além disso, suscita questões de um outro estatuto.

Para trazê-las ao lume, será preciso interpelar principalmente os juízos de Adorno a respeito do conceito de tipo ideal. Ainda que fosse pensado segundo uma concepção tradicional e subjetivista de ciência, a composição rigorosa desse instrumento analítico é tomada na mais alta conta. É certo que as bases pelas quais Weber assentava a validade dessas suas construções estavam como que viradas do avesso, ao menos segundo o materialismo do frankfurtiano. Todavia, ao se chocar com os limites de seus preceitos metodológicos, a sociologia weberiana consegue ultrapassar a estreiteza daqueles e o modo de funcionamento de seus tipos ideais é alçado a modelo da reflexão dialética. Isso, por um lado.

Por outro, não se pode ignorar a discussão de Adorno acerca do significado desses entraves na teoria social weberiana. Novamente, o peso de suas análises o distinguiria dos positivistas. Porém, o frankfurtiano se opõe fortemente ao entendimento de Weber do papel e das aspirações do conhecimento e da reflexão sociológica, à sua compreensão a respeito do processo de 
racionalização social e, como síntese, da própria natureza das sociedades modernas ${ }^{293}$. Tais considerações não devem ser lidas em um nível mais imediato, como se fossem divergências pontuais entre os autores, pois elas se articulam em torno de uma teoria social. Se crítica do conhecimento é crítica da sociedade, a sociologia depara-se com o seu objeto até mesmo em suas formulações mais abstratas - sobretudo, quando ela se ocupou com tanta agudeza das vicissitudes de suas tramas de composição conceitual. Em Introdução à sociologia:

Quando nos dedicamos seriamente a Weber, as coisas são muito mais difíceis do que parecem à primeira vista, o que talvez sirva para estimular o seu estudo. Gostaria de empregar em relação a Weber o que eu afirmei certa vez em relação a Thomas Mann: que em seu caso o decisivo é o que não está no mapa, ou seja, aquelas coisas que contrariam a sua própria metodologia oficial. Quando estudamos os escritos de Weber, que vem da escola histórica da economia política como discípulo de Gustav von Schmoller e que depois insistiu na independência da Sociologia na Alemanha da mesma forma que Durkheim o fez na França (então percebemos) que ele deve todo conteúdo de seus trabalhos ao material histórico. ${ }^{294}$

Entretanto, convém voltar antes a Weber e, por mais uma vez, será preciso retornar a certos aspectos metodológicos de seu pensamento. Em A “objetividade” do conhecimento das ciências sociais (doravante, A “objetividade”), o sociólogo de Heidelberg expõe uma requintada elaboração sobre os critérios de validade desse tipo particular de saber e os instrumentos conceituais próprios ao trabalho de sua ciência e, no entremeio, apresenta uma densa e pormenorizada reflexão sobre a natureza das sociedades modernas. Consequência esperada de um autor que orientava esse tipo de questionamento, se seguirmos Gabriel Cohn, principalmente a partir de problemas concretos associados ao cotidiano de sua atividade intelectual ${ }^{295}$. Não é o caso, evidentemente, de especular acerca de seu interesse e de sua pertinácia consoante um viés pragmático. Mas de ressaltar a particularidade de um autor cujas considerações metodológicas foram tecidas no trato direto com o

293 Em "A physiognomy of the capitalist form of life: a sketch of Adorno's social theory", Honneth chama atenção para as similitudes entre Adorno e Weber, sobretudo quando se compara as dicussões metodológicas do frankfurtiano com o A "objetividade" de Weber. A minha interpretação é completamente distinta. Embora a noção de tipo ideal de Weber seja absolutamente central para a compreensão do pensamento de Adorno, é necessário se atentar sobretudo para as suas divergências com essa sociologia no exame da apropriação particular que o frankfurtiano faz dos tipos sociais de Weber.

294 Adorno, Theodor. Introdução à sociologia; p. 279-280.

295 A esse respeito, segundo Gabriel Cohn, ao tratar da peculiaridade da apropriação de certas ideias de Windelband e Rickert em Weber: "De modo geral e independentemente do confronto mais pormenorizado, pode-se assinalar desde logo que naquilo que Max Weber incorporou das formulações desses autores, há uma decisiva mudança de ênfase, no sentido de que sua preocupação primordial é com considerações de ordem estritamente metodológicas. Sua perspectiva, em suma, é a do cientista prático, mais do que a do filósofo.” Cohn, Gabriel. Crítica e resignação; p. 99. 
objeto de sua ciência, e não formuladas unicamente segundo uma abordagem filosófica estrita.

Nesse sentido, é certo que para Weber a relação entre a esfera conceitual e a realidade empírica seria marcada por uma cisão intransponível. Porém, o fundamento que permite à sociologia se apropriar de fenômenos da ordem social assenta-se, ele mesmo, na especificidade da vida em sociedade. A peculiaridade deste tipo de saber remete ao fato de que os homens são seres dotados de cultura e, portanto, estabelecem entre si vínculos portadores de significados. Essa realidade sui generis pode ser compreendida somente porque - e antes - os indivíduos agem socialmente animados por inúmeras concepções de mundo e por conjuntos de ideais radicalmente distintos entre $\mathrm{si}^{296}$. Ao perscrutar os seus efeitos e os seus condicionamentos sobre as condutas subjetivas, a sociologia persegue os caminhos da ciência ao contrastar os objetivos visados pelos agentes com os meios históricos disponíveis em cada situação específica. A exigência de ausência de contradições lógicas em suas elaborações teóricas é partilhada com as demais áreas do conhecimento racional. No entanto, a observação a respeito do caráter axiologicamente neutro de suas investigações é mais urgente e particular.

Não que a questão dos valores lhe seja indiferente - antes, o contrário. Se sobretudo a sociologia não pode alimentar volições normativas é porque já de início ela os tem como legítimos objetos de suas preocupações ${ }^{297}$. Em vez de se contaminar por qualquer valoração arbitrária, a sociologia deve se voltar para a compreensão da manutenção de certas linhas de continuidade no interior das relações sociais e das formas do agir humano. Embora o universo de valores estabeleça vínculos fluídos e por vezes tênues com o campo das interações e das práticas sociais, ele ainda assim é capaz de imprimir certos padrões de regularidade nas ações subjetivas e, com isso, torna possível o reconhecimento de encadeamentos causais no âmbito dos fenômenos da vida em sociedade. Vistos consoante recursos metodológicos adequados, os eventos próprios ao mundo

\section{Weber, Max. A "objetividade"; p. 20.}

297 A esse respeito, segundo Weber: "Qual é a conseqüência dessa afirmação? De modo algum que os juízos de valor, por se basearem em última instância em determinados ideais e portanto terem origem 'subjetiva', estejam excluídos da discussão científica. Isso seria desmentido seguidamente pela prática e o objetivo da nossa revista. A crítica não se detém diante dos juízos de valor. A questão é: que significa e o que pretende a crítica científica de ideias e juízos de valor? Ela merece um exame um pouco mais demorado.”. Ibidem, idem; p. 15. 
social são apreendidos de modo a que reivindiquem também para um chinês - ciente dos pressupostos do pensamento racional ocidental - a validade de uma ordenação mental composta por meio da investigação sociológica de determinada realidade empírica ${ }^{298}$. Em A “objetividade”:

A ciência social que nós pretendemos praticar é uma ciência da realidade. Procuramos compreender a realidade da vida que nos rodeia, e na qual nos encontramos situados, naquilo que tem de específico; por um lado, as conexões e a significação cultural de suas diversas manifestações em sua configuração atual e, por outro, as causas pelas quais se desenvolveu historicamente assim e não de outro modo. ${ }^{299}$

Contudo, a objetividade desse tipo de conhecimento será incontornavelmente problemática. Se alguma ética religiosa de um passado recente deu mostras de se efetivar com uma coerência lógica quase matemática e pretendeu abarcar os diversos momentos das vidas de seus seguidores, nem ela e menos ainda os conceitos das ciências da cultura possuem de forma inerente qualquer substancialidade empírica ou social. Caso já não fosse ocioso lembrar mais uma vez, de acordo com Weber, o mundo social moderno é marcado tanto no plano individual como em âmbito coletivo pelo famigerado politeísmo de valores. Mesmo quando se nota uma altíssima afinidade entre posições políticas ou gostos estéticos e os modernos interesses de classe, a correlação será tão somente provável e sempre derivada de uma atribuição exterior de sentido ${ }^{300}$. No limite e em qualquer de seus momentos, a razão da vigência de certos ideais e de determinados valores e não de todos os demais depende do sucesso - ou do fracasso - de relações de dominação. Estas podem se legitimar ante os indivíduos das formas mais distintas e nos graus mais variáveis. De toda maneira, haverá sempre resíduos de arbitrariedades nesses arranjos sobre os quais a sociologia não pode intervir com nenhum direito ou propriedade.

Ao ser disciplinada como uma ciência empírica, a sociologia apenas visa repisar no plano conceitual as condições com as quais os homens se defrontam em suas vidas cotidianas. Os cientistas que provaram efetivamente dos frutos da árvore do conhecimento sabem que já não se trata mais de um tempo no qual algum imperativo ético possa pleitear qualquer espécie de validade

298 Ibidem, idem; p.; 24 
incondicional e objetiva. Aquilo que mais nos comove e nos impele à ação não se impõe sobre todas as nossas outras vontades ou sobre os anseios do restante da população mediante argumentos materialmente racionais, ou a partir de simples considerações de ordem técnica. Seja no interior de nossa personalidade, seja nos mais diversos âmbitos da vida coletiva, o que se estabelece como um valor ou como uma norma ética o faz necessariamente por meio do confronto e da luta, cujo resultado nunca será justo ou imutável e, apenas em raríssimos casos, aparentemente unívoco.

Dessa perene turbulência do mundo sociocultural, o cientista consegue abarcar com seus conceitos somente aspectos parciais desse todo sempre arredio a qualquer categorização incontroversa que é a própria sociedade moderna. Tal como qualquer outro indivíduo, o cientista também é premido por ideais e por interesses que se articulam - bem ou mal, com maior ou menor poder de coerção sobre a sua conduta - em torno de um conjunto de valores ou mesmo de uma ética de vida. A atividade científica jamais estará isenta de pressupostos desse tipo. Não obstante, na medida em que se abandone a pretensão de ensinar a alguém sobre aquilo que se deva e se limite à inquirição sobre o que se pode ou sobre o que se quer fazer, as suas reflexões teóricas são capazes desviar-se dos descaminhos que continuarão sempre a lhes espreitar. O rigor metodológico preserva o trabalho intelectual de extrapolar os seus limites. Nesse momento, a sociologia retira-se do universo das crenças e, verdadeiramente, ela adentra no da ciência. Segundo Weber:

O conceito de cultura é um conceito de valor. A realidade empírica é “cultura” para nós porque, e na medida em que, nós a relacionamos a idéias de valor. Ela abrange aqueles e somente aqueles componentes da realidade que, por meio dessa relação, tornam-se significativos para nós. Uma parcela ínfima da realidade individual que observamos em cada caso é matizada pela ação de nosso interesse condicionado por essas idéias de valor; somente ela tem significado para nós precisamente porque revela relações tornadas importantes graças à sua vinculação a idéias de valor. É somente por isso, e na medida em que isso ocorre, que nos interessa conhecer sua característica individual. Entretanto, o que para nós se reveste de significação naturalmente não poderá ser deduzido de um estudo "isento de pressupostos” do empiricamente dado; ao contrário, é a comprovação dessa significação que constitui a premissa para que algo se converta em objeto de análise. ${ }^{301}$

Para fazer frente a um desafio dessa magnitude, a psicologia individual não demonstrava ter grande utilidade para Weber ${ }^{302}$. Essa ciência da psique humana partilharia ainda dos desenganos de

301 Ibidem, idem; págs. 50-51.

302 Embora não seja possível me dedicar a essa questão, desde já é importante ressaltar que investigar o diálogo de Weber com a psicanálise de Freud parece não se circunscrever a esses parâmetros. A esse respeito, Flavio Pierucci 
uma injustificada ingenuidade. No que tange à análise dos motivos da ação individual, ela supõe ser plausível decompor as complexas conexões que entrelaçam os fenômenos envoltos na coexistência intersubjetiva a fatores psicológicos simples e regulares. Tal qual investigações de cunho antropológico cuja pretensão se esgota na descrição de supostas qualidades raciais inatas como fundamento de algum processo histórico, a relevância dessa psicologia para o conhecimento social é, quando muito, bastante lateral. Em vez de um trabalho metodológico zeloso, o que se oferece é uma grosseira abstração. Elege-se modos ordinários de reação como princípios essenciais da conduta humana, perdendo assim não só a capacidade de compreender o caráter concreto da atribuição de significado a uma forma particular de comportamento subjetivo como também o próprio motivo de existência deste tipo especial de saber - ela faz da legítima aspiração por um conhecimento racional da realidade sócio-histórica um insosso produto da moderna febre de instaurar ciências ${ }^{303}$.

Na verdade, a própria matéria social impele a uma abordagem de outra espécie. Se o que realmente importa é se apropriar conceitualmente do que seja o característico em um dado fenômeno social, a sociologia tem de se haver com uma realidade muito mais fugidia. No plano dos agentes, ela necessita distinguir entre a miríade de práticas e de condutas individuais aquelas que cumprem, com propriedade, os requisitos de uma ação em sociedade. Nem todos os acontecimentos banais ou importantes na vida dos indivíduos são suscetíveis a essa categorização, o choque

chama atenção para o uso do do neologismo ab-reação (Abreagiren), cunhado por Freud, na redação de sua Ética protestante. Embora eu desconheça um trabalho de fôlego a respeito das relações entre Weber e Freud, muito comentadores já sublinharam indicações intrigantes. Destaco a indicação feita por Gabriel Cohn sobre a confluência entre as ideias de Weber e as de Freud em $\mathbf{A}$ interpretação dos sonhos, em seu Crítica e resignação.De todo modo, é importante apenas destacar esse critério de delimitação em seu pensamento com relação à distinção entre sociologia e psicologia. Embora eu desconheça um trabalho de fôlego a respeito No capítulo "Conceitos sociológicos fundamentais" de ES: "Mas, em termos gerais, as relações que a Sociologia tem com a Psicologia não são mais íntimas do que as que tem com todas as outras ciências. O erro está no conceito do 'psíquico': tudo o que não é 'físico' seria 'psíquico'. Mas, certamente, não é coisa 'psíquica' no sentido de um exemplo aritmético que alguém tenha em mente. A consideração racional de uma pessoa sobre se determinada ação é proveitosa ou não para determinados interesses dados, em vista das conseqüências a serem esperadas, e a decisão resultante são coisas cuja compreensão nem por um fio é facilitada por considerações psicológicas. Mas é precisamente em tais pressupostos racionais que a Sociologia (incluída a Economia) fundamenta a maioria de suas 'leis'. Na explicação sociológica dos aspectos irracionais das ações, ao contrário, a Psicologia Compreensiva pode prestar, sem dúvida, serviços de importância decisiva." Ibidem. ES; p. 12.

303 Ibidem. A "objetividade"; p. 40. 
ocasional entre dois ciclistas assemelha-se mais a um fenômeno de ordem natural do que a algo

pertencente ao mundo sociocultural.

Como se sabe, o desenlace posterior dessa situação hipotética apenas se torna digno de uma problematização sociológica quando os agentes envolvidos nessa interação orientam as suas ações visando a um sentido subjetivo qualquer. Nem a simples influência de algum evento sobre o comportamento imediato de um ou de vários indivíduos e tampouco a homogeneidade de suas condutas são critérios suficientes. A sua definição se torna menos segura na medida em que a ação social seja afetiva ou tradicional, e mais clara quando se trata de um tipo racional. Porém, tanto nas situações fronteiriças quanto nas menos controversas, componentes compreensíveis se entrelaçam e se misturam a inúmeros outros fatores não interpretáveis consoante esses parâmetros ${ }^{304}$. Aquilo que não se enquadre em uma equação entre meios e fins de uma ação social não faz parte das preocupações da sociologia. Cabe ao cientista se haver com os dessabores de sua atividade intelectual, e voltar-se exclusivamente aos legítimos objetos de sua ciência. Segundo Weber:

O que nos interessa na conduta do homem, dentro do âmbito das suas relações sociais, é especificamente particularizado segundo a significação cultural específica da relação em causa. Trata-se de causas e influências psíquicas, extremamente heterogêneas entre si e extremamente concretas na sua composição. A investigação sociopsicológica significa um exame aprofundado dos diversos gêneros particulares e díspares de elementos culturais, tendo em vista sua acessibilidade para nossa revivência compreensiva. Partindo do conhecimento das instituições particulares, esse exame nos permitirá compreender intelectualmente e em medida crescente seu condicionamento e significação culturais, mas não nos ajudará a explicar as instituições a partir de leis psicológicas ou de fenômenos psicológicos elementares. ${ }^{305}$

304 Ibidem. ES; p. 4. Para o contraste posterior com Adorno, é interessante lembrar que Weber não concebia a reprodução de uma ação como um movimento de massas em critério suficiente para a classificação enquanto ação social. A esse respeito, segundo Weber: "Uma ação que, em seu curso, se determina ou se co-determina, de maneira apenas reativa, pelo simples fato de haver uma situação de 'massa', sem que haja uma relação de sentido com essa situação, não seria uma 'ação social' no sentido aqui adotado do termo. A distinção, entretanto, é naturalmente muito fluida. Pois não apenas na pessoa do demagogo, por exemplo, mas também na massa do público pode existir, em grau diferente e suscetível a diversas interpretações, uma relação de sentido com a situação de 'massa'. Além disso, a simples 'imitação' da ação de outra pessoa (cuja importância, com toda a razão, foi ressaltada por G. Tarde) não pode ser considerada uma ação especificamente 'social' quando é puramente reativa, sem orientação da ação própria pela alheia quando ao sentido. Nesse caso o limite é tão fluido que muitas vezes a distinção parece impossível. Mas o simples fato de alguém adotar para si determinado comportamento observado em outras pessoas e que lhe parece conveniente para seus fins não é ação social em nosso sentido. Pois nesse caso o agente não orienta sua ação pelo comportamento de outros, mas, a observação desse comportamento permitiu-lhe conhecer determinadas probabilidades objetivas, e é por estas que orienta sua ação. Sua ação está determinada causalmente pela de outra pessoa e não pelo sentido inerente àquela. Quando, ao contrário, se imita, por exemplo, um comportamento alheio porque está 'na moda', porque é considerado tradicional, exemplar ou 'distinto' com respeito a determinada classe social, ou por outros motivos semelhantes, então existe uma relação com sentido - seja referente ao comportamento da pessoa imitada, de terceiros ou de ambos." Ibidem, idem; págs. 14-15.

305 Ibidem. A “objetividade”; págs. 70-71. 
Atenta a esse conjunto de elementos, a sociologia estende os seus conceitos a seres e a objetos inanimados, ou ainda a processos supraindividuais e a fenômenos coletivos. Um artefato ou uma instituição tornam-se compreensíveis na medida em que se possa inquerir sobre os termos da finalidade para a qual os homens pretenderam produzi-los e utilizá-los. As suas eventuais funções não lhes são objetivamente inerentes, e tampouco esgotam os diversos efeitos desencadeados ou todos os resultados possíveis. O caráter socioeconômico que, por ventura, se associa a uma instituição ou a um acontecimento específico permanece necessariamente atrelado a eles por ideias de valor. Independentemente da espécie e do grau dessa relação, os motivos econômicos - ou os culturais, ou os políticos, ou quaisquer que sejam - não são capazes de deduzir integralmente a realidade empírica. Estabelecidas exclusivamente a partir da disposição pela qual os homens orientam as suas condutas, as feições assumidas por esses fenômenos são sujeitas a desaparecerem completamente, a assumirem outros significados e, até mesmo, a permanecer - aparentemente ou não - intocadas durante décadas.

As ciências sociais lidam, portanto, com a fluidez de uma realidade radicalmente histórica a peculiar infinitude de seus objetos as dotam do viço de uma jovialidade eterna. De acordo com Weber, os seus conceitos teriam que absorver internamente o caráter sempre mutável de seus fenômenos. Inicialmente, a exigência é literal e um tanto evidente. Como o cientista não consegue controlar os inumeráveis fatores que influem - ou deixam de influir - sobre as ações e as relações sociais, os seus tipos ideias necessitam ser reavaliados de forma recorrente. A todo momento, o terreno movediço sobre o qual se mantém as sociedades redesenha-se em novas configurações. Além de parcial, o conhecimento sociológico terá sempre de se justificar ante essas transformações da empiria. A continuada problematização conceitual dilata os prazos de validade dos tipos ideais. Sem esse demorado trabalho de reflexão teórico-conceitual, a sociologia jamais poderá dar conta da concretude de seus objetos.

Ademais, o próprio recorte operado na realidade é histórica e culturalmente condicionado. A 
velha questão dos valores desempenha aqui um papel distinto. Já não se trata apenas da advertência em prol do respeito aos limites acadêmicos de uma ciência empírica. O problema tampouco se associa exclusivamente à condicionalidade específica a este tipo de conhecimento. Por conta da origem e das formas de atuação de seus fenômenos, a sociologia dispõe de bases unicamente subjetivas para assentar as suas formulações. Ante um universo indeterminável e multifacetado, a razão para se destacar algum fragmento particular de um dado evento social não deriva de nada que lhe seja objetivo. Pelo contrário, são os pressupostos valorativos trazidos pelo pesquisador que conferem uma direção ao seu trabalho ${ }^{306}$. Tanto a escolha de campos temáticos quanto a definição prévia daquilo que seja importante ou secundário na compreensão de um fenômeno se mantêm atreladas a essas mesmas premissas. As interpretações sociológicas devem acompanhar os passos de seus objetos, porém este nunca sucumbirá a uma definição pretensamente exaustiva - a sociologia jamais encontrará solo firme sobre o qual estruture uma teoria objetiva. Segundo Weber:

O fluxo do devir incomensurável flui incessantemente ao encontro da eternidade. Os problemas culturais que fazem mover a humanidade renascem a cada instante e sob um aspecto diferente, e permanece variável o âmbito daquilo que, no fluxo eternamente infinito do individual, adquire para nós importância e significação, convertendo-se em 'individualidade histórica'. Mudam também as relações intelectuais sob as quais são estudados e cientificamente compreendidos. Por conseguinte, os pontos de partida das ciências da cultura continuarão a ser variáveis no imenso futuro, enquanto uma espécie de imobilidade chinesa da vida espiritual não desacostumar a humanidade de fazer perguntas à sempre inesgotável vida. ${ }^{307}$

Para se orientar diante dessa realidade inesgotável, o pesquisador não deve abrir mão de saber mais abstrato e formulado com ambições nomológicas. Ao menos durante uma etapa da reflexão o acesso a dados socioeconômicos mais gerais, a informações sobre densidade populacional, de taxas de natalidade, etc. podem ser úteis para a composição de certos tipos ideais.

De toda forma, esse tipo de conhecimento não é o único possível em matéria de sociedade. Na linha de frente e certamente coberto de maior interesse, o saber sociológico deve se guiar ao encontro de problemas mais concretos. Diferentemente das ciências da natureza, a elaboração conceitual em ciências da cultura não aspira pela descoberta de leis objetivas ou de regularidades

306 Ibidem, idem; p. 60.

307 Ibidem, idem; págs. 63-64. 
imutáveis e abstratas. Compostos ao longo dos diversos momentos de uma pesquisa, os seus conceitos buscam pelo significado particular associado a um fenômeno específico. Categorias genéricas ou muito abrangentes não conseguem captar em detalhes a peculiaridade do material empírico. Ao se aproximar do que seria comum a um numeroso conjunto de eventos, a sociologia se afasta daquilo que particulariza os seus objetos. O saldo se resume a um agregado de formulações vazias produzidas por um conhecimento abstrato e, igualmente, pobre em conteúdo ${ }^{308}$ - nada distantes dos achados daquela psicologia de matriz biológica.

Ainda que o pesquisador parta para uma análise comparativa entre as éticas econômicas das religiões mundiais, ele terá sempre em mente o que seja particular a uma determinada individualidade histórica. Se é possível compará-las segundo critérios de racionalidade, os mesmos foram compostos consoante o que é valorizado dentro de um contexto sociocultural específico. A sociologia precisa se manter atenta às minúcias de seus objetos, e um saber como este não pode aspirar a nenhuma universalidade. A reunião posterior da infinitude das diversas perspectivas nunca conseguirá recompor a totalidade de um fenômeno social qualquer. Ao se voltar para aquilo que seja o característico, a composição dos tipos ideais implica em problematizar relações muito mais concretas e particulares. Segundo Weber:

Quanto se trata da individualidade de um fenômeno, o problema da causalidade não incide sobre leis, mas sobre conexões causais concretas; não se trata de saber a que fórmula se deve subordinar o fenômeno a título de exemplar, mas sim a que constelação particular deve ser imputado como resultado. Trata-se, portanto, de um problema de imputação. Onde quer que se trata de explicação causal de um "fenômeno cultural" - ou de uma “individualidade histórica”, expressão já utilizada relativamente à metodologia da nossa disciplina, e agora habitual na lógica, com uma formulação mais precisa -, o conhecimento das leis da causalidade não poderá constituir o fim, mas antes o meio do estudo. Ele facilita e possibilita a imputação causal dos elementos dos fenômenos, tornados importantes para a cultura por sua individualidade, às suas causas concretas. É apenas na medida em que presta esse serviço que poderá ter valor para o conhecimento das conexões individuais. E quanto mais "gerais", isto é, abstratas, são as leis, que menos contribuem para as necessidades da imputação causal dos fenômenos individuais e, indiretamente, para a compreensão da significação dos acontecimentos culturais. ${ }^{309}$

Tal composição lavra-se pelo exagero. Não há na realidade histórica nenhum conjunto de valores ou de princípios éticos que se articule em um nível de sistematicidade útil à sociologia. Se

308 Ibidem, idem; p. 57.

309 Ibidem, idem; págs. 54-55. 
alguma doutrina religiosa quase desempenhou por si um papel semelhante, o que interessa ao cientista é necessariamente distinto daquilo que anima os fieis. Além de reunir de forma sistêmica um conjunto limitado de elementos parciais de uma determinada ética de vida, há uma inevitável mudança de ponto de vista. Ao cientista não é permitido advogar por visões de mundo, e o constructo teórico possui apenas funções heurísticas. Quando o calvinismo fora pensado a partir dos efeitos que os seus dogmas teriam sobre a conduta prática de seus seguidores, a doutrina da predestinação e do particularismo da graça não eram as únicas palavras pregadas pelos reformadores e nem subsumiam o conteúdo religioso de suas sentenças - para eles, o significado de tais práticas era ainda muito mais distinto.

Todavia, por privilegiar sobretudo esses aspectos, a sociologia pôde compreender o que os levou agirem assim e não de outro modo e, ao mesmo tempo, ela se mostra capaz de interpretar inclusive as consequências paradoxais desencadeadas por aquelas condutas. Ao contrastá-las com seus modelos conceituais, as ciências da cultura produzem juízos sobre a realidade empírica. Os tipos ideais somente ordenam em pensamento certos problemas de uma efetividade histórica muito mais intrincada que se desdobra na vida social. Sem expectativa de uma objetividade inconteste e despida de toda volição normativa, a sociologia torna-se finalmente equiparável a qualquer outro saber racional empírico. Segundo Weber:

Obtém-se um tipo ideal mediante a acentuação unilateral de um ou vários pontos de vista, e mediante o encadeamento de grande quantidade de fenômenos isoladamente dados, difusos e discretos, que podem ocorrer em maior ou menor número ou mesmo nunca, e que se ordenam segundo pontos de vista unilateralmente acentuados, formando um quadro homogêneo de pensamento. Torna-se impossível encontrar empiricamente na realidade esse quadro, na sua pureza conceitual, pois trata-se de uma utopia. A atividade historiográfica defronta-se com a tarefa de determinar, em cada caso particular, a proximidade ou o afastamento entre a realidade e o quadro ideal, em que medida portanto o caráter econômico das condições de determinada cidade poderá ser qualificado como "economia urbana" em sentido conceitual. Ora, desde que cuidadosamente aplicado, esse conceito cumpre as funções específicas que dele se esperam, em benefício da investigação e da representação. ${ }^{310}$

Posto isto, faz-se necessário retornar a Adorno. Na introdução de sua DN, o frankfurtiano ressalta a necessidade de um processo de desencantamento do conceito a fim preservar na reflexão

310 Ibidem, idem; p. 73. 
teórica o seu componente crítico. Deixados por sua conta e risco, o pensamento objetivador e a lógica da identidade repisam por suas categorias um esquema antropológico primário. Todo conceito impõe-se a seus objetos como um predador se comporta ao farejar a aproximação de suas presas. Ambos projetam-se sobre outros seres ou sobre a empiria animados por um automatismo sui generis. Devido ao seu caráter puramente instrumental, esta forma peculiar de encarar e de lidar com as coisas replica-se nas mais diversas situações. Em todas elas, a ratio efetiva-se por meio de uma mecânica a um só tempo falsa e violenta.

O salto que precede o ataque de um predador é coberto de incertezas. Para minorar suas dúvidas a respeito de seu lugar de proeminência na cadeia alimentar, ele precisa apavorar as suas vítimas com uma fúria incontrolada. Por vezes, o valente predador afugenta-se de suas próprias sombras. Independentemente de estar diante de uma ameaça concreta ou de um puro devaneio, a sua conduta é sempre a mesma e o seu objetivo é somente perpetuar um ciclo vicioso. Com uma brutalidade aberta e habitual, a violência pela qual ele assedia suas presas cumpre uma função adicional e bastante suspeita. Ao confinar aquilo que seja diferente à reprodução de uma mesma lógica abjeta, essa disposição agressiva ante qualquer alteridade é preservada de todo questionamento. O terror paralisa as suas vítimas e as torna suscetíveis a uma espécie de clamor interno por uma hierarquia estabilizada pelo medo. Se quem mora entre feras sente inevitável necessidade de ser fera também, um baixo patamar de civilidade é o pressuposto desse longevo esquema de dominação.

No âmbito do espírito, a esfera conceitual visa dotar a realidade empírica com a racionalidade do cálculo matemático. Ao se cindir de qualquer conteúdo concreto, a razão acredita poder abandonar as suas próprias origens por subsumir o que seriam as indecisões e o caráter caótico da empiria. Esse princípio se universaliza com as operações mercantis, cuja forma característica de fetiche faz trocar as relações com as coisas por seus nomes reificados ${ }^{311}$. Sob o

311 Acerca dessa questão, cito a bela análise de Gillian Rose das diferenças entre as críticas à reificação em Lukács, Benjamin e Adorno, em The melancholy science. A respeito da especificidade da crítica de Adorno: "O conceito de Adorno de reificação é consistente e original. Muitas de suas aparente confusões surge de sua postura de evitar 
influxo de tal ofuscamento, dilui-se a historicidade dos fenômenos sociais e das formas da vida coletiva em um emaranhado de abstrações. A infinitude daquilo que seja heterogêneo e específico é reduzido a categorias pré-formadas por um espírito que se imagina puramente sublime. Os restos e as sobras inerentes a esses seus procedimentos são extirpados como algo contagioso. No lugar de uma demorada reflexão que reconheça as particularidades dos objetos, afirma-se acriticamente uma forma de atividade intelectual concebida como um sofisticado e regressivo instrumento de dominação. Em DN:

A pretensão imanente ao conceito é sua invariância criadora de ordem ante a mudança daquilo que é compreendido por ele. É essa mudança que é negada pela forma do conceito, "falsa" em si mesmo aí. Na dialética, o pensamento levanta uma objeção aos arcaísmos de sua conceptualidade. O conceito em si hipostasia, antes de todo conteúdo, a sua própria forma em face dos conteúdos. Com isso, porém, se hipostasia mesmo algo fixo, constante, que é simplesmente postulado por uma certa prática de pensamento. O pensamento identificador objetiva por meio da identidade lógica do conceito. A dialética visa, segundo seu lado subjetivo, a pensar de tal modo que a forma do pensamento não mais torne seus objetivos coisas inalteráveis que permanecem iguais a si mesmas; a experiência desmente que eles o sejam. ${ }^{312}$

Pensadas como um contraponto crítico, as constelações correlacionariam sujeito e objeto de

uma forma distinta e superior ${ }^{313}$. Ainda que não abandone o uso dos conceitos e da própria abstração, uma segunda reflexão deve contrabalancear os seus vieses. O momento unificador do espírito e a sua correlata preferência por aquilo que seja abstrato já não mais controlam irrefletidamente as regras do jogo. Tal como a linguagem, as constelações emprestam a objetividade de seus termos do seu contexto de sua anunciação. Ao circundar os objetos em meio a uma densa

fundamentar o pensamento em termos tradicionais, e de seus procedimentos estilísticos usados para fundamentá-los. A teoria de Adorno da reificação era baseada no fetichismo da mercadoria de uma forma que não dependia apenas da teoria do trabalho ou do processo de trabalho (alienação) mas também da teoria de Marx do valor, especialmente da distinção entre valor de uso e valor de troca. Ele era particularmente convicto que a reificação não deveria ser tratada como um 'fato da consciência', uma categoria subjetiva ou sócio-psicológica. Ele acusava muitas versões de críticas à reificação desse equívoco, e tendia a ser sempre ácido tanto com aqueles autores que tentavam definir à reificação nesses termos do que com relação aqueles autores não dialéticos que a endossavam. Ele tentou, também, em sua obra sociológica, fazer da reificação uma categoria empírica." Rose, Gillin. The melancholy science; p. 43.

312 Adorno, Theodor. DN; p. 123

313 A esse respeito, segundo Buck-Morss: "Adorno interpretava cada fenômeno a partir da construção de um processo, isto é, ao 'reagrupar' (umgruppieren) os seus elementos em uma tentativa constantemente renovada de retratar a essência da sociedade. Embora o método de composição de Adorno não era algo formal que pudesse ser divorciado de sua aplicação específica, é no entanto possível discernir certos componentes no processo e os princípios que governam a sua reunião em constelações. (...). Se a super-esquematização, incompatível com o pensamento de Adorno é evitada, é ao menos possível clarificar os princípios de composição de sua teoria ao vê-las em ação." Buck-Morss, Susan. The origins of Negative Dialectics; p. 96. 
teia conceitual, aquilo que a sociedade pretendeu eliminar em seus processos é trazido à tona pela problematização teórica. Desviando-se do olhar recoberto de certeza das ciências modernas, elas subvertem o empedernido pendor por uma classificação hierárquica das coisas em favor de uma nova forma articulação dos saberes. Diante dos escombros de um ideal de sistema que a filosofia chegou a nomear como absoluto, recupera-se o espírito crítico presente em certa arbitrariedade subjetiva dos enciclopedistas franceses ${ }^{314}$.

Talvez de modo surpreendente, o modelo de tais constelações se encontraria nos tipos ideais weberianos. Embora fosse concebida como uma simples construção subjetiva, a noção de composição conceitual cristalizada por esse instrumento analítico ultrapassaria os limites da lógica da identidade - o seu uso rigoroso deixa o objeto constantemente aberto ao pensamento. De acordo com Adorno, Weber se apercebera da dificuldade inerente aos conceitos de um objeto histórico na época de redação de sua Ética protestante. Apenas uma composição gradual e continua de suas tipologias acompanharia pari passu os desdobramentos peculiares de seus objetos. As múltiplas variáveis que concorrem na concreção efetiva das coisas giram ao redor de seu conceito de capitalismo moderno, cuja definição não seria outra senão a dos processos sócio-históricos acumulados. Ao identificá-lo com um espírito que medeia a relação entre os indivíduos e a sociedade, a sociologia weberiana subverteu o princípio da adequação imediata dos termos, e liberou as suas categorias da literalidade e do mecanicismo tão característicos às correntes positivistas. Em DN:

\footnotetext{
Seria necessário recorrer a um estudioso tão disposto para o positivismo quanto Max Weber. Sem dúvida alguma, ele compreendia os “tipos ideias", totalmente no sentido de uma teoria do conhecimento subjetivista, como auxiliares para que nos aproximemos do objeto, auxiliares desprovidos deles mesmos de toda subjetividade e remodeláveis uma vez mais à vontade. Todavia, como em todo nominalismo, ainda que ele também avalie seus
}

314 Segundo Adorno: "Mas a crítica não liquida simplesmente o sistema. No apogeu do iluminismo, D'Alembert distinguiu com razão o esprit de système do esprit systématique e o método da encyclopédie levou em conta essa distinção. O que fala a favor do esprit systématique não é apenas o motivo trivial da vinculação que, certamente, se cristaliza antes na desvinculação; ele não satisfaz apenas a avidez dos burocratas por enfiar tudo em suas categorias. A forma do sistema é adequada ao mundo que, segundo seu conteúdo, se subtrai à hegemonia do pensamento; unidade e concordância, porém, ao mesmo tempo a projeção deformadora de um estado pacificado, que não é mais antagônico, sobre as coordenadas do pensar dominante, repressivo. O duplo sentido da sistemática filosófica não deixa outra escolha senão transpor a força do pensamento, um dia desvinculada dos sistemas, para a determinação aberta dos momentos particulares." Adorno, Theodor. DN; p. 29. 
conceitos como nulos, algo da constituição da coisa transparece e se lança para além da vantagem prática para o pensamento - um motivo nada desprezível para a crítica ao nominalismo irrefletido -, os trabalhos materiais de Weber se deixam guiar muito mais pelo objeto do que seria de se esperar segundo a metodologia da escola alemã do Sudoeste. ${ }^{315}$

Todavia, a cisão intransponível projetada por Weber entre a esfera conceitual e a realidade empírica turvaria a visão sobre as coisas, e um inoportuno ideal por definições jurídicas concorreria com a fertilidade de sua noção de composição conceitual. Por conceber os fundamentos dos seus tipos ideais em nível tão alto de abstração, as clivagens e as contradições sociais deixam de ser pensadas como próprias ao seu objeto. Ademais, quando o autor de ES aspirou por uma tipologia dessa espécie é como se ele apagasse a história de suas categorias e, consequentemente, perdesse a marca mais distintiva e valorosa de suas formulações - reforçando assim a nociva influência do positivismo em sua teoria. Todo material histórico reunido pela desmedida erudição do sociólogo de Heidelberg, o mau uso da abstração impedia que fossem interpretados de forma conveniente.

Como na controvérsia com o positivismo alemão, essa apropriação dos tipos ideais pelo frankfurtiano é indissociável de uma discussão mais ampla. O que fundamenta as divergências metodológicas de Adorno em relação à sociologia de Weber é uma interpretação distinta a respeito da natureza da vida social. A questão decisiva parece se concentrar em torno do significado da própria abstração. Produto da forma de atividade padrão das sociedades modernas, ela forjaria um sentido efetivamente objetivo tanto para as ações individuais como para os fenômenos coletivos, e sedimentaria um grau incomparavelmente maior de substancialidade histórica nos tipos ideais weberianos. Testemunhando os modos peculiares de atuação da totalidade social, os momentos objetivos inscritos nessas composições conceituais transformam o significado do caráter assumidamente particular da sociologia weberiana. O seu ideal de ciência enrijece o pensamento diante do caráter sui generis da dinâmica social moderna, e arrefece a agudeza de sua crítica de maneira imanente. Em Introdução à sociologia:

\footnotetext{
Em outras palavras: ao olhar com mais atenção seus próprios tipos ideais, ele é levado para além de sua definição ou de seu postulado do tipo ideal enquanto um tal instrumento conceitual estritamente abstrato, arbitrário e efêmero, e em direção ao que na
}

315 Ibidem, idem ; p. 142. 
Teoria Crítica se designa como leis objetivas do movimento. Pois se realmente existe algo como uma tendência imanente necessária de que tal tipo ideal transite para além de si mesmo e mude em outro tipo ideal, então isso não abala somente a estrutura monadológica e absolutamente singularizada desses tipos ideais, mas ao mesmo tempo propriamente introduz algo como o conceito de lei social do movimento e nessa medida inclusive uma espécie de estrutura objetiva da própria sociedade, que a rigor é negada por princípio pelo tipo de teoria do conhecimento correspondente a Weber. ${ }^{316}$

No encontro realizado em 2 de julho de seu curso de introdução à sociologia, o frankfurtiano chama atenção para uma contradição fundamental entre os princípios metodológicos weberianos e a sua tipologia das formas legítimas de dominação social. Embora fosse algo que devesse ser proscrito pelos critérios de seu método científico, haveria um movimento inerente entre os seus conceitos de liderança carismática e de dominação legal ou burocrática. Marcuse também apontara para essa questão em seu ensaio sobre o pensamento de Weber, porém é mais interessante ressaltar o tratamento específico conferido por cada um dos autores. Enquanto o primeiro centrará em um debate sobre o conteúdo político pressuposto nos elementos aparentemente mais neutros e abstratos daquela teoria social, o segundo buscava interpretar o significado de uma tal dinâmica entre os tipos ideias weberianos.

Nessa mesma ocasião, Adorno afirmara que o valor maior dessa sociologia se daria justamente naquilo que Weber pretendia eliminar de sua reflexão sociológica, mas que retornava à contragosto de sua vontade e deslocava os seus conceitos ${ }^{317}$. O seu interesse em conceitualizar acerca da atuação de certos elementos irracionais em formas de dominação social diria mais a respeito das sociedades modernas do que se supõe inicialmente. De acordo com Adorno, a perene fluidez de seus tipos sociais documenta a imbricação da razão instrumental com uma irracionalidade da qual ela nunca pôde se desgarrar. Antecipando de modo extraordinário algo característico da modernidade tardia, Weber condensou por seus conceitos uma tendência levada a cabo por desdobramentos imanentes ao capitalismo moderno e de sua respectiva forma de racionalização social. As práticas racionais de dominação não dão conta integralmente de suas funções, e a manutenção da ordem social recorre por motivos intrínsecos à sedução de lideranças 
carismáticas e às regressões próprias da cultura e da política para as massas. Segundo Adorno:

Aqui se impõe deixar de lado o por que ele introduziu esse conceito e qual é para ele a função deste mesmo conceito. O verdadeiro motivo é que ele claramente opinava que nessa forma carismática de dominação se alcançava uma espécie de corretivo para o enrijecimento crescente do burocratismo do mundo burguês. Nessa medida há quase cinqüenta anos ele já se percebia essa tendência ao "mundo administrado", mas não se deu conta, ou talvez na época não poderia ter-se dado conta de que o conceito de "líder carismático"// (charismatischer Führer), no sentido da expectativa média de que ordens proferidas em nome do carisma efetivamente são obedecidas, não funciona como corretivo para a dominação burocrática, mas é especialmente adequado a se fundir com a dominação burocrática. Isso vale tanto para o Estado fascista do Führer quanto para o que ficou conhecido como culto à personalidade nos sistemas stalinistas. ${ }^{318}$

Contudo, na construção do objeto de sua ciência, Weber cinde o seu pensamento de maneira acrítica. De acordo com Adorno, embora as regularidades sociais se distinguam qualitativamente das encontradas pelas ciências da natureza, a própria separação entre conhecimento idiográfico e nomológico em sociologia é insustentável em virtude da forma de organização da vida coletiva aquilo que é factual é resultado de sua própria historicidade. Ao restringir a sua interpretação apenas ao que fosse compreensivo nos fenômenos sociais, a sociologia weberiana menosprezaria a atuação de aspectos decisivos das sociedades modernas. Os desdobramento irracionais imanentes à reiteração da equação entre meios e fins ficam de fora do escopo de suas preocupações, e o juízo axiologicamente neutro acerca do carisma o faz abdicar da pergunta sobre as causas e os motivos de seu encantamento ${ }^{319}$.

Independente da vontade manifestada pelo sociólogo, uma estrutura social objetiva emerge em meio da reflexão demorada e em constante contato com a empiria. Ela possui as suas particularidades, e isso lhe dota de um caráter específico. Porém, o seu aspecto etéreo não alivia a sua espessura turva e nem a sua consistência de chumbo. A persistência de tal experiência é incontornável na modernidade capitalista, e a faz relembrar sociedades pré-históricas. Ainda que mais pareçam resquícios de processos sociais do passado, elas subsistem em virtude e em função do presente. O que é racional impõe-se como totalidade e, por isso, torna-se progressivamente incompreensível $^{320}$.

318 Ibidem, idem; p. 285-286.

319 Ibidem, idem; p. 286.

320 A esse respeito, segundo Müller-Doohm: "Porque a sociedade é tanto racional em seus meios e irracionais em seus 
Nesse sentido, o critério que Émile Durkheim elegeu para dar cientificidade à sua sociologia - isto é, tratar os fatos sociais como coisas - não é apenas coetâneo, mas nasce imbricado ao próprio processo de racionalização social ${ }^{321}$. O seu fundamento advém do funcionamento da própria sociedade, cuja forma de objetividade se sobrepõe sobre a vida dos indivíduos. Da mesma maneira, a psicanálise freudiana encontra-se com a sociedade sobretudo quanto ela mergulha com profundida na dinâmica pulsional individual. As reações subjetivas mais ordinárias, aquelas nas quais as condutas humanas aparentam recobrar uma certa herança biológica, são também socialmente mediadas $^{322}$. Tais momentos testemunham a atuação da sociedade como um objeto, cuja pedra de toque não indica a pureza de seus procedimentos, mas revela a própria coisificação de seus processos. Segundo Adorno:

\begin{abstract}
Apesar de a própria sociedade ser racional em seus meios, essa racionalidade dos meios constitui efetivamente, conforme Weber, apenas uma racionalidade de meios e fins, ou seja, sua validade existe no intervalo entre os fins postos em cada caso e os meios utilizados para tanto, sem se referir aos próprios fins, isto é, justamente àquele fim de uma preservação satisfatória e recompensadora da espécie como um todo. É por esse motivo // que as irracionalidades não apenas se conservam, mas de certo modo se reproduzem de maneira ampliada; diga-se de passagem que essa é a explicação mais apropriada da importância que os chamados momentos psicológicos e psicossociais têm nessa sociedade. Penso que a derivação objetiva da irracionalidade, ou se quiserem, a derivação racional dessa irracionalidade, constituiria peça essencial da Sociologia que se apresenta hoje em dia. $^{323}$
\end{abstract}

\title{
Críticas ao valor.
}

“O ponto de fuga do materialismo histórico seria

fins, o critério de não-contradição não pode ser mantido para os objetos da sociologia. A ciência da sociedade deve conviver com o paradoxo que o objeto em sua totalidade é tanto compreensivo quanto incompreensivo ao mesmo tempo. Ele é compreensivo porque ele lida com seres humanos que se relacionam uns com os outros; incompreensivo porque esses seres humanos são submetidos a regras abstratas das leis universalizantes da troca. Isso, acredita Adorno, é o que fornece o duplo caráter da sociologia. Seu campo de investigação é tanto objetivo quanto subjetivo. É subjetivo na medida em que as relações sociais são redutíveis a relações entre seres humanos. A sociedade é objetiva, entretanto, como uma entidade estruturada, uma totalidade sistemática na qual os seres humanos são coercitivamente integrados." Müller-Doohm, Stefan. Adorno; p. 428.

321 Tratei com mais vagar das criticas de Adorno à sociologia de Durkheim no capítulo "Émile Durkheim e a dominação da natureza", em O Moloch do presente.

322 A esse respeito, segundo Adorno: “Assim a focalização freudiana do indivíduo oferece um exemplo esplêndido para a minha exigência de descobrir o conteúdo social das categorias peculiares das ciências específicas aprofundando-se nestas e não a partir do que se encontra fora delas. Na teoria freudiana predominam, em primeiro lugar, próximo à superfície e niveladas conforme o princípio de realidade a que todos os homens precisam se adequar, determinadas situações relativamente abstratas e semelhantes. A seguir, quando mergulhamos na chamada dinâmica psíquica, ou seja, quando se gera a diferenciação nos mecanismos inconscientes e sobretudo no movimento interativo entre o inconsciente e o eu individual, apercebe-se o coletivo - e novamente da mesma forma como no cerne da individuação.” Adorno, Theodor. Introdução à sociologia; p. 269-270.

323 Ibidem, idem; p. 307. 
a sua própria suspensão, a liberação do espírito do primado das necessidades materiais no estado de sua realização. É somente com o ímpeto corporal apaziguado que o espírito se reconciliaria e se tornaria aquilo que há muito ele não faz senão prometer, uma vez que sob o encanto das condições materiais ele recusa a satisfação das necessidades materiais." 324

Será necessário abordar ainda um outro tema fundamental para a análise das relações de Adorno com o pensamento de Weber - o seu contraponto ao velho postulado sobre a neutralidade axiológica das ciências sociais. Novamente, a discussão com a sociologia weberiana expõe aspectos importantes do pensamento tardio do frankfurtiano. Trata-se de um debate maior a respeito do papel da teoria e de sua interação com a prática social. Na verdade, o ponto mais interessante para esta pesquisa seria um segundo desdobramento de sua apropriação dos tipos ideais weberianos. Enquanto o autor de A ética protestante retirava qualquer possibilidade das ciências sociais em formular juízos de valor objetivos, para Adorno a crítica sociológica prescinde da simples assunção de um ponto de vista.

A esse respeito, é oportuno recobrar certa implicação do pensamento weberiano. A fim de explicitar o contraste explícito das considerações de Adorno, é oportuno apresentar os termos da equiparação das leis e das categorias do materialismo histórico ao seu conceito de tipo ideal. Naturalmente, essa referência não pretendia oferecer - ou requisitar - guarida acadêmica aos socialistas de sua época. Pelo contrário, a sua intenção era afastar as ciências sociais da influência mesquinha de qualquer visão ou concepção de mundo. Em A "objetividade":

Da escolástica à teoria marxista, aqui se entrecruzam duas noções, a do "objetivamente" válido, isto é, de um dever ser, e de uma abstração a partir do processo empírico de formação de preços. A idéia de que o "valor" dos bens deveria ser regulado segundo determinados princípios do "direito natural" teve um incomensurável significado para o desenvolvimento da nossa civilização - e não apenas na Idade Média - e ainda hoje o tem. Em especial, influi intensamente no processo empírico da formação dos preços. Ora, se é apenas mediante uma construção rigorosa dos conceitos, ou seja, graças ao tipo ideal, que se torna possível expor de forma unívoca o que se entende e se pode entender pelo conceito teórico do valor. ${ }^{325}$

Posto isto, convém voltar a Adorno. De acordo com o frankfurtiano, uma sociedade que se

324 Ibidem. DN; p. 176.

325 Weber, Max. A "objetividade"; p. 86. 
reproduz visando unicamente garantir a racionalidade dos meios desdenha que seu desenvolvimento se dê independentemente e, por vezes, reforçando a irracionalidade dos fins. Somente uma teoria social é capaz de revelar que essa separação é fruto da intimação da prática social apreensível apenas com a confrontação entre aquilo que uma sociedade se apresenta e aquilo que ela é. O embaraçoso vazio que se estabelece entre o que as coisas são nelas mesmas e suas potencialidades é preenchido atualmente segundo o gosto dos dominantes - a autonomia do conceito de valor de seu substrato material é acentuado para retirar do horizonte teórico e político a concepção de uma vida correta e não mais danificada. Em "Introdução à controvérsia":

A falsa cisão entre neutralidade de valores e valor revela-se igual à cisão entre teoria e práxis. A sociedade, enquanto entendida como conexão funcional de autocompreensão humana, "quer dizer": tem por fim objetivamente a reprodução de sua vida adequada ao estado de suas forças; fora isto qualquer realização social, e mesma a socialização, constitui um contra-senso no mais simples entendimento cognitivo. A razão subjetiva da relação fins-meios se transformaria, tão logo não fosse detida efetivamente por imperativos sociais ou cientificistas, naquela razão objetiva, que contém o momento axiológico como o próprio momento do conhecimento. O valor e a ausência de valores são mediatizados entre si dialeticamente. Conhecimento algum dirigido à essência imediata da sociedade seria verdadeiro, se não o quisesse assim, medida em que seria portanto "valorativo"; nada há que exigir da sociedade, que não proviesse da relação de conceito e empiria, que não seja portanto essencialmente conhecimento. ${ }^{326}$

Nesses termos, um dos debates centrais da tradição sociológica revira-se ao avesso. A antinomia inevitável do problema dos valores mostra-se como uma formulação indevida ${ }^{327}$. Essa distinção entre a capacidade de formular ou não juízos de valor objetivos seria fruto de uma sociedade na qual uma racionalidade que visa simplesmente a dominação da natureza se hipostasiou. E isso se daria por conta do fato de que o conceito de valor que orienta essa sociedade se formou na relação de troca. A externalidade possível entre uma esfera de valores e seu substrato material é resultado de uma sociedade que pretende cristalizar em duas esferas distintas aspectos

326 Adorno, Theodor. "Introdução à controvérsia"; p. 254.

327 A esse respeito, em Introdução à sociologia: "Tão impossível quanto a idéia weberiana da neutralidade axiológica absoluta é também a vinculação de conhecimentos sociológicos a valores trazidos de fora e por isso reificados e fixos (...). Creio antes que, em uma variante de uma expressão de Feuerbach, não se deve ser, nem contra a neutralidade axiológica, nem contra valores, mas acima de ambos, ou seja, encarar essa alternativa como um todo enquanto expressão de uma reificação, tal como esta ainda não podia ser pensada por Kant, por exemplo, que distinguiu entre preço e dignidade de um objeto ou de um comportamento. Não é por acaso que o termo "valor" lembra a economia e o mercado, a partir de onde, mediante um desvio passando por Münsterberg, Windelband, Rickert, penetrou nas ciências sociais. O próprio termo constitui também a expressão de uma reificação, da mesma forma que a neutralidade axiológica, a posição que lhe é contraposta, também expressa uma consciência reificada." Ibidem, idem; p. 199-200. 
inseparáveis da totalidade da vida social. Em uma sociedade produtora de mercadorias, onde o processo de valorização subjuga o processo de trabalho, onde o valor de uso aparece apenas como simples substrato material do valor de troca, coagulou-se em duas esferas que ora se mantém separadas, ora aparecem indissociáveis, da vida social: os fins e objetivos da sociedade e os meios e os instrumentos para efetivá-los.

Todavia, a sociedade se compõe de sujeitos e se constitui em virtude da conexão funcional entre eles. A involução permanente que eles experimentam - isto é, de pelo seu próprio movimento, a sociedade ter efetivado seu conceito como algo primitivo e impenetrável - não extirpa das determinações da realidade social a representação de uma associação de indivíduos livres e racionais, e nem a potencialidade dela se configurar conforme os princípios de uma vida melhor. Por mais que suas promessas sejam negadas historicamente, o fato de que não só a sociedade seja mediada pelo sujeito, mas que o próprio sujeito incida ativamente sobre a objetividade social exige da sociologia que reflita sobre a relação entre a teoria e a práxis social. Isto porque, os problemas normativos que cada sociedade determinada enfrenta erigem-se a partir de suas constelações históricas particulares. Em "Notas marginais":

A Wertfreiheit weberiana estava amarrada ao seu conceito de racionalidade. Falta saber qual das duas categorias sustenta a outra, na versão weberiana. Como se sabe, racionalidade, centro de toda obra de Weber, significa, para ele, preponderantemente racionalidade com vistas aos fins [Zweckrationalität]. Ela é definida como a relação entre os meios adequados e os fins. Estes estão fora da racionalidade por princípio; ficam entregues a uma espécie de decisão, cujas lúgubres implicações, que Weber não quis, não tardaram a manifestar-se após a sua morte. Mas tal isenção dos fins do campo da "ratio", a qual Weber cercou de restrições, mas que, mesmo assim, inegavelmente configurou o teor de sua doutrina e até de sua estratégica científica, não é menos arbitrária do que a decretação dos valores. ${ }^{328}$

Esse arranjo social porta consigo a sua figura específica da razão e produz os seus próprios entraves. O sinal de alarme de seu progresso irrefreado foi desencadeado pelos processos regressivos tão peculiares ao ordenamento social da modernidade tardia. A sua dinâmica histórica é dialeticamente associada a uma estática igualmente histórica, cuja disposição imediata reproduz os baixos padrões de sociabilidade vigentes. Na aurora do capitalismo liberal, essa estática assumiu as

328 Ibidem. "Notas marginais sobre teoria e práxis"; p. 221. 
formas clássicas das modernas relações de produção. Embora elas não permaneçam inalteradas, as suas transformações não suprimiram o velho princípio de sua dinâmica ${ }^{329}$.

A penúria material que por séculos parecia zombar de qualquer conceito de progresso foi definitivamente afastada, e há tempos ninguém mais deveria padecer de fome em vistas do nível de desenvolvimento atingido pelas chamadas forças produtivas. Todavia, o princípio da troca de equivalentes mantém os seus antigos privilégios. O tipo característico de sua desigualdade que ele não apenas esconde, mas reforça e reproduz de maneira ampliada continua a comandar as regras do jogo. A sua perpetuação não destrói o sistema econômico, porém esgarça as formas de sociabilidade e as tornam dignas de rememorar processos bárbaros tanto por suas práticas quanto por seu ofuscamento. A persistência da carência e da opressão é fruto da ausência de um sujeito global consciente de si, cujo lugar permanece sendo ocupado por sua versão reificada. Organizado como uma totalidade, o empedernido controle sobre a natureza externa e interna do homem não evita que as coisas piorem, posto que ao se enfurnar em uma busca sempre infinita por identidades ele comete injustiças crescentes contra o não-idêntico. Em "Progresso":

A convergência de um progresso total com a negação do progresso, na sociedade burguesa que criou este conceito, origina-se do princípio dessa sociedade: a troca. Ela é a configuração racional da invariabilidade mítica. Na equivalência - igual por igual - de toda operação de troca, um ato compensa o outro, e vice-versa; o saldo se reduz a zero. Se a troca foi justa, nada terá ocorrido, tudo permanece como antes. Mas, ao mesmo tempo, a afirmação do progresso - antagônica em relação àquele princípio - é tão verdadeira quanto é mentira a doutrina da troca de equivalentes. Desde sempre, e não só depois que começou a apropriação capitalista da mais-valia na troca de mercadoria força de trabalho por seu custo de reprodução, o contratante socialmente mais poderoso recebe mais do que o outro. Por meio desta injustiça, acontece algo de novo na troca: o processo que proclama sua própria estática torna-se dinâmico. A verdade do acréscimo nutre-se da mentira da igualdade. ${ }^{330}$

O éter social que perpassa qualquer de seus momentos confere um conceito objetivo a toda singularidade particular. Um saber eminentemente crítico procede de um modo distinto e radical. Qualquer singularidade particular é mediada pela totalidade social, o que lhe confere objetivamente um conceito, uma intenção à universalidade. É certo que até hoje, todo o discurso universal foi

\footnotetext{
329 A esse respeito, seria interessante lembrar um ensaio de Adorno sobre a sociologia de Auguste Comte, o "Sobre estática e dinâmica como categorias sociológicas". Tal ensaio do frankfurtiano foi objeto de análise do capítulo "Estática e dinâmica como história sedimentada", em O Moloch do presente.

330 Adorno, Theodor. "Progresso"; p. 59-60.
} 
forjado para esconder os seus propósitos particulares e, não raro, comezinhos. Um criado de quarto sempre sabe das covardias e das vontades apequenadas daqueles que se dizem heróis. O desafio da crítica é transformar o engodo não em motivo de lamentação ou de chacota, mas em critério de justiça e de verdade.

Conquanto o princípio de equivalência seja desrespeitado nas trocas cotidianas - e, fundamentalmente, com relação à mercadoria força de trabalho -, ele forja o padrão de medida das coisas. Caso se pretenda suprimir abstratamente essa medida de comparatibilidade, a humanidade voltaria à apropriação direta, à pura violência e, atualmente, ao privilégio nu e cru dos monopólios e dos cliques $^{331}$. O verdadeiro progresso em relação à troca se daria pela superação dela mesma, isto é, pelo cumprimento exato dos seus termos, e suprimir tanto a forma da prática social que universaliza abstração irrefreada quanto as suas regressivas repercussões na vida individual e, ainda, o enviesamento positivista na atividade intelectual. Do contrário, a vida social persiste em sua ofuscação, e a reflexão teórica depara-se com os seus limites que não são outros do que os que fundamentam as sociedades capitalistas. Em DN:

A crítica ao princípio da troca enquanto princípio identificador do pensamento quer a realização do ideal de uma troca livre e justa que até os nossos dias não foi senão mero pretexto. Somente isso seria capaz de transcender a troca. Se a teoria crítica desvelou a troca enquanto troca do igual e, contudo, desigual, então a crítica da desigualdade na igualdade também tem por meta a igualdade, apesar de todo ceticismo em relação ao rancor próprio ao ideal de igualdade burguês que não tolera nada de qualitativamente diverso. Se não mais se retivesse, de nenhum homem, uma parte de seu trabalho vital, então a identidade racional seria alcançada e a sociedade estaria para além do pensamento identificador. $^{332}$

331 Ibidem. DN; p. 128.

332 Ibidem, idem. DN; p. 128. 


\section{Cap. 4 - Max Weber e ratio em sua irracionalidade. Uma interpretação de Marcuse.}

"Sou membro da classe burguesa, sinto-me como tal e fui educado nas suas concepções e nos seus ideais. Cumpre, contudo, justamente à nossa ciência dizer o que não se aprecia ouvir - para cima, para baixo e também para a própria classe.”333

"Enquanto na vida comum qualquer shopkeeper sabe muito bem a diferença entre o que alguém faz de conta que é e aquilo que ele realmente é, nossa historiografia ainda não atingiu esse conhecimento trivial. Toma cada época por sua palavra, acreditando naquilo que ela diz e imagina sobre si mesma." 334

De acordo com Marcuse, a visceral repulsa manifestada por Weber contra os movimentos socialistas e contra os intelectuais revolucionários de seu tempo - recomendando a eles, o manicômio, o jardim zoológico ou o tiro de revólver ${ }^{335}$ - ultrapassa os humores de uma simples paixão e refugia-se sobriamente na tessitura de seus conceitos. Contudo, muito embora a adesão explícita ao que seria a missão histórica de sua classe detenha a sociologia weberiana em momentos decisivos, a aguda concretude de seu pensamento aliada às fissuras inerentes à engrenagem que dita as normas nas sociedades industriais avançadas ${ }^{336}$ fazem de sua teoria sociológica algo mais espinhoso do que um simples objeto de refutação ideológica tradicional ${ }^{337}$.

Em certo sentido, se a recomendação de não levar a sério aquilo que uma época ou um

333 Weber, Max. “O Estado nacional e a política econômica”; p. 74.

334 Marx, K e Engels, F. A ideologia alemã; p. 50.

335 Marcuse, Herbert. “Industrialização e capitalismo na obra de Max Weber”; p. 119.

336 De acordo com Silvio Carneiro, com esse conceito de sociedades industriais avançadas, Marcuse caracteriza tanto a estrutura social do capitalismo tardio quanto a soviética, durante o pós-guerra. Por meio dessa ampliação de escopo, Marcuse visava construir uma crítica capaz de superar também os limites de algumas correntes do marxismo de seu tempo. Carneiro, Silvio. O discurso ontológico e a teoria crítica de Herbert Marcuse; p. 3. A esse respeito, em A ideologia da sociedade unidimensional, Marcuse afirma: "Nessa sociedade, o aparato produtivo tende a tornar-se totalitário no quanto determina não apenas as oscilações, habilidades e atitudes socialmente necessárias, mas também as necessidades e aspirações individuais. Oblitera, assim, a oposição entre existência privada e pública, entre necessidades individuais e sociais. A tecnologia serve para instituir formas novas, mais eficazes e mais agradáveis de controle social e coesão social. A tendência totalitária dessas controles parece afirmar-se ainda em outro sentido - disseminando-se pelas áreas menos desenvolvidas e até mesmo pré-industriais e criando similaridades no desenvolvimento do capitalismo e do comunismo.” Marcuse, Herbert. A ideologia da sociedade industrial; p. 18.

337 Em sua nota de tradutor presente na edição brasileira do segundo volume de Cultura e Sociedade, Wolfgang Leo Maar afirma que em nesse artigo Marcuse elabora sua crítica à sociologia weberiana sem perder de vista as vicissitudes e peculiaridades inerentes às sociedades modernas tardias. Segundo Leo Maar: “A contribuição de Marcuse procura levar avante a crítica da economia política sem deixar de considerar, porém, as dificuldades provenientes da própria racionalidade consolidada pelo sistema, que obstruem qualquer esquema do tipo 'contradição entre forças produtivas e relações de produção'.” Marcuse, Herbert. “Industrialização e capitalismo na obra de Max Weber”; p. 135. 
indivíduo imagine sobre si mesmo continua válida para Weber, também é verdade que sua sociologia descola-se radicalmente de qualquer defesa ingênua das relações sociais capitalistas. Em sua refinada consciência das contradições e dos antagonismos sociais modernos, a elaboração conceitual weberiana conseguiu captar inclusive algumas tendências e fenômenos fundamentais das sociedades no capitalismo avançado.

É certo que o antigo elo diagnosticado entre a condução da economia deixada a cargo do empresário capitalista individual e o ascetismo intramundano como código de conduta ética perdeu suas justificativas econômicas. Porém, a produção e da distribuição da riqueza social, as formas culturais de uma sociedade de massas e a correspondente formação subjetiva dos indivíduos persistem como funções da reprodução econômica do capitalismo avançado. Ainda que a vida social moderna tenha se alterado desde os tempos de Weber, a crítica ao seu pensamento pode fomentar uma denúncia rigorosa daquilo que foi feito com os homens e com as coisas. Tornado patente pela irracionalidade do arranjo social tardio, o conteúdo e a orientação política que sempre sustentou as sociedades modernas revelam as suas feições pelo exame crítico da sociologia weberiana. Em “Industrialização e capitalismo na obra de Max Weber”:

Segundo Max Weber, a racionalidade capitalista encontra o nexo central de sua realidade efetiva na iniciativa (Unternehmung) privada; o empresário é uma pessoa livre, responsável ele mesmo por seus cálculos e pelos seus riscos. Enquanto tal o empresário é cidadão (Bürger), e o modo de vida da burguesia (Bürgertum) encontra na "ascese intramundana” sua expressão representativa. Tal concepção ainda se manteria válida hoje? A burguesia em que Max Weber enxergou o portador (Träger) do desenvolvimento industrial ainda é o portador do desenvolvimento industrial do capitalismo desenvolvido? A racionalidade capitalista desenvolvida ainda é a razão gerada na "ascese intramundana"? Penso que a resposta a essa questão deve ser negativa. Na consumação da própria racionalidade capitalista as formas que lhe foram atribuídas por Max Weber foram demolidas, superadas, e sua demolição faz com que a ratio da industrialização capitalista apareça sob uma luz bem diferente - à luz de sua irracionalidade. ${ }^{338}$

Os nexos entre os conceitos de capitalismo moderno, de racionalidade e de dominação constituiriam o cerne do pensamento weberiano. No entanto, a questão que mais interessa ao frankfurtiano é o caráter inerentemente problemático de tais categorias. A desmedida erudição do sociólogo de Heidelberg, que lhe permitiu distinguir o acessório do essencial, a manifestação da

338 Ibidem; p. 118. 
realidade e abarcar com suas definições a verdadeira efetividade das coisas, não o tornou capaz de ir além da conceitualização acerca de uma razão formal, apresentada como algo insuperável e que ameaça se eternizar. Para Marcuse, a agudeza crítica de seu pensamento se retrairia em pontos essenciais. O radical processo de abstração da ratio por meio do qual Weber procurou acertadamente interpretar as sociedades modernas parece querer se dissociar de sua matéria social e, inopinadamente, acredita ter se tornado um círculo girando no vazio ${ }^{339}$.

O método weberiano de definições formais, a construção de um saber pretensamente desprovido de valores, as suas classificações e as suas tipologias abstratas cristalizariam não apenas a época na qual a qualidade se reduz à quantidade. Na verdade, tal postura intelectual caracteriza ainda os limites internos dessa forma específica de racionalidade. Ao acompanhar de maneira imanente o movimento dos conceitos da sociologia weberiana, Marcuse afirma ser possível compreender a irracionalidade subjacente às sociedades modernas. Seja na legitimação da manipulação de carências materiais seja cobrindo de culpas e de tabus o desfrute de objetos de desejo, o resultado da atuação desta forma específica 'de razão mostra-se eivada por propósitos particulares. Segundo Marcuse:

Assim, no desenvolvimento da racionalidade capitalista a irracionalidade se torna razão: razão enquanto desenvolvimento frenético das forças produtivas, conquista da natureza, ampliação da riqueza de mercadorias (e do acesso a elas mesmas para camadas mais amplas da população); mas irracional porque a produtividade superior, a dominação da natureza e a riqueza social se tornam forças destrutivas, destrutivas não só no sentido figurado, na liquidação dos chamados valores superiores, mas em sentido literal: a luta pela existência se aguça tanto no plano interno dos Estados nacionais como no plano internacional, e a agressão represada se descarrega na legitimação de crueldades medievais (a tortura) e no genocídio promovido cientificamente. - Houve uma previsão desse desenvolvimento por parte de Max Weber? A resposta é: não, na medida em que se acentua a "visão". Contudo ela se encontra implícita em sua formação conceitual, e de modo tão profundo que aparece como inevitável, como definitivo e por isso aparece novamente como racional (no mau sentido). ${ }^{340}$

Por conta de tal enviesamento, Weber conceberia o socialismo a partir da regressiva e

339 A esse respeito, segundo Gandesha: “O ponto de partida da crítica de Marcuse a Weber é a alegada 'neutralidade axiológica' da ciência social, da qual o conceito de racionalidade formal é um exemplo. Marcuse realiza a crítica de tal noção situando solidamente Weber no contexto político da Alemanha guilhermina. Toda a força da crítica de Marcuse reside em mostrar como, em sua insistência sobre a neutralidade axiológica, o conceito de racionalidade de Weber revela sua inegável determinação política." Gandesha, Samir. "Marcuse, Habermas and the critique of technology.” p. 191.

340 Marcuse, Herbert. “Industrialização e capitalismo na obra de Max Weber”; p. 119. 
questionável ideia de que as conquistas do progresso tecnológico e da industrialização fossem as únicas imagens plausíveis do futuro. Tampouco a transformação radical das relações de propriedade modernas seria suficiente para subtrair do aparelho burocrático a sua autoridade sobre o curso do mundo. Toda alternativa utópica permanece circunscrita ao enfadonho espectro do passado. Estariam resguardadas as vitórias da disciplina sobre a real satisfação das necessidades, a da dominação racional das coisas sobre a vida individual e coletiva e a eternização da luta dos homens pela sobrevivência.

O socialismo - o grande equívoco da história mundial ${ }^{341}$ - só poderia ser pensando a partir dos mesmos paradigmas de racionalidade, de dominação e de organização da produção material de mercadorias vigentes nas sociedades capitalistas liberais. A questão se afastaria de toda intelecção acerca das possibilidades de outra forma de relacionamento entre os homens e deles com a natureza, de uma nova e progressista configuração da vida social e, por fim, de uma concepção verdadeiramente harmônica e emancipada da própria humanidade. Segundo Marcuse:

Com estas palavras Max Weber cita uma tese do socialismo; ele não a contesta, mas acredita que também a sociedade socialista não mudará nada no fato básico da separação dos trabalhadores dos meios de produção, simplesmente porque ela é a forma do progresso técnico, da industrialização. Também o socialismo permanece subordinado à sua racionalidade se pretende por sua vez permanecer fiel a sua própria promessa da satisfação universal das necessidades e da pacificação da luta pela existência. O domínio das coisas sobre os homens pode ser despojado de sua irracionalidade, segundo Max Weber, unicamente no domínio racional dos homens sobre os homens. Portanto, inclusive para o socialismo a questão que se coloca é: “Quem deverá assumir e comandar essa nova economia?" 342

Dessa maneira, um conjunto similar de temas e de conceitos com os quais Horkheimer e Adorno também dialogaram em alguns de seus textos surge na discussão de Marcuse com a sociologia weberiana. A crítica à instrumentalização da razão, questões metodológicas e entendimentos distintos sobre a natureza do conhecimento nas ciências sociais, a tentativa de interpretação do papel da ciência e de sua atuação tanto na produção de riqueza material quanto na legitimação ideológica do capitalismo pós-liberal e a esperança em torno de um outro destino para o mundo moderno são os elementos-chave da relação dos frankfurtianos com Weber. 
Porém, tal como nos capítulos anteriores, o objetivo visado por esta pesquisa não se resume em apontar certas proximidades temáticas entre esses autores. A apropriação realizada por Marcuse suscita outras questões, cujas respostas são formuladas de um modo bastante particular. Ao lado de uma interpretação a respeito do novo papel do ascetismo intramundano no capitalismo avançado, é preciso sublinhar desde já a sua inclinação em pensar as contradições peculiares à política moderna em meio a uma discussão com categorias weberianas. O mais interessante, portanto, é tentar revelar os momentos nos quais a crítica de cada um dos frankfurtianos opera de maneira específica e possui o seu sentido próprio ${ }^{343}$.

\section{A sociedade afluente e seus entraves.}

Antes de me ater à interpretação de Marcuse da sociologia weberiana, convém uma breve reconstrução de alguns elementos de sua teoria social ${ }^{344}$. Bem como os outros frankfurtianos, a leitura marcuseana da obra de Weber está calcada em uma refinada compreensão da natureza do capitalismo avançado.

O seu interesse, portanto, não se restringe a um exercício acadêmico de exegese do pensamento de um clássico da sociologia. Para Marcuse, as formulações weberianas a respeito da razão ocidental, das formas contemporâneas de dominação e de controle sociopolítico e da formação subjetiva dos indivíduos modernos se confundiriam com tendências sociais vigentes nas

343. A esse respeito, segundo Kellner: "The specific reality principle that governs behavior and creates suplus repression in contemporary societh is the performance principle: 'under its rule society is stratified according to the competitive economic performances of its members'. The performance principle 'is that of an acquisitive and antagonistic society in which domination is perpetuated by a ruling class. It is related to what Max Weber called the 'spirit of capitalism', or what is today called the 'work ethic'. It also suggests a role-stratified society in which one performs according to pre-established norms and rules, thus conforming to social roles and behavior. In a society of increasing social control, all aspects of life - labour, leisure, even sexuality - are directed by the dictates of the performance principle. Bus the realm in which it inflicts its heaviest damage and makes its severest demands in the realm of labour.” Kellner, Douglas. Herbert Marcuse and the crisis os marxism; p. 169.

344 A esse respeito, segundo Kellner: "O ensaio de Marcuse sobre Max Weber contém uma clarificação importante da relação entre o capitalismo e a tecnologia que supera a análise algo a-histórica de $\mathrm{O}$ homem unidimensional mostrando como a racionalidade tecnológica se desenvolve dentro do sistema capitalista e como o desenvolvimento capitalista da ciência e da tecnologia produz a sociedade unidimensional. Mais do que estarem 'fora de controle' ou serem 'automatizadas', a ciência e a tecnologia são controladas e foram constituídas por forças sociais específicas e possuem funções sociais específicas, que fazem do capitalismo avançado qualitativamente diferente de formações sociais anteriores. Assim, apesar de passagens que sugerem um parentesco com teóricos do 'tecnologia autônoma" como Ellul ou Heidegger, para Marcuse a tecnologia é usada como um instrumento de controle social e de lucratividade.” Kellner, Douglar. Herbert Marcuse anda the crisis of marxism; p. 266. 
sociedades industriais avançadas - a sua crítica, portanto, significa também uma crítica dessa mesma sociedade.

A utilização em larga escala da ciência e da tecnologia na produção e na circulação de mercadorias tornou-se um fenômeno decisivo após o fim do período liberal do capitalismo moderno. As suas repercussões estendem-se para além das questões concernentes à organização do trabalho fabril ou acerca do provimento de produtos industrializados para o conjunto da população. Na verdade, as condições mais elementares da sociabilidade moderna alteraram-se sob esse novo contexto.

Ora, a ratio multiplica por números inimagináveis a produção de bens materiais e de excedentes, apazigua o interior das fábricas ao transformar o trabalho em algo menos estafante fisicamente e ao descolar da figura do capitalista a identidade imediata com a exploração econômica e, à primeira vista, satisfaz desejos e supre carências dos diferentes membros das sociedades modernas. O avaro véu tecnológico, que demonstra toda sua mesquinhez em sua sanha pela extração de mais-valia, é pródigo em subministrar paliativos a fim de garantir a reprodução das desigualdades e conter a revolução das sociedades modernas. O custo de tamanho disparate é ainda mais elevado. Paga-se o dispendioso de transformar os homens em coisas e as coisas em mero objeto de manipulação instrumental. Em O homem unidimensional:

Acabo de sugerir que o conceito de alienação parece tornar-se questionável quando os indivíduos se identificam com a existência que lhes é imposta e têm nela seu próprio desenvolvimento e satisfação. Essa identificação não é uma ilusão, mas uma realidade. Contudo, a realidade constitui uma etapa mais progressiva de alienação. Esta se tornou inteiramente objetiva. O sujeito que é alienado é engolfado por sua existência alienada. Há apenas uma dimensão, que está em toda parte e tem todas as formas. As conquistas do progresso desafiam tanto a condenação como a justificação ideológicas; perante o tribunal dessas conquistas, a "falsa consciência” de sua racionalidade se torna a verdadeira consciência. ${ }^{345}$

Pois o progresso que se impõe sobre os indivíduos orienta-se consoante os limites da apropriação privada de mais-valia e da exploração capitalista do trabalho humano. Ele já não mais se efetiva avançando extensivamente sobre as áreas pré-capitalistas, mas principalmente a partir da

345 Marcuse, Herbert. A ideologia da sociedade industrial; p. 31. 
intensificação das modernas relações econômicas e da malversação dos resultados obtidos pela ciência e pela tecnologia para fins desumanos. Estas, comprometidas desde o seu interior, forjam o momento histórico no qual o mais alto grau de produtividade do trabalho é usado para a perpetuação do mesmo enquanto a mais eficiente industrialização serve para difundir restrições e manipular carências ${ }^{346}$.

Tais sociedades permitem aos seus membros um padrão de vida inimaginável para qualquer formação social do passado. Não obstante, há ainda tantos antagonismos sociais e distinções de classe cuja reprodução oblitera qualquer transformação qualitativa no seio da vida coletiva. Esse novo arranjo mostra-se capaz de impedir a revolução socialista em um futuro próximo. No entanto, ele traz consigo determinadas tendências destrutivas que se tornam cada vez mais vigorosas. A ideia de progresso é corrompida e os objetivos pelos quais ela deveria se pautar - isto é, aqueles definidos pelas possibilidades de real uma melhora da condição humana ${ }^{347}$ - são substituídos pelo enganoso e artificial prolongamento do reino da necessidade. Em "Industrialização e capitalismo na obra de Max Weber”:

Max Weber não mais presenciou como, na própria eficiência de sua razão, o capitalismo desenvolvido torna mesmo a destruição planejada do trabalho desta em fonte de maior e melhor prosperidade, como mesmo a loucura explícita se converte em fundamento não apenas da continuidade mas, inclusive, de uma vida mais prazerosa. Ele já não vivenciou a affluent society que, em face da miséria desumana e da crueldade sistemática fora de suas fronteiras, desperdiça suas incríveis forças técnicas, materiais e intelectuais, malversando-as para a mobilização permanente. ${ }^{348}$

A aplicação da ciência moderna e da tecnologia na produção material e na circulação de mercadorias abriria espaço para um mundo em outro patamar civilizatório ${ }^{349}$. Caso não houvesse exploração privada da força de trabalho humana, a automatização poderia chegar até os limites técnicos de tornar o tempo de trabalho algo meramente residual. Todavia, de acordo com Marcuse, a

\section{Ibidem; p. 37.}

347 Ibidem; p. 35.

348 Idem. “Industrialização e capitalismo na obra de Max Weber”; p. 129.

349 A esse respeito, sobretudo no capítulo "Liberation and Utopia” de Herbert Marcuse and the crisis of marxism, Kellner elabora uma discussão muito bem fundamentada sobre a visão de Marcuse das potencialidade utópicas negadas pela forma capitalista de aplicação da tecnologia e de desenvolvimento científico. Segundo Kelnner: "Since current technology is bound up - in its structure and function - with domination requires a new technology of liberation. Constructing such a new technology would require an alteration of te current direction of technologycal progress, new ends and goals for technology, and new kinds of technology.” Kellner, Douglas. Herbert Marcuse and the crisis of marxism; p. 331. 
apropriação privada da mais-valia não abandona seus privilégios, a espoliação complementa-se com

a dilapidação e a sociedade industrial avançada conforma-se a isso tudo. É importante ressaltar que sua sobrevida não se dá apesar do aperfeiçoamento científico e do desenvolvimento tecnológico, mas sobretudo por meio deles. Tampouco se é permitido conceber que se trate dos infortúnios decorrentes da momentânea tibieza de seus resultados a ser superada pelo aprofundamento da racionalidade ocidental - essa ímpia persistência, na verdade, está sustentada pela exacerbação de de sua própria potência.

Nesse sentido, há uma malfazeja relação entre essas novas forças produtivas e as já conhecidas relações sociais de produção. A sociedade que poderia ser libertada do trabalho aprisiona-se a ele e paralisa a vida social. No entanto, esse claustro não impele a um movimento ascendente de contestação e de rebeldia contra as normas sociais e contra as relações de propriedade vigentes. Antes o contrário, ele contribui vivamente para a consolidação da tendência de estabilização do capitalismo. A racionalidade tecnológica que se conhece não é outra que a própria razão da dominação. Defronte a entraves de tal magnitude, a antiga ilusão acerca da neutralidade da tecnologia moderna não pode mais ser sustentada ${ }^{350}$. Segundo Marcuse:

350 De acordo com Habermas, Marcuse hesitaria entre duas posturas contraditórias em relação à sua avaliação da ciência e da tecnologia moderna. Diretamente, Marcuse oscilaria entre uma compreensão tradicional de certa inocência e neutralidade política do desenvolvimento das forças produtivas e uma interpretação que o considerava imediatamente como o elemento essencial da dominação no capitalismo avançado. Segundo Habermas: “O próprio Marcuse parece ter dúvidas sobre se tem sentido relativizar a racionalidade da ciência e da técnica a um 'projeto’. Em muitos lugares do One-Dimensional Man, revolução significa de fato apenas uma modificação do quadro institucional que não afeta as forças produtivas como tais. A estrutura do progresso técnico-científico seria então mantida, sendo alterados apenas os valores que o dirigem. Valores novos se traduziriam em tarefas tecnicamente solúveis; a novidade seria a direção desse progresso, mas o próprio padrão de racionalidade permaneceria inalterado: 'A técnica, com universo de instrumentos, pode aumentar tanto a fraqueza como o poder do homem. No estágio atual, este se apresenta talvez como mais impotente com relação ao seu aparato do que jamais o fora antes.” 'Habermas, Jürgen. “Técnica e ciência enquanto 'ideologia””; p. 318-319. No entanto, parece-me mais condizente com o texto marcuseano precisar a distinção conceitual apresentada por Douglas Kellner entre as noções de tecnologia moderna e de técnica. Dessa forma, é necessário explicitar a diferença entre os papeis desempenhados pelos instrumentos técnicos da ciência e da produção material e, por outro lado, a interpretação marcuseana do modo de produção capitalista em sua totalidade. Segundo Kellner: “Ele faz distinção entre 'tecnologia' (definida 'como modo de produção, como a totalidade de instrumentos, dispositivos e invenções que caracterizam a era da máquina’) e ‘técnica’ (definida como os instrumentos e as práticas 'da indústria, transporte, comunicação’) para distinguir o sistema de dominação tecnológica de instrumentos técnicos e seus usos. Marcuse, assim, distingue tecnologia como uma 'forma de organizar e perpetuar (ou modificar) as relações sociais, uma manifestação do pensamento e dos padrões de comportamento dominantes, um instrumento de controle e dominação' contrastada à técnica, que se refere a técnicas de produção e a instrumentos como carros ou computadores. Enquanto a primeira constitui para Marcuse um sistema de dominação tecnológica, ele afirma que estas últimas podem elas mesmas 'promover tanto o autoritarismo quanto a liberdade, tanto a escassez quanto a abundância, tanto o aumento quanto a abolição do trabalho árduo’.” Kellner, Douglas. “Tecnologia, guerra e fascismo: Marcuse nos anos 40”; p. 27. 
Sua produtividade é destruidora do livre desenvolvimento das necessidades e faculdades humanas; sua paz, mantida pela constante ameaça de guerra; seu crescimento, dependente da repressão das possibilidades reais de amenizar a luta pela existência individual, nacional e internacional. Essa repressão, tão diferente daquela que caracterizou as etapas anteriores, menos desenvolvidas, de nossa sociedade, não opera, hoje, de uma posição de imaturidade natural e técnica, mas de força. As aptidões (intelectuais e materiais) da sociedade contemporânea são incomensuravelmente maiores do que nunca dantes - o que significa que o alcance da dominação da sociedade sobre o indivíduo é incomensuravelmente maior do que nunca dantes. A nossa sociedade se distingue por conquistar as forças sociais centrífugas mais pela Tecnologia do que pelo Terror, com dúplice base numa eficiência esmagadora e num padrão de vida crescente. ${ }^{351}$

Assim, em forte contraste com o infindável número de mercadorias que ela é capaz de prover, alternativas escassas germinam no interior dessa sociedade afluente. De acordo com Marcuse, o imperativo de desperdiçar suas capacidades técnicas e econômicas a fim de preservar os fundamentos da opressão social encontra um número bastante reduzido de saídas. O seu sucesso, na realidade, depende daquela combinação entre as características do estado beligerante e do estado de bem-estar social ${ }^{352}$.

A crescente produtividade do trabalho, o aumento do índice de natalidade - sobretudo o da população subjacente -, uma permanente economia de defesa, a integração político-econômica dos países capitalistas centrais e a intensificação das suas relações com as áreas economicamente subdesenvolvidas são condições materiais imprescindíveis para esse objetivo. Constrói-se uma espécie de círculo vicioso por meio do qual o fortalecimento do poderio militar das nações e a crescente capacidade produtiva da indústria parecem se requerer continuamente. Não para vencer uma batalha específica ou para superar os impasses gerados pela carência material, mas sim para estimular indefinidamente uma engrenagem que se impõe pelas necessidades que ela mesma produz

351 Marcuse, Herbert. A ideologia da sociedade industrial; p. 14.

352 Marcuse também examina as perspectivas de contenção da transformação social na sociedade soviética. Embora elas apresentem grandes similitudes com as presentes no campo capitalista, a base socialista da produção introduziria uma diferença decisiva. A separação entre os produtores imediatos e o controle sobre os meios de produção foi criada pelo poder e decisão políticos num breve "período heroico” da revolução bolchevique. Dessa forma, ela não surge imediatamente do próprio processo de produção, mas é incluída exteriormente e, ainda mais relevante, pode ser superada sem explodir as instituições básicas da sociedade. Porém, malgrado essa distinção, Marcuse afirma que a poderosa resistência oferecida pela "burocracia entrincheirada” parece não dar margem para essa possibilidade. Segundo Marcuse: “Não há razão alguma para se pressupor que progresso técnico mais nacionalização favorecerão a liberação e a libertação 'automáticas’ das forças de negação. Pelo contrário, a contradição às crescentes forças produtoras e sua organização escravizadora - abertamente admitida como uma das características do desenvolvimento socialista soviético até por Stálin - tem mais probabilidade de se aplanar do que de se agravar. Quanto mais os dirigentes forem capazes de entregar os bens de consumo, tanto mais firmemente a população subjacente estará atada às diversas burocracias dirigentes.” Idem. A ideologia da sociedade industrial; p. 57-58. 
e abrandar as malfadadas consequências acarretadas pela irracionalidade de sua própria perpetuação. Segundo Marcuse:

Mas o conflito contínuo entre as aptidões produtivas da sociedade e sua utilização destrutiva e opressiva pediria esforços intensificados para impor as exigências do aparato à população - livrar-se do excesso de capacidade, criar a necessidade de comprar as mercadorias que devem ser lucrativamente vendidas e o desejo de trabalhar para a sua produção e promoção. O sistema tende, assim, tanto para a administração total como para a dependência total da administração pelo domínio da gerência pública e privada, reforçando a harmonia preestabelecida entre os interesses do grande público++ e das corporações privadas e os dos fregueses e servidores. Nem a nacionalização parcial nem a participação aumentada dos trabalhadores da gerência e dos lucros alterarão por si este sistema de dominação - enquanto o próprio trabalho permanecer uma força sustentadora e afirmativa. ${ }^{353}$

Embora fomente vigorosamente um comportamento de tal tipo, não se trata meramente de uma sociedade unidimensional. As satisfações que ela é capaz de promover devem ser comparadas com aquilo que se poderia realizar. Para Marcuse, é possível pensar critérios eminentemente históricos a fim de elaborar uma crítica objetiva do ordenamento social.

Se não há qualquer instância que possa legitimamente decidir acerca do conteúdo da vida social e privada dos indivíduos, também é verdade que os homens somente estão aptos para essa responsabilidade na medida em que eles sejam realmente livres. Caso suas vontades mais íntimas sejam impostas de forma heterônoma, sua participação política se restrinja a escolhas secundárias e se mostre impotente ante os temas mais candentes ou, ainda, suas atividades práticas obedeçam aos ditames do processo de autovalorização do capital não se é permitido conceber os objetivos visados pelos indivíduos como algo que lhes surja espontaneamente. A democrática eleição dos senhores não abole a escravidão dos que sobrevivem sob a labuta e o temor ${ }^{354}$.

Desse modo, o desenvolvimento técnico e operacional alcançado e as suas conquistas culturais e intelectuais devem ser utilizados para dissolver a administração total que restringe sistematicamente a liberdade e o tempo dedicado ao cultivo e ao desenvolvimento das faculdades humanas, orientar a produção de mercadorias e dos serviços para corresponderem, quantitativa e qualitativamente, às verdadeiras necessidades individuais vitais e promover nos sujeitos modernos 
as condições intelectuais - tanto conscientes quanto inconscientes - de compreensão e percepção real das possibilidades de autodeterminação $0^{355}$. Em O homem unidimensional:

Os setores mais avançados da sociedade industrial ostentam completamente esses dois fatores: a tendência para a consumação da racionalidade tecnológica e esforços intensos para conter essa tendência no seio das instituições estabelecidas. Eis a contradição interna dessa civilização: o elemento irracional de sua racionalidade. É o totem de suas realizações. A sociedade industrial que faz suas a tecnologia e a ciência é organizada para a dominação cada vez mais eficaz do homem e da natureza, para a utilização cada vez mais eficaz de seus recursos. Torna-se irracional quando o êxito desses esforços cria novas dimensões de realização humana. Organização para a paz é diferente de organização para a guerra; as instituições que serviram à luta pela existência não podem servir à pacificação da existência. A vida como um fim é qualitativamente diferente da vida como um meio. ${ }^{356}$

Todavia, a capacidade de produzir mais e melhor o mesmo tipo de vida aplaina os conflitos e os antagonismos sociais. Entre a classe trabalhadora, a antiga contradição viva das sociedades modernas, nota-se consequências diretas desse novo arranjo socioeconômico. A interpretação crítica das sociedades capitalistas não pode se furtar à tarefa de repensar suas categorias. Conforme afirma Marcuse, Marx construiu suas elaborações teóricas em uma época na qual o trabalho realizado pelo proletariado era indissociável da extenuação física e da miséria econômica. Mesmo quando se empregava a maquinaria, os operários vivenciavam uma rotina bárbara e desumanizante ao se submeterem às condições aviltantes da compra e da venda de sua força de trabalho.

Ao se perpetuar nas sociedades industriais avançadas a exploração em moldes capitalistas, a velha fadiga muscular fora substituída pelas - não menos condenáveis - tensão psicológica, pela padronização das atividades e pela enervante rotina. Em ambos os casos, os nocivos efeitos desencadeados explicitam a irracionalidade constituinte das sociedades capitalistas. Porém, a mecanização intensiva modificou a atitude dos trabalhadores diante de suas condições de vida.

Ao menos nos países centrais do capitalismo, a execução de uma atividade no processo produtivo é relativamente menos extenuante e há um conjunto maior de mercadorias que compõe o valor da força de trabalho. Ademais, as habilidades e os saberes específicos implicados em determinada profissão, que tanto escravizava o trabalhador a uma determinada função nas cadeias produtivas quanto o tornava membro de uma classe que personificou a refutação da sociedade 
estabelecida, foram rompidas e reduzidas ao mínimo pelas imposições da máquina ${ }^{357}$. A complexidade inerente ao trabalho do antigo artesão é substituído pela obviedade das linhas de montagem. O proletariado torna-se plenamente substituível no exercício de suas funções - seja por outros trabalhadores, seja pela própria automação. Essa somatória de fatores fez com que as forças de oposição se amainassem e perdessem sua relevância social. Quando muito, elas conseguem preservar algumas de suas esperanças na crítica teórica das sociedades modernas ${ }^{358}$. Segundo Marcuse:

O proletário das etapas anteriores do capitalismo era na verdade um animal de carga, pelo trabalho de seu corpo na busca das necessidades e dos supérfluos da vida enquanto vivia na imundície e na pobreza. Ele era, assim, a negação viva de sua sociedade. Em contraste, o trabalhador organizado dos setores avançados da sociedade tecnológica vive essa negação menos conspicuamente e, como os demais objetos humanos da divisão social do trabalho, está sendo incorporado à comunidade tecnológica da população administrada. Mais ainda, nos setores da automatização mais coroados de êxito, uma espécie de comunidade tecnológica parece integrar os átomos humanos no trabalho. A máquina parece instilar certo ritmo de servidão nos operadores. ${ }^{359}$

Assim, dominação social transfigurada em administração técnica das coisas apresenta um aspecto formalmente racional. Levada a cabo com o auxílio de meios de controle tecnológicos, a atual integração social assume a aparência de ser a própria personificação da razão, tornando-se quase inquestionável. Talvez se pudesse até mesmo cogitar que a vasta rede de instituições repressivas dos estados, os antigos métodos de sujeitar a população à divisão social do trabalho meios de sustento, a distribuição da justiça, a polícia e as forças armadas ${ }^{360}$-, fosse dispensável em face do espírito adaptativo que se apodera dos homens ${ }^{361}$. A produtividade e a eficiência de suas

357 Ibidem; p. 45.

358 A esse respeito, Marcuse afirma: “A tentativa de recuperar o objetivo crítico dessas categorias e de compreender como o objetivo foi cancelado pela realidade social parece, logo de início, uma regressão da teoria ligada à prática histórica para o pensamento abstrato e especulativo: da crítica da Economia Política para a Filosofia. Esse caráter ideológico da crítica resulta do fato de a análise ser forçada a partir de uma posição 'externa' às tendências da sociedade, tanto positivas como negativas, tanto produtivas como destrutivas. A sociedade industrial moderna é a identidade penetrante desses opostos - é o todo que está em questão. Ao mesmo tempo, a teoria não pode ser meramente especulativa. Deve ser um ponto de vista histórico no sentido de dever basear-se nas aptidões da sociedade em questão.” Ibidem; p. 17-18.

359 Ibidem; p. 43-44.

360 Ibidem; p. 30.

361 Porém, é importante ressaltar que, para Marcuse, as sociedades industriais avançadas não abandonam definitivamente esses métodos. Prova de que essa integração não é tão poderosa e que os benefícios dessa sociedade afluente não são distribuídos de maneira equânime, Marcuse afirma: “Aqueles cuja vida é o inferno da Sociedade Afluente são mantidos na ordem por uma brutalidade que revive as práticas medievais e dos primórdios da era moderna. Quanto às outras criaturas não-privilegiadas, a sociedade cuida de sua necessidade de libertação satisfazendo às necessidades que tornam a servidão aceitável e talvez até mesmo imperceptível, e concretiza esse 
agências criam obstáculos para que a consciência humana se aperceba de sua servidão.

Essa nova sociedade e seus sóbrios procedimentos de controle mostram-se aptos a fortalecerem tendências que mantêm a união e a coesão social interna em parâmetros até então desconhecidos. A submissão da economia nacional aos interesses das grandes corporações, de um sistema mundial de alianças militares, de convênios monetários e de planos de desenvolvimento e de assimilação gradativa da classe dos trabalhadores porta-se como um poderoso mecanismo de estímulo à produção e ao pleno emprego. A intensa e totalizante mobilização contra o fantasma de um inimigo exterior - principalmente, o comunismo internacional, mas também, por vezes, outras potências capitalistas - desloca os conflitos internos dessas sociedades e sustenta essa forçada e repressiva harmonia com a produtividade crescente e a respectiva elevação do padrão de vida ${ }^{362}$. Segundo Marcuse:

A sociedade industrial recente aumentou, em vez de reduzir, a necessidade de funções parasitárias e alienadas (para a sociedade em seu todo, se não mesmo para o indivíduo). Os anúncios, as relações públicas, a doutrinação e o obsoletismo planejado não mais são custos improdutivos gerais, mas elementos dos custos básicos de produção. Para ser eficaz, tal produção de desperdício socialmente necessário exige a racionalização contínua - a utilização incessante de técnicas avançadas e ciência. Consequentemente, um padrão de vida crescente é o subproduto inevitável da sociedade industrial politicamente manipulada, uma vez ultrapassado certo nível de atraso. A produtividade crescente do trabalho cria um crescente produto excedente que, quer particular, quer centralmente destinado e distribuído, permite um consumo aumentado - não obstante o desvio aumentado da produtividade. Enquanto prevalecer essa constelação, ela reduzirá o valor de uso da liberdade, não havendo razão alguma para insistir na autodeterminação se a vida administrada for confortável e até "boa”. Este é o terreno racional e material para a unificação dos opostos, para o comportamento unidimensional. Sobre essa base, as forças políticas transcendentes dentro da sociedade são impedidas, e a transformação qualitativa parece possível somente do exterior. ${ }^{363}$

Ora, essa nova configuração dos imperativos da vida social transfigurou substancialmente aquilo que Marcuse identificava como o ponto cego de Weber. Porém, a sociologia weberiana consegue também revelar uma prodigiosa contemporaneidade.

Em certo sentido, ela acompanha a ratio que, despercebidamente, transforma-se no curso de seu desenvolvimento e subordina-se, por sua legalidade interna, à razão da dominação ${ }^{364}$. A

fato no próprio processo de produção.” Ibidem; p. 42.

362 Ibidem; p. 40.

363 Ibidem; p. 63.

364 Idem. “Industrialização e capitalismo na obra de Max Weber”; p. 124. 
retorcida imbricação entre a contingência da ascensão dos líderes carismáticos, a sufocante ubiquidade e a fria previsibilidade dos procedimentos das agências de dominação burocrática atestam mais um aspecto sui generis constituinte da razão ocidental. O oblíquo movimento da esfera política corresponderia à involuntária intrepidez dos conceitos weberianos de dominação e de liderança carismática. Apesar de apresentar-se com outro significado e com consequências distintas, o reiterado impulso da ratio de submeter-se a desígnios exteriores reaparece. Mais uma vez, ela soçobra diante de seu espelho - a irracionalidade do conjunto das sociedades modernas. Em “Industrialização e capitalismo na obra de Max Weber”:

Eis até que ponto a abstração de Max Weber se encontra saciada por seu material: ela emite o juízo racional acerca da sociedade mercantil racional. Contudo, em seu desenvolvimento esta tende a superar seus próprios pressupostos materiais - o empresário privado já não é mais o sujeito auto responsável da racionalidade econômica, e o "trabalho livre" já não é escravização imposta pela ameaça do "flagelo da fome”. A sociedade da troca em que tudo acontece com tanta liberdade e racionalidade se subordina à dominação de monopólios econômicos e políticos. O mercado e suas liberdades, cujo caráter ideológico Max Weber denunciou com muita frequência, se submetem a uma regulação assustadoramente efetiva, em que o interesse geral é incisivamente determinado e marcado pelos interesses particulares dominantes. Assim a reificação seria superada num mau sentido. Na separação dos meios de produção (Betriebsmitteln) em que Max Weber viu muito acertadamente uma necessidade técnica, converte-se numa subordinação do todo a seus gerentes calculistas. A racionalidade formal do capitalismo celebra seu triunfo nos computadores eletrônicos que calculam tudo independentemente de sua finalidade, que são empregados como instrumentos poderosos da política de manipulação e que calculam com probabilidade máxima as chances de lucros e de perdas - inclusive a chance de destruição do todo, com a anuência de uma população igualmente objeto de cálculo e obediente. A democracia de massas se torna plebiscitária, inclusive no plano econômico e científico: até mesmo ao escolherem seus líderes (Führer) as massas se encontram no "casulo da servidão". 365

\section{O “espírito coagulado” e suas ranhuras.}

O conceito weberiano de razão, investigado em suas manifestações abertas e encobertas, progressivas e regressivas, de acordo com Marcuse, encontra seu complemento necessário com o tema da dominação ${ }^{366}$. A imbricação desses dois termos corporifica-se de modo mais claro e preciso com a instituição de um amplo e complexo aparato de dominação, estruturado por uma organização universal de funcionários tecnicamente especializados - a moderna burocracia. Constituído em meio a um conjunto variado de práticas e instituições sociais, a influência de tais transformações 
espalha-se por todo o sistema da cultura material e intelectual das sociedades modernas.

Dando-lhe suporte e atuando incisivamente, a razão ocidental avançou sobre os mais distintos domínios da vida social. Essa racionalização não advém imediatamente da objetividade das coisas - não se trata de leis da física, mas a lei da sociedade ${ }^{367}$. Na verdade, ela é uma espécie de disposição subjetiva calcada em determinada formação social que age como dominação metódica, científica e racional sobre os sujeitos modernos, sobre as sociedades e sobre a natureza.

Nesse sentido, a forte coação exercida pelo espírito do capitalismo e por seu respectivo ascetismo intramundano sobre as inúmeras formas de práticas sociais, a pressão pela matematização progressiva do conhecimento, as exigências de provas empíricas factuais para a atividade intelectual, os critérios organizativos e os paradigmas operacionais vigentes na produção material de mercadorias e, sobretudo, a rigorosa disciplina atuante no interior das fábricas compõem os principais aspectos da transição de uma razão teórica específica ao Ocidente para a razão prática peculiar à configuração histórica da modernidade. Segundo Marcuse:

Na base dessa racionalidade reina a abstração, que, ao mesmo tempo teórica e praticamente, obra da organização científica $e$ social, determina o período do capitalismo: pela redução de qualidade em quantidade. Como funcionalização universal (tal como se expressa economicamente no valor de troca) ela se torna pressuposto de eficiência calculável - eficiência universal, na medida em que a funcionalização possibilita domínio calculável sobre a natureza e sobre os homens. Assim a razão focalizada por Max Weber se revela como razão técnica: produção e transformação de material (humano e de coisas) por meio do aparato construído metódica e cientificamente com vistas à eficiência calculável, cuja racionalidade organiza e controla coisas e homens, fábricas e burocracia de funcionários, trabalho e tempo livre. ${ }^{368}$

Porém, a questão mais fundamental e, conforme afirma Marcuse, não resolvida pela sociologia weberiana seria ainda anterior. Diante do umbral de converter essa forma histórica da razão em instrumento da libertação dos homens ${ }^{369}$, Weber sucumbiu à dialética que marca a relação entre racionalidade e irracionalidade nas sociedades modernas.

É certo que, quando fora capaz de produzir uma autocrítica aos pressupostos materiais e teóricos das sociedades modernas e ao próprio conjunto de seu pensamento, a sociologia weberiana

367 Idem. O homem unidimensional; p. 31.

368 Marcuse, Herbert. “Industrialização e capitalismo na obra de Max Weber”; págs. 116-117.

369 Ibidem; p. 132. 
fomentou um discurso radical ao denunciar a ratio por seus termos imanentes. A civilização forjada a partir das condições sociais, políticas e econômicas no final da Idade Média, cujo espírito desenvolveu-se por uma racionalidade pretensamente formal imposta à conduta econômica e às instâncias psíquicas dos pregadores do progresso capitalista, revela-se por meio das categorias weberianas como uma nova forma de servidão ao abstrair, de maneira generalizada e impiedosa, o próprio homem e suas necessidades.

Não obstante, justamente por conta de suas aspirações em torno da neutralidade do conhecimento nas ciências sociais, Weber teria se mantido preso a valores eminentemente burgueses em suas análises sobre o capitalismo moderno. Em alguma medida, o autor de ES anteciparia os desdobramentos das sociedades modernas no período pós-liberal. De forma direta, o embaraço do desenlace posterior já estaria contido nos pressupostos não problematizados que rondam a antessala de seu pensamento - o denso nevoeiro no qual o seu conceito de ratio está envolto. A neutralidade da razão revela-se falsa tão logo se constate sua dependência aos pressupostos materiais exteriores a ela. Mais do que um simples descuido subjetivo, tal parcialidade brota da natureza da vida social moderna.

Pois, conforme afirma Marcuse, aquilo que a dialética materialista concebe como o primeiro ato histórico - isto é, a produção dos meios para a satisfação das necessidades, a produção da vida material ${ }^{370}$ - é hipostasiado e apreendido como uma razão necessária por Weber ${ }^{371}$. Embora haja esforços reiterados em seu pensamento de diferenciar a razão formal ocidental dos tipos distintos de racionalidade material pertencentes a outras formações sociais, cujo sustento econômico dos seus membros seria derivado de determinados postulados ético-normativos, os conceitos weberianos também estariam vinculados intrinsecamente às precondições materiais e ideias de reprodução capitalista da vida e da riqueza coletivas. Segundo Marcuse:

O conceito weberiano de razão até agora foi definido de modo "formal": como a abstração quantificadora, abstração de todas as particularidades, a abstração que possibilita a eficiência universalmente calculável do aparato capitalista. Mas agora se apresentam os

370 Marx, K e Engels, F. A ideologia alemã; p. 33.

371 Marcuse, Herbert. "Industrialização e capitalismo na obra de Max Weber”; p. 113. 
limites da razão formal: nem o para que da construção científico-técnica, nem a matéria da construção (seus sujeitos e objetos) podem ser deduzidos a partir do conceito de razão; rompem de antemão o conceito formal "axiologicamente neutro" da ratio. Na racionalidade capitalista, tal como Max Weber a analisa, esses elementos previamente dados à razão, que a limitam materialmente, aparecem em dois fatos históricos:

1. o sustento dos homens - o objetivo da prática econômica - ocorre no plano das chances calculadas de ganho da economia privada, isto é, no âmbito do lucro do empresário individual e das empresas individuais;

2. portanto a existência dos homens a serem sustentados é dependente das chances de ganho da empresa capitalista - uma dependência que adquire corpo de modo extremo no trabalho "livre” existente à disposição do empresário. ${ }^{372}$

A ratio passaria, então, a ser pensada como pura técnica, como aquilo que supõe estar sob influxo de reações mecânicas de um organismo meramente funcional. Todavia, se há algum acerto sobre a monotonia do conjunto, a conceitualização weberiana não se mostra afeita à desvincular-se da sua vocação política. Uma racionalidade concebida como técnica, ou seja, como uma simples formulação de meios para atingir fins que lhe são sempre exteriores estará sujeita aos imperativos advindos da estrutura de produção de mercadorias ${ }^{373}$.

Essa base material que lhe dá origem e seus objetivos selam o destino da ratio e conformam o conjunto das sociedades segundo seus caprichos - a paralisia espalha-se por todo tecido social. Por tais meandros, erige-se uma figura inédita de domínio social e político. Comandados por aquilo que se apresenta como necrose, os sujeitos modernos, as instituições sociais, a vida cultural e política são completamente submetidos a critérios tais como os de eficiência maximizada, de disciplina, de previsibilidade e de calculabilidade.

Longe de representar uma etapa superior de civilização, essa hodierna maneira de administrar os homens e as coisas repisa velhos chavões em uma gramática aparentemente neutra. As antigas práticas e instituições abertamente violentas de domínio e de controle social são substituídas por formas racionalizadas e reificadas de comando. É bem verdade que o seu modo de atuação é menos hostil. Não obstante, o seu caráter permanece politicamente orientado. As

\section{Ibidem; p. 117.}

373 A esse respeito, segundo Gandesha: "Here, then, the ideological nature of technology does not simply come from the outsite - that is to say, in the specific uses of which tecnology is put - as Marcuse suggests erlier, but rather constitutes its innermost essence. What this means is that, as a project, technological reason is the principal means in and through which human beings and things are constituted; in short, it is the way in which the world is revealed and made available for domination. Thus, we find in the passage an ambivalent justaposition of technology as neutral instrumentality, fettered only by society's production relations, on the one hand, and technology as a world-disclosing project on the other.” Gandesha, Samir. "Marcuse, Habermas and technology”; págs. 195-196. 
verdadeiras necessidades humanas não são atendidas. Em seu lugar, hipostasiam-se valores, padrões de sociabilidade, formas de conduta e o próprio modo de produção e de distribuição da riqueza material. Segundo Marcuse:

A administração científico-especializada do aparelho como dominação racional-formal: eis a reificação (Verdinglichung) da razão - reificação como razão -, apoteose da reificação. Mas a apoteose se converte em sua negação, precisa se tornar sua negação. Pois o aparelho que impõe sua própria administração objetiva constitui ele próprio um instrumento, um meio - e não existe um meio "em si". Por mais produtivo, reificado que seja um aparelho, trata-se de um meio para um fim fora dele. No que concerne ao aparelho econômico do capitalismo: não basta focalizar a satisfação das necessidades como sendo esse fim. O conceito é demasiado geral, demasiado abstrato no mau sentido. Pois, como o próprio Max Weber constatou, a satisfação das necessidades é muito mais um produto lateral, de acompanhamento, do que um fim do agir econômico capitalista - um produto de acompanhamento subordinado ao lucro. ${ }^{374}$

Apesar de ser concebida como algo etéreo, tudo se passa como se o conceito weberiano de razão ocidental trouxesse reiteradamente as marcas de suas origens e de seus alicerces. O mais grave é que sua procedência continua a lhe impingir travas e barreiras. A esse respeito, a concepção weberiana de ciência seria paradigmática. Malgrado a reivindicação de autonomia, a sua natureza instrumental impede qualquer independência em relação aos pressupostos mais elementares da sociabilidade moderna.

Filhotes de uma mesma ninhada, o modelo weberiano de ciência assumiria o mesmo papel de dependência reservado à economia no debate acerca da política de autoconservação do Estado alemão. Concretamente, tal entendimento a respeito da atividade intelectual traria de forma latente as escolhas políticas de Weber. Se, de acordo com Weber, diante dos desafios históricos da Alemanha pós-Bismarck as políticas econômicas deveriam ser concebidas a partir da expectativa de preservação da unidade nacional, a exigência de imparcialidade que recai sobre o ideal de ciência weberiano traz em seu bojo a esperança na perenidade das estruturas de pensamento modernas e da base da produção material do capitalismo liberal. A sua teoria da neutralidade axiológica, que ambiciona uma ciência livre a fim de submetê-la à influência de valores externos, mantém-se atrelada a condicionamentos filosóficos, histórico-sociológicos e políticos modernos ${ }^{375}$. A ebulição 
crítica do pensamento é arrefecida e a elaboração teórica tende a se conformar com uma especialização sem precedentes e com a crescente impotência em sua capacidade de recusa e de rebeldia ao existente. Segundo Marcuse:

Se já o Discurso de posse subordinada de maneira provocativa a ciência da economia à política, à luz da obra conjunta de Weber esse tour de force se revela como sendo a lógica interna de seu método: a ciência de vocês deve permanecer "pura”, só assim vocês poderão permanecer fiéis à verdade. Mas essa verdade obriga vocês a aceitar o que a partir “do exterior" determina os objetos da ciência de vocês; sobre isso vocês não têm nenhum poder. A neutralidade axiológica de vocês é tão necessária quanto ilusória: a neutralidade só é efetivamente real quando provida do poder de evitar interferências; quando não, ela se torna vítima e auxiliar de todo poder que pretende utilizar. ${ }^{376}$

Porém, o ápice desse contágio e desse empecimento cristaliza-se em um outro aspecto.

Mesmo quando inquirido em termos meramente formais, o conceito weberiano de capitalismo moderno seria bem menos racional do que aparenta à primeira vista. As agruras inerentes ao salto mortal das mercadorias, a condução da economia a cargo da iniciativa privada de agentes individuais e, consequentemente, a ausência de coordenação e de planificação centralizadas dos investimentos de recursos e de mão de obra apresentam sensíveis déficits de previsibilidade. Diante das transformações socioeconômicas já prenunciadas no tempo de Weber e que foram levadas a cabo com o capitalismo avançado, uma tal compreensão do capitalismo vê a sua racionalidade ser desafiada ordinariamente pela realidade histórica.

Imaginado como modelo permanente do comportamento subjetivo moderno, o homo economicus weberiano equivoca-se em seus cálculos cotidianos, mostra-se indeciso sobre o destino de suas aplicações financeiras e, por fim, paralisa-se ante a complexidade e a desmesura do movimento dos capitais de uma economia pós-liberal. Segundo Marcuse:

Evidentemente, de acordo com essa definição uma economia totalmente planificada, e portanto uma economia não capitalista, no sentido da racionalidade formal, seria mais racional do que a capitalista, que traz em si o limite de sua calculabilidade no interesse particular do empreendimento privado e na "liberdade" do mercado (seja qual for a sua regulamentação). Quanto Max Weber afirma que uma tal economia de mercado planejada seria um retrocesso ou até realisticamente impossível, ele o faz inicialmente por razões tecnológicas: na moderna sociedade industrial a separação dos trabalhadores em relação aos meios de produção (Betriebsmittel) se tornou uma necessidade técnica, que exige direção e controle individual-privados dos meios de produção, isto é, o domínio na unidade produtiva do empresário pessoalmente responsável. Assim o fato histórico material do empreendimento capitalista privado se converte (no sentido de Max Weber) em elemento

376 Ibidem; p. 125. 
estrutural formal do capitalismo e do próprio agir econômico racional. ${ }^{377}$

Por outro lado, há uma miríade de possibilidades utópicas que as sociedades modernas frustram, e a sociologia weberiana faz vistas grossas. A pretensa formalidade da razão ocidental e a imparcialidade e naturalidade pela qual as suas instituições e suas práticas sociais aparecem em sua imediaticidade são construções históricas e, como tais, suscetíveis a toda sorte de transformações e rupturas - sobretudo as revolucionárias. É certo que, para Marcuse, a razão ocidental e a moderna tecnologia capitalista são travejadas internamente por condicionamentos políticos e sociais e por regressões intelectuais.

Embora a moderna técnica crie as condições para outro patamar de civilização e de cultura $^{378}$, ela incorpora e dá vazão a um projeto de dominação sociopolítica sobre a natureza e sobre os homens. A promoção de seu fim último e mais urgente - a conservação do status quo e a reprodução ampliada do capital - solapam as esperanças. A racionalidade formal nasceu embrenhada nas relações de produção capitalistas. Nessa sua condição de ser mero instrumento, a razão vê-se impedida de propor para si conteúdos progressistas. Segundo Marcuse:

Enquanto a razão política, a razão técnica é histórica. Se a separação dos meios de produção é necessidade técnica, a servidão por ela organizada não o é. Com base em suas próprias conquistas - a mecanização produtiva e calculável -, esta separação adquire a

377 Ibidem; p. 122-123.

378 Penso que essa noção não deva ser compreendida como uma antecipação de uma crítica social erigida sobre uma concepção dualista de trabalho e interação. Pois, contrariamente ao que afirma Habermas em "Técnica e ciência enquanto 'ideologia'”, Marcuse sublinha a indissociabilidade e complementariedade entre a moderna tecnologia e as esferas da política e da cultura capitalistas. Menos do que sugerir um novo paradigma de racionalidade social advinda das interações simbólicas entre os sujeitos, Marcuse parece apontar para uma crítica que pensa e se dirige contra a totalidade da vida social. Segundo Habermas: "Marcuse tem em mente uma atitude alternativa para com a natureza, mas não é possível derivar dessa atitude a ideia de uma nova técnica. Em vez de tratar a natureza como objeto passivo de uma possível manipulação técnica, podemos dirigir-nos a ela como a um parceiro numa possível interação. Em vez da natureza explorada podemos ir em busca da natureza fraterna. Ao nível de uma intersubjetividade ainda incompleta, podemos atribuir a subjetividade aos animais, às plantas e até mesmo às pedras e comunicar-nos com a natureza, em vez de nos limitarmos a trabalha-la, quebrando a comunicação.” Habermas, J. “Técnica e ciência enquanto 'ideologia””; p. 318. A esse respeito, Gandesha associa as críticas de Habermas ao pensamento de Marcuse às diferentes interpretações que esses autores fizeram da sociologia weberiana. Segundo Gandesha: “Thus, Marcuse criticizes Weber for the construal of rationaliztion that only gains its own sinister autonomy and works behind the backs of historical individuals precisely because, as a historical possibility, the mediation of subjective and objective forms of reason is closed off. For Habermas, by contrast, the short-comings of Weber's account of modernity lie in the refusal to recognize that the extension of Zweckrationalität is accompanied by a simultaneous differentiation of value spheres no longer rooted in traditional or religioys world-views, and the correspondig possibility of a 'rationalization' of the Lebenswelt. Thus, Marcuse's and Habermas's critique are almost exactly inverse imagens of each other. While Marcuse argues for an extension of the concept of labor as the crucial mediation of subject and objetct, Habermas argues for its foreshortening in an account of the rationalization of the symblolically mediated action fo the Lebenswelt that is attendant upon the spread of 'purposive-rationality.'”. Gandesha, Samir. “Marcuse, Habermas und technology; págs. 197-198. 
possibilidade de uma racionalidade qualitativamente diferente, em que a separação dos meios de produção se converte em separação dos homens do próprio trabalho socialmente necessário mas que o destrói. No estágio da produção automática administrada pelos homens assim libertados, as finalidades formal e material já não seriam necessariamente "antinômicas" - e nem a razão formal se imporia "indiferentemente" por entre e por cima dos homens. Pois enquanto "espírito coagulado" a máquina não é neutra; a razão técnica é a razão social em cada caso dominante; ela pode ser transformada em sua própria estrutura. Enquanto razão técnica ela só pode ser convertida em técnica da libertação. ${ }^{379}$

A moderna opressão capitalista, portanto, só poderia ser superada mediante a supressão profunda de suas formas de sociabilidade e de sua organização da produção material de mercadorias. Somente assim a humanidade deixaria de ser um apêndice da máquina e conduziria a vida social conforme critérios substantivos de racionalidade.

Todavia, as sociedades modernas orientaram-se por um rumo perverso. O seu caráter histórico petrificou-se na consciência dos indivíduos e, em velocidade de cruzeiro, ela serpenteia com uma nova dinâmica - a desbragada aceleração da economia. Diante de tal açodamento, nem mesmo a mais primitiva forma de organização da produção de mercadorias está preservada.

O metabolismo econômico das sociedades industriais avançadas coloca em síncope a figura do empresário capitalista individual, a desregulamentação dos mercados e altera o sentido das ameaças e das restrições do pauperismo que, outrora, assombraram a classe dos trabalhadores de maneira brutal. Embora ainda se mantenha indispensável para a produção de valor, também o trabalho realizado pelo proletariado sofre a concorrência da automação da produção e do desenvolvimento tecnológico na obtenção do lucro renovado. Ante essa relação qualitativamente distinta entre trabalho vivo e trabalho morto, a produtividade é cada vez mais determinada pelas máquinas e não unicamente pelo rendimento individual do trabalhador ${ }^{380}$. Em A ideologia da sociedade industrial:

Essas alterações no caráter do trabalho e nos instrumentos de produção mudam a atitude e a consciência do trabalhador, o que se torna manifesto na "integração social e cultural" do trabalhador na sociedade capitalista, amplamente discutida. Será uma modificação somente na consciência? A resposta afirmativa, com freqüência dada pelos marxistas, parece estranhamente inconsistente. Será tal alteração fundamental na consciência compreensível sem que se admita uma modificação correspondente na "existência social"? Ainda que se admita algo grau de independência ideológica, os laços que unem essa mudança à transformação dos processos produtivos militam contra essa

379 Marcuse, Herbert. "Industrialização e capitalismo na obra de Max Weber”; p. 133-134.

380 Marcuse, Herbert. A ideologia da sociedade industrial; p. 46. 
interpretação. A assimilação nas necessidades e aspirações, no padrão de vida, nas atividades das horas de lazer, na política se deriva de uma integração na própria fábrica, no processo material de produção. ${ }^{381}$

Todavia, a questão não se resume a essas transformações econômicas objetivas. Conjuntamente a tais mudanças, atua um correlato esvaziamento interno da subjetividade dos indivíduos modernos. O período de produção em massa de mercadorias e bens culturais e da centralização das formas de controle social é dependente de uma operação que torna os homens suscetíveis a serem recompensados dessa maneira. Não há justificativa puramente racional para que a jornada de trabalho, que poderia ser reduzida de forma drástica consoante as capacidades técnicas e científicas, prolongue-se para além de um tempo mínimo necessário.

Quando isso ocorre, é sinal de que foram falseados os objetivos racionais dos homens. De acordo com Marcuse, menos do que indicar um avanço civilizacional verdadeiro, o fato dos trabalhadores e de seus patrões partilharem os mesmos gostos e disposições por programas televisivos e lugares pitorescos, da datilografa vestir-se de maneira tão atraente quanto as filhas da grande burguesia e de todos os indivíduos em buscar informações nos mesmos veículos de mídia é índice de que a satisfação das necessidades que preservam o status quo se espraia inclusive entre aqueles que ficam apenas com uma ínfima parte do produto social ${ }^{382}$. Se só é plausível estabelecer negativamente quais seriam os reais interesses e objetivos dos homens modernos, a atual impostura se desmascara em si mesma. Segundo Marcuse:

\footnotetext{
“Falsas” são aquelas superimpostas ao indivíduo por interesses sociais particulares ao reprimi-lo: as necessidades que perpetuam a labuta, a agressividade, a miséria e a injustiça. Sua satisfação pode ser assaz agradável ao indivíduo, mas a felicidade deste não é uma condição que tem de ser mantida e protegida caso sirva para coibir o desenvolvimento da aptidão (dele e de outros) para reconhecer a moléstia do todo e aproveitar as oportunidades de cura. Então, o resultado é euforia na infelicidade. A maioria das necessidades comuns de descansar, distrair-se, comportar-se e consumir de acordo com os anúncios, amar e odiar o que os outros amam e odeiam, pertence a essa categoria de falsas necessidades. ${ }^{383}$
}

Sob esse influxo, os sujeitos modernos contêm também internamente as possibilidades de transformação qualitativa das sociedades. De acordo com Marcuse, o conceito de indivíduo, 
formado entre os séculos XVI e XVII e estreitamente ligado à noção de autonomia que nenhuma autoridade externa poderia desrespeitar, estilhaçou-se com a racionalidade tecnológica. Por meio de um comportamento difundido para além das fábricas, essa racionalidade estabeleceu padrões de julgamento e estimulou atitudes que levaram os sujeitos a introjetar os ditames do mecanismo tecnológico ${ }^{384}$. O modelo advém da relação entre o homem e a máquina. Quando se manipula uma máquina, nota-se que a fiel obediência às instruções de uso é condição necessária para se obter os resultados esperados. Esse treino intensivo em apreender o mundo a partir de relações mecânicas arrefeceu todo o esforço libertador do pensamento e deteve a razão à manutenção incondicional do aparato sociopolítico.

Por mais uma vez, a irracionalidade social ressurge como força indômita. Mesmo sendo verdadeira a assunção de que a atual sociedade seja marcada pela opulência, as recompensas e as mercadorias que ela fornece continuam muito aquém da sua potencialidade material. De maneira implacável, as conquistas e os benefícios dessa sociedade afluente são acompanhados por decepções recorrentes. Em “Algumas implicações sociais da tecnologia moderna”:

As relações entre os homens são cada vez mais mediadas pelo processo da máquina. Mas os equipamentos mecânicos que facilitam o contato entre os indivíduos também interceptam e absorvem sua libido, desta forma distanciando-a do reino por demais perigoso no qual o indivíduo se encontra livre da sociedade. O homem médio dificilmente se importa com outro ser vivo com a intensidade e persistência que demonstra por seu automóvel. A máquina adorada não é mais matéria morta, mas se torna algo semelhante a um ser humano. E devolve ao homem o que ela possui: a vida do aparato social ao qual pertence. (...). Quanto mais racionalmente o indivíduo se comporta e quanto mais devotamente se ocupa de seu trabalho racionalizado, tanto mais sucumbe aos aspectos frustrantes desta racionalidade. Ele está perdendo sua habilidade de abstrair da forma especial em que a racionalização é levada a efeito e está perdendo a fé em suas potencialidades não realizadas. ${ }^{385}$

\section{O capitalismo moderno e sua política.}

De modo agônico e inquietante, as ranhuras da razão ocidental ressurgem na trama dos conceitos weberianos destinados a compreender a política moderna. Além romper qualquer ocultação ideológica ao revelar o caráter ilusório pertencente à moderna democracia de massas,

384 Idem. “Algumas implicações sociais da tecnologia moderna”; p. 77.

385 Ibidem; p. 81-82. 
sobretudo em sua falsa igualização e assimilação das diferenças e dos contrastes entre as classes sociais ${ }^{386}$, eles vão adiante e são capazes de revelar um segredo ainda mais recôndito das sociedades capitalistas.

De acordo com Marcuse, tanto nos acontecimentos políticos referentes à Alemanha pós-Bismarck quanto nos relativos ao destino do Ocidente ${ }^{387}$, a interpretação weberiana coloca-se diante de antinomias características não apenas de um tipo ainda ascendente de dominação social e política. Não se trata simplesmente dos avanços e dos recuos peculiares a uma etapa prévia de consolidação das novas instituições e práticas de comando.

Segundo a sua definição, a moderna burocracia deveria se portar conforme princípios de calculabilidade, de previsibilidade e de disciplina. Porém, aquilo que pretende ser o governo do aparato burocrático e dos seus funcionários especializados não se conserva assim por muito tempo. Por força imanente de sua racionalidade, a dominação burocrática tende a se subordinar a um centro de poder alheio. No que pese o funcionamento normal e esperado de suas regras e de seus procedimentos, nota-se um recorrente e inevitável apelo a formas distintas de organização e de administração da esfera política.

O problema, portanto, já não seria mais a base material das sociedades modernas que, concebida como uma privação de ordem técnica, escamoteia o viés político e a historicidade da civilização e da razão ocidentais. Apesar de se correlacionar com fundamentos socioeconômicos capitalistas, o fenômeno perturbador da ordem perscrutado é o fato da dominação burocrática perder reiteradamente o seu chão, e não conseguir cumprir integralmente o seu propósito - a administração plenamente racionalizada lança mão de estratégias irracionais para se perpetuar ${ }^{388}$. Segundo Marcuse:

\section{Ibidem; p. 128.}

\section{Ibidem; p. 113.}

388 Convém destacar que, para Marcuse, embora a ratio se organize por meio de procedimentos comuns baseados na dominação, na calculabilidade e na previsibilidade, e avance com perversidade sobre todos os domínios da vida social, em cada uma das esferas da sociedade suas contradições e antinomias são específicas. Seja no nível mais abstrato da razão ocidental, seja mais concretamente na política, na economia e na constituição dos sujeitos modernos, o essencial é compreender como a ratio se comporta em cada caso particular. Dessa forma, é possível contestar leituras que pretendem sublinhar certo caráter totalizante e unidimensional do pensamento de Marcuse. 
Necessário e “formal-racional”, enquanto ainda não se pode dispensar as pessoas vivas como consumidores (como produtores já em parte já se tornaram desnecessárias), contudo já hoje se vende muito para armazéns - destruição e uma existência humana embaixo da terra. Mas, quando a administração burocrática em toda a sua racionalidade permanece meio e, portanto, dependente, então, enquanto racionalidade, ela tem seu próprio limite: a burocracia se subordina a um poder extra-burocrático e superior à burocracia - a um poder "alheio à empresa produtiva". E se a racionalidade se concretiza na administração e somente nela, então o poder legislador precisa ser irracional. O conceito weberiano de razão termina no carisma irracional. ${ }^{389}$

O sintoma da descontinuidade e da opacidade inerentes à esfera política surge logo nos primeiros escritos de Weber. Para Marcuse, o seu discurso de posse de Freiburg está impregnado por uma turva concepção que enxerga somente na politica imperialista a condição para a pacificação possível - se é que esse termo se emprega - no interior das nações.

Diante desse cenário, a aposta de Weber é atrelar as modernas formas de dominação ao desenvolvimento da grande indústria em território alemão a fim de garantir a independência requerida para a sua sobrevivência em um contexto de acirrada disputa internacional e também superar os impasses da antiga ordem feudal-conservadora, promover a modernização socioeconômica, destravar a democratização e a racionalização da política e conter as ameaças da revolução e do socialismo ${ }^{390}$. As antinomias decorrentes dessa combinação são frutos de uma sociedade que deveria ser emancipada de suas restrições econômicas e de suas contradições sociais, porém se mantém presa a elas para preservar a antagônica ordem social estabelecida e a condução da economia conforme o ritmo - ao mesmo tempo, veloz e mal intencionado - da produção de mercadorias.

Em vez de ultrapassar os seus limites internos, esta razão formalizada e o quadro técnico administrativo da burocracia moderna que ela fundou sucumbem ao irracional e, de antemão, denunciam qualquer tipo de racionalidade histórica qualitativamente distinta. De acordo com Marcuse, a desconfiança e o ar debochado pelos quais Weber julgava as experiências e os esforços de transformação da configuração do poder - tais como república de conselhos, governo de convenções e comitês de salvação ${ }^{391}$ - são tributárias dessa acanhada compreensão do que é 389 Marcuse, Herbert. “Industrialização e capitalismo na obra de Max Weber”; p. 126-127. 
racional. Pensar a distribuição das riquezas materiais como uma libertação da economia - isto é, que a luta pela sobrevivência não mais controle o comportamento dos sujeitos -, as disputas políticas como libertação da política sobre a qual os indivíduos não têm a menor influência e a autonomia intelectual como libertação do pensamento das amarras da manipulação e da doutrinação

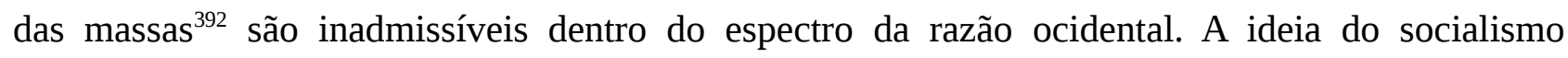
coloca-se em rota de colisão com tal arranjo.

Porém, isso ainda não é tudo. Entre sobressaltos e tropeções, essa nova forma de dominação desestabiliza-se não somente pela possibilidade de uma revolução radical das sociedades modernas, mas principalmente porque há bem pouca calmaria no interior de sua própria racionalidade. Segundo Marcuse:

\begin{abstract}
Justamente na medida em que essa racionalidade formal não ultrapassa seu próprio nexo, tendo apenas seu próprio sistema como norma de cálculo e do agir calculadamente, ela é determinada "a partir do exterior", por algo outro que não ela mesma - assim, conforme a própria definição de Max Weber, a razão se porta "material”. Pois não há nenhuma relação que não seja posta e, enquanto posta, seja dependente; no continuum da história em que se desenvolve todo o agir econômico, toda razão econômica sempre é a razão da dominação, que determina o agir econômico como histórico-social. O capitalismo "científico" mais matematizado permanece como dominação matematizada, tecnologizada sobre pessoas, e o socialismo mais científico, tecnológico é construção ou derrubada de dominação. ${ }^{393}$
\end{abstract}

Posto isso, em “O Estado nacional e a política econômica”, Weber defronta-se com o peso e com a brutalidade da luta econômica pela existência. Nesse âmbito, não há alternativa possível. A história humana não existe para confirmar uma concepção abstrata e moralmente valiosa de justiça social nem para garantir a vitória dos mais bem desenvolvidos econômica ou culturalmente. A lição que se aprende nos confins da Alemanha é válida para o resto da nação e, em certa medida, para o conjunto das sociedades modernas. Se foram as mesquinhas constituições físicas e espirituais dos poloneses que permitiram o seu avanço territorial sobre a Alemanha é porque o processo de seleção em voga não reconhece o mérito dos oponentes nesse tipo de disputa.

O deslocamento dos assalariados alemães e sua substituição pela mão de obra dos povos eslavos é o resultado da agressiva concorrência entre essas duas nacionalidades pelos postos de 392 Idem. A ideologia da sociedade industrial; p. 25-26.

393 Idem. “Industrialização e capitalismo na obra de Max Weber”; p. 124. 
trabalho no solo. A maior capacidade adaptativa dos poloneses às condições econômicas adversas um trabalhador que pauta suas reivindicações pelo estômago ${ }^{394}$ - requer do estado alemão uma atitude peremptória: o fechamento da fronteira oriental e a compra sistemática de terras a fim de garantir a colonização por agricultores alemães ${ }^{395}$. Somente dessa maneira a germanidade do leste pode ser preservada contra todas as ameaças advindas com o fluxo eslavo e, finalmente, a economia nacional alemã se tornaria apta a garantir às próximas gerações as características pelas quais se atribui a grandeza humana e a nobreza de sua natureza ${ }^{396}$, isto é, a manutenção e o aperfeiçoamento do modo de ser da nação alemã. Segundo Weber:

\begin{abstract}
A luta econômica entre as nacionalidades também segue o seu curso sob a aparência de "paz", como vimos. Não é no combate aberto que os camponeses e diaristas alemães do leste foram desalojados por adversários politicamente superiores: é na silenciosa e enfadonha luta da vida econômica cotidiana que eles perdem em face de uma raça inferior, abandonam a pátria e vão submergir num futuro obscuro. Não há paz também na luta econômica pela existência; somente quem toma aquela aparência de paz pela verdade pode crer que o futuro reserve paz e felicidade para os nossos descendentes. Como sabemos, a política econômica nacional é concebida vulgarmente como uma especulação sobre receitas para oferecer felicidade ao mundo. Para quem pensa assim, a melhoria da "balança do prazer” da existência humana é a única meta compreensível do nosso trabalho. Basta, no entanto, a negra seriedade do problema populacional para impedir-nos de ser eudemonistas, de presumir a paz e a felicidade humana escondidas no seio do futuro e de acreditar que haja outra forma de abrir seu espaço na existência terrena senão a da dura luta do homem com o homem. ${ }^{397}$
\end{abstract}

Antes e acima de tudo, o que se impõe a quem dirige o estado nacional moderno é a salvaguarda de sua integridade. Blindados contra as otimistas fantasias a respeito do funcionamento da economia - a advertência é a mesma encontrada no portal do inferno de Dante: "lasciate ogni speranza” -, a tarefa dos responsáveis pela ordem política não é legar aos cidadãos uma parva concepção acerca das condições de felicidade e de bem-estar social ou de uma distribuição equânime dos bens materiais e culturais.

Ante as posturas necessariamente conflitantes da ordem política mundial, das disputas internas entre os estratos dominantes alemães animados por interesses socioeconômicos distintos e da ameaça de sublevação das massas populares, a esfera do poder deve alargar o seu campo de ação

394 Weber, Max. "O estado nacional e a política econômica”; p. 64.

395 Ibidem; p. 66.

396 Ibidem; p. 68.

397 Ibidem; p. 67. 
para fazer valer os seus interesses mais fundamentais e duradouros dentro e além dos limites territoriais. Tendo em vista a impossibilidade dos homens se despirem completamente de sua própria pele ${ }^{398}$, os processos de desenvolvimento econômico devem ser regidos a partir do imperativo de antepor os interesses permanentes do poder nacional acima de considerações de quaisquer outros tipos. Segundo Weber:

São interesses de poder nacional sempre que postos em questão, e são os interesses últimos e decisivos que a política econômica nacional de uma nação deve servir. A ciência da política econômica nacional é uma ciência política. Ela é uma serva da política, não da política momentânea dos grupos e classes dominantes no momento, mas dos perenes interesses de poder nacional. E o Estado nacional não representa para nós algo indefinido, que se imagina estar elevando tanto mais alto quanto mais a sua essência fica recoberta por névoas místicas, mas a organização mundana do poder nacional. E nesse Estado nacional o critério de valor definitivo que vale também para o ponto de vista da política econômica é para nós a "razão de Estado". Ela não significa para nós, ao contrário de um estranho mal-entendido, a "ajuda do Estado" no lugar da "ajuda própria”, a regulamentação estatal da vida econômica no lugar do livre jogo das forças econômicas. O que queremos exprimir, ao falarmos de razão de Estado, é a reivindicação de que o interesse de poder econômico e político da nossa nação e do seu portador, o Estado nacional alemão, seja a instância final e decisiva para as questões da política econômica alemã. ${ }^{399}$

Todavia, o diagnóstico weberiano é atento à dissociação entre os detentores do poder econômico na Alemanha na virada do século XIX e a sua vocação para a direção e para a condução da política ${ }^{400}$. A rispidez do seu discurso floresce da certeza de não encontrar interlocutores nem entre seus pares, nem nas demais camadas sociais. Tanto no estamento dos Junker quanto na burguesia alemã e até mesmo entre a classe dos trabalhadores não há indícios de que alguém reuniria as aptidões políticas necessárias a fim de deter o deslocamento territorial eslavo. De modo homólogo, ninguém parece se responsabilizar pelo desenvolvimento econômico e principalmente em assumir a missão perante a história de conformá-lo - bem como os demais fenômenos e forças sociais - aos interesses de longo prazo da pátria alemã.

Por sua transformação lenta e irresistível, a estrutura socioeconômica posterior à unificação do estado prussiano adiciona um componente bastante específico - o que o povo reivindica não é mais congruente com o que oferece um poder cesarista ${ }^{401}$. Às voltas com os problemas decorrentes

398 Ibidem; p. 68.

399 Ibidem; p. 69.

400 Ibidem; p. 72.

401 Ibidem; p. 74. 
de sua decadência social, a camadas dos Junker não pode responder aos requisitos de uma política de potência que a Alemanha precisa desempenhar. Perante a unidade nacional forjada sem a sua participação ativa, a burguesia acomodou-se a um papel secundário e alimenta inconvenientes veleidades de caráter apolítico e a-histórico. Lamentavelmente, ela celebraria o falso final da história e oscilaria entre embriagar-se com as conquistas do passado ou buscar avidamente a paz para o futuro ${ }^{402}$. Por fim, também as massas populares e a classe dos trabalhadores, mesmo quando não assediadas pelas inconvenientes concepções internacionalistas do socialismo moderno, ainda não atingiram o grau mínimo de maturação política para assumir os principais postos de mando no estado alemão - embora do ponto de vista econômico eles estivessem bastante bem informados a respeito de suas condições de sobrevivência e, legitimamente, reivindicassem a liberdade de representar seus interesses. Segundo Weber:

Em todas as épocas, atingir o poder econômico foi o que permitiu a uma classe conceber-se como candidata ao poder político. É perigoso e incompatível a longo prazo com o interesse nacional que uma classe economicamente decadente mantenha em mãos a dominação política. Mais perigoso ainda, contudo, é quando classes para as quais se movimenta o poder econômico, e com isso a candidatura para a dominação política, ainda não estejam politicamente maduras para a condução do Estado. Ambos esses perigos ameaçam atualmente a Alemanha e nisso resido de fato a chave para os presentes perigos da nossa situação. E também as mudanças na estrutura social do leste alemão, às quais se referem os fenômenos discutidos acima, pertencem a esse contexto maior. ${ }^{403}$

Além de antecipar os limites da tendenciosa concepção de ciência axiologicamente neutra, o ensaio inaugural de Weber teria como mérito desvelar a instabilidade imanente ao arranjo político das estruturas de dominação burocrática para Marcuse. A propalada fragilidade e imaturidade dos detentores do poderio econômico na Alemanha não são distintas das inerentes ao poder político durante o capitalismo moderno. Aquilo que Weber interpretava como uma languidez momentânea das classes e dos estamentos sociais alemães - principalmente no que diz respeito à burguesia - é intrínseco ao modo de organização e de funcionamento da administração política burocrática. As tentações de recorrer a figuras personalistas de comando, de subverter a legalidade dos processos de escolha dos representantes eleitos ou de lançar mão de estratégias de manipulação publicitária das 
massas são utilizados para se contornar debilidades originadas nos pressupostos materiais das sociedades modernas e que se aspergem coercitivamente pela vida política e social.

Se para Weber o indecoroso clamor de sua classe pelo surgimento de um novo regime cesarista, que a preserve tanto das ameaças das camadas populares quanto das extravagâncias sociais e políticas das antigas dinastias alemãs, deve-se por sua jovialidade e pela ausência de educação política ${ }^{404}$, o frankfurtiano interpreta a causa dessa opção de maneira distinta. É a caducidade da burguesia e das sociedades modernas que direciona o poder político nesse caminho incerto e obscuro. Segundo Marcuse:

Uma política de poder imperial exige industrialização intensiva e extensiva - e vice-versa. A economia precisa servir à razão de Estado do Estado político nacional, trabalhando com os seus meios. A colonização e a força militar são meios dessa ordem meios para a realização dos objetivos e dos valores extracientíficos aos quais a economia axiologicamente neutra precisa se subordinar. Como razão histórica, a razão de Estado exige a dominação daquela classe que pode executar a industrialização e por essa via realizar a acessão da nação - a dominação da burguesia. É perigoso quando (como os Junker na Alemanha) uma "classe economicamente decadente detém em suas mãos a dominação”. Assim, pressionada por valores políticos, extracientíficos, a ciência econômica se torna em Max Weber na crítica político-sociológica do Estado fundado por Bismarck. E essa crítica antecipa de maneira inaudita o futuro; a classe com vocação histórica, a burguesia, é "imatura" na Alemanha. Em sua debilidade anseia por um novo César que a dispense de agir ${ }^{405}$.

Nesse sentido, o vespeiro não está na suposta imaturidade social e política da burguesia alemã contemporânea a Weber - sua força motriz pulsa mesmo do coração da ratio. É a própria razão ocidental, atuando segundo seus preceitos mais estritos, que conduziria a política moderna a esse tipo de irracionalidade. Mais uma vez, a ratio mostra-se inerte ante os valores sociais que a compuseram. O poder político nacional transforma-se em imperialismo no momento em que o capitalismo moderno aguça a luta competitiva entre forças e poderes sociais desiguais ${ }^{406}$, tanto no plano interno como na concorrência entre os países.

Ao retirar da razão toda perspectiva de avaliação crítica sobre as formas de organização da sociedade radicaliza-se o abismo entre as reais exigências da administração política e as demandas oriundas de processos econômicos desenfreados. A formalidade dos procedimentos de dominação

404 Ibidem; p. 76.

405 Marcuse, Herbert. “Industrialização e capitalismo na obra de Max Weber”; p. 120.

406 Ibidem; p. 131. 
burocrática já não consegue mais cumprir sua missão e escancara-se a ausência de continuidade entre as esferas da economia e da política. A técnica que nunca foi neutra perde seus constrangimentos e abraça definitivamente o conteúdo de dominação política da sociedade que lhe forjou.

De acordo com Marcuse, a sociologia weberiana conseguiu tematizar a respeito dessa encruzilhada. Embora com certa hesitação em aplicar o conceito de carisma à sociedade industrial $^{407}$, Weber não deixou de perceber essa dissociação entre a racionalidade econômica do capitalismo e a forma eminentemente moderna de domínio social. A difusa dinâmica à qual está submetida a dominação carismática corporificaria as regressões e os desvarios do tumultuoso movimento da esfera política no capitalismo moderno. Segundo Marcuse:

Assim o capitalismo com toda sua racionalidade (ou justamente por causa da sua racionalidade específica) culmina em uma ponta irracional, “acidental” - não somente na economia, mas também no domínio sobre a própria administração burocrática, na administração do Estado. (Aqui é difícil não pensar na Filosofia do Direito de Hegel, em que o Estado da sociedade civil, o Estado da Razão, culmina na pessoa “acidental” do monarca determinado pela contingência do nascimento; tanto em Hegel como em Weber a análise da burguesia explicita a sua razão: ela nega a si mesma em sua realização plena. $)^{408}$

Voltando a Weber, o capítulo “A dominação carismática e sua transformação” de ES destaca, inicialmente, a instabilidade, a volubilidade e o aspecto excepcional da forma de dominação instaurada por lideranças carismáticas. Diferentemente das estruturas burocráticas ou patriarcais, formações de caráter cotidiano e que respondem pela satisfação de necessidades ordinárias e constantes, a dominação carismática suscita e se origina a partir de experiências incomuns e extracotidianas - em uma palavra, nasce do desespero ou do entusiasmo ${ }^{409}$.

Subvertendo valores consolidados ou desrespeitando toda sorte de normas e regulamentações, não se é permitido nem mesmo interpretar a ascensão de suas lideranças como uma espécie de eleição racional ou de submissão consciente por parte de seus seguidores. Na verdade, há um duplo mecanismo de reconhecimento que repele qualquer aproximação guiada por critérios racionais ou por saberes baseados em parâmetros tradicionais. O líder sabe-se possuidor de 
um carisma especial, de um dom particular e, na maior parte das vezes, natural. Dotado dessa capacidade individual extraordinária, ele reúne em torno de si as expectativas de uma nova era.

Ao mesmo tempo, o seu séquito enxerga em sua figura a possibilidade do irradiar de novos valores e de uma nova sociedade. A partir de então, inaugura-se um exacerbado momento de revolucionamento social ${ }^{410}$. Todos os preceitos válidos anteriormente, o conjunto de saberes e de instrumentos técnicos utilizados, as convenções morais mais arraigadas e mesmo as duradouras e naturalizadas formas de sociabilidade sofrem um descrédito radical. De ouvidos moucos a quaisquer reivindicações originadas de atividades formalmente racionalizadas, eles fazem valer tudo o que se coloca fora dos vínculos desse mundo, o que está além das obrigações requeridas pelas profissões comuns e dos deveres familiares cotidianos ${ }^{411}$. Segundo Weber:

Enquanto a ordem burocrática se limita a substituir a crença na santidade daquilo que existe desde sempre, nas normas da tradição, pela sujeição a regras estatuídas para determinado fim e pelo saber de que estas, desde que se tenha poder para isto, podem ser trocadas por outras regras com determinado fim, não sendo, portanto, nenhuma coisa "sagrada", o carisma, em suas formas de manifestação mais supremas, rompe todas as regras e toda a tradição e mesmo inverte todos os conceitos de santidade. Em vez da piedade diante dos costumes antiquíssimos e por isso sagrados, exige o carisma a sujeição íntima ao nunca visto, absolutamente singular, e portanto divino. Neste sentido puramente empírico e não-valorativo, é o carisma, de fato, o poder revolucionário especificamente “criador" da história. ${ }^{412}$

De uma parte, a dominação carismática tende paulatinamente a se objetivar. No entremeio de uma vida emocional alheia à cotidianidade das preocupações econômicas e uma lenta morte por asfixia acarretada pelo peso dos interesses materiais ${ }^{413}$, sua disposição imediatamente mais

410 É importante ressaltar que, embora a racionalização burocrática possa acarretar uma mudança revolucionária no interior de uma comunidade ou sociedade de base tradicional, o conjunto de transformações desencadeadas pela liderança carismática é de outra espécie. Em certo sentido, enquanto a primeira age sobretudo na organização econômica e social da sociedade, a segunda influi inicialmente sobre os próprios sujeitos. Segundo Weber: “Conforme vimos, também a racionalização burocrática pode ser e tem sido muitas vezes um poder revolucionário de primeira ordem diante da tradição. Mas esta revoluciona, por meios técnicos e em princípio 'de fora para dentro’ - como o faz precisamente toda transformação no campo econômico -, primeiro as coisas e as ordens, e depois, a partir dali, os homens, e estes últimos, no sentido de uma modificação de suas condições de adaptação e eventualmente de um aumento de suas possibilidades de adaptação ao mundo circundante, mediante o estabelecimento de fins e meios racionais. O poder do carisma, ao contrário, fundamenta-se na fé em revelações de heróis, na convicção emocional da importância e do valor de uma manifestação de natureza religiosa, ética, artística, científica, política ou de outra qualquer, no heroísmo da ascese, da guerra da sabedoria judicial, do dom mágico ou de outro tipo. Esta fé revoluciona os homens 'de dentro para fora' e procura transformar as coisas e as ordens segundo seu querer revolucionário.” Ibidem; p. 327.

411 Ibidem; p. 325.

412 Ibidem; p. 328.

413 Ibidem; p. 331. 
distinguível é fazer a população se enfastiar com a ebulição revolucionária. A escolha dos sucessores do líder primevo, a consolidação de alguns procedimentos para reconhecer as reencarnações subsequentes do carisma, a institucionalização de uma camada de sacerdotes que se arrogam possuir a interpretação fiel de uma dada profecia entre tantos outros fenômenos impelem as sociedades humanas a tipos distintos - e mais estáveis - de arranjo político. Tanto por pressões imanentes a essa forma de dominação quanto por demandas oriundas de outros momentos da vida social, há sempre uma ameaça dos senhores carismáticos perderem subitamente tudo aquilo que os particularizava entre os demais membros da comunidade.

A profecia converte-se em dogma ou em doutrina, o príncipe guerreiro aposenta suas armas e encastela-se junto aos seus comensais e, nessa penetração do carisma na vida cotidiana das sociedades, ocorre uma profunda transformação em seu caráter e em seu modo de atuação. O círculo mágico que outrora consagrava a excitação comum a esse grupo de pessoas se corrompe e, como um passo quase inevitável, os interesses dos detentores de poder econômico e social deslegitimam a autoridade fundamentada no sagrado a fim de garantir as suas posses ${ }^{414}$.

O caminho foi longo e comportou muitos vacilos. Todavia, abriu-se espaço para a transmutação e o fortalecimento de formas de dominação baseadas em outros critérios. A dominação carismática ou institucionaliza-se amparada em vínculos tradicionais ou se estrutura em torno de normas e regras racionais do ordenamento social. Segundo Weber:

Portanto, a dominação carismática “pura” é instável num sentido muito específico, e todas as suas alterações têm, em última instância, uma única fonte. Na maioria das vezes, o desejo do próprio senhor, mas sempre o de seus discípulos e mais ainda o dos adeptos carismaticamente dominados, é de transformar o carisma e a felicidade carismática de uma agraciação livre, única, externamente transitória de épocas e pessoas extraordinárias em uma propriedade permanente da vida cotidiana. Seja que do séquito carismático de um herói guerreiro nasça um Estado, ou que da comunidade carismática de um profeta, artista, filósofo ou inovador ético ou científico nasçam uma igreja, seita, academia, escola, ou então que de um grupo carismaticamente dirigido, que persegue uma ideia cultural, nasça um partido ou apenas um aparato de jornais e revistas - em todos estes casos a forma de existência do carisma acaba exposta às condições da vida cotidiana e aos poderes que a dominam, sobretudo aos interesses econômicos. ${ }^{415}$

Contudo, a dominação carismática também pode se vincular às contingências de uma 
transformação de um tipo distinto. Isso porque, nem toda forma de dominação moderna - seja ela democrática ou não - é alheia ao carisma. De acordo com Weber, embora permaneça sob constante fogo cerrado do poder cotidiano da empresa dos partidos, todo efeito emocional sobre a massa da população coage as instâncias burocráticas dos partidos modernos e das atividades eleitorais a servirem às lideranças carismáticas ${ }^{416}$. Talvez com alguma desconfiança e, certamente, com descontentamento mútuo, essas duas maneiras de conquistar e lidar com o poder político rivalizam entre si na organização interna dos partidos políticos e do próprio estado moderno. Além do estilo político contrastante, as éticas econômicas de cada um desses segmentos parecem inconciliáveis.

De um lado, a burocracia partidária fiscaliza impertinentemente os recursos financeiros dispendidos a fim de conter desperdícios e de racionalizar a contabilidade dos partidos. Por outro, os seus expoentes carismáticos menosprezam tais cuidados. Em momentos excepcionais nos quais os heróis carismáticos conseguem suplantar o mecanismo regular da organização partidária, eles invariavelmente buscam impor formas plebiscitárias de designação de cargos e, eventualmente, conseguem até mesmo transformar a própria estrutura da maquinaria de nomeação dos cargos ${ }^{417}$.

No mais das vezes, há uma luta encarniçada entre aqueles que se julgam como portadores de carismas especiais e os que apostam no uso racional dos montantes financeiros, no planejamento estratégico da distribuição dos cargos e no enquadramento contábil do conteúdo dos panfletos políticos. Segundo Weber:

No lugar da oscilação entre a obediência carismática, por um lado, e a obediência aos honoratiores, por outro, aparece então a luta entre o empreendimento burocrático e a chefia carismática do partido. Quanto mais desenvolvida a burocratização e quanto mais extensos os interesses diretos e indiretos em prebendas e oportunidades ligados ao empreendimento do partido, tanto maior a probabilidade deste cair nas mãos de “especialistas” nessa área - quer estes apareçam como empresários livres, como os bosses na América - encontrando-se nas mãos destes as relações pessoais sistematicamente estabelecidas com os homens de confiança, os agitadores, inspetores e o resto do pessoal indispensável, as listas e documentações e todo o outro material, cujo conhecimento possibilita a direção da maquinaria do partido. Uma influência eficaz sobre a atitude do partido e eventualmente uma separação bem-sucedida deste último somente podem realizar-se por meio da posse de tal aparato. ${ }^{418}$

416 Ibidem; p. 339.

417 Ibidem; p. 341.

418 Ibidem; p. 340. 
No entanto, além dessa desassossegada concorrência, é possível perceber também uma espécie de complementariedade entre essas duas tendências. Embora assumam as feições de um diálogo conflituoso, as relações entre a dominação burocrática e a carismática não se esgotam em acusações de pragmatismo eleitoral ou de irresponsabilidade administrativa. De acordo com Weber, cada uma dessas formas parece requerer de si mais do que a simples reprodução de seus próprios fundamentos - e isso não somente por conta da fluidez inerente à sua natureza de tipo ideal.

$\mathrm{Na}$ verdade, elas entrelaçam-se continuamente. As estritas definições que as delimitam rigidamente escorrem-se uma na outra, e as suas formas parecem encontrar algum tipo de complementariedade na empiria. Pois ainda que a dominação racional se construa sobre fundamentos sólidos e duradouros, ela não se quer apenas permanente, mas também legítima. Seguidoras de uma teodiceia da felicidade, as camadas dominantes não se satisfazem em concentrar e exercer o poder de mando. Elas querem que sua posição de destaque seja merecida.

Se a institucionalização burocrática lhes garante uma vida longa e estável ao ampliar sua zona de ação, a sua racionalidade carateristicamente fria não suscita reverência suficiente entre os dominados ${ }^{419}$. Mesmo sob o risco constante de dissolução após um breve instante, a irracional adesão ao carisma de um demagogo moderno coroa a dominação social de um tipo de veneração inatingível às instituições burocráticas. Segundo Weber:

O rei parlamentar, apesar de sua falta de poder, é conservado, sobretudo porque, com sua mera existência e pelo fato de que o poder se exerce "em seu nome”, ele garante, em virtude de seu carisma, a legitimidade da presente ordem social e de propriedade, tendo todos os interessados nesta situação que temer, como consequência de sua destronização, o abalo da crença na "legitimidade" desta ordem. Ao lado da função da "legitimação" dos atos governamentais do partido vitorioso, tarefa que, do ponto de vista puramente formal, pode também ser realizada por um presidente eleito segundo regras estabelecidas, o monarca parlamentar exerce uma função que não poderia cumprir o presidente eleito: põe um limite formal às pretensões de poder dos políticos, pelo fato de estar ocupada, de uma vez por todas, a posição mais alta do Estado. ${ }^{420}$

419 É certo que para Weber a dominação racional ou burocrática também reúne critérios internos de legitimação. A esse respeito, em “Os três tipos puros de dominação legítima”: “Obedece-se não à pessoa em virtude de seu direito próprio, mas à regra estatuída, que estabelece ao mesmo tempo a quem e em que medida se deve obedecer. Também quem ordena obedece, ao emitir uma ordem, a uma regra: à 'lei' ou 'regulamento' de uma norma formalmente abstrata. O tipo daquele que ordena é o 'superior', cujo direito de mando está legitimado por uma regra estatuída, no âmbito de uma competência concreta, cuja delimitação e especialização se baseiam na utilidade objetiva e nas exigências profissionais estipuladas para a atividade profissional.” Idem. "Os três tipos puros de dominação legítima”; p. 129.

420 Idem. ES; p. 355. 
Diferentemente de Weber, Marcuse prefere ressaltar aquilo que se petrifica por meio desse esvaecimento. Caso seja legítimo imaginar uma transformação substancialmente racional da dominação burocrática, ela certamente não deve se contaminar pelo atávico magnetismo de um líder carismático. Quando isso ocorre, é sinal de que a vida política não corresponde ao estágio no qual as sociedades humanas poderiam estar, mas se acomoda às vicissitudes de um mundo social que dá as costas para os homens e para a razão.

Para tais sociedades, o que realmente importa são os negócios. Menos do que indicar um período de mudanças profundas e revolucionárias, onde haja uma verdadeira criação de novos valores e da emergência de modelos emancipados de sociabilidade, está-se diante de uma formação social que funciona a partir da profunda abstração de tudo o que seja humano ou histórico. A desumanidade e a negação da vida real são traços de normalidade da racionalidade corrente ${ }^{421}$.

Mantendo-se sob esses estreitos limites, a esfera política repisa o coetâneo agrilhoamento da vida social. A reiteração da sequência de acontecimentos que meramente repõe os fundamentos econômicos, sociais e culturais da modernidade capitalista tolhe a fantasia que deveria reger as formas de organização das sociedades. As questões e as indecisões concernentes à tomada do poder pela burguesia ascendente, que no caso alemão exigia a modernização do Estado ainda pré-burguês, reaparecem nas sociedades industriais avançadas. Incapaz tanto de evitá-la quanto de levá-la às últimas consequências, a democracia nessas sociedades torna-se sinônimo de uma ditadura plebiscitária $^{422}$.

Como um de sismógrafo dos tremores que a ratio enfrenta em seu cotidiano, a sociologia weberiana capta o duplo processo de desenvolvimento assumido pela dominação política com o desdobrar histórico das sociedades modernas. Em um tempo no qual as boas novas não passam da reiteração dos velhos valores e das antigas práticas sociais - quase um jogo de cartas marcadas - o carisma reverte-se em uma espécie de reafirmação de interesses privados previamente consolidados 
e na tentativa de organizá-los a fim de que sua existência se propague indefinidamente. Ao ser

simples instrumento incapaz de propor fins e objetivos materialmente racionais para si mesma, a administração burocrática desrespeita a expectativa de formalidade de seus procedimentos e sucumbe ante a irracionalidade dos valores legados pela burguesia. O seu destino é assumir a sua dependência dos feitios e das particularidades de um líder carismático. Segundo Marcuse:

Entretanto essa administração racional de massas e coisas não pode dispensar o ápice carismático irracional. Pois a administração, justamente na medida em que é efetivamente racional, tenderia à superação da dominação (administração de coisas); mas o aparelho administrativo sempre foi edificado no plano da dominação, sendo instituído com o objetivo de conservação e fortalecimento desta. Assim, à democratização exigida pela administração racional corresponde uma paralela limitação e manipulação da democratização. A dominação como privilégio de interesses particulares, por um lado, e autodeterminação como expressão de interesses gerais, por outro, precisam assim ser forçados à reunião. Essa solução forçada e simultaneamente formal-racional, isto é, tecnicamente eficiente, da contradição tem sua manifestação clássica na democracia plebiscitária, em que as massas periodicamente depõem seus líderes e lhes determinam a política - em condições preestabelecidas e bem controladas pelos líderes. ${ }^{423}$

\section{Ascetismo intramundano e sacrifício.}

Se for certo que o ascetismo intramundano perdeu suas funções e suas justificativas

econômicas que gozava outrora ${ }^{424}$, nem por isso as exigências de severidade e de austeridade no trato com seus desejos abandonaram os homens modernos. Transfigurado no curso das sociedades capitalistas, a repressão da satisfação das pulsões individuais inaugura um período de exacerbada agressividade. Essa civilização que se coaduna com a dominação concebe a sua reprodução de um

423 Ibidem; p. 127-128.

424 Convém ressaltar que, mesmo para Weber, as consequências econômicas não figuram entre as principais causas do ascetismo intramundano. Como se sabe, Weber volta-se para o componente eminentemente religioso e relativo à salvação e à cura das almas presente nas discussões teológicas da reforma protestante. Segundo Weber: "Se portanto, para a análise das relações entre a ética do antigo protestantismo e o desenvolvimento do espírito do capitalismo partimos das criações de Calvino, do calvinismo e das demais seitas 'puritanas', isso entretanto não deve ser compreendido como se esperássemos que algum dos fundadores ou representantes dessas comunidades religiosas tivesse como objetivo de seu trabalho na vida, seja em que sentido for, o despertar daquilo que aqui chamamos de 'espírito capitalista'. Impossível acreditar que a ambição por bens terrenos, pensada como um fim em si, possa ter tido para algum deles um valor ético. (...). A salvação da alma, e somente ela, foi o eixo de sua vida e ação. Seus objetivos éticos e os efeitos práticos de sua doutrina estavam ancorados aqui e eram, tão-só, consequências de motivos puramente religiosos. Por isso temos que admitir que os efeitos culturais da Reforma foram em boa parte - talvez até principalmente, para nossos específicos pontos de vista - consequências imprevistas e mesmo indesejadas do trabalho dos reformadores, o mais das vezes bem longe, ou mesmo ao contrário, de tudo o que eles próprios tinham em mente.” Weber, Max. A ética protestante e o “espírito” do capitalismo; p. 81. Na verdade, o fenômeno que Marcuse procura compreender é o novo sentido assumido pelo tema do ascetismo intramundano. Diante uma sociedade na qual o consumo de mercadorias supérfluas se torna cada vez mais importante para a sua reprodução, a perpetuação de um comportamento ascético acarreta outras consequências e, por isso, necessita ser interpretado em novos termos. 
modo bastante curioso. As mesmas forças que impelem o seu desenvolvimento são as causas que colocam em xeque a sua própria existência. De certo que isso já não mais ocorre como era nos primórdios do capitalismo moderno, quando a burguesia forjou as armas e os homens que seriam responsáveis por sua superação - a revolução política e o proletariado ${ }^{425}$. Ante a união entre a aceleração da produtividade e a destruição crescente, sustentada pelo exasperante conluio entre os negócios e o trabalho ${ }^{426}$, a liberdade e a independência de pensamento se circunscreveram a uma imprensa livre que se autocensura; a política, a uma democracia que restringe a escolha a partidos equivalentes; a economia, a uma força mais irresistível e inquestionável; e o mundo, a uma monotonia infernal.

Potencialmente apta a construir uma ordem social não marcada pela opressão econômica, os homens modernos parecem se esquecer da felicidade e buscam a mais célere adaptação a uma vida mortificada. Apesar dos perigos iminentes de uma catástrofe nuclear, o que verdadeiramente apavora nas sociedades industriais avançadas é a sua própria imanência. Principal responsável por inúmeras ameaças, a civilização que se formou no Ocidente malversa não apenas sua base material e sua capacidade tecnológica em favor da preservação da exploração capitalista do trabalho humano. As produções intelectuais e culturais e a própria formação subjetiva dos indivíduos são atreladas à engrenagem de dominação socioeconômica. Segundo Marcuse:

Certamente também o capitalismo desenvolvido é construído sobre o "sacrifício": a luta pela existência e a exploração da força de trabalho precisam continuar de modo sempre mais intenso se a acumulação ampliada deve permanecer possível; aqui a planned obsolescense (obsolescência planejada), a contrarrazão metódica se torna necessidade social. Esse já não é o modo da burguesia como classe que desenvolve as forças produtivas - é muito mais o estigma da destruição produtiva nos termos da administração total. E o cálculo capitalista da rentabilidade e da eficiência matematizadas festeja seus maiores triunfos no cálculo assumido do ocaso, do risco da destruição de si próprio frente à destruição do inimigo. ${ }^{427}$

A interpretação do papel do ascetismo intramundano é crucial para essa questão. Por um lado, permite-se perscrutar as disposições subjetivas que compõem a imprescindível contrapartida às estruturas sociais das sociedades modernas. Seja por meio das ferramentas conceituais para a

425 Marx, K. e Engels, F. "Manifesto do partido comunista”; p. 14.

426 Marcuse, Herbert. A ideologia da sociedade industrial; p. 16.

427 Idem. "Industrialização e capitalismo na obra de Max Weber”; p. 118. 
compreensão da racionalidade da ação social dos agentes individuais em determinada configuração sócio-histórica, seja a fim de rastrear a base psíquica que possibilita aos homens se adequarem às instâncias de poder burocráticas e ao status quo, elas são tanto o resultado como o pressuposto do funcionamento e da reprodução dessa sociedade. O que foi dito a respeito da configuração da razão ocidental, do modo de funcionamento e de legitimação da política moderna e até mesmo da forma de organização da produção material de mercadorias é dependente dessa pré-moldagem subjetiva ${ }^{428}$.

Figura de destaque entre os elementos de sua conceitualização acerca do capitalismo moderno, o ascetismo intramundano está entre as principais características da religiosidade peculiar às várias seitas e denominações protestantes analisadas por Weber. Se Martinho Lutero dotou de significado religioso a noção de vocação profissional, apenas com Calvino o ideal de vida ascético tornou-se o modelo de conduta intramundana individual glorificado teologicamente. De acordo com Weber, o sentimento religioso de redenção sempre fora acompanhado na história do cristianismo pela compreensão de que o estado de graça dependeria, antes de tudo, de uma potência objetiva e não do valor pessoal dos fieis. A doutrina da predestinação e a concepção a respeito do particularismo da graça radicalizaram e coloriram com uma inaudita coerência lógica essa ideia. A distância que se abre entre o santo e o não-santo, finalmente, mostrou-se inescrutável ao saber humano ${ }^{429}$. Paralelamente, a dissociação entre a ação humana e os meios de influenciar os desígnios divinos permanece igualmente incontornável. O homem - morto pelo pecado - é visto como incapaz de converter a sua ação e a sua vontade em vista de um bem espiritual que o leve à salvação ${ }^{430}$.

Todavia, ainda que a sua observância fosse inócua para alterar o destino traçado por Deus e

428 A esse respeito, segundo Kellner: “É importante notar que para Marcuse, a reconstrução da subjetividade, a criação de uma racionalidade erotizada, e o desenvolvimento do ser criativo livre só consegue ter lugar por meio de uma transformação prática das relações e atividades sociais. Marcuse argumenta que a sociedade existente é organizada precisamente para prevenir a reconstrução da subjetividade e de novas relações sociais, ao fornecer em vez disso um regime de dominação, autoridade, repressão, dessublimação repressiva e submissão. (...), Marcuse apresenta uma crítica às formas de dominação e de subjetividade hegemônicas e uma alternativa para superar a subjetividade unidimensional, conformista e normativa das sociedades tecnológicas avançadas.” Kellner, Douglas. "Marcuse and radical subjectivity"; p. 89.

429 Weber, Max. A ética protestante e o “espírito” do capitalismo; p. 219.

430 Ibidem; p. 91. 
redimir os réprobos, a rigorosa disciplina calvinista fortalece o sentimento de comprovação da graça entre os eleitos. Embora esses preceitos não garantissem salvação a ninguém, o ascetismo intramundano pode ser encarado como uma espécie de falso substituto dos sacramentos no puritanismo. Em primeiro lugar, falso pela ojeriza dos puritanos a elementos mágicos incrustados em suas condutas religiosas - toda atividade que ensaiasse certa proximidade à concretude de rituais mágicos ofendia a sensibilidade protestante de maneira repugnante ${ }^{431}$. Além disso, falso também pela radical diferença na mais imediata consequência prática para a vida dos seus fieis. Não há mais descanso possível e o simples acúmulo progressivo de obras meritórias isoladas não apenas é incapaz de amainar a incerteza de estar entre os eleitos como é prova definitiva da insuficiência da fé, da rendição diante do pecado e, portanto, da condenação inapelável. Segundo Weber:

\begin{abstract}
De uma coisa apenas sabemos: que uma parte dos seres humanos está salva, a outra ficará condenada. Supor que mérito humano ou culpa humana contribuam para fixar esse destino significaria encarar as decisões absolutamente livres de Deus, firmadas desde a eternidade, como passíveis de alteração por obra humana: ideia impossível. Do "Pai que está no céu”, mostrado pelo Novo Testamento de forma acessível à compreensão humana, o qual se alegra com o regresso do pecador feito a mulher que acha a moeda que havia perdido, deu lugar aqui a um Ser transcendente que escapa a toda compreensão humana e que, desde a eternidade, por decretos de todo insondáveis, fixa o destino de cada indivíduo e dispõe cada detalhe no cosmos. Uma vez estabelecido que seus decretos são imutáveis, a graça de Deus é tão imperdível por aqueles a quem foi concedida como inacessível àqueles a quem foi recusada. ${ }^{432}$
\end{abstract}

Porém, o fatalismo que se poderia esperar a partir da dedução puramente lógica de tais preceitos recebeu algum alento com essa ideia de comprovação ${ }^{433}$. É certo que a tensão psicológica

431 A esse respeito, é essencial salientar a fecundidade da noção weberiana de “desencantamento do mundo” para se compreender a radicalidade das transformações operadas pelo protestantismo e seu amplo alcance para a interpretação de Weber das sociedades modernas. Conceito esse que, como Flávio Pierucci destaca de modo rigoroso e pormenorizado, particulariza o tipo específico de racionalização atuante no Ocidente e, mais propriamente, o processo de longa duração que se inicia com os profetas do judaísmo antigo e culmina com as seitas protestantes. Segundo Pierucci: "Noutras palavras, o termo desencantamento entendido como desmagificação assume a dimensão de um 'grande' processo histórico que é especificamente ético-religioso e especificamente ocidental, e assim pretende designar, quase à guisa de um nome próprio e não comum, o longuíssimo período de peculiar racionalização religiosa por que passou, mercê de motivos puramente históricos [rein historisch], a religiosidade ocidental sob a hegemonia cultural alcançada por esta forma 'caracteristicamente moralizada' de fé monoteísta repressora da magia universal chamado judeu-cristianismo. Seus criadores e primeiros portadores [Träger] foram os profetas de Israel, florão do judaísmo antigo; e foram as seitas protestantes seus radicais e autoconfiantes portadores [Träger] na época heroica do parto cultural da moderna civilização do trabalho, seu ponto de chegada religioso. Daí para a frente, a ciência empírica moderna, esse ‘ímpio fado’ de 'nosso tempo’, irá se encarregar de determinar-lhe novos desdobramentos mas também novas direções ao reduzir o mundo, já desmagificado sob o modo da moralização religiosa, a um mero mecanismo causal sem totalidade possível e sem mais nenhum sentido objetivo.” Pierucci, Antônio Flávio. O desencantamento do mundo; p. 199-200.

432 Weber, Max. A ética protestante e o “espírito” do capitalismo; p. 94-95.

433 Ibidem; p. 217-218. 
a respeito da salvação permaneceu latejando brutalmente entre os puritanos. No entanto, a vida

purificada e a bravia resistência contra toda sorte de tentações atuou como um elemento determinante na sistematização e na metodização da conduta individual. Um penoso trabalho físico e psíquico, realizado de maneira cotidiana e rigorosa, é o principal instrumento contra a sedução dos pecados que, por ventura, continuem ameaçando os fieis. Desse modo, a irracionalidade de qualquer vivência religiosa fora filtrada através de uma malha espessa ${ }^{434}$.

Concebido de acordo com os rigores de um sistema teórico, o ascetismo intramundano submete-se aos imperativos da coerência lógica. A lei divina já não é mais vista apenas como uma norma inatingível para a qual, na medida do possível, os homens deveriam se dirigir. Na verdade, trata-se de um ideal santificado por meio do qual os homens obrigaram-se a conviver sob uma disciplina opressiva. Como se sabe, essa fria racionalização do agir no mundo espalha-se por todas as atividades cotidianas, nos modos de se lidar com desejos e nas relações interpessoais e familiares. Em A ética protestante:

\begin{abstract}
A práxis ética do comum dos mortais foi assim despida de sua falta de plano de conjunto e sistematicidade e convertida num método coerente de condução da vida como um todo. Não foi por acaso que o rótulo 'metodistas' colou naqueles que forma os portadores do último grande redespertar de ideias puritanas do século XVIII, da mesma forma que aos seus antepassados espirituais do século XVII fora aplicada, com plena equivalência de sentido, a designação de "precisistas”. Pois só com uma transformação radical do sentido de toda a vida, a cada hora e a cada ação, o efeito da graça podia se comprovar como um arranque do status naturae rumo ao status gratiae. A vida do "santo" estava exclusivamente voltada para um fim transcendente, a bem-aventurança, mas justamente por isso ela era racionalizada [de ponta a ponta] em seu percurso intramundano e dominada por um ponto de vista exclusivo: aumentar a glória de Deus na terra - jamais se
\end{abstract}

434 Convém adiantar um trecho no qual Marcuse se contrapõe diretamente à interpretação weberiana do protestantismo. O “equívoco" de Weber é que ele não consegue se aperceber que a racionalização protestante não elimina a irracionalidade da própria sociedade. Segundo Marcuse: "Em contraposição à ênfase frequentemente exagerada quanto ao caráter racional e 'calculista' do ‘espírito' protestante-capitalista, é preciso salientar seus elementos irracionais. Sobre a base dessa forma de existência 'ideal-tipicamente’ racionalizada e calculada até os mínimos detalhes, à base desse 'estabelecimento’ global que envolver a vida particular, a família, a empresa, existe uma desordem derradeira: o cálculo não deixa resto. A tortura diária do ‘ascetismo do mundo interior' pelo sucesso e lucro tem que sentir o lucro e o sucesso, caso realmente ocorram, como felicidade inteiramente imprevisível e se vê sempre de novo diante do medo da perda: a reprodução de toda a sociedade só é possível em meio a uma crise permanente. O fato de que a produção e a reprodução da vida não possam ser controladas racionalmente por esta sociedade se manifesta sempre na consciência teológica e filosófica. O terrível Deus absconditus do calvinismo é apenas uma das formas extremas dessa manifestação. (...). A 'razão', sob cujo signo a burguesia travou seus combates mais gloriosos, exatamente nessa sociedade foi privada de sua realização. O setor da natureza controlado pelo homem por meio de métodos racionais é, em comparação com a Idade Média, infinitamente maior, o processo de produção material da sociedade foi racionalizado até os mínimos detalhes em amplas esferas, mas, como tudo isso, permanece 'irracional' com um todo. Esses antagonismos aparecem na duplicidade das relações de autoridade burguesas sob as mais diversas formas: ela são racionais e, apesar disso, acidentais; objetivas, mas anárquicas; necessárias, mas ruins.” Marcuse, Herbert. “Estudo sobre a autoridade e a família”; p. 59-60. 
levou tão a sério a sentença omnia in majorem Dei gloriam. E só uma vida regida pela reflexão constante podia ser considerada superação do status naturalis: foi com essa reinterpretação ética que os puritanos contemporâneos de Descartes adotaram o cogito ergo sum. Essa racionalização conferiu à piedade reformada seu traço especificamente ascético e consolidou tanto seu parentesco íntimo quanto seu antagonismo específico com o catolicismo. ${ }^{435}$

Frio feito uma geada, o ascetismo intramundano despiu de naturalidade as concepções tradicionais sobre a vida e sobre a atividade humana. Correlata a uma vigília constante e pormenorizada, a própria essência do pecado sofre uma alteração sutil, porém plena de consequências. O mal e as tentações que assediam os homens não estão confinados paixões e nos sentimentos usualmente classificados como portadores de conteúdo pecaminoso. A rotina e o cálculo sem sobra voltam-se contra tudo o que não seja conforme o esquadro da razão divina, isto é, recobrem os afetos que se satisfazem de maneira desmedida e irracional ${ }^{436}$. Assim, a sexualidade experimentada de forma intensa e desregulada, a cobiça e a cupidez pela riqueza e pelos valores materiais, a busca irrefreada pelo desfrute de bens mundanos e de prazeres sensoriais entre outros elementos ofendem a deus por seus traços de divinização da criatura. Uma sóbria e bem temperada conduta de vida é a única alternativa para agir consoante o imperativo de multiplicação da glória do ser absoluto.

O afastamento monástico não faz surtir os mesmos efeitos. Retrospectivamente, a ideia luterana de que os homens deveriam se manter em determinadas profissões e desempenhá-las com o máximo de desvelo seria uma pálida precursora da transformação decisiva. Somente com Calvino, o trabalho profissional despiu-se de antigas travas e passou a ser concebido a partir da abundância de seus frutos. Obviamente, o elemento ético - isto é, desempenhá-lo como um dever moral, ou melhor, como um chamado religioso cuja renúncia se equipara a desobedecer a um mandamento de deus - persistia vivo e a futura rija crosta de aço ainda pesava como um simples leve manto sobre seus ombros ${ }^{437}$. Embora o seu objetivo não fosse o desfrute particular de suas benesses, a especialização das funções, a intensa mobilidade e a mudança de profissões e o trabalho

435 Weber, Max. A ética protestante e o “espírito” do capitalismo; p. 107.

436 Ibidem; p. 222.

437 Ibidem; p. 165. 
desempenhado por força de sua produção superior de riquezas figuravam entre os principais

elementos valorizados por esse ascetismo intramundano. Segundo Weber:

No profundo desdém com que os relatos dos interrogatórios dos mártires puritanos contrapõem ao barulhento falatório dos nobres prelados e funcionários a reserva serena e calma de seus fiéis, já se nota aquele apreço pelo autocontrole reservado que ainda hoje caracteriza os melhores tipos do gentleman inglês e anglo-americano mesmo dos dias de hoje. Falando em jargão corrente: a ascese puritana - como toda ascese "racional" trabalhava com o fim de tornar o ser humano capaz de enunciar afirmativamente e fazer valer, em face dos "afetos”, seus "motivos constantes", em particular aqueles que ela mesma lhe "inculcava": - com o fim, portanto, de educa-lo como uma "personalidade", neste sentido da psicologia formal. Poder levar uma vida sempre alerta, consciente, clara, ao contrário do que se fala em muitas das representações populares, era a meta; eliminar a espontaneidade do gozo impulsivo da vida, a missão mais urgente; botar ordem na conduta de vida de seus seguidores, o meio mais importante da ascese. Todos esses pontos de vista, que são decisivos, encontram-se estampados nas regras do monasticismo católico tanto quanto nos princípios de conduta de vida dos calvinistas. Nessa abordagem metódica do ser humano por completo é que moram, num e noutro caso, seu enorme poder de triunfar do mundo e, sua capacidade de assegurar o longo fôlego do protestantismo como ecclesia militans. ${ }^{438}$

Com um propósito bastante semelhante ao do Horkheimer dos anos 1930, é interessante notar que Marcuse retoma à típica ideia protestante de dissociação entre a ação humana e os desígnios divinos e a interpreta como um elemento essencial para se compreender os conceitos modernos de autoridade e de liberdade.

Inicialmente, tais concepções apresentavam traços potencialmente antiautoritários ${ }^{439}$. Em certa medida, o cristão sabe que está acima da lei dos homens, e que a sua essência é inalcançável às figuras de autoridade terrenas. O protestantismo em suas distintas denominações, cuja existência se deu a partir de uma luta contra as autoridades vigentes, necessitava libertar os indivíduo da submissão ao feudalismo tradicional ${ }^{440}$. Todavia, essa disposição é amainada internamente. O funcionamento dessa nascente ordem social é absolutamente dependente de relações de autoridade indecifráveis em sua imediaticidade. Para que o cristão permaneça livre em sua consciência é

438 Ibidem; p. 108-109.

439 É necessário sublinhar que Weber também salientou esse elemento antiautoritário presente na doutrina religiosa dos protestantes. Além da tendência da formação de pequenas seitas, sobretudo, pela desvalorização de qualquer tutela eclesiástica e estatal em questões éticas e de salvação da alma, esse aspecto se fez presente numa polêmica em torno de um decreto do rei Carlos I por meio do qual ficavam permitidas algumas diversões populares aos domingos. Segundo Weber: "E se o rei ameaçava com penas severas cada afronta à legalidade desses esportes, o objetivo era justamente o de romper com esse lance de ascetismo, perigoso para o Estado porque antiautoritário. A sociedade monárquico-feudal defendia os 'desejosos de diversão' contra a moral burguesa emergente e o conventículo ascético hostil à autoridade, assim como hoje a sociedade capitalista costuma proteger os 'desejosos de trabalho' contra a moral de classe dos operários e o sindicalismo hostil à autoridade.” Ibidem; p. 152.

440 Marcuse, Herbert. "Estudo sobre a autoridade e a família”; p. 59. 
necessário que o mundo da concupiscência seja transformado definitivamente no lugar da não-liberdade ${ }^{441}$. O mundo permanecer sob o jugo de processos heterônomos associa-se à moderna concepção de liberdade individual. Em “Estudo sobre a autoridade e a família”:

Somente porque e na medida em que o homem é livre é que ele pode estar em situação de não-liberdade; porque ele "propriamente" (como cristão, como pessoa racional) é inteiramente livre, tem que ser "impropriamente" (como membro do mundo "exterior") não-livre. Com efeito, a completa liberdade do homem também no mundo "exterior" seria por si mesma sua completa libertação de Deus, sua escravização sob o domínio do Diabo. (...). A doutrina cristã da liberdade transfere a libertação do homem para antes de sua história real, para essa doutrina não existe libertação do homem na história, e, ainda mais: uma tal libertação significa para ela, com bons motivos, propriamente algo de negativo, ruim, a saber, a libertação parcial em relação a Deus, o ser livre para praticar o mal (simbolizados no pecado original). ${ }^{442}$

De acordo com Marcuse, os critérios e os discursos fomentadores de juízos racionais sobre o ordenamento social foram retirados da efetividade histórica. Sobretudo a partir de Calvino, o reino da liberdade do cristão - isto é, a interioridade de sua fé e de sua consciência - não é mais entendido como uma esfera contraposta à vida social. A criação do mundo não se pautou pela justiça e pelo amor divino, mas pela majestade e incompreensível sabedoria que exigem uma obediência incondicional e um culto humilde ${ }^{443}$.

O subjacente sistema de autoridade corporificou uma sombra coisificada. Em um mundo concebido como uma ordem dos maus e para os maus, a atividade humana esvazia-se de sentido. Os princípios vigentes de justiça não necessitam de qualquer justificativa racional para serem impostos aos indivíduos. Todo ensaio de questionamento é silenciado na forma de uma submissão necessariamente incondicional. Pois, dado que a sua natureza advém da vontade de um deus transcendente e não em função da maneira pela qual se estabelecem e se reproduzem as relações sociais $^{444}$, a injustiça realmente existente passa a ser encarada como emanação de um desígnio divino ininteligível para a razão humana. Segundo Marcuse:

Contudo, o perigo ameaçava a partir de outra direção. De início, a liberdade incondicional da "pessoa" proclamada por Lutero incentivava, exatamente diante da coisificação da autoridade, por meio da incongruência entre dignidade e mérito do ofício, uma tendência antiautoritária: a falta de sentido "privado" da autoridade do indivíduo

441 Ibidem; p. 57.

442 Ibidem; p. 57-58.

443 Ibidem; p. 72.

444 Ibidem; p. 73. 
burguês. Ainda mais destruidora era a influência da colocação da liberdade cristã e da concepção a ela relacionada de um "reino natural” do amor, igualdade e justiça. Embora estivesse separado por meio de um abismo dos sentidos da ordem social existente, a simples reivindicação e a plena materialidade desse reino eram suficientes para ameaçar a ordem social inteiramente formalizada. As ideias de amor, igualdade e justiça, que ainda se encontravam de forma atuante ainda que esmaecida em Lutero, foram fator constante de intranquilidade para a sociedade burguesa que surgia por sua utilização revolucionária nas revoltas camponesas, associações religiosas e seitas. Uma das contribuição decisivas de Calvino reside no nivelamento das contradições surgidas a este respeito, na inserção dessas tendências destrutivas no seio da ordem social burguesa. É característico o fato de que esse nivelamento só foi possível porque as contradições começaram a irromper em uma nova dimensão - é verdade que agora não mais em um campo transcendente à ordem burguesa como um todo, e sim imanente a ela. ${ }^{445}$

Também para Marcuse é crucial retomar a interpretação weberiana acerca da modificação promovida pelo protestantismo no interior dos laços familiares. Aos olhos puritanos, esse tipo tradicional relacionamento é visto, no mínimo, com desconfiança e alguma reserva. Isso se deve, principalmente, por uma razão dogmática.

Com Lutero, em agudo contraste à vida monástica e seu egoísta desprezo pelas coisas do mundo, o mote cristão do amor ao próximo se expressara exteriormente no desempenho de uma profissão. Calvino transforma radicalmente essa noção. O Pai clemente e misericordioso do Novo Testamento foi obliterado pelo Deus absconditus, a atividade missionária tornou-se um instrumento para espalhar a palavra divina e não para redimir o indivíduo censurado e, consoante esses princípios, a ação prática no mundo referia-se unicamente ao objetivo impessoal de conformar racionalmente o cosmos social, sem qualquer intenção de aumentar a glória da criatura ${ }^{446}$.

Pois, partilhada somente por um número desconhecido e imutável de eleitos, a graça divina é uma condição rigorosamente individual. Nenhum tipo de organização social existente na terra é capaz de espelhar a verdadeira comunidade dos santos. A disposição dos ungidos ante os condenados é idêntica sejam eles cidadãos de uma nação distante ou membros de sua própria família. A fúria contra o pecado continua a não resvalar no pecador, porém este já não é mais visto com olhos piedosos e complacentes, mas por uma desaventurada indiferença e uma desdita impessoalidade. Segundo Weber:

Quem quiser sentir os efeitos específicos dessa atmosfera peculiar confira, neste que

445 Ibidem; p. 70.

446 Ibidem; p. 99. 
de longe é o livro mais lido de toda literatura puritana, Pilgrim's Progress, de Bunyan, a descrição do comportamento do protagonista Christian após tomar consciência de que se encontra na "cidade da perdição" e ser então surpreendido por um chamamento que o conclama a sair sem demora em peregrinação à cidade celestial. A mulher e os filhos agarram-se a ele - mas ele, tapando os ouvidos com os dedos, vai em frente gritando "Vida, vida eterna!” [“Life, eternal life!”] Não há refinamento literário capaz de reproduzir melhor que a sensibilidade ingênua desse latoeiro - que se mete a escrever em versos na prisão e colhe o aplauso de um mundo inteiro [de crentes] - o estado de espírito do crente puritano que no fundo só se ocupa consigo mesmo e só pensa na própria salvação, conforme se vê pelos diálogos edificantes que no caminho ele trava com outros peregrinos movidos pela mesma ambição e que lembra [mais ou menos] os Gerechter Kammacher de Gottfried Keller. É só quando já está salvo que lhe ocorre a ideia de que seria bom ter a família junto de $\mathrm{si}^{447}$

Assim, ao se introduzir essa disposição da ética protestante nas relações pessoais e nos vínculos familiares, o cálculo racional corroeu as antigas relações de piedade. Para Marcuse, isso significa, ao mesmo tempo, um fortalecimento e um enfraquecimento das figuras de autoridade mundanas. Como já foi dito, o seu poder de mando é agora inquestionado, pois ele se assenta sobre a própria vontade divina. Porém, o conteúdo de suas ordens não é mais formulado pela razão humana e sim lhes é ditado de forma heterônoma. No interior das famílias, por exemplo, o poder paterno perde a sua antiga ingenuidade e torna-se, cada vez mais, uma autoridade planificada e criada artificialmente ${ }^{448}$. Segundo Marcuse:

Com a independentização e coisificação da autoridade terrena, a violação da autoridade, a sublevação e a desobediência se tornam pecado social em geral, "pecados maiores que o assassinato, a incastidade, o roubo, o engodo e tudo o mais que possa ser concebido neste sentido”. (...). A fundamentação que Lutero apresenta para essa condenação demoníaca da revolta revela um dos pontos centrais do mecanismo social. Enquanto que todos os outros males se referem apenas a "partes" do todo, a revolta "atinge a própria cabeça”. O roubo e o assassinato deixam subsistir a cabeça que pode castiga-los, persistindo, portanto, a possibilidade do castigo; a revolta, porém, “atinge o próprio castigo" e, com isso, "não apenas tal ou qual aspecto da ordem, as a própria ordem existente”, que se baseia essencialmente na possibilidade de castigar, no reconhecimento de sua autoridade. "O asno quer sofrer pancadas, e a população quer ser governada pela violência; Deus sabia perfeitamente disso. Por isso, ele deu à autoridade não um rabo de raposa e sim a espada." 449

Porém, isso ainda não é suficiente. Não se trata meramente de uma defesa da ordem social

447 Ibidem; p. 97-98.

448 De maneira geral, a transformação do papel da autoridade paterna no interior da família burguesa é uma das grandes preocupações partilhadas por vários dos autores pertencentes ao Instituto de Pesquisa Social, sobretudo durante a década de 1930. Segundo Martin Jay: “Os três ensaios da parte teórica foram preparados de maneira coordenada. Todos afirmaram a irracionalidade crescente da ordem social e o declínio concomitante da autoridade racional, fosse ela política ou de outra natureza. Todos expressaram, por outro lado, certa confiança na possibilidade de uma ordem social em que fosse possível conciliar a autoridade geral e o interesse particular. Por último, todos compartilharam a consternação, enunciada de maneira mais eloquente no ensaio de Horkheimer, com o fato de a família estar deixando rapidamente de ser um agente dessa possibilidade.” Jay, Martin. A imaginação dialética; p. 181-182.

449 Marcuse, Herbert. “Estudo sobre a autoridade e a família”; p. 69. 
que se impõe do exterior - tal configuração é responsável pela formação subjetiva da individualidade como a conhecemos. Fazendo uso de conceitos freudianos, Marcuse afirma que a história do homem é indissociável da história de sua repressão e, a fim de cumprir esse objetivo, a cultura e a civilização coagem não somente a sua existência social como também a biológica. O preço da formação do Eu auto-idêntico é a postergação da satisfação integral de suas pulsões. Os sujeitos deixam de se orientar unicamente consoante o princípio de prazer e já não mais se organizam como um feixe de instintos animais. Por um lado, pela atuação do princípio de realidade, o ser humano desenvolve a função da razão, torna-se capaz de examinar a realidade, distinguir entre o bom e o mau, o verdadeiro e o falso e, finalmente, surge como um ser consciente e adquire as faculdades da atenção, da memória e do discernimento.

Por outro, no entanto, a teoria psicanalítica ensina que não há apenas um adiamento da satisfação das pulsões, mas uma verdadeira transubstanciação do próprio prazer e dos desejos. Como um trauma que se atualiza e se repõe historicamente, a vida sociocultural impõe continuamente suas restrições, vinculando a civilização à barbárie, o progresso ao sofrimento e a liberdade à infelicidade. Quando a carência e a não satisfação das necessidades humanas se revelam resultado de uma forma específica de organizar a vida social e não mais como consequência natural da luta pela existência num mundo demasiado pobre, a distribuição da escassez e dos esforços para superá-la - isto é, o trabalho - só se torna compreensível quando se observa a sua estreita ligação com a racionalidade da dominação. Em Eros e civilização:

\footnotetext{
A repressão é um fenômeno histórico. A subjugação efetiva dos instintos, mediante controles repressivos, não é imposta pela natureza, mas pelo homem. O pai primordial, como arquétipo da dominação, inicia a reação em cadeia de escravização, rebelião e dominação reforçada, que caracteriza a história da civilização. Mas, desde a primeira e pré-histórica restauração da dominação, após a primeira rebelião contra esta, a repressão externa foi sempre apoiada pela repressão interna: o indivíduo escravizado introjeta seus senhores e suas ordens no próprio aparelho mental. A luta contra a liberdade reproduz-se na psique do homem, como a auto-repressão do indivíduo reprimido, e a sua auto-repressão apoia, por seu turno, os senhores e suas instituições. ${ }^{450}$
}

Dessa forma, ante uma sociedade afluente que já não mais sofre as restrições de escassez material, essa relação necessita ser pensada a partir de outra perspectiva. Já não há razoabilidade 450 Idem. Eros e civilização; p. 36-37. 
alguma em postergar a satisfação das pulsões individuais de modo tão severo. Para Marcuse, as sociedades industriais avançadas põem em circulação uma carga maior e irracional de repressão. O princípio de desempenho - a forma histórica predominante do princípio de realidade ${ }^{451}$ - e a mais-repressão oprimem o desenvolvimento autônomo das pulsões individuais e as congelam num estágio anterior às possibilidades sócio-históricas disponíveis. As instâncias do Eu e do Supereu agridem o inconsciente e mantém o homem civilizado preso a uma psique obsoleta e não condizente com o grau que se poderia atingir de maturidade individual e social ${ }^{452}$. O resultado mais evidente é a organização repressiva da sexualidade. O processo que se desencadeia submete as pulsões sexuais à primazia de sua função procriadora e, com isso, transforma-se a própria natureza da sexualidade - o que poderia ser vivenciado como um princípio autônomo que governa todo o organismo converte-se em uma especializada e temporária, isto é, em um meio para se atingir um determinado fim utilitário $^{453}$. Segundo Marcuse:

Contudo - e este ponto é decisivo - a energia instintiva assim retraída não se acumula (insublimada) nos instintos agressivos, porque a sua utilização social (no trabalho) sustenta e até enriquece a vida do indivíduo. As restrições impostas à libido parecem tanto mais racionais quanto mais universais se tornam, quanto mais impregnam a sociedade como um todo. Atuam sobre o indivíduo como leis objetivas externas e como uma força internalizada: a autoridade social é absorvida na "consciência" e no inconsciente do indivíduo, operando como seu próprio desejo, sua moralidade e satisfação. No desenvolvimento "normal”, o indivíduo vive a sua repressão "livremente” como sua própria vida: deseja o que se supõe que ele deve desejar; suas gratificações são lucrativas para ele e para os outros; é razoavelmente e, muitas vezes, exuberantemente feliz. Essa felicidade, que ocorre fracionadamente, durante as poucas horas de lazer entre os dias ou noites de trabalho, habilita-o a prosseguir em seu desempenho, que por sua vez perpetua o seu trabalho e o dos outros. Seu desempenho erótico é posto em alinhamento com o seu desempenho social. A repressão desaparece na esplêndida ordem objetiva das coisas, que recompensa mais ou menos adequadamente os indivíduos cumpridores e obedientes, e que, ao fazê-lo, reproduz de modo mais ou menos adequado a sociedade como um todo. ${ }^{454}$

Convém analisar alguns elementos da interpretação weberiana sobre as tensões existentes entre a racionalização desencadeada pelas religiões de salvação e o maior poder irracional da vida, isto é, o amor sexual ${ }^{455}$. De acordo com Weber, sempre que uma ética da fraternidade desenvolvida se encontra com uma sexualidade sublimada, essa relação se torna tanto mais complexa e a

451 Ibidem; p. 51.

452 Ibidem; p. 49.

453 Ibidem; p. 55.

454 Ibidem; p. 59.

455 Weber, Max. “Consideração intermediária”; p. 339. 
rivalidade entre elas se agudiza exponencialmente. No ocidente, antes de desembocar no moderno ascetismo intramundano, a primitiva proximidade entre as relações sexuais e os rituais sagrados sofreu algumas inflexões significativas. O erotismo que se condensa na sublime esfera do que é cultivada conscientemente ${ }^{456}$ confrontou-se com o romantismo cavalheiresco da Grécia Antiga, onde os motivos trágicos do amor carnal eram vistos como um autêntico poder do destino. Posteriormente, o simbolismo próprio às relações de vassalagem da Idade Média pretendeu transformar as relações eroticamente sublimadas a partir de um código de honra entre os homens - a figura dama a ser cortejada se constituía em função desse compromisso firmado por cavalheiros. Finalmente, nas culturas intelectualistas, a vida sexual apresentou-se como uma ameaça ao prometer realizar na terra o objetivo de toda ideia de salvação religiosa - a mútua penetração das almas.

No entanto, malgrado suas especificidades históricas, as distintas maneiras de apaziguar as relações entre a esfera da sexualidade e os processos de racionalização social recorreram a uma estratégia que se consolidou ao longo dos séculos. Esses esforços podem ser resumidos por meio das tentativas de canalizar o desatino da sexualidade em algo que seja socialmente útil ou, ao menos, que não rompa os vínculos sociais existentes. Em “Consideração intermediária”:

\begin{abstract}
A ascese racional no seio do mundo (ascese da profissão) apenas pode aceitar o casamento racionalmente regulamentado como sendo uma das ordens divinas preparadas para a criatura desesperadamente corrompida pela "concupiscência"; no âmbito dessa ordem, e somente nele, trata-se de viver em conformidade com os respectivos fins racionais: a geração e a educação dos filhos, assim como a ajuda mútua em estado de graça. Qualquer refinamento tendente para o erotismo tem de ser rejeitado por essa ascese como uma deificação da criatura, e da pior espécie. Por seu lado, inclui precisamente a sexualidade genuinamente natural, não sublimada, porque rústica, numa ordem racional da criação; mas, então, todos os elementos constitutivos da "paixão" são considerados como resíduos do pecado original, perante os quais, segundo Lutero, Deus "finge não ver", para evitar algo ainda pior. A ascese racional extramundana (ascese monástica activa) também os repudia, e, juntamente com eles, tudo quanto seja sexual, como representando um poder diabólico que põe em perigo a salvação. ${ }^{457}$
\end{abstract}

Essa tensão entre os vínculos de uma ética fraternal racional e a irracionalidade da esfera erótica pode encontrar outro desfecho ${ }^{458}$. Contra a perpetuação desse custoso arranjo, o pensamento

456 Ibidem; p. 341.

457 Ibidem; p. 346-347.

458 Embora ainda me falte maiores referências para uma contraposição mais detida com os argumentos de Marcuse, o próprio Weber parece ensaiar a elaboração acerca do erotismo que pode ser pensada como uma aposta utópica para uma ética que já não se paute pelos princípios da racionalidade ocidental. Segundo Weber: "Nenhuma comunhão erótica plena se reconhecerá senão como fundada por uma misteriosa destinação recíproca - ou seja, destino no 
é capaz de formular juízos críticos que não só o desnaturaliza como também consegue perceber tendências sociais incrustadas em seus conceitos que apontam para um desenlace qualitativamente distinto. Para Marcuse, as modernas sociedades capitalistas permitem uma saída que alteraria substancialmente a relação dos homens com seus desejos e a própria concepção da razão. Tudo o que fora reprimido e relegado ao inconsciente vinga-se do seu agressor e fundamenta a possibilidade de um mundo melhor - isto é, uma nova relação entre as pulsões e a razão ${ }^{459}$. A sexualidade, a mais desordenada de todas as pulsões, pode promover um progresso verdadeiro rumo a formas superiores de liberdade civilizada. O antigo corpo moldado apenas pelos critérios socialmente úteis e restringido em sua plenitude pela reprodução monogâmica e pelos tabus sobre as perversões mostrar-se-ia em sua dignidade preservada e, finalmente, apto para uma felicidade verdadeira.

A condição para isso é a transformação do próprio trabalho. Quando já não for mais alienado, o trabalho pode compor um princípio de realidade que não seja mais repressivo. Caso seja possível realmente revolucionar os pressupostos da atividade humana - a fim de que ela não seja mais concebida como uma tarefa socialmente útil, orientada conforme critérios de produtividade e de desempenho -, o trabalho se transformará na transparente satisfação de uma necessidade individual $^{460}$. Segundo Marcuse:

A relegação de possibilidades reais para a "terra de ninguém” da utopia constitui, só por si, um elemento essencial da ideologia do princípio de desempenho. Se a construção de

sentido mais elevado da palavra - e, por isso, 'legitimada' (nem sentido completamente alheio à ética). Mas, para a religião de redenção, esse ‘destino’ nada mais é que o mero acaso da paixão que se inflama. A obsessão patológica assim instaurada, a idiossincrasia, a modificação da intuição empírica e de toda a equidade objetiva têm, forçosamente, que se lhe afigurar como a mais completa renegação de todo o amor fraterno e da sujeição a Deus. Sentindo-se como 'bondade', a euforia do amante feliz, com a sua amável necessidade de atribuir também expressões fisionómicas alegres a toda a gente ou, num ingénuo empenho em fazer a felicidade de outrem, de as obter por encanto, depara sempre, por isso, com o frio escárnio da ética da fraternidade radical, genuinamente fundamentada no plano religioso (o que se encontra, por exemplo, nas passagens psicologicamente mais coerentes das obras de juventude de Tolstoi)”. Ibidem; p. 345-346. Sobre esse trecho, segundo Pierucci: “Aos olhos de Weber, a possibilidade de reencantar parece pois que não está no alardeado 'retorno do sagrado', como andam dizendo, querendo e torcendo, quando não comemorando, tantos sociólogos religiosos da religião que conhecemos. (...). A crer em sua Consideração intermediária, o locus da existência humana em que se esgueira uma possibilidade efetiva de encantar novamente o mundo não é a esfera religiosa, mas uma outra esfera cultural, ao mesmo tempo não-religiosa e não-racional: a esfera erótica, onde reina, segundo Weber, 'a potência mais irracional da vida’ - o amor sexual.” Pierucci, Antônio Flávio. O desencantamento do mundo; p. 221.

459 Marcuse, Herbert. Eros e civilização; p. 174.

460 Ibidem; p. 183. 
um desenvolvimento instintivo não-repressivo se orientar, não pelo passado pré-histórico, mas pelo presente histórico e a civilização madura, a própria noção de utopia perde o seu significado. A negação do princípio de desempenho emerge não contra, mas com o progresso da racionalidade consciente; pressupõe a mais alta maturidade da civilização. As próprias realizações do princípio de desempenho intensificaram a discrepância entre os processos do inconsciente arcaico e da consciência do homem, por uma parte, e as suas potencialidades concretas, por outra. A história da humanidade parece tender para outro ponto culminante na vicissitude dos instintos. E à semelhança dos anteriores momentos cruciais, a adaptação da estrutura mental arcaica ao novo meio significaria outra “catástrofe” - uma transformação explosiva no próprio meio. (...). O ator, nesse evento, já não mais seria o homem animal histórico, mas o sujeito consciente, racional, que dominou e se apropriou do mundo objetivo como arena para as suas realizações. ${ }^{461}$

Contudo, são tendências opostas as que têm prevalecido no Ocidente. O sistema produtivo se mantém bastante distante de qualquer possibilidade de reconstrução que aponte para além da dominação e da exploração econômica, porque a base psíquica que se organiza em torno do ascetismo intramundano persiste como o fundamento da subjetividade nas sociedades industriais avançadas $^{462}$. Porém, de acordo com Marcuse, parece haver uma diferença fundamental entre o seu passado puritano e o seu atual momento histórico. A fim de se comportarem conforme os ditames divinos, os protestantes se viam obrigados a suportar uma rotina de árduo esforço físico e mental e de um amplo e exigente conjunto de privações. Talvez também naquele período a quantidade de trabalho realizado já fosse maior do que o tecnicamente requerido e o adiamento dos desejos se prolongava para muito além do socialmente necessário. De qualquer forma, os indivíduos que se submetiam aos rigores dessas abstinências não corriam atrás de recompensas e nem pretendiam se satisfazer sua libido com o pouco que recebiam. A atitude deles era de negar firmemente todo gozo impulsivo na vida.

No entanto, entre outros fatores, o que individualiza e distingue o capitalismo avançado de seu predecessor reside na peculiaridade da maneira pela qual os indivíduos se portam diante das restrições que caracterizam suas vidas. Eles não apenas aturam um fatigante cotidiano e suportam uma virulenta repressão de suas pulsões, mas parecem cada vez mais desejarem e se satisfazerem com isso. A mesma estrutura psíquica repressiva persiste em uma sociedade que já não mais sofre com as privações de etapas anteriores da civilização ocidental. Segundo Marcuse:

461 Ibidem; p. 139-140.

462 Ibidem; p. 15. 
A dessublimação institucionalizada parece, assim, ser um aspecto da “conquista da transcendência” conseguida pela sociedade unidimensional. Assim como essa sociedade tende a reduzir e até a absorver a oposição (a diferença qualitativa!) no âmbito da política e da cultura superior, também tende a fazê-lo na esfera instintiva. O resultado é a atrofia dos órgãos mentais, impedindo-os de perceber as contradições e alternativas e, na única dimensão restante da racionalidade tecnológica, prevalece a Consciência Feliz.

Ela reflete a crença em que o real seja racional e em que o sistema estabelecido a despeito de tudo entrega as mercadorias. As pessoas são levadas a ver no aparato produtivo o agente eficaz de pensamento e ação ao qual se devem render seu pensamento e ação pessoais. E, nessa transferência, o aparato também assume o papel de agente moral. A consciência é absolvida por espoliação, pela necessidade geral de coisas. ${ }^{463}$

463 Idem. A ideologia da sociedade industrial; p. 88. 


\section{Referências bibliográficas.}

ADORNO, Theodor. "Capitalismo tardio ou sociedade industrial?". In: Cohn, Gabriel (org.). Theodor W. Adorno. Sociologia. São Paulo: Editora Ática, 1994.

. Dialética negativa. Rio de Janeiro: Jorge Zahar Editor, 2009.

. “Introdução à controvérsia sobre o positivismo na sociologia alemã”. . Introdução à sociologia (1968). São Paulo: Editora UNESP, 2008.

. Philosophische Elemente einer Theorie der Gesellschaft. 2006.

. “Notas marginais sobre teoria e práxis”. Palavras e sinais. Modelos críticos

2. Petrópolis: Vozes, 1995.

. "Sobre a lógica das ciências sociais". In: Cohn, Gabriel (org.). Theodor W.

Adorno. Sociologia. São Paulo: Editora Ática, 1994.

ANTUNES, Ricardo \& LEÃO RÊGO, Walquiria (org.). Lukács: um Galileu no século XX.

São Paulo: Boitempo editorial, 1996.

ARATO, Andrew. “Lukács” theory of reification”. In: Telos, nº 11, 1972.

ARATO, Andrew \& BREINES, Paul. The Young Lukács and the origins of Western

Marxism. New York: Pluto Press, 1979.

BENHABIB, Seyla. “A crítica da razão instrumental”. In: ZIZEK, Slavoj (org.). Um Mapa

da Ideologia. Rio de Janeiro: Contraponto, 1996.

BOGNER, Artur. Zivilisation und Rationalisierung. Die Zivilisationstheorien M.

Webers, N. Elias' und der Frankfurter Schule im Vergleich. Opladen: Westdt. Verlag, 1989.

BÖHME, Hartmut. Fetischismus und Kultur. Eine andere Theorie der Moderne. Hamburg: Rowohlt Verlag, 2012.

BRONNER, Stephen e KELLNER, Douglas (orgs.). Critical theory and society. A reader.

London: Routledge, 1989. 
CARNEIRO, Silvio. O discurso ontológico e a teoria crítica de Herbert Marcuse. Gênese da filosofia da psicanálise (1927-1955). São Paulo: Dissertação de Mestrado - USP; 2008.

COHN, Gabriel. "A sociologia como ciência impura". In: ADORNO, Theodor. Introdução à sociologia (1968). São Paulo: Editora UNESP, 2008. . Crítica e resignação. Max Weber e a teoria social. São Paulo: Martins Fontes, 2003. . “Introdução”. In: COHN, Gabriel (org.). Max Weber: sociologia. São Paulo:

Editora Ática, 2003.

DAHMS, Hans-Joachim. Positivismusstreit. Die Auseinandersetzungen der Frankfurter Schule mit dem logischen Positivismus, dem amerikanischen Pragmatismus und dem kritischen Rationalismus. Frankfurt am Main: Suhrkamp, 1994.

BRAUNSTEIN, Dirk. Adornos Kritik der politischen Ökonomie. Frankfurt am Main: Transcript Verlag, 2011.

DUBIEL, Helmut. Kritische Theorie der Gesellschaft. Eine einführende Rekonstruktion von den Anfängen im Horkheimer-Kreis bis Habermas. München: Juventa Verlag, 1992 Wissenschaftsorganisation und politischen Erfahrung. Studien zur

Kritischen Theorie. Frankfurt am Main: Suhrkampf, 1978.

FEENBERG, Andrew. Lukács, Marx and the sources of critical theory. New York: Oxford University Press, 1986.

GATTI, Luciano. Constelações. Crítica e verdade em Benjamin e Adorno. São Paulo: Edições Loyola, 2009.

HEARN, Francis. “The dialectical use of ideal types”. In: Theory and Society, Vol. 2, n ${ }^{\circ}$ 4, 1975.

HONNETH, Axel. "A Physiognomy of the Capitalist Form of Life: A Sketch of Adorno’s Social Theory". In: Constellations, Vol. 12, n 1, 2005. 
Frankfurt am Main: Suhrkampf, 2008.

HORKHEIMER, Max. “Autorität und Familie”. In: SCHMIDT, Alfred (org.).

Max Horkheimer. Gesammelte Schriften. Band 3: Schriften 1931 - 1936. Frankfurt am Main: Fischer Taschenbuch Verlag, 2009.

. Eclipse da razão. São Paulo: Editora Centauro, 2002.

. Teoria crítica: uma documentação. Tomo 1. São Paulo: Editora Perspectiva,

1990.

• “Teoria Tradicional e Teoria Crítica”. In: ADORNO, Theodor \&

HORKHEIMER, Max. Textos Escolhidos. São Paulo: Editora Nova Cultural, 1991.

. “Zum Problem der Voraussage in den Sozialwissenschaft”. SCHMIDT, Alfred

(org.). Max Horkheimer. Gesammelte Schriften. Band 3: Schriften 1931 - 1936. Frankfurt am

Main: Fischer Taschenbuch Verlag, 2009.

JAY, Martin. A imaginação dialética. História da Escola de Frankfurt e do Instituto de

Pesquisas Sociais 1923-1950. Rio de Janeiro: Contraponto, 2003.

. Marxism and totality. The adventures of a concept from Lukács to

Habermas. Berkeley - Los Angeles: University of California Press, 1984.

KELLNER, Douglas. Critical theory, marxism and modernity. Baltimore: The John Hopkins University Press, 1989.

. Herbert Marcuse and the crisis of Marxism. Los Angeles: University of

California Press, 1984.

. “Tecnologia, guerra e fascismo: Marcuse nos anos 40. In: KELLNER,

Douglas. Tecnologia, guerra e fascismo. Coletânea de artigos de Herbert Marcuse. São Paulo:

Editora Unesp, 1999.

KLEIN, Stefan Fornos. A universidade e a sociologia segundo Max Horkheimer: teoria, 
pesquisa e crítica. Tese de Doutorado. São Paulo: Universidade de São Paulo, 2012.

. Sobre a dominação e a emancipação na teoria crítica de Herbert Marcuse.

Dissertação de mestrado. São Paulo: Universidade de São Paulo, 2006.

LÖWY, Michael. “Figures of Weberian Marxism”. In: Theory and Society, vol. 25, $n^{\circ}$ 3, 1996.

. Para uma sociologia dos intelectuais revolucionários. A evolução política de Lukács (1909-1929). São Paulo: Lech Livraria, 1979.

. Romantismo e messianismo. Ensaios sobre Lukács e Benjamin. São Paulo:

Editora Perspectiva, 1990.

LUKÁCS, Georg. História e consciência de classe. Estudos sobre a dialética marxista. São Paulo: Martins Fontes, 2003.

LUTZ-BACHMANN, Matthias. "Humanität und Religion. Zu Max Horkheimers Deutung des Christentums”. In: SCHMIDT, Alfred \& ALTWICKER, Norbert (orgs.). Max Horkheimer heute: Werk und Wirkung. Frankfurt am Main: Fischer Taschenbuch Verlag, 1986.

MAAR, Wolfgang Leo. “A perspectiva dialética em Adorno e a controvérsia com Habermas”. In: Revista Trans/Form/Ação, .

MARX, Karl e ENGELS, Friedrich. A ideologia alemã. São Paulo: Boitempo editorial, 2007. . "Manifesto do partido comunista”. In: Estudos Avançados, vol. 12, n 34, 1998.

MERLEAU-PONTY, Maurice. As aventuras da dialética. São Paulo: Martins Fontes, 2006.

MITZMAN, Arthur. The iron cage. Na historical interpretation of Max Weber. New Jersey: Transaction books, 2005.

MOMMSEN, Wolfgang. Max Weber and German politics 1890-1920. Chicago: The 
University of Chicago Press, 1990.

. The age of bureaucracy. New York: Harper \& Row, 1974.

. The political and social theory of Max Weber. Cambridge: Polity Press,

2007.

MÜLLER-DOOHM, Stefan. Adorno. A biography. Cambridge: Polity Press, 2005.

MUSSE, Ricardo. De socialismo científico a teoria crítica. Modificações na autocompreensão do marxismo entre 1878 a 1937. Tese de doutorado - filosofia. São Paulo: Universidade de São Paulo, 1997.

."Marxismo: ciência revolucionária ou teoria crítica?”. In: ANTUNES, Ricardo

\& LEÃO REGO, Walquiria (orgs.). Lukács: um Galileu no Século XX. São Paulo: Boitempo Editorial, 1996.

NOBRE, Marcos. Lukács e os limites da reificação. Um estudo sobre História e consciência de classe. São Paulo: Editora 34, 2001.

PICCONE, Paul. “Dialectic and materialism in Lukács”. In: Telos, n 11, 1972.

PISSARDO, Carlos Henrique. Os pressupostos materialistas da crítica à razão cognitiva na Dialética do Esclarecimento. Dissertação de mestrado - Filosofia. São Paulo: Universidade de São Paulo, 2011.

PIERUCCI, Antônio Flávio. O desencantamento do mundo. Todos os passos do conceito de Max Weber. São Paulo: Editora 34, 2003.

ROSE, Gillian. Hegel contra sociology. London - New York: Verso, 2009.

. The melancholy science. An introduction to the thought of Theodor W.

Adorno. London: The Macmillan Press, 1978.

SCHECTER, Darrow. The critique of instrumental reason from Weber to Habermas. London: Continuum books, 2010.

SCHNÄDELBACH, Herbert. Philosophie in Deutschland. 1831-1933. Franfurt am Main: 
Suhrkamp, 1983.

SCHMIDT, Alfred. “Aufklärung und Mythos im Werk Max Horkheimers.” In: SCHMIDT, Alfred \& ALTWICKER, Norbert (orgs.). Max Horkheimer heute: Werk und Wirkung. Frankfurt am Main: Fischer Taschenbuch Verlag, 1986.

. Drei Studien über Materialismus. Schopenhauer, Horkheimer, Glücksproblem. München: Carl Hanser Verlag, 1977.

Zur Idee der Kristischen Theorie. Elemente der Philosophie Max Horkheimers. Frankfurt am Main: Ullstein, 1979.

SCHLUCHTER, Wolfgang. Aspekte bürokratischer Herrschaft. Frankfurt am Main: Suhrkamp, 1985.

. Rationalismus der Weltbeherrschung. Studien zu Max Weber. Frankfurt am Main: Suhrkamp, 1980.

. Religion und Lebensführung. Band 1. Studien zu Max Webers Kulturund Werttheorie. Frankfurt am Main: Suhrkamp, 1991.

Religion und Lebensführung. Band 2. Studien zu Max Webers Religionsund Herrschaftssoziologie. Frankfurt am Main: Suhrkamp, 1991.

. The rise of western rationalism. California: California University Press, 1985.

SÖLLNER, Alfred. Geschichte und Herrschaft. Studien zur materialistischen Sozialwissenschaft. 1929-1942. Franfurt am Main: Suhrkamp, 1979.

STAMMER, Otto (org.). Max Weber and sociology today. New York: Harper \& Row, 1971.

STEINERT, Henz. Max Webers unwiderlegbare Fehlkonstruktionen. Die protestantische Ethik und der Geist des Kapitalismus. Frankfurt am Main: Campus Verlag, 2010. 
TARR, Zoltán. “A note on Weber and Lukács”. In: International Journal of Politics, Culture and Society, vol. 3, $\mathrm{n}^{\circ} 1,1989$.

. The Frankfurt School. The critical theories of Max Horkheimer and

Theodor Adorno. New York: Transaction Pub, 2011.

TAUBES, Jacob. “Kultur und Ideologie”. In: ADORNO, Theodor (org.). Spätkapitalismus oder Industriegesellschaft? Stuttgart: F. Enker Verlag, 1969.

TEIXEIRA, Mariana Oliveira do Nascimento. Razão e reificação. Um estudo sobre Max Weber em História e Consciência de Classe de Georg Lukács. Dissertação de mestrado. Campinas: Unicamp, 2010.

TURNER, Stephen e FACTOR, Regis. “Objetive possibility and adequate causation in Weber's methodological writings”. In: Sociological Review, vol. 29, nº 1, 1981.

VANDENBERGHE, Frédéric. A philosophical history of german sociology. London: New York: Routledge, 2009.

VASCONCELLOS, Caio. "O Moloch do presente". Adorno e a crítica à sociologia. São Paulo: Alameda Editorial, 2012.

WAIZBORT, Leopoldo. “Introdução”. In: WEBER, Max. Os fundamentos racionais e sociológicos da música. São Paulo: Edusp, 1995.

WEBER, Max. A ética protestante e o "espírito” do capitalismo. São Paulo: Companhia das Letras, 2004.

. A “objetividade” do conhecimento nas ciências sociais. São Paulo: Editora Ática, 2006.

. A sociologia das religiões. Lisboa: Relógio D’Água Editores, 2006.

. "Ciência como vocação". In: BOTELHO, André (org.). Essencial sociologia.

São Paulo: Companhia das Letras, 2013.

Economia e sociedade. Fundamentos da sociologia compreensiva. Volumes 
1 e 2. São Paulo: Editora UnB, 2004.

“Einleitung”. In: WEBER, Max. Gesammelte Aufsätze zur

Religionssoziologie. Band I.

. “Introdução do Autor”. In: WEBER, Max. A ética protestante e o espírito do capitalismo. São Paulo: Editora Pioneira Thomson Learning, 2001.

. “O Estado nacional e a política econômica”. In: COHN, Gabriel (org.). Weber.

Sociologia. São Paulo: Editora Ática, 1997.

. Os fundamentos racionais e sociológicos da música. São Paulo: Edusp, 1995.

. “Os três tipos puros de dominação legítima”. In: COHN, Gabriel (org.).

Weber. Sociologia. São Paulo: Editora Ática, 1997.

. “O socialismo”. In: Gertz, R. (org.). Max Weber \& Karl Marx. São Paulo:

Editora Hucitec, 1997.

. "Parlamentarismo e governo numa Alemanha reconstruída”. In: WEBER, Max. Os pensadores. São Paulo: Abril Cultural, 1974.

. "Reflexão intermediária - Teoria dos níveis e direções da rejeição religiosa do mundo". In: BOTELHO, André (org.). Essencial sociologia. São Paulo: Companhia das Letras, 2013.

WHEATLAND, Thomas. The Frankfurt School in Exile. Minneapolis: University Minnesota Press, 2009.

WIGGERSHAUS, Rolf. A escola de Frankfurt. História, desenvolvimento teórico, significação política. Rio de Janeiro: Difel, 2006. 